\title{
ORNL/TM-13532
}

\section{Implementation of Deep Soil Mixing at the Kansas City Plant}

\author{
F. G. Gardner \\ N. Korte \\ J. Strong-Gunderson \\ R. L. Siegrist \\ O. R. West \\ S. R. Cline \\ J. Baker
}

\section{MASTER}

$1 \sqrt{5 T}$

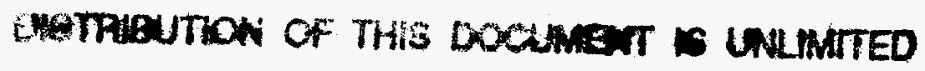

WANAGED AND OPERATED BY LOCKIEEO MARTW ENERGY RESEARCI CORPORATION FOR THE URTED STATES DEPARTUENT OF ENERGY 


\section{DISCLAIMER}

This report was prepared as an account of work sponsored by an agency of the United States Government. Neither the United States Government nor any agency thereof, nor any of their employees, makes any warranty, express or implied, or assumes any legal liability or responsibility for the accuracy, completeness, or usefulness of any information, apparatus, product, or process disclosed, or represents that its use would not infringe privately owned rights. Reference herein to any specific commercial product, process, or service by trade name, trademark, manufacturer, or otherwise does not necessarily constitute or imply its endorsement, recommendation, or favoring by the United States Government or any agency thereof. The views and opinions of authors expressed herein do not necessarily state or reflect those of the United States Government or any agency thereof. 


\section{DISCLAIMER}

Portions of this document may be illegible in electronic image products. Images are produced from the best available original document. 
ORNL/TM-13532

\title{
Implementation of Deep Soil Mixing at the Kansas City Plant
}

\author{
F. G. Gardner ${ }^{1}$ \\ N. Korte ${ }^{2}$ \\ J. Strong-Gunderson ${ }^{3}$ \\ R. L. Siegrist ${ }^{3}$ \\ O. R. West ${ }^{3}$ \\ S. R. Cline ${ }^{3}$ \\ J. Baker ${ }^{4}$
}

For Environmental Restoration Program

at the

Kansas City Plant

U.S. Department of Energy

Kansas City, Missouri

Prepared by:

Oak Ridge National Laboratory

Environmental Technology Section

Grand Junction, Colorado 81502

Managed by:

LOCKFEED MARTIN ENERGY RESEARCH CORPORATION

for the

U.S. DEPARTMENT OF ENERGY

Under Contract \#DE-AC05-960R22464

\footnotetext{
${ }^{1}$ Life Sciences Division, Oak Ridge National Laboratory, Grand Junction, Colorado 81503

${ }^{2}$ Environmental Sc ences Division, Oak Ridge National Laboratory, Grand Junction, Colorado 81503

${ }^{3}$ Environmental Scences Division, Oak Ridge National Laboratory, Oak Ridge, Tennessee 37831

${ }^{4}$ AlliedSignal, Inc., Kansas City, Missouri 64131
} 


\section{Contents}

Figures $\ldots \ldots \ldots \ldots \ldots \ldots \ldots \ldots \ldots \ldots \ldots \ldots \ldots \ldots$ iv

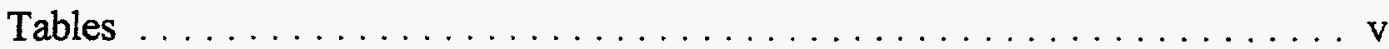

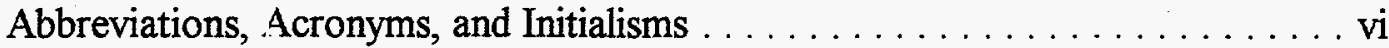

Executive Summary . . . . . . . . . . . . . . . . . . . . . . .

1. INTRODUCTION ........................ 1-1

1.1 Project Description . . . . . . . . . . . . . . . . . . . . 1-1

1.2 Site Background Information $\ldots \ldots \ldots \ldots \ldots \ldots \ldots . \ldots \ldots$ 1-6

1.2 .1 Stratigraphy $\ldots \ldots \ldots \ldots \ldots \ldots \ldots \ldots \ldots \ldots \ldots \ldots \ldots$

1.2.2 Jescription of Contamination . . . . . . . . . . . 1-9

1.3 Process Operations . . . . . . . . . . . . . . . . . . . . . . . . . . 1-9

1.3 .1 Site Preparation ... . . . . . . . . . . . . . . . . 1-9

1.3 .2 Permitting Requirements . . . . . . . . . . . . . . . . . 1-9

1.3.3 DSM Equipment Description . . . . . . . . . . . . . . 1-10

1.3.4 Shakedown/DSM Operational Concerns . . . . . . . . . 1-10

2. INVESTIGATIVE METHODS ................. 2-1

2.1 Soil Saunpling . . . . . . . . . . . . . . . . . . . . 2-1

2.2 Groundwater Sampling . . . . . . . . . . . . . . . . . . 2-2

2.3 Equipment Decontamination . . . . . . . . . . . . . . 2-2

2.4 Field Laboratory Methods . . . . . . . . . . . . . . . . . . . . . . 2-2

2.5 Pre-Treatment Characterization Results . . . . . . . . . . . . . . 2-4

2.5.1 Fhysical Characteristics . . . . . . . . . . . . . . . . 2-4

2.5.2 Contaminant Concentrations ............. 2-10

3. MONITORING AND MEASUREMENT ACTIVITIES $\ldots \ldots \ldots \ldots \ldots$ 3-1

3.1 Gas Analyses for Target VOCs . . . . . . . . . . . . . . . 3-1

4. RESULTS AND DISCUSSION . . . . . . . . . . . . . . . 4-1

$4.1 \mathrm{DSM} /$ Bioaugmentation Demonstration Results . . . . . . . . . . . . . 4-1

4.1.1 Bacteria/Bionutrient Background Information . . . . . . . . . 4-1

4.1.2 Bioaugmentation Operational Information . . . . . . . . 4-5

4.1.3 Fost-Treatment VOC Results from Bioaugmentation Cell . . . 4-8

4.1.4 Biodegradation vs Vapor Stripping . . . . . . . . . . . . . . . . . 4-10

4.1.5 Microbial Monitoring Results . . . . . . . . . . . . . . 4-10

4.1.6 Evaluation of Cost for DSM Using Bioaugmentation . . . . . 4-11

$4.2 \mathrm{DSM} / \mathrm{KMnO}_{4}$ Demonstration Results . . . . . . . . . . . . . 4-12

4.2.1 $\mathrm{KMnO}_{4}$ Background Information . . . . . . . . . . 4-12

4.2.2 $\mathrm{KMnO}_{4}$ Operational Information . . . . . . . . . . . . . 4-12

4.2.3 Post-Treatment VOC Results from $\mathrm{KMnO}_{4}$ Cells . . . . . . 4 4-20

4.2 .4 Oxidation vs Vapor Stripping . . . . . . . . . . . . 4-23 
4.2.5 Other Post-Treatment Sample Results from $\mathrm{KMnO}_{4}$ Cells . . . 4-24

4.2.6 Soil $\mathrm{KMnO}_{4}$ and $\mathrm{Mn}$ Concentrations . . . . . . . . . . . . . . . 4-24

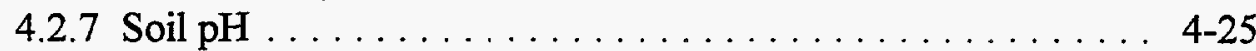

4.2.8 Soil Moisture Content . . . . . . . . . . . . . . . . . . . 4-25

4.2.9 Soil Carbon and Organic Carbon Content . . . . . . . . . . 4-28

4.2.10 Soil Microbial Analyses . . . . . . . . . . . . . . . . 4-33

4.2.11 Evaluation of Cost for DSM Using $\mathrm{KMnO}_{4} \ldots \ldots \ldots$. . . . . . .

4.3 DSM/MRVS and Powdered Calcium Oxide Injection Demonstration

Results ........................ 4-36

4.3.1 Background Information . . . . . . . . . . . . . 4-36

4.3.2 DSM/MRVS Operational Information . . . . . . . . . . 4-37

4.3.3 Post-Treatment VOC Results from MRVS Cell . . . . . . . . . 4-41

4.3.4 Evaluation of Cost for DSM Using MRVS . . . . . . . . . . . 4-43

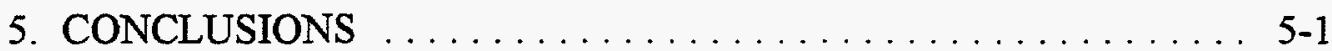

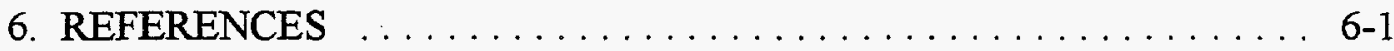

APPENDIX A Pre-Treatment Lithologic Borings

APPENDIX B Kansas City Plant Deep Soil Mixing Demonstration Project Pretreatment cis-1,2-DCE and TCE Content in Soil, $\mu \mathrm{g} / \mathrm{kg}$ and Groundwater, $\mu \mathrm{g} / \mathrm{L}$

APPENDIX C Data Acquisition Sy/stem FW vs Auger Depth Plots

APPENDIX D Treatability Studies Examining the Biodegradation of Trichloroethylene: In Support of a Field Demonstration in Kansas City, MO

APPENDIX E Kansas City Plant Deep Soil Mixing Demonstration Project Posttreatment cis-1,2-DCE and TCE Content in Soil, $\mu \mathrm{g} / \mathrm{kg}$ and Groundwater, $\mu \mathrm{g} / \mathrm{L}$

APPENDIX F Chemical Oxidation Laboratory Treatability Study Results

APPENDIX G $\mathrm{KMnO}_{4}$ Loading Rate Calculations for T5 and T4 cells 


\section{Figures}

1.1 Location of Deep Soil Mixing demonstration ............. 1-2

1.2 Conceptual view of a crane-mounted vertical rotating blade system . 1-4

1.3 Hewlett Packard 5890 Series II with auto sampler . . . . . . . . 1-5

1.4 Geologic cross section of Kansas City Plant $\ldots \ldots \ldots \ldots \ldots \ldots$ 1-7

1.5 Fence diagram of the Northeast area $\ldots \ldots \ldots \ldots \ldots \ldots \ldots \ldots$

1.6 Schematic of DSM and support equipment $\ldots \ldots \ldots \ldots \ldots \ldots$ 1-11

1.7 Photograph of DSM equipment illustrating crane, kelly bar, rotary table, shroud, and mixing tool ................. 1-12

1.8 Photograph of the 8-ft diameter mixing tool used at KCP . . . . . . 1-13

1.9 Location of wet shakedown and pre-treatment soil borings, and soil

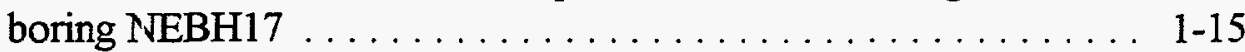

2.1 Location of pre-treatment characterization soil borings . . . . . 2 2-5

4.1 Test cell locations within the Deep Soil Mixing area ......... 4-2

4.2 T3 cell layout with soil boring locations $\ldots \ldots \ldots \ldots \ldots \ldots$ 4-3

$4.3 \quad \mathrm{~T} 4$ and $\mathrm{T} 5$ cell layouts with soil boring locations ......... 4-13

4.4 Mn concentrations of the post-treatment T5 soil borings . . . . . . 4-26

4.5 Mn concentrations of the post-treatment T4 soil borings . . . . . 4-26

4.6 Soil $\mathrm{pH}$ values of the post-treatment T5 soil borings . . . . . . . 4-27

$4.7 \quad$ Soil $\mathrm{pH}$ values of the post-treatment $\mathrm{T} 4$ soil borings . . . . . . . 4 4-27

4.8 Moisture contents of the post-treatment T5 soil borings . . . . . . 4 4-29

4.9 Moisture contents of the post-treatment T4 soil borings . . . . . . 4-29

4.10 Total carbon results for the post-treatment $T 5$ soil borings . . . . . 4-30

4.11 Total carbon results for the post-treatment T4 soil borings ..... . 4-30

4.12 Total organic carbon results for the post-treatment T5 soil borings . 4-31

4.13 Total organic carbon results for the post-treatment $T 4$ soil borings . 4-31

4.14 TOC/TC ratios for selected post-treatment T5 and T4 soil borings . 4-32

4.15 Aerobic bacteria results for the post-treatment T5 soil borings . . . 4-35

4.16 Aerobic bacteria results for the post-treatment T4 soil borings . . . 4-35

$4.17 \quad \mathrm{~T} 7 \mathrm{cell}$ layout with soil boring locations $\ldots \ldots \ldots \ldots \ldots \ldots$ 4-38 


\section{Tables}

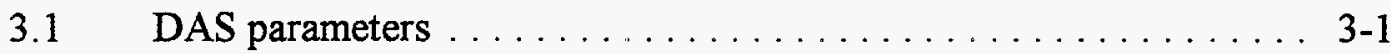

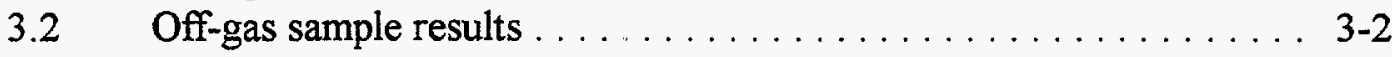

4.1 Bioaugmentation operational data . . . . . . . . . . . . . 4-6

4.2 Bioaugmentation sampling information . . . . . . . . . . . 4-7

4.3 Pre- and post-treatment average TCE concentrations in T3 Cell borings . . . . . . . . . . . . . . . . . . . . . . . 4

$4.4 \mathrm{KMnO}_{4}$ operational data .................... 4-17

4.5 DSM post-treatment analyses and procedures . . . . . . . . 4 4-19

$4.6 \quad \mathrm{KMnO}_{4}$ sampling information $\ldots \ldots \ldots \ldots \ldots \ldots \ldots \ldots \ldots .4-20$

4.7 Pre- and post-treatment average TCE concentrations in T5 Cell borings .......................... 4-21

4.8 Pre- and post-treatment average TCE concentrations in T4 Cell

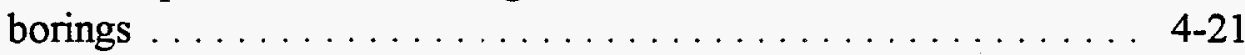

4.9 Anaerobic microbial sample results . . . . . . . . . . . . . 4-34

4.10 DSM/MRVS operational data .................. 4-40

4.11 MRVS post-treatment sampling information ........... 4-41

4.12 Pre- and post-treatment average TCE concentrations in T7 Cell borings 
Abbreviations, Acronyms, and Initialisms

\begin{tabular}{|c|c|}
\hline bgs & below ground surface \\
\hline BSM & basal salts media \\
\hline $\mathrm{cfm}$ & cubic feet per minute \\
\hline CFU & colony forming unit \\
\hline DAS & data acquisition system \\
\hline 1,2-DCA & 1,2-dichloroethane \\
\hline 1,1-DCE & 1,1-dichloroethene \\
\hline 1,2-DCE & 1,2-dichloroethene \\
\hline U.S. DOE & U.S. Department of Energy \\
\hline DSM & Deep Soil Mixing \\
\hline $\mathrm{ft}$ & feet \\
\hline FID & flame ionization detector \\
\hline $\mathrm{g}$ & gram \\
\hline gal & gallon \\
\hline $\mathrm{GC}$ & gas chromatograph \\
\hline $\mathrm{h}$ & hour(s) \\
\hline ID & inside diameter \\
\hline in. & inch \\
\hline $\mathrm{KCP}$ & Kansas City Plant \\
\hline $\mathrm{kg}$ & kilogram \\
\hline $\mathrm{KMnO}_{4}$ & potassium permanganate \\
\hline $\mathrm{L}$ & liter \\
\hline $\mathrm{lb}$ & pound \\
\hline MDNR & Missouri Department of Natural Resources \\
\hline$\mu \mathrm{g}$ & microgram \\
\hline $\mathrm{mg}$ & milligram \\
\hline $\min$ & minute \\
\hline $\mathrm{mL}$ & milliliter \\
\hline $\mathrm{mM}$ & millimolar \\
\hline $\mathrm{Mn}$ & manganese \\
\hline MRVS & mixed region vapor stripping \\
\hline NEA & Northeast area \\
\hline $\mathrm{NH}_{4}$ & sodium hydroxide \\
\hline $\mathrm{nm}$ - & nan meters \\
\hline $\mathrm{OD}$ & optical density \\
\hline ORNL & Oak Ridge National Laboratory \\
\hline PCBs & polychlorinated biphenyls \\
\hline PID & photoionization detector \\
\hline $\mathrm{ppb}$ & parts per billion \\
\hline ppm & parts per million \\
\hline psi & pounds per square inch \\
\hline
\end{tabular}


PTYG

RCRA

RFI

SOM

TC

TCE

TFHA

TFMP

TOC

TPH

VOCs

vs

wt $\%$

yd peptone-tryptone-yeast extract-glucose

Resource Conservation and Recovery Act

RCRA Facility Investigation

soil organic matter

total carbon

trichloroethene

7,7,7-trifluoro-2-hydroxy-6-oxo-2,4-heptadienoic acid trifluoromethylphenol

total organic carbon

total petroleum hydrocarbon compound

volatile organic compounds

versus

weight percent

yard 


\section{Executive Summary}

In July 1996, the U.S. Department of Energy (DOE) Kansas City Plant (KCP), AlliedSignal Federal Manufacturing \& Technologies, and Oak Ridge National Laboratory conducted field-scale tests of in situ soil mixing and treatment technologies within the Northeast Area (NEA) of the KCP. The KCP, in general, and the NEA specifically have abundant chlorinated solvent contamination located below the water table for which no viable cost effective treatment technology has been identified. While the KCP is pursuing alternate concentration limits for this and other identified contamination, this project was conceived because of the success of a soil mixing project performed to a depth of $15 \mathrm{ft}$ in low permeable clay at DOE's Portsmouth Gaseous Diffusion Plant, Piketon, Ohio. Additionally, the project was performed to obtain a benchmark for comparing cost and efficiency of other innovative technologies.

Specific performance objectives were established for the project even though it was recognized that many of the specific tasks had never before been attempted. Untried tasks included the following: drilling with air and an 8-ft diameter auger to $47 \mathrm{ft}$ in stiff clay, dry powder injection with an 8-ft diameter auger, and the introduction and mixing of liquid treatment reagents ( $\mathrm{KMnO}_{4}$ and bacteria solutions) to $47 \mathrm{ft}$ in stiff clay. This combination of untried methods and the project's overall ambitious goals resulted in some inevitable shortfalls. Nevertheless, the overall purpose of the project was satisfied by providing both a benchmark for future comparisons and a clear path forward for additional technology development.

This technology demonstration, therefore, was successful in providing answers to questions regarding the efficiency, costs, and equipment limitations of delivering three in situ treatment reagents in stiff clay soils. As a result of the demonstration the following information was obtained:

- It is possible to drill to $47 \mathrm{ft}$ in stiff clay soils and mix such soils efficiently using an $8 \mathrm{ft}$ diameter mixing tool.

- The biggest limitation for drilling and mixing to $47 \mathrm{ft}$ in KCP soils is fluid control when using water for initial drilling and liquid reagent injection during mixing. In either case, the fluids must be introduced at lower pumping rates to prevent their return to the surface and flooding of the work site.

- The most serious equipment limitation regarding dry powder injection was overcoming system and geostatic back pressure which clogged the distribution lines. With additional testing and development, this limitation could be over-come and provide a cost effective in situ treatment technology. 
- Trichloroethene (TCE) mass reductions of $70 \%$ or more were achieved by coupling deep soil mixing (DSM) with chemical oxidation using $\mathrm{KMnO}_{4}$. During the demonstration, up to $69 \% \mathrm{TCE}$ removal occurred in the saturated soil and $83 \%$ TCE removal occurred in the unsaturated soil.

- TCE mass reductions of $65 \%$ were achieved by coupling DSM with mixed region vapor stripping in unsaturated soil. Had the injection of powdered lime been achieved, treatability studies indicated that the mass reduction of TCE could be as high as $90 \%$ in saturated soil and greater in unsaturated soil.

- TCE mass reductions of $38 \%$ were achieved by coupling DSM with bioaugmentation in soil which had TCE concentrations that are toxic to the injected bacterial population. Had the bioaugmentation been performed in soil with lower TCE concentrations, the mass removal rate may have reached the $70 \%$ objective.

- The DSM/Bioaugmentation demonstration concluded that the chemical, physical and biological properties of the soil were not altered.

- Viable TCE degrading bacteria were recoverable from the upper treatment depths ( 0 to $13 \mathrm{ft}$ bgs) for at least 10 days post-treatment suggesting that TCE degradation could be continued if other limiting factors such as oxygen were augmented.

- Post-treatment microbiological studies determined that survivability of Burkholderia cepacia G4 PR $1_{30 i}$ (injected bacteria) below $13.5 \mathrm{ft}$ was minimal, probably due to the high TCE concentrations (up to $527 \mathrm{mg} / \mathrm{kg}$ ) encountered at these depths. However, laboratory testing of surviving bacteria demonstrated successful degradation of TCE confirming that the bacteria could be mixed into the subsurface and would survive the DSM process where the TCE concentrations were not toxic.

- Reagent migration was limited to areas with inherent preferential flow net-works such as fractures and the more permeable gravelly zones which are exploited and magnified by the high pressure/high volume flow of air used during initial drilling of the soil columns.

- The results of the $\mathrm{DSM} / \mathrm{KMnO}_{4}$ demonstration show that the physical and biological properties of the soil remain essentially intact. For example, microbial sampling and analysis suggest that the $\mathrm{KMnO}_{4}$ treatment could be amended with a microbial remediation treatment. Soil moisture was also affected during DSM, the average background soil moisture of $28 \%$ increased to $34 \%$ and $41 \%$ for the shallow and deep treatment cells, respectively. Increases in soil $\mathrm{pH}$ were also 
observed, due to addition of $\mathrm{KMnO}_{4}$, and these increases were not greater than the $\mathrm{pH}$ of the oxidant which was added.

- The results of the $\mathrm{DSM} / \mathrm{KMnO}_{4}$ demonstrate that the treatment reagent was well distributed in the soil and that treatment levels predicted from laboratory treatability studies can be achieved in the field.

- Although treatment costs using $\mathrm{KMnO}_{4}$ are estimated to be $\$ 128 / \mathrm{yd}^{3}$ of soil which is roughly twice the cost of the other treatments (bioaugmentation was $\$ 77 / \mathrm{yd}^{3}$ and mixed region vapor stripping was $\$ 62 \mathrm{yd}^{3}$ ), it should be noted that this oxidation treatment was also applied in both saturated and unsaturated conditions and had the highest removal efficiency. 


\section{INTRODUCTION}

\subsection{Project Description}

In July 1996, the U.S. Department of Energy (DOE) Kansas City Plant (KCP), AlliedSignal Federal Manufacturing \& Technologies, and Oak Ridge National Laboratory (ORNL), conducted field-scale tests of in situ soil mixing and treatment technologies within the Northeast Area (NEA) of the KCP at the Former Ponds site (Fig. 1.1). The drilling contractor for the project was Geo-Con (Monroeville, Pennsylvania). This demonstration, testing, and evaluation effort was conducted as part of the implementation of a deep soil mixing (DSM) innovative remedial technology demonstration project designed to test DSM in the low-permeability clay soils at the $\mathrm{KCP}$.

The clay soils and groundwater beneath this area are contaminated by volatile organic compounds (VOCs), primarily trichloroethene (TCE) and 1,2-dichloroethene (1,2DCE). The demonstration project was originally designed to evaluate TCE and 1,2DCE removal efficiency using soil mixing coupled with vapor stripping. Treatability study results, however, indicated that mixed region vapor stripping (MRVS) coupled with calcium oxide (dry lime powder) injection would improve TCE and 1,2-DCE removal efficiency in saturated soils.

This project was primarily funded by the KCP's Environmental Restoration Program (EM-40) as a result of program cost savings from process improvements. However, the existence of the project stimulated the testing of two EM-50 sponsored projects: chemical oxidation with $\mathrm{KMnO}_{4}$ and bacteria/bionutrient addition (bioaugmentation). Thus, the scope of the KCP DSM demonstration evolved to implement DSM with the following in situ treatment methodologies for contaminant source reduction in soil and groundwater:

- DSM/MRVS coupled with calcium oxide injection

- $\quad$ DSM/bioaugmentation

- $\mathrm{DSM} /$ chemical oxidation using potassium permanganate $\left(\mathrm{KMnO}_{4}\right)$

Laboratory treatability studies were started in 1995 following collection of undisturbed soil cores from the KCP. These studies were conducted at ORNL, and the results provided information on optimum reagent concentrations and mixing ratios for the three in situ treatment agents to be implemented in the field demonstration.

The field demonstration, testing, and evaluation activities involved a crane-mounted vertical rotating blade system designed to mix the subsurface using 8 to 10 -ft-dia- 


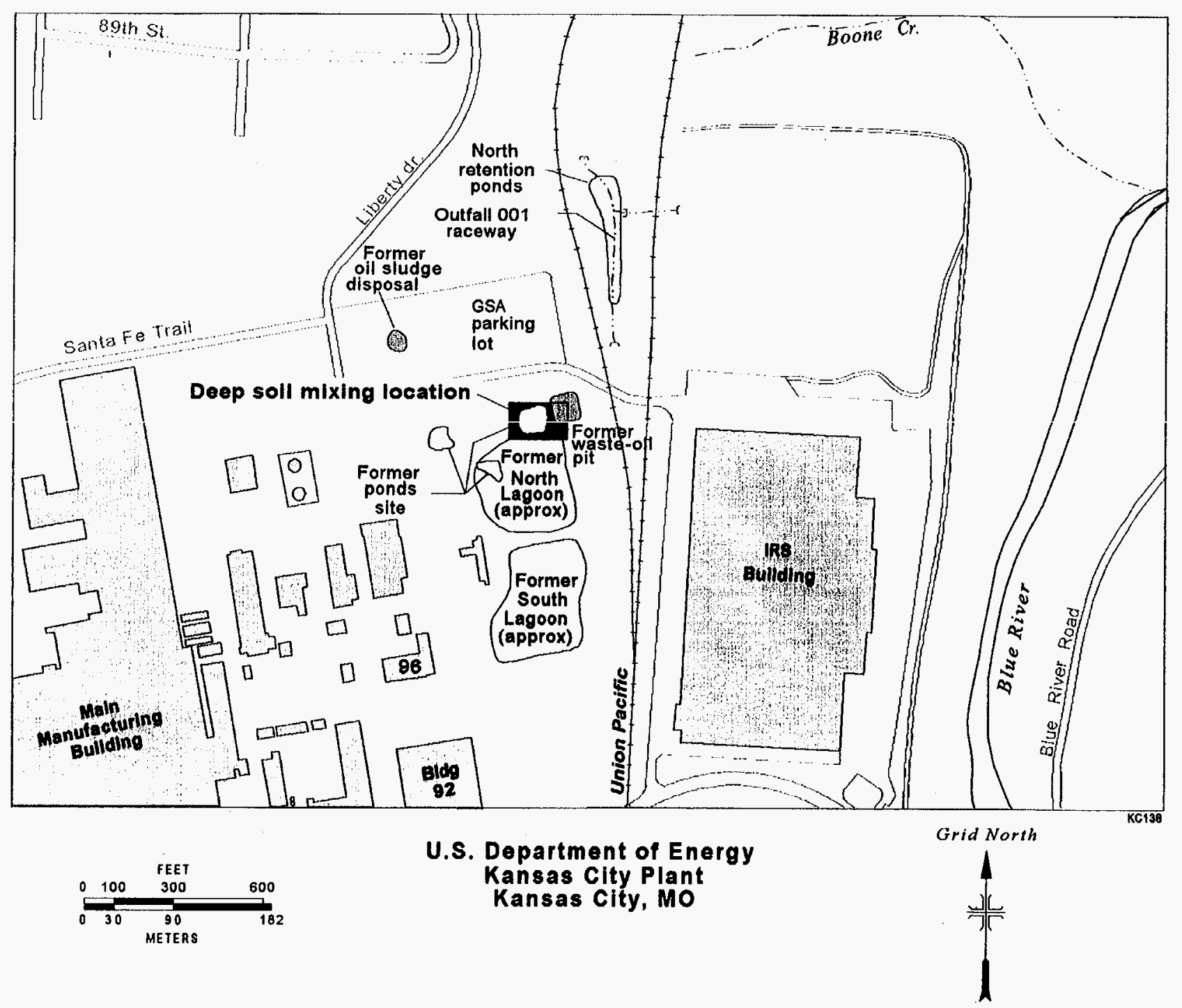

Fig. 1.1. Location of Deep Soll Mixing demonstration. 
meter blades (Fig. 1.2). During the in situ mixing process, treatment agents were injected through a vertical, hollow shaft and into the soil through orifices at the rear of the horizontal soil mixing blades.

The DSM test site, approximately $60 \mathrm{ft}$ wide by $140 \mathrm{ft}$ long, was located just north of the former North Lagoon. Here, 15 soil columns (each $8 \mathrm{ft}$ in diameter) grouped three to a treatment cell, were treated in situ to depths of approximately 25 and $47 \mathrm{ft}$. Two cells, a shallow $(25 \mathrm{ft})$ and a deep $(47 \mathrm{ft})$, were used for in situ mixing with $\mathrm{KMnO}_{4}$. One cell was used for in situ mixing with bioaugmentation to a depth of 25 $\mathrm{ft}$. The remaining two cells, a shallow ( $25 \mathrm{ft}$ ) and a deep (47 ft) were intended for the testing of DSM/MRVS coupled with dry powdered calcium oxide injection. However, limitations in the design and application of the dry powder injection system prevented successful testing of this approach. Therefore, the shallow cell was used for DSM/MRVS demonstration to $25 \mathrm{ft}$. A shakedown column was drilled to $33 \mathrm{ft}$ using a $10 \mathrm{ft}$ diameter mixing tool and served as a process shakedown to test the mixing equipment.

Monitoring and measurement activities focused on evaluation of the VOC treatment effectiveness of each process and included pre- and post-treatment soil samples, water samples, and off-gas monitoring. Pre treatment soil and water samples were analyzed in the field for target VOCs [TCE, cis- \& trans-1,2-DCE, 1,1-dichloroethene (1,1DCE), and 1,2-dichloroethane (1,2-DCA)] utilizing a Hewlett Packard 5890 Series II gas chromatograph (GC) equipped with an auto-sampler (Fig. 1.3). The posttreatment soil, water, and gas samples were analyzed with the same GC but the target compounds had been limited to TCE and cis-1,2-DCE because the pre-treatment sample results did not contain detectable levels of the other previously-targeted compounds.

It was anticipated that the stiff clay soils would challenge the successful applications of all the techniques attempted. Nevertheless, such operations under such challenging conditions had not been attempted previously and laboratory results indicated that some measure of success was likely. Consequently, the results of the laboratory experiments, and field testing should be applicable to many DOE and private sites. Specifically, the DSM demonstration was performed to answer the following questions relative to the stiff clay soils at the KCP:

- Is it possible to drill to a 47-ft depth in such soil and mix such soils efficiently?

- What are the equipment limitations for drilling and mixing to 47-ft depths in the KCP soils?

- What are the equipment limitations for delivery of dry powdered calcium oxide to the subsurface? 


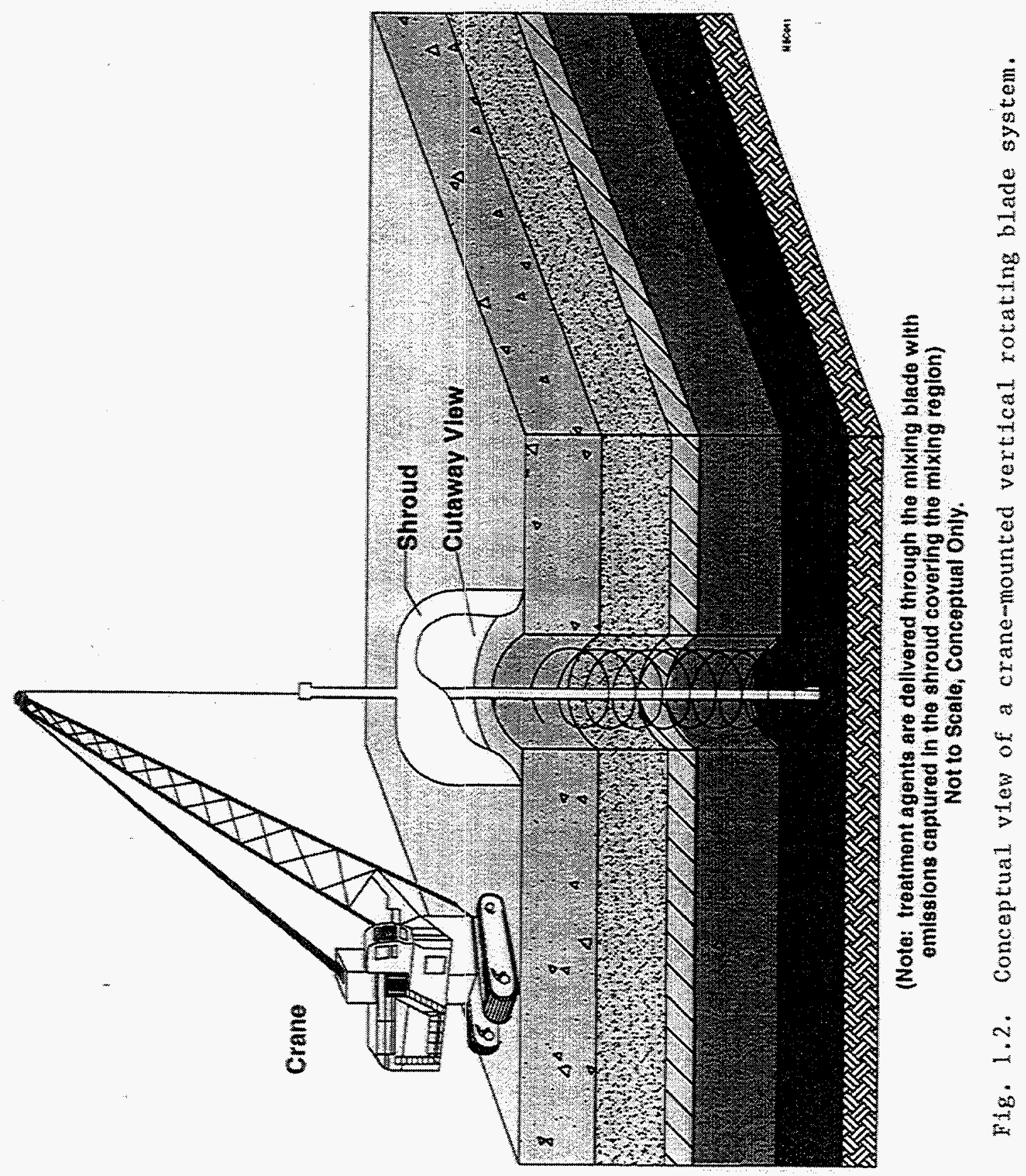




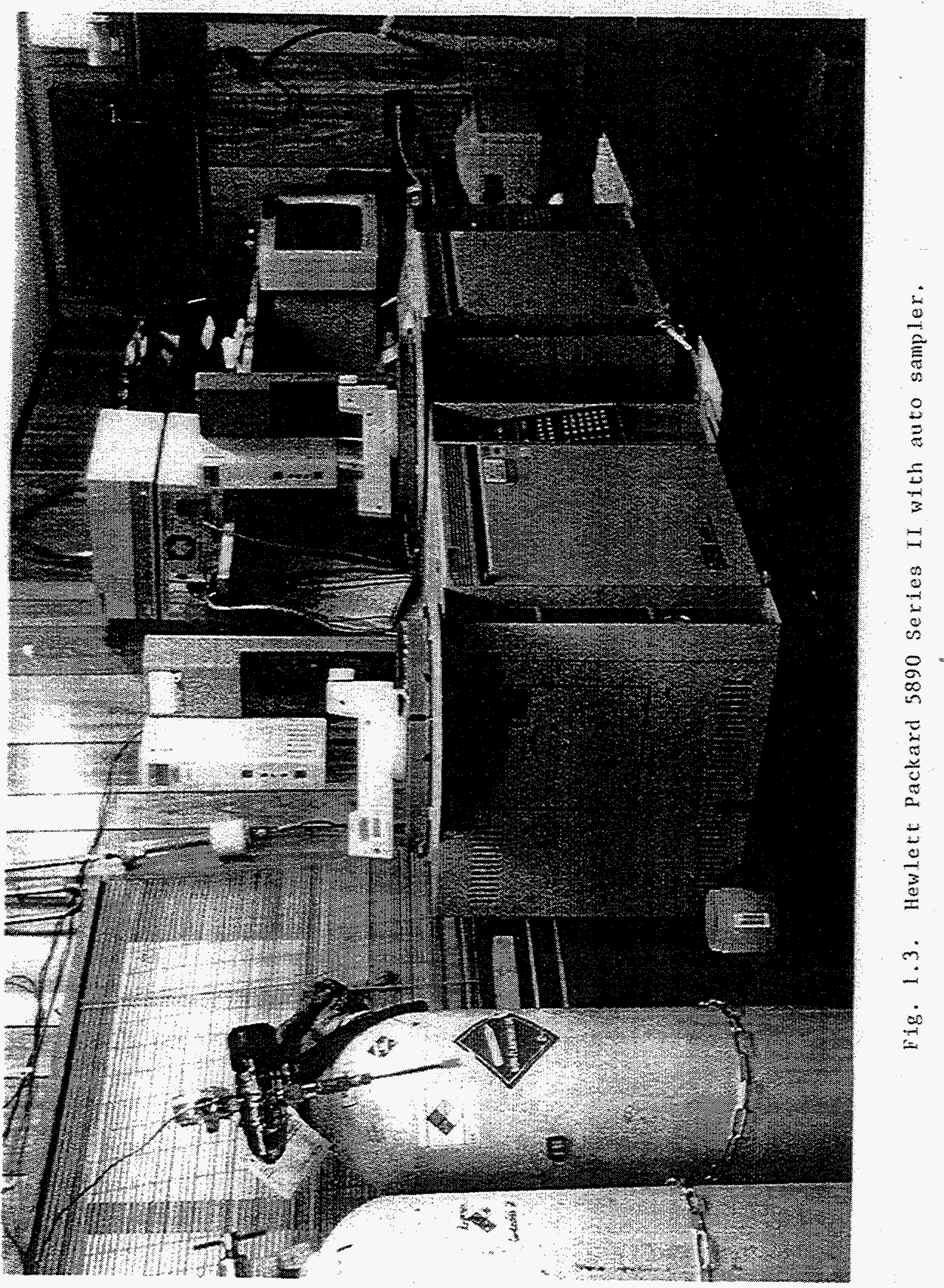


- Is it possible to degrade TCE and cis-1,2-DCE in situ to achieve a mass reduction of $70 \%$ or more in saturated and unsaturated soils by coupling DSM with bioaugmentation, chemical oxidation $\left(\mathrm{KMnO}_{4}\right)$, or $\mathrm{MRVS} /$ calcium oxide injection?

- Can treatment levels achieved in the field be predicted from results obtained in the laboratory treatability studies (specifically $\mathrm{KMnO}_{4}$ )? How well are the treatment reagents distributed in the soil?

- What effect do the treatment reagents have on the chemical, physical, and biological properties of the soil?

- Do the treatment reagents migrate beyond the boundary of the soil column(s) being treated?

- Are contaminants forced out of the treatment zone as a result of the addition of the treatment reagents?

\subsection{Site Background Information}

\subsubsection{Stratigraphy}

In the NEA, an alluvial aquifer approximately $40 \mathrm{ft}$ thick comprised of continuous and discontinuous zones of silty clay, sand, and gravel overlies Pennsylvanian age bedrock (Fig. 1.4). Within the DSM demonstration site, which is located at the western edge of the NEA (Fig. 1.5), approximately $48 \mathrm{ft}$ of alluvium overlies interbedded sand and shale of the Pleasonton Group. The alluvium is comprised of approximately $40 \mathrm{ft}$ of predominantly dark-gray, silty clay which overlies an erratic greenish-gray, silty clay up to $5 \mathrm{ft}$ thick. The lowermost member of the alluvium consists of up to $5 \mathrm{ft}$ of basal gravel. It should be noted that the extent of the greenish gray silty clay denoted in the fence diagram (Fig. 1.5) is based on color variation alone. The extent and consistency of the greenish gray silty clay unit has been found to vary widely across the NEA. It's characteristics are summarized in the NEA Resource Conservation and Recovery Act (RCRA) Facility Investigation (RFI) (U.S. DOE 1994). The basal gravel zone consists of angular limestone and sandstone gravel in a sand-silt-clay matrix, is continuous throughout the site and ranges in thickness from a few inches to $5 \mathrm{ft}$.

The interbedded sand and shale bedrock underlying the DSM demonstration site is representative of the transitional sequence demarking the lower part of the Knobtown Sandstone and the underlying shale of the Pleasanton Group (Fig. 1.4). Generally, the Knobtown Sandstone is a well-sorted, fine- to very fine-grained, lithic arkose, having a thickness of approximately $10 \mathrm{ft}$ and is comprised of monocrystalline quartz, sedimentary rock fragments, authigenic clay, potassium feldspar, plagioclase, chlorite from altered biotite, muscovite, and carbonaceous material. Results of thin-section 


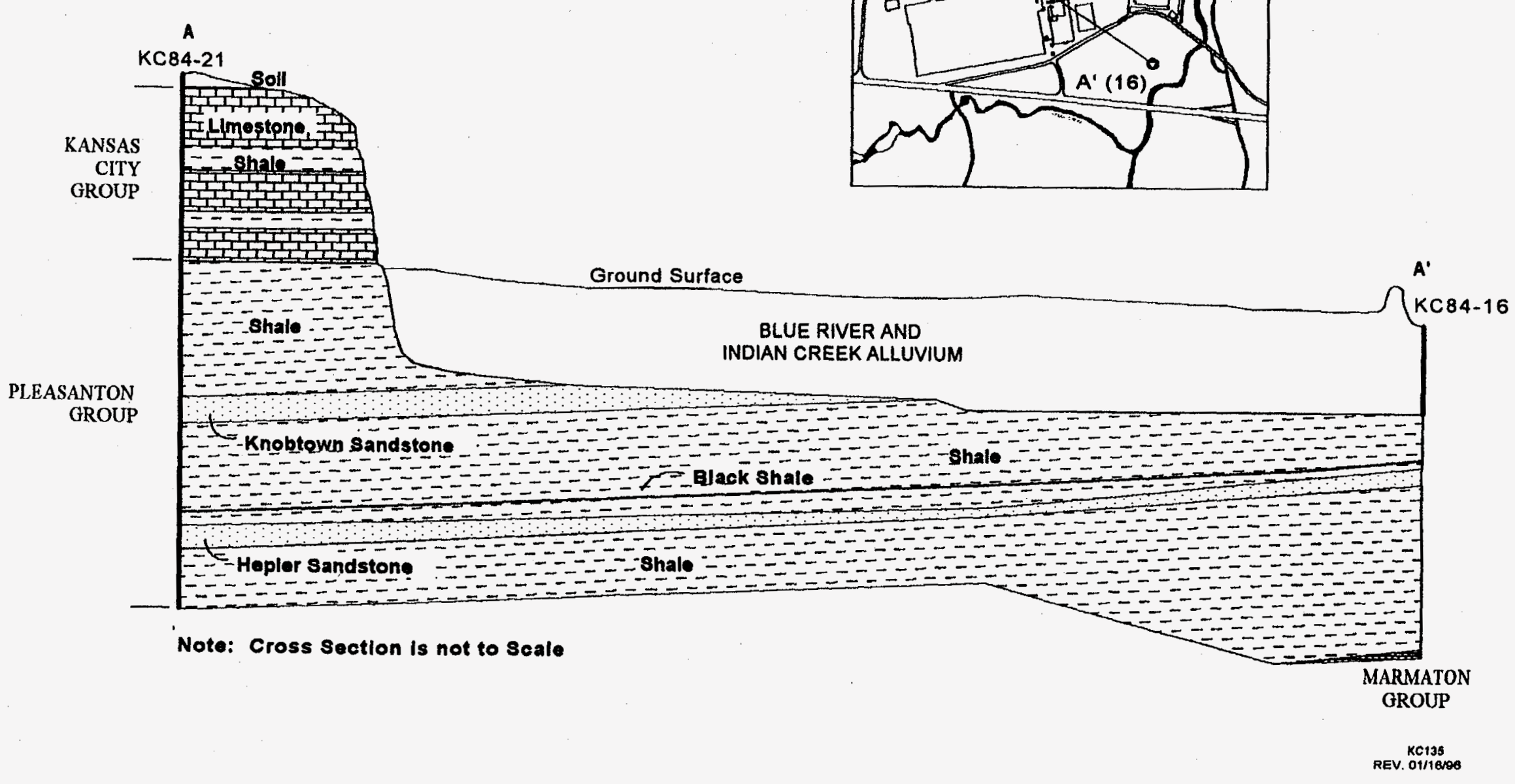

Fig. 1.4. Geologic cross section of Kansas City Plant. 


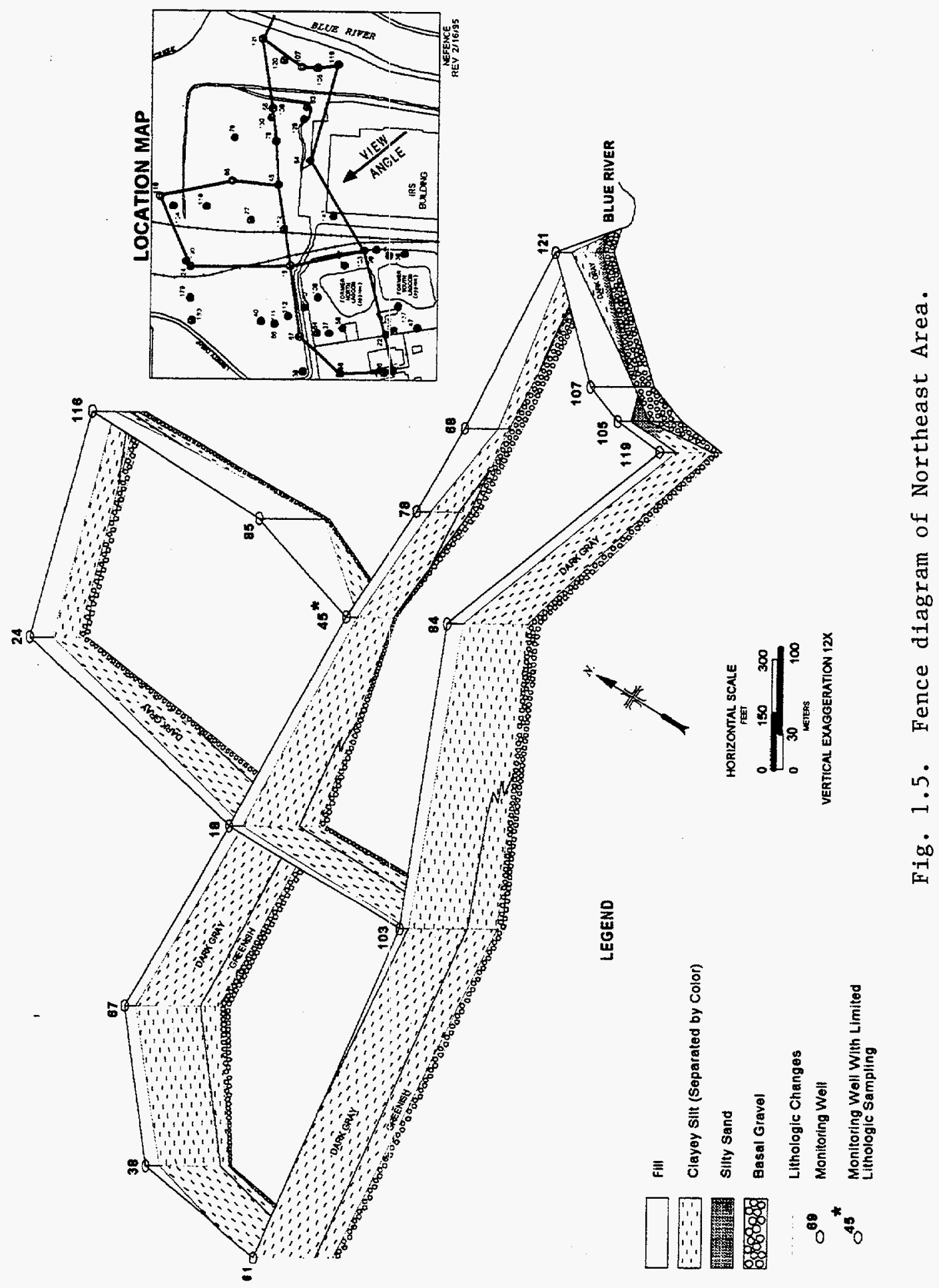


analyses indicate approximately $12 \%$ intergranular pore space (Korte et al. 1985).

\subsubsection{Description of Contamination}

The groundwater from the alluvial aquifer in the NEA has been sampled and analyzed for total metals, VOCs, semivolatile organic compounds, total petroleum hydrocarbon compounds (TPH), and polychlorinated biphenyls (PCBs) as outlined in the Northeast Area Groundwater Assessment Plan (U.S. DOE 1990). High concentrations of TCE, 1,2-DCE (over 15,000 $\mu \mathrm{g} / \mathrm{L}$ ), and chloroethene (over $1500 \mu \mathrm{g} / \mathrm{L}$ ) were detected in groundwater samples. Most of the high concentrations of VOCs were found in the vicinity (within $300 \mathrm{ft}$ ) northwest of the former North Lagoon.

Results of previous soil investigations in the NEA are presented in the NEA RFI (U.S. DOE 1994) summarized below. Elevated levels of TPH ranging up to $6,961 \mathrm{mg} / \mathrm{kg}$ have been documented. The highest PCB concentration reported was $9.8 \mathrm{mg} / \mathrm{kg}$. The highest concentrations of chlorinated solvents reported in the soil were found below the water table; TCE, $81 \mathrm{mg} / \mathrm{kg}$ and 1,2-DCE, $15 \mathrm{mg} / \mathrm{kg}$. Chloroethene and chlorobenzene were reported less frequently, but at concentrations up to 0.770 $\mathrm{mg} / \mathrm{kg}$.

\subsection{Process Operations}

\subsubsection{Site Preparation}

As stated above, the DSM demonstration site is located just north of the north lagoon. The area was originally grassy with a make-shift gravel road encircling the area formerly inscribed by the now closed and capped north and south lagoons. The demonstration site was laid out with a gravel base and contoured to promote drainage away from the test cells within the demonstration site. Additionally, the demonstration area was encircled with an earthen/gravel dike and adjacent storm drains were protected by a series of earthen dikes covered with an impermeable fabric material. Electrical power requirements for the demonstration were arranged and provided by $\mathrm{KCP}$ personnel.

\subsubsection{Permitting Requirements}

A Missouri Department of Natural Resources (MDNR) Underground Injection Control permit was required for the DSM project at the KCP. Though the demonstration did not utilize "wells" to inject wastes into the subsurface as is typical with permits of this type, state statute required the permit as injection of materials into "waters of the state" (in this case groundwater) occurred. The type and amount of reagents to be injected as a part of the demonstration were required. In addition, 
reagents to be injected as a part of the demonstration were required. In addition, analysis of groundwater from an existing groundwater monitoring well was required upon completion of the demonstration. This information was collected and forwarded to MDNR as required by the permit.

\subsubsection{DSM Equipment Description}

A schematic of the DSM equipment is presented in Fig. 1.6. In situ mixing was performed using an 8-ft diameter mixing tool connected to a 12.75-in. square, hollow, kelly bar. This assembly was powered by a crane-mounted rotary drill table mounted from the crane boom. A photograph of the crane and mixing assembly is provided in Fig. 1.7. The mixing tool, illustrated in Fig. 1.8, was composed of three individual auger flights, spiral-wound around the shaft with three beater bars or mixer paddles attached above the auger flights. The leading edge of each auger flight was equipped with eight teeth and the shaft had a pilot bit with three teeth. Mounted behind and parallel to the cutting edge of each auger flight was an air box fitted with threaded ports or nozzles along its length and end (Fig. 1.8). The nozzles were threaded to permit the installation of reducers to accommodate the different soil treatment media. A 13-ft diameter cylindrical steel hood was mounted over the mixing location to capture and contain off-gas vapors generated during drilling and mixing. A flexible rotating seal in the center of the hood allowed the kelly bar to pass through the hood and minimized venting of off-gas to the atmosphere. Mounted on top of the hood, two 6-in. vacuum lines connected to three vacuum extraction units which routed the off-gas through granular activated carbon before release to the atmosphere. Leaking around the base of the hood was minimized by maintaining it on the ground surface during all drilling and mixing operations. Mixing and drilling were completed using air supplied from two modified compressors. For the oxidation and bionutrient mixing operations, the air was turned off upon reaching the pre-determined depth (25 or $47 \mathrm{ft}$ ) and the respective treatment agents were then injected into the column. Initial drilling and ensuing downward mixing were completed using clockwise rotation to the mixing tool and kelly bar. Liquid reagents were delivered at a constant pumping rate (with a Moyno L12 pump) while rotating the mixing tool out from the bottom of the column to the top in a counter-clockwise direction.

\subsubsection{Shakedown/DSM Operational Limitations}

As noted in Sect. 1.1, this project was initiated with full knowledge that equipment limitations would be encountered as a result of the stiff clay soils found at the KCP. This section details some of the limitations that were identified. 

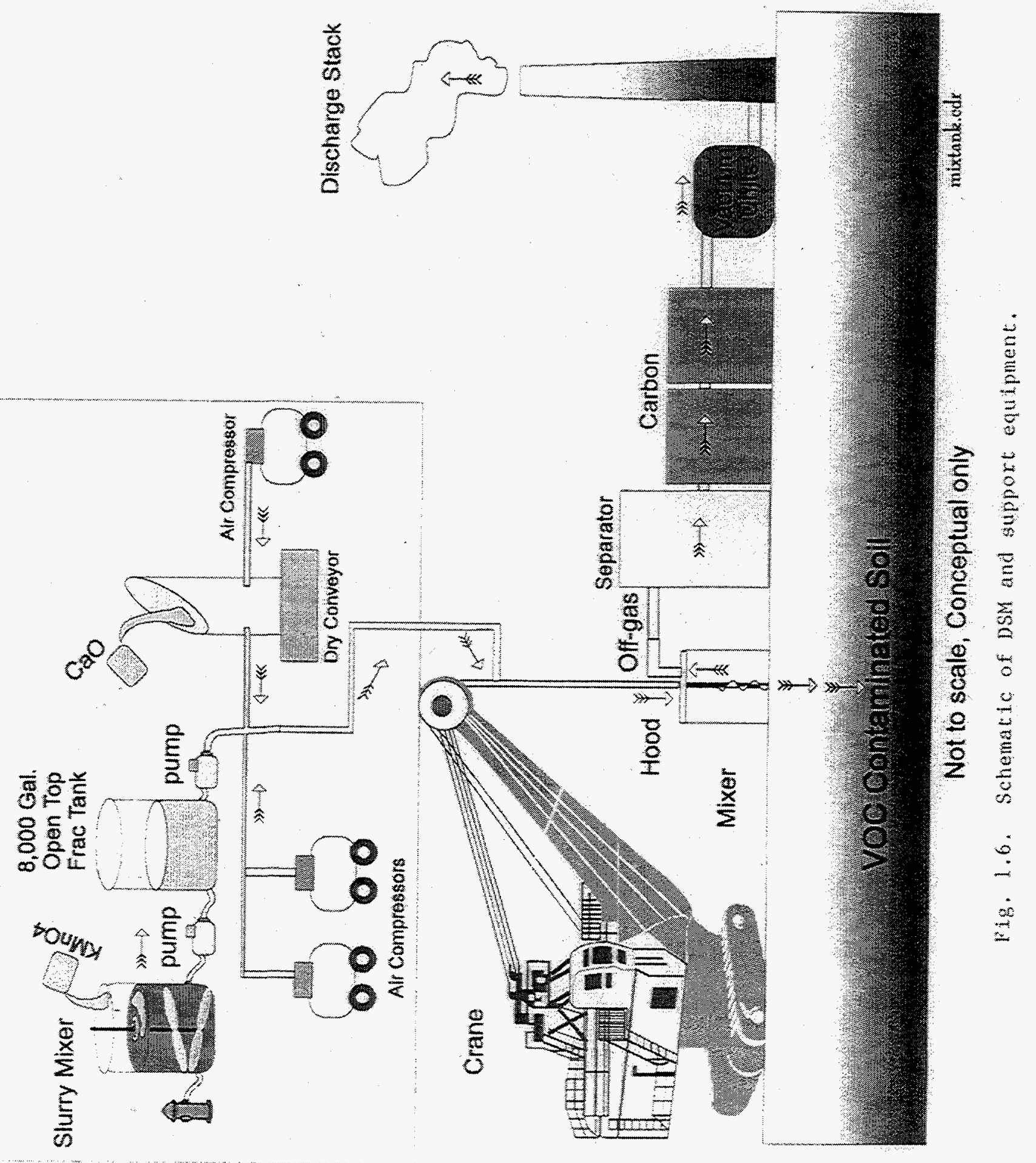


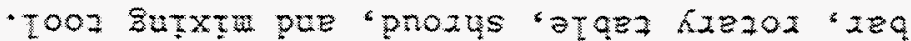

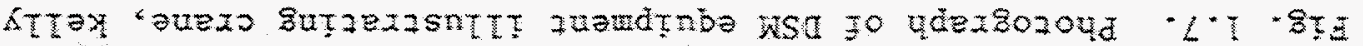

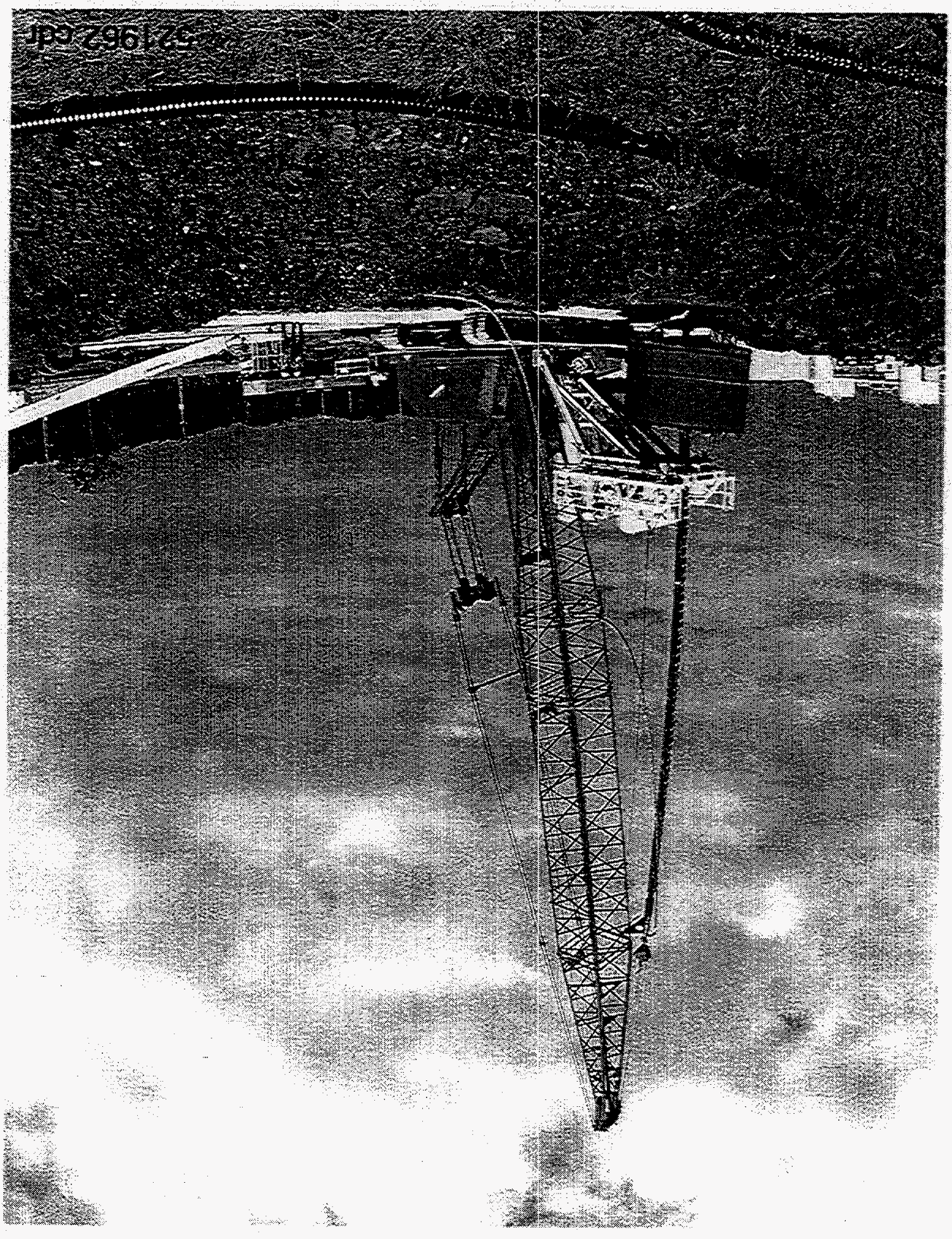




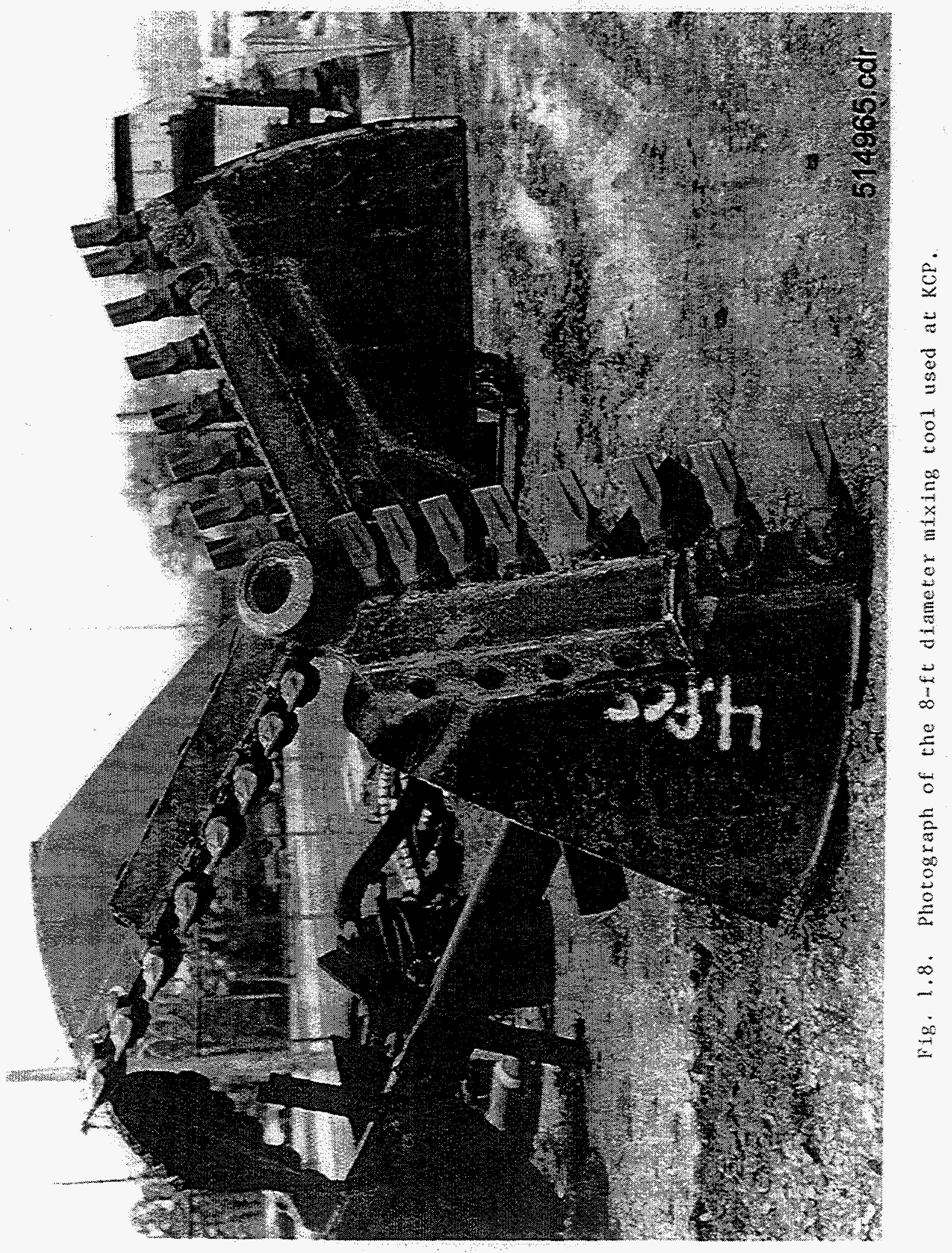


The field project began with drilling subcontractor mobilization in April 1996 with a planned start in mid-May. This was Geo-Con's (drilling subcontractor) first attempt to work with a newly manufactured 10-ft diameter mixing tool and a remanufactured and untested kelly bar. When the first column (shakedown) was attempted, the mixing tool did not penetrate more than a few feet. Moreover, the kelly bar was damaged because it wobbled and banged against the rotary table. Following a twoweek delay to complete welding repairs to the kelly bar, a second shakedown using an 8- $\mathrm{ft}$ diameter mixing tool was performed in an adjacent but unapproved location was attempted. This time the mixing tool penetrated to a depth of about $8 \mathrm{ft}$ where subsurface conditions caused one of the blades on the tool to break off. Additional damage was also sustained by the kelly bar. Following an eight week-delay needed to modify another kelly bar, the project was reinitiated on July 8,1996 . During the delay, Geo-Con surmised that the original kelly bar, which had been purchased from a third party, failed due to problems with the quality and temper (hardness) of the steel used by the manufacturer. The cause for the breakage of the 8-ft mixing tool was attributed to subsurface debris.

On July 9, prior to any shakedown, Geo-Con suggested a deviation from the original plan of performing the wet and dry shakedowns before proceeding with the actual demonstrations. The suggestion was based on their concern that time would be best served by performing the wet shakedown and the two wet injection demonstrations (bioaugmentation and chemical oxidation) first and then switching over to the dry injection (powdered lime). By doing this, it was believed that time could be saved by avoiding switching the wet and dry injection systems. Additionally, Geo-Con was eager to demonstrate that their modified equipment could succeed in drilling/mixing the KCP soils and had more confidence in the use of water versus air for the initial shakedown. This decision had two significant consequences which are addressed in the following paragraphs.

On July 10 , prior to treatment reagent testing, a wet shakedown soil column was drilled near the western edge of the demonstration area (Fig. 1.9). The original location for the shakedown (X1B1 in Fig. 1.9) had been eliminated due to difficult drilling conditions documented during pre-treatment characterization efforts (these findings are discussed in Sect. 2.5.1.) Using the pretreatment characterization boring data, it was evident that the $\mathrm{T} 1$ and $\mathrm{T} 2$ cells contained varying amounts of concrete debris in the first 10 to $12 \mathrm{ft}$ of soil. Therefore, the location of the shakedown column was centered between borings T2B4 and T2B5 in Fig. 1.9. Although other borings in the T2 cell had encountered debris, the T2B4 and T2B5 borings had encountered no obstructions. The shakedown column was drilled with water to a depth of $22 \mathrm{ft}$ where the mixing tool encountered resistance and the penetration rate stopped. Consequently, the drilling assembly was pulled to the surface and approximately 20 $\mathrm{ft}$ of 1-in. diameter steel cable was found tangled up in the teeth of the pilot bit. The 


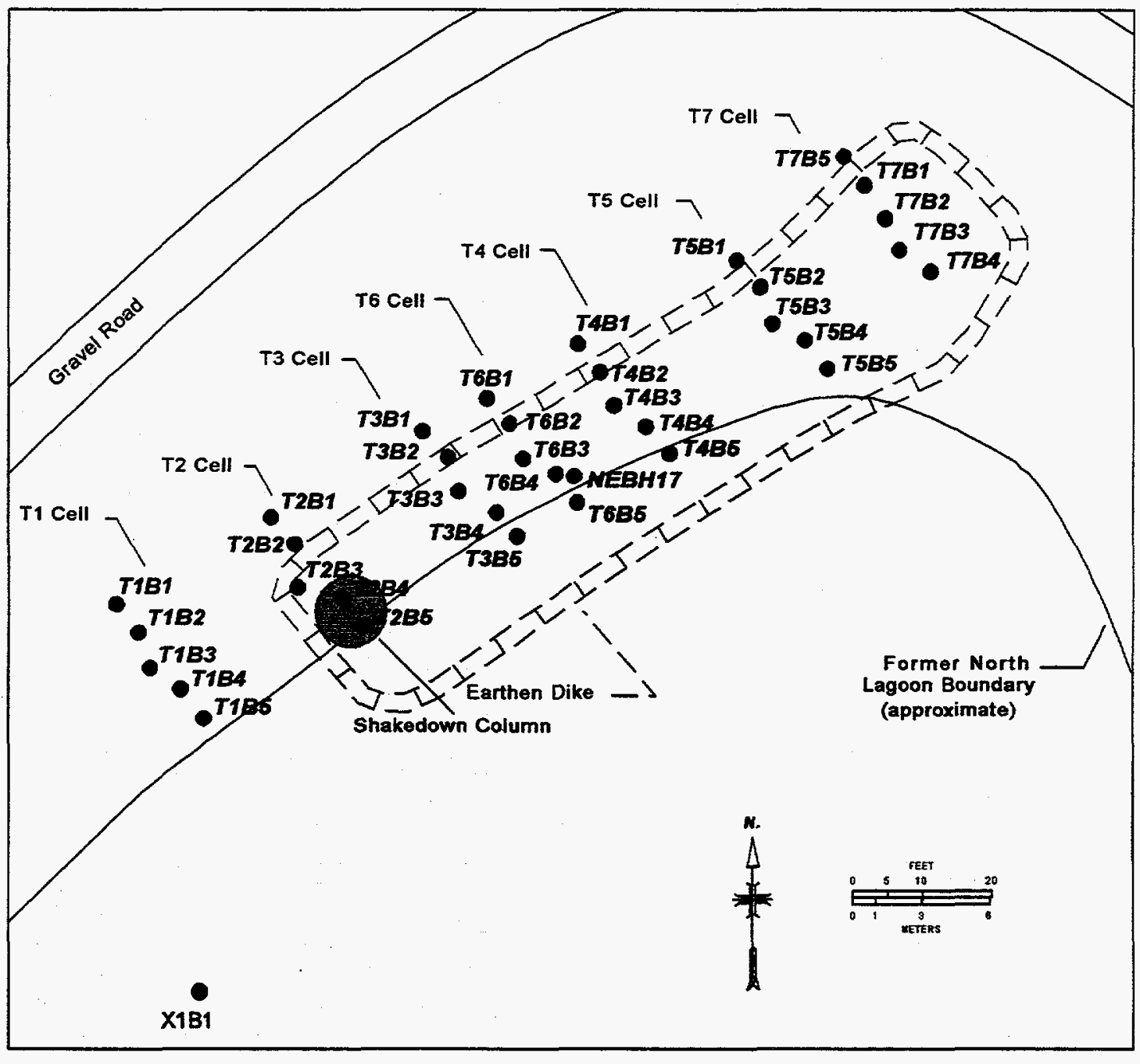

- Pre-Characterization Borehole

Fig. 1.9. Location of wet shakedown and pre-treatment soil borings, and soil boring NEBH17. 
cable was removed and drilling resumed to $33 \mathrm{ft}$. This event was significant because it confirmed that the usefulness of the $\mathrm{T} 1$ and $\mathrm{T} 2$ cells for additional shakedown or reagent demonstrations would be thwarted by debris.

Due to the large volume of water needed to successfully drill with the 10-ft diameter mixing blade and the fact that its capability of reaching 45 -ft depths was doubtful based on the observed decrease in the rate of penetration below $30 \mathrm{ft}$, a mutual decision was made to use the 8-ft diameter mixing tool for all of the subsequent reagent demonstrations.

The wet shakedown test, which was successful in proving the DSM equipment would work in the stiff clay soils, unfortunately used a large volume of water $(41,640 \mathrm{~L})$, much of which returned to the surface as a sediment slurry. This water leaked out from under the shroud and pooled across the bermed area. Most of the water/sediment slurry eventually flowed to the north east corner of the bermed area (T7 cell) resulting in 3 to $4 \mathrm{ft}$ of water/sediment slurry which was too thick to pump with the equipment provided by the subcontractor. The presence of the pooled water/sediment slurry over the $\mathrm{T} 7$ cell influenced the DSM/bioaugmentation demonstration for various reasons addressed in the next paragraph.

Because the T7 cell had an average of 20 parts per million (ppm) TCE in the soil and bioremediation is most effective at contaminant concentrations up to $10 \mathrm{ppm}$, the T7 cell had been the planned location for the DSM/bioaugmentation demonstration. Unfortunately, the bacteria culture had already been prepared and would degrade in effectiveness with time. Due to the flooded condition of the T7 cell, a decision was made to relocate the DSM/bioaugmentation demonstration to a cell (T3 cell) with significantly higher average TCE concentrations of $126 \mathrm{mg} / \mathrm{kg}$. The presence of the aforementioned obstructions in the $\mathrm{T} 1$ and $\mathrm{T} 2$ cells in conjunction with relatively low levels of contamination in these cells ruled them out as potential candidates for the DSM/bioaugmentation demonstration.

The intent of the DSM/MRVS couplecl with calcium oxide injection was not satisfied because of the inability of the equipment to deliver calcium oxide below the ground surface. Because a dry shakedown had not been performed as originally planned, this problem was not discovered until late in the demonstration program and options to correct the problem were limited by contractual and budget limitations. Although Geo-Con could convey calcium oxide to the nozzles on the mixing blades with the mixing tool above the ground surface, below ground the back pressure created was insurmountable. It should be noted that calcium oxide injection has been achieved on smaller scale using 18 to 24 -in. diameter mixing tools where compressed air forced the lime powder from an elevated container into the auger shaft and out through holes in the lower end of the auger shatt (Booms 1991). The technique used by GeoCon at KCP, however, which involved a dry conveyor to force the lime powder from 
the ground surface to the top of the kelly bar and eventually through the nozzles located on the air boxes under the mixing blades, had not been previously attempted. The net result was a condition of insurmountable backpressure after repeated attempts to deliver lime, it was determined that the scope of the demonstration would be limited to DSM using MRVS in one cell to $25 \mathrm{ft}$ (T7). Therefore, the T6 cell which had been planned to demonstrate the same treatment to a depth of $47 \mathrm{ft}$ was not used for any of the demonstrations. In retrospect, had the limitations with the dry conveyor system been identified earlier in the field program, more steps could have been taken to correct the problem.

Another significant and recurring problem was the collapse of one or both vacuum lines during mixing operations. The collapse in the line(s) resulted from too much slack in the thin-walled tubing which was not properly adjusted each time the shroud position changed. Therefore, a great deal of the data collected to measure the volume and pressure of the off-gas is of questionable value.

During the initial drilling of the bioaugmentation cell (T3) several blowouts were observed where, as a result of too much air pressure and volume, the ground surface mounded and then receded after the air escaped via a fracture. This was subsequently controlled by reducing the air volume and pressure.

Another operational problem was related to the repeated failure of the flexible seal located at the top of the shroud. The seal needed to remain intact or the off-gas vacuum system was ineffective. The stiff clayey nature of the KCP sediments, however, were instrumental in the seal failure. As the kelly bar and mixing tool were rotated out of the hole (upward), it was noted that the kelly bar was coated with sticky clay. It was surmised that the clay was repeatedly wearing against the tightfitting seal and eventually would cause its failure. To thwart the problem, the subcontractor began using a stream of high pressure water to remove some the clay from the kelly bar after it had traveled up through the seal to prevent it from causing more damage during downward movement. The seal was the subject of various repair efforts throughout the field demonstration. In particular, there were persistent problems with seal during the bioaugmentation demonstration, when the seal failed twice during the mixing of three columns. Each time the seal broke, approximately 1 to $2 \mathrm{hrs}$ were required for repair. The time loss prevented additional mixing passes. Thus, although the reagent was successfully added and mixed with soil at a controlled rate, the thoroughness of the mixing was less than anticipated.

Some of the previously noted limitations created additional data collection problems for the data acquisition system (DAS). For example, as a result of the high pressure washing of the kelly bar previously noted, the off-gas temperature and pressure sensors which were located on top of the shroud consistently short-circuited as their installation and design had not anticipated the volume or pressure of water used to 
clean the kelly bar. Similarly, the recurring problem with the collapse of the off gas tubing limited the reliability of the flow sensor data collected in the tubing run between the shroud and the vacuum units. Consequently, the mass of VOCs in the off gas could not be calculated.

In conclusion, it is not surprising that some of the previously presented DSM operational problems and limitations were encountered. After all, much of what was being tried had never been attempted before. However, much of the delay and equipment problems could have been avoided or reduced with better preparatory efforts on the part of the drilling contractor. 


\section{INVESTIGATTVE METHODS}

The following sections present the discussion of investigative methods used to assess VOC content in pre- and post-treatment soil and groundwater samples.

\subsection{Soil Sampling}

Pre-treatment characterization soil sampling was performed with a truck mounted Mobile B-61 rig equipped with 6.25 in. outer diameter, hollow stem augers. A 5-ft long continuous soil sampler was advanced with the hollow stem augers to collect soil samples. Post-treatment characterization soil sampling was accomplished using a direct push rig and Geoprobe Megabore samplers (1.75 by 48 in.) equipped with acetate liners. The depth objectives of the pre- and post-treatment soil sampling correspond with the planned treatment depths for each of test cells discussed in Sect. 1.1.

Upon extraction from the boring, the continuous sampler/acetate liner was opened and samples from the intervals designated in the work plan were collected immediately. These intervals were generally every $5 \mathrm{ft}$ beginning at $1 \mathrm{ft}$ below ground level. A soil sample was always collected at the bottom of the last sampler, representing the bottom of the boring.

Soil samples from the designated intervals were collected by breaking the soil core open and immediately pushing a small coring device (microcore) into the freshly exposed surface. The microcore collected approximately $5 \mathrm{~g}$ of soil which was immediately extruded into a tared $40 \mathrm{~mL}$ VOC vial containing $5 \mathrm{~mL}$ of hexane and 5 $\mathrm{mL}$ of deionized water. The vial was labeled and placed in a cooler with Blue Ice. The hole in the soil core created by the microcore was immediately monitored with the photoionization detector (PID). These measurements provided a qualitative measure of the contamination present in the samples.

After the interval samples were collected, the soil core was split lengthwise with a knife. The tip of a PID was then drawn along the split soil to monitor for elevated VOC levels in the core. If elevated levels were discovered, the field team decided whether to collect a biased sample at that location. This decision was based on the relative magnitude of the elevated PID reading compared to other PID measurements from previous soil samples in the boring and the appearance of the core. If a sample was collected, the previously described microcore sampling method was used.

In addition to the soil samples for VOC analysis, several soil samples were collected for various laboratory experiments (treatability studies for MRVS and chemical oxidation) related to the soil mixing process and treatment agents. These were 
collected in acetate or brass sleeves or liners, tightly sealed in the collection sleeves, preserved with Blue Ice, and shipped to the laboratory for further use.

\subsection{Groundwater Sampling}

Pre-treatment groundwater samples were collected by lowering a Teflon bailer into the hollow stem augers. Post-treatment groundwater samples were collected with a stainless steel bailer from temporary $3 / 4$-in. inside diameter (ID) piezometers installed in selected post-treatment borings. The bailer was recovered and the groundwater was decanted into an empty $40 \mathrm{~mL}$ VOC vial until the vial was full. Upon arrival at the analytical laboratory, the analyst opened the vial and withdrew $5 \mathrm{~mL}$ of the water and injected it into $5 \mathrm{~mL}$ of hexane.

\subsection{Equipment Decontamination}

All sampling equipment was decontaminated between each use. Drilling equipment (i.e., augers, bits, "A" rods, and Geoprobe tools) was decontaminated between each boring. Decontamination was accomplished using a high-pressure hot water washer. Syringes used for groundwater sample transfer and microcore tools were purchased pre-sterilized, used once, and discarcled.

Duplicate soil and groundwater sarnples were collected at a frequency of $10 \%$. Equipment rinse samples were collected daily by pouring deionized water through decontaminated sampling equipment into a $40 \mathrm{~mL}$ vial. Field blanks were collected from the deionized water used for equipment rinse samples and from every tank of potable water used by the high-pressure, hot water washer.

All field quality assurance samples were analyzed in the field laboratory using the same techniques and analytical equipment that were used for environmental samples.

\subsection{Field Laboratory Methods}

Before collection of pre- and post-treatment soil samples, each $40 \mathrm{~mL}$ vial was prepared as follows: a sample label was attached, $5 \mathrm{~mL}$ of hexane and $5 \mathrm{~mL}$ of deionized water were placed in each vial, the vial was weighed, and this tare weight was written on the vial's label. The vials were placed in a clean cooler with Blue Ice and taken to the field for sample collection. 
Upon return to the field laboratory, each vial was weighed in order to obtain an accurate weight of the soil in the vial.

Initially, the sample extractant was diluted based on the PID measurement of the soil sample in the field. However, the PID measurements proved to be of limited value. Additional dilution of samples was often required because the field $\mathrm{GC}$ was calibrated to be linear within a range of 5.0 parts per billion (ppb) to $1000 \mathrm{ppb}$ and many samples were outside of that range.

Dilutions were accomplished by extracting $0.5 \mathrm{~mL}$ of hexane from the sample vial and placing this in $4.5 \mathrm{~mL}$ of hexane to create a 1:10 dilution. Dilutions of 1:100 were accomplished by placing $0.05 \mathrm{~mL}$ of extractant in $4.95 \mathrm{~mL}$ of hexane. Further dilutions, when required, were accomplished using the same methods and starting with the 1:100 dilution created previously. All bottles were labeled with the sample number and dilution. All transfers and dilutions used new bottles and pipette tips. The original sample and all dilutions were stored until the GC runs were complete and the results were within the linear range of the GC.

One (1) $\mathrm{mL}$ of hexane from the required dilution was placed in a $2 \mathrm{~mL}$ septa top vial and loaded into the autosampler for GC analysis. The first sample loaded in the autosampler was a blank, consisting of $1 \mathrm{~mL}$ of hexane in a sample vial.

All samples were analyzed on a Hewlett-Packard 5890 Series II GC equipped with a HP-624 capillary column and an electron capture detector. For the pre-treatment characterization, the GC was calibrated for TCE, cis- \& trans-1,2-DCE, 1,1-DCE and 1,2-DCA. Because the only detectable compounds in the pre-treatment samples were TCE and cis-1,2-DCE, the post-treatment characterization limited the GC calibration to the latter two compounds. A calibration curve for TCE was generated from standards at concentrations of $50,100,250,500,750$, and $1000 \mathrm{ppb}$. The calibration curve for the other compounds was generated from standards at concentrations of $200,500,1000$, and $2000 \mathrm{ppb}$. Standards were prepared from custom mix standards diluted to create the range of concentrations. Following initial calibration, standards were run at least every two days to check retention times and concentration determination.

One (1) $\mu \mathrm{L}$ of extractant liquid was injected directly on the column using a HP7673A autosampler, the autosampler was controlled with a HP3396 Series II integrator. Chromatograms were collected, stored, and reported using Chrom-Perfect, Version 5.05/6.07. Dilution information was entered into ChromPerfect and the concentration of contaminant in each sample were calculated automatically. The analyst calculated the concentration of contaminant per gram of sample and entered that value in the logbook. Following the GC runs, sample reports were studied to determine if any samples were outside the calibration range or if any of the blanks contained 
contamination. No blanks were contaminated. Several samples were out of range; these samples were further diluted, as needed, and reanalyzed usually within a holding time of less than 2 to 3 days.

\subsection{Pre-Treatment Characterization Results}

\subsubsection{Physical Characteristics}

Pre-treatment characterization began at location X1B1 to a depth of $51 \mathrm{ft}$ (Fig. 2.1). The $\mathrm{X}$ is the test cell designator and $\mathrm{B} 1$ identifies the location as borehole 1. X1B1 is located outside of the actual treatment area. X1 was planned as "shakedown" area where the DSM process would be tested prior to treating contaminated soil. Following X1B1, all five borings in the T1 cell were drilled to $25 \mathrm{ft}$. The low level of contaminants in $\mathrm{T} 1$ and some riprap encountered at depths of 6 to $10 \mathrm{ft}$ caused the field team to change the strategy slightly. Instead of drilling all five borings in one test cell, one boring was drilled in each test cell to determine if unexpected problems would be encountered. Borings T2B3, T3B3, T4B3, and T5B3 followed in that order. No significant problems were encountered in these borings. Therefore, all borings were completed in T2 to bedrock, T3 to $25 \mathrm{ft}, \mathrm{T} 4$ to bedrock, and T5 to $25 \mathrm{ft}$.

In T2, borings T2B1 and T2B2 encountered large gravels and obstructions at depths from 3 to $10 \mathrm{ft}$. In addition, the contarninant concentrations in this test cell were very low compared to concentrations in other test cells. Based on the problems drilling in $\mathrm{T} 1$ and $\mathrm{T} 2$ and the low level of contaminants present, other test cells were added (T6 and $\mathrm{T} 7$ in Fig. 2.1). T6 was located between T3 and T4, T7 was located east of T5. These locations were chosen based on logistics of reaching the cells with the mixer, the likelihood of encountering contamination, and the apparent lack of drilling obstacles in the eastern portion of the test area.

A detailed lithologic log was prepared for one boring in each of the test cells, except test cell 6 . A lithologic log from test cell 6 was not prepared because T6B3 was drilled approximately 18 in. from NEA Borehole 17 (NEBH17), a borehole drilled as part of a RCRA facility investigation previously performed in the NEA. Detailed lithologic logs from the test cells and NEBH17 are provided in Appendix A. A brief lithologic description of each test cell follows.

Shakedown X1B1: The soil consisted of predominantly silty clay fill to a depth of approximately $15 \mathrm{ft}$. An obstruction, probably a cobble or other riprap, was encountered at $10 \mathrm{ft}$. The continuous sampler was removed in order to drill through the obstruction (10 to $12 \mathrm{ft}$ ). Sample recovery from 12 to $15 \mathrm{ft}$ was low as debris 


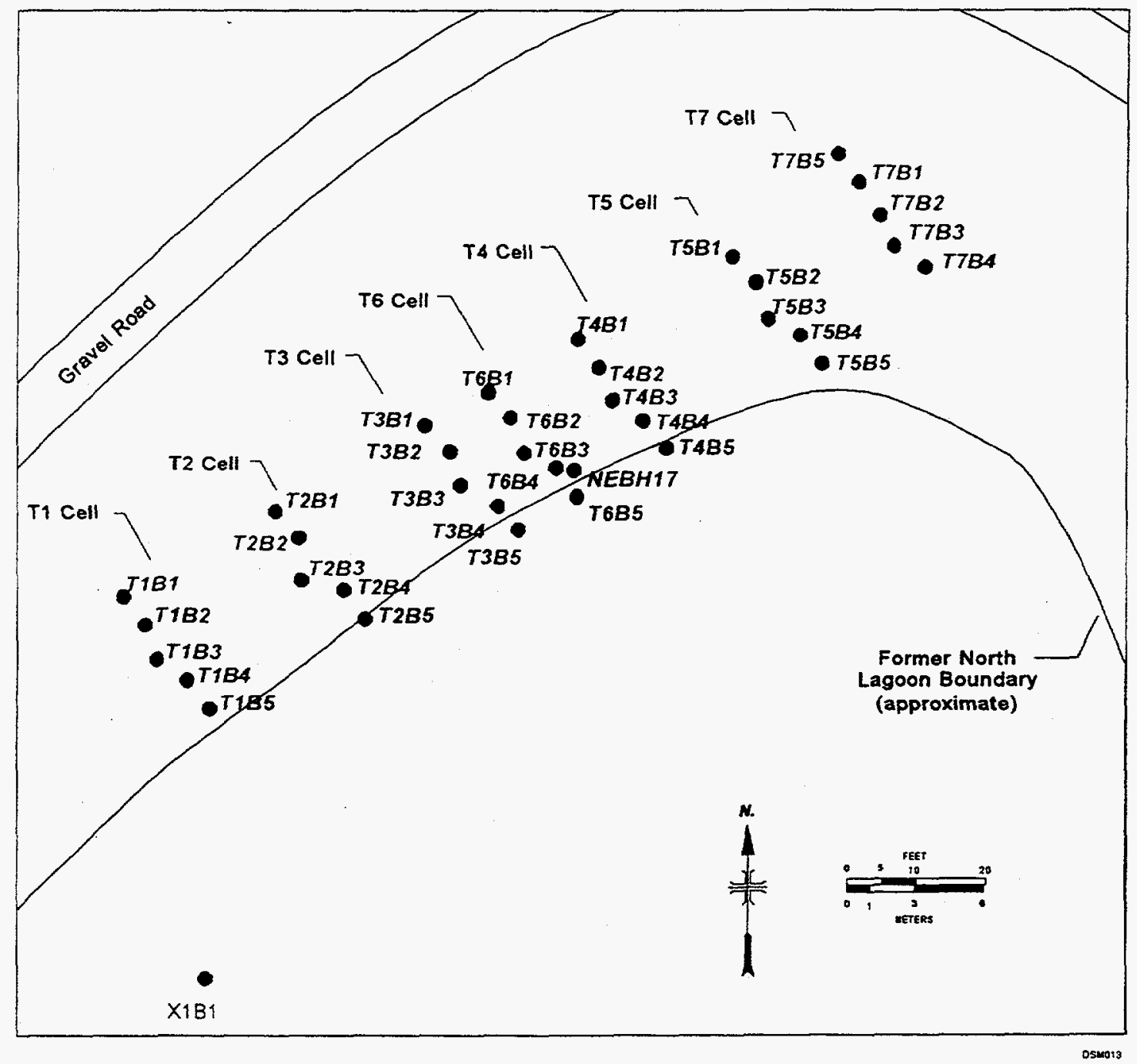

- Pre-Characterization Borehole

Fig. 2.1. Location of pre-treatment characterization soil borings. 
from the obstruction plugged the sampler. The material remaining in the sampler indicated that fill (cap material) graded to native soil in this interval. No further difficulties were encountered in the boring. Silty clay dominates the interval from 15 to $47 \mathrm{ft}$. However, the interval from 17.5 to $18.2 \mathrm{ft}$ contains a notable amount of very fine grained sand. This interval also showed an oily sheen on the grains and had a strong hydrocarbon odor. The odor was not noticed in other intervals of the boring. The silty clay was very sandy just above a silty gravel at $47 \mathrm{ft}$. The silty gravels are limestone, sandstone, and chert. The bedrock was encountered at $51 \mathrm{ft}$.

Test cell 1: Soils in T1B3 consisted of humus to $1 \mathrm{ft}$; followed by fill, consisting of silty clay with scattered sand and gravels to $6 \mathrm{ft}$. The continuous sampler had to be removed from 6 to $8 \mathrm{ft}$ because of a layer of gravel or riprap. Silty clay fill continued from 8-13 ft, this interval also contained coarse sand, wood fragments, and other carbonaceous debris. The interval also exhibited an oily sheen, had a strong hydrocarbon odor from 8 to $10 \mathrm{ft}$, and a sulphurous organic odor from 10 to $13 \mathrm{ft}$. From $13 \mathrm{ft}$ to a total depth of $25 \mathrm{ft}$, the soil consisted of dark gray silty clay. No odors were detected below $13 \mathrm{ft}$.

All the additional boreholes matched T1B3 closely. All had fill to approximately 12 to $14 \mathrm{ft}$. T1B2 and T1B4 had the same gravel layer present from 6 to $8 \mathrm{ft}$ as T1B3. Drilling was difficult and the samplers had to be pulled in order to auger through this zone. Borings T1B1 and T1B5 were drilled with some difficulty from 6 to $8 \mathrm{ft}$, however, the samplers did not have to be removed. All the holes had a very strong hydrocarbon odor with some visible staining from 8 to $10 \mathrm{ft}$. The hydrocarbon odor and staining decreased below $10 \mathrm{ft}$ and was absent for the most part below $13 \mathrm{ft}$. All the borings encountered water at a clepth of 23 to $24 \mathrm{ft}$. Borings T1B1 and T1B2 encountered an oily sludge and perched water from approximately 9 to $10 \mathrm{ft}$. There was enough water and oil present to follow the augers and samplers down to at least $25 \mathrm{ft}$ making the water sample results from $25 \mathrm{ft}$ questionable. There were also some large cobbles or other debris at $10 \mathrm{ft}$ in borings T1B1 and T1B2.

Test cell 2: Soils in T2B 3 consisted of humus to $1 \mathrm{ft}$ followed by a brown silty clay to $6 \mathrm{ft}$. An obstruction was encountered at $6 \mathrm{ft}$, probably cobbles or other riprap. The continuous sampling and drilling continued through the obstruction to a depth of $7 \mathrm{ft}$. The fill material continued from 7 to $10 \mathrm{ft}$. A large obstruction was encountered at $10 \mathrm{ft}$ and the sampler was removed; however, the auger would not penetrate the obstruction. The augers were removed from the boring and the rig was moved $1 \mathrm{ft}$ to the west. The new boring was drilled to $12 \mathrm{ft}$ and drilling was very difficult from 10 to $12 \mathrm{ft}$. The continuous sampler was inserted at $12 \mathrm{ft}$, but sample recovery was low from 12 to $15 \mathrm{ft}$. The fill material appeared to stop at approximately $14 \mathrm{ft}$. Lithology consisted primarily of silty clay from 14 to $47 \mathrm{ft}$, interrupted by a $1-\mathrm{ft}$ zone of peat (wood fragments and decayed organic material) at $23 \mathrm{ft}$. An oily sheen was 
noted in the upper portions of the silt and a slight hydrocarbon odor was present in the peat. Gravelly silt was encountered at $46 \mathrm{ft}$, the bedrock was evident at $48.5 \mathrm{ft}$ and the total depth of the boring was $49 \mathrm{ft}$.

Drilling was very difficult in T2B 1 and T2B2 because of gravel layers at $3 \mathrm{ft}$ in both borings. In boring $\mathrm{T} 2 \mathrm{~B} 2$, the sampler was removed at $4 \mathrm{ft}$ and the soil was gravelly to $10 \mathrm{ft}$ then became softer. The augers were removed from the boring at $11 \mathrm{ft}$ to clean an obstruction from the bit. The obstruction was a portion of a cobble which had obviously been larger than 3 in. A hydrocarbon odor was noted from 8 to $10 \mathrm{ft}$, and the fill extended to approximately $12 \mathrm{ft}$.

Borings T2B4 and T2B5 were drilled without major difficulties. Approximately 5 to $6 \mathrm{ft}$ of cap material was drilled before encountering the dark gray fill as seen in other borings. There was a slight increase in moisture at $10 \mathrm{ft}$ accompanied by a strong hydrocarbon and solvent odor. From 20 to $23 \mathrm{ft}$, visible product was present in T2B4 and the amount of product present had changed the normally cohesive soils to a crumbly mass. There was also a very strong hydrocarbon and solvent odor in T2B4. Boring T2B5 had a moderate hydrocarbon and solvent odor from 20 to $23 \mathrm{ft}$ but there was no visible product and the soil has not been altered as in T2B4. The soil became homogeneous and sticky at approximately 34 to $36 \mathrm{ft}$ in all of the borings. The gravel zone above the sandstone bedrock ranged from 1.5 to $2 \mathrm{ft}$ thick in this cell.

Test cell 3: The soil in T3B3 consisted of humus to $1 \mathrm{ft}$ followed by brown silty clay fill to a depth of $12 \mathrm{ft}$. A slight solvent odor was noted in the lower portion of the fill. From $12 \mathrm{ft}$ to the total depth of $25 \mathrm{ft}$, the lithology was dark gray silty clay with occasional fine grained sands. The solvent odor persisted through these depths and became very strong from 20 to $23 \mathrm{ft}$. Fresh soil faces appeared wet but were actually saturated with product. The soil became wet at $23 \mathrm{ft}$, and the soil was noncohesive below $20 \mathrm{ft}$, probably because the product altered the soil structure. No large gravels, riprap, or other obstructions were encountered.

The fill thickness ranged from 11 to $12 \mathrm{ft}$ in all the boreholes. No odors were present in the fill. The first hint of contamination appeared at approximately $15 \mathrm{ft}$ and borings T3B4 and T3B5 became quite contaminated by $20 \mathrm{ft}$ below ground surface (bgs). There was an oily sheen present from 20 to $25 \mathrm{ft}$ with most of the free product concentrated from 20 to $23 \mathrm{ft}$. The bailer used for collecting the $30 \mathrm{ft}$ water sample was coated in oil upon removal from the augers in boreholes T3B4 and T3B5. 
The free product visible in the silty clay was not as prevalent in borings T3B 1 and $\mathrm{T} 3 \mathrm{~B} 2$ as it was in T3B3, T3B4, and T3B5. A slight oily sheen was visible from 20 to $25 \mathrm{ft}$ but not to the extent observed in the other three boreholes. Soil in all of the borings became saturated between 23 and $24 \mathrm{ft}$ bgs.

Results of laboratory analyses performed on soil samples collected from the T3 cell as part of the MRVS treatability study (West et al. 1995) revealed the following characteristics:

\section{Soil Property}

Unified Soil Classification

Moisture content

Plastic limit

Liquid limit

Dry bulk density

Total organic content

\section{Range}

$\mathrm{CL}$ to $\mathrm{CH}$

$19 \%$ (above the water table), 33\% (below the water table)

18 to $20 \%$

33 to $50 \%$

1.33 to $1.48 \mathrm{~g} / \mathrm{cc}$

0.4 to $0.7 \%$

Test cell 4: The soil in T4B2 consisted of humus to $1 \mathrm{ft}$ followed by dark brown to dark gray silty clay fill to $12 \mathrm{ft}$ bgs. A slight hydrocarbon odor was noted at $10 \mathrm{ft}$. The lithology consisted of silty clay from $12 \mathrm{ft}$ to $45 \mathrm{ft}$ and silty gravel from $45 \mathrm{ft}$ to the sandstone bedrock at $47.5 \mathrm{ft}$. Visible product was noted at $15 \mathrm{ft}$ and the soil was noncohesive and saturated with procluct from 20 to $34 \mathrm{ft}$. Some pore spaces and fracture faces were discernable from 3.4 to $40 \mathrm{ft}$ bgs. Below $40 \mathrm{ft}$, scattered lenses of sand and silt were visible. A strong hydrocarbon and solvent odor was present from 20 to $40 \mathrm{ft}$, and the odor decreases below $40 \mathrm{ft}$. All of the samplers removed from below the $20 \mathrm{ft}$ interval were coated with a brown, oily substance.

Based on field observations, test cell 4. was the most contaminated cell encountered. Test cell 3 is probably as contaminated as T4, especially in boreholes T3B3, T3B4, and T3B5 but since they were only drilled to $25 \mathrm{ft}$ it was difficult to tell. All the holes in T4 had fill to approximately $11 \mathrm{ft}$ with possible re-worked native soil to $15 \mathrm{ft}$. Below $15 \mathrm{ft}$ visible product was present in all borings and a strong hydrocarbon and solvent odor were always noted. By $18 \mathrm{ft}$ bgs, the soil generally became noncohesive and crumbly from the product induced alteration. It was difficult to distinguish the actual water table in all 5 boreholes due to abundant free product. The bailer used to collect the water samples at $30 \mathrm{ft}$ was covered with oil upon removal from the augers. There was definite free product floating on top of the water in the bailer. The product resembled weathered kerosene or jet fuel based on the odor. The soil in all of the boreholes was altered to some degree even below $30 \mathrm{ft}$. Product was visible in all distinguishable fractures or pore spaces above the gravel. A solvent odor was detected in the gravel zone with occasional small pinpoint beads of oil present. Depth 
to bedrock was between 47 and $48 \mathrm{ft}$ in test cell 4 .

Test cell 5: Soil in T5B3 consisted of humus to $1 \mathrm{ft}$, followed by brown to dark-gray, silty clay fill to $8 \mathrm{ft}$ bgs. No gravels larger than $3 / 4 \mathrm{in}$. were encountered. Dark-gray, silty clay was encountered to a total depth of $25 \mathrm{ft}$, the interval from 8 to $10 \mathrm{ft}$ had a reworked appearance. A moderate hydrocarbon odor was noted at $12 \mathrm{ft}$ which became a strong odor at $15 \mathrm{ft}$ and the soil became noncohesive at that depth. The odor and the noncohesive soil was prevalent to $25 \mathrm{ft}$. Free product was present in pore spaces and a brown oily sheen covered all sampling equipment.

Boreholes T5B1, T5B2, T5B4, and T5B5 did not deviate to any great degree from the lithology or contamination that was noted on the log for T5B3. All of the boreholes in test cell 5 had fill to approximately 7 to $8 \mathrm{ft}$. The native soil beneath the fill had a reworked appearance to a depth of 10 to $11 \mathrm{ft}$. No contamination was readily identifiable until about $15 \mathrm{ft}$ bgs. From 15 to $20 \mathrm{ft}$ a slight oily sheen was visible accompanied by a very strong hydrocarbon and solvent odor. The amount of contamination increased rapidly below $20 \mathrm{ft}$ to a level where the soil was saturated with product. The soil structure was highly altered from 20 to $25 \mathrm{ft}$ with most of the product concentrated from 20 to $23 \mathrm{ft}$. The soil was crumbly and little native structure was identifiable in the soil. All of the boreholes were wet at approximately $23 \mathrm{ft}$, however abundant product remained below $23 \mathrm{ft}$. Oil was present in and on the bailer used for water sampling on every borehole except T5B4 and T5B5. Even though no oil was present in or on the bailer there was a strong hydrocarbon and solvent odor in the water.

Of the boreholes in test cell 5, T5B4 and T5B5 were the least contaminated. In reviewing the data from a previous investigation it appears the contamination might be more prevalent in a north to northeast direction from this test cell.

Test cell 6: Boring T6B3 was drilled approximately 18 in. from borehole NEBH-17; therefore, the boring $\log$ from NEBH-17 was used to describe the lithology in this test cell. Soil in NEBH-17 consisted of dark-brown silty clay fill to $14 \mathrm{ft}$, dark-gray, silty clay to $47 \mathrm{ft}$, and a $1 \mathrm{ft}$ layer of gravelly silt to the sandstone bedrock at $48 \mathrm{ft}$. Bedrock was encountered in test cell 6 at depths between 47.5 and $48.5 \mathrm{ft}$. The summary for test cells 3 and 4 also describe the conditions present in test cell 6.

Test cell 7: Soil in T7B3 consisted of humus to 1-ft followed by dark gray silty clay fill to $10 \mathrm{ft}$. Cobbles up to $2 \mathrm{in}$. were recovered in the sampler and drilling was difficult through the gravels, but the sampler did not have to be removed. Dark gray silty clay was encountered from $10 \mathrm{ft}$ to the total depth of $25 \mathrm{ft}$. A moderate hydrocarbon odor was noted at $12 \mathrm{ft}$ becoming a strong odor by $15 \mathrm{ft}$. The soil was altered and noncohesive below 15 with discernable free product. There was an oily sheen on sampling equipment. 
Minor drilling problems were also noted in the remaining four borings in test cell 7. There were a couple of instances where large cobbles kicked the augers off to one side causing some minor deviation problems.

As in test cell 6 there was a concern that the contamination was greater further to the north. Thus, T7B3 was drilled first, then T7B2, and finally T7B4. The rationale was that, if there was a significant change in the amount of contamination in $\mathrm{T} 7 \mathrm{~B} 4$, that being less contamination, then T7B 5 would be moved north of T7B1. As in previous borings, no contamination was detected in the fill. The first visible signs of contamination were again at $15 \mathrm{ft}$. There was visible product in the pore spaces and freshly broken sample faces from 15 to $20 \mathrm{ft}$ were accompanied by a strong hydrocarbon odor. Abundant free product was visible from 20 to $25 \mathrm{ft}$ with the greatest concentrations present from 20 to $23 \mathrm{ft}$. All the borings were wet at approximately 22 to $23 \mathrm{ft}$ bgs. Soil in all the boreholes was noncohesive from 20 to $23 \mathrm{ft}$ due to product related alteratior.

\subsubsection{Contaminant Concentrations}

Levels of TCE and cis-1,2-DCE in individual samples from the pre-treatment characterization are provided in Appendix B. Because no trans-1,2-DCE, 1,1-DCE, or 1,2-DCA were detected in any of the samples, results for these analytes have been omitted from Appendix B. Results of the TCE and cis-1,2-DCE analyses are discussed below.

Shakedown: No contamination above detection limits was discovered in the shakedown test cell.

Test cell 1: Very low levels of TCE: were detected in the test cell 1 soil samples. One sample from $6 \mathrm{ft}$ in boring 3 contained $48 \mathrm{ppb}$ of TCE. Some samples contained $2 \mathrm{ppb}$. No cis-1,2-DCE was detected in the soil in this test cell. No detectable contaminants were discovered in the groundwater.

Test cell 2: Levels of TCE up to $133 \mathrm{ppm}$ ( $9 \mathrm{ft}$ in B5) were discovered in the shallow soil samples. Most of these shallow soil samples contained concentrations between $100 \mathrm{ppb}$ and $40 \mathrm{ppm}$. No significant contamination was discovered below a depth of $16 \mathrm{ft}$. No cis-1,2-DCE was detected in the soil in this test cell. 
However, the groundwater samples collected at all depths in all five borings contain at least some TCE.

Test cell 3: Levels of TCE up to $527 \mathrm{ppm}$ ( $25 \mathrm{ft}$ in B4) were discovered in test cell 3. Contamination in this test cell is at a lower depth than in test cell 2 and is more widespread. Boring 1 has lower levels of TCE in the deeper samples. Only one sample (from boring T3B1 at $21 \mathrm{ft}$ ) had cis-1,2-DCE at a concentration of $59 \mathrm{ppm}$. The groundwater samples collected at $25 \mathrm{ft}$ contain TCE but no cis-1,2-DCE.

Test cell 4: Levels of TCE in test cell 4 range up to $1,666 \mathrm{ppm}$ at $30 \mathrm{ft}$ in B4. Soil contamination is highest between about 20 and $40 \mathrm{ft}$. The contamination levels tend to be higher in the shallow soils at the north end and higher in the deeper portion of the south end of the test cell. However, all samples below about $10 \mathrm{ft}$ in all borings contain detectable levels of TCE. The presence of cis-1,2-DCE in soil was limited to a handful of samples ranging up to $80 \mathrm{ppm}$ in concentration. Groundwater samples from all depths in all borings contain high levels of TCE.

Test cell 5: Although these borings were only drilled to $25 \mathrm{ft}$, the highest levels of contamination are above that total depth. Levels of TCE in soil range up to $501 \mathrm{ppm}$ ( $15 \mathrm{ft}$ in B1) with the highest levels of contamination between 15 and $20 \mathrm{ft}$. However, samples from boring 5 at those depths ranged from nondetectable to only $238 \mathrm{ppb}$. The contamination at those depths does not appear to extend south of the test cell. The presence of cis-1,2-DCE in soil was limited to two samples ranging up to 242 $\mathrm{ppm}$ in concentration. Groundwater samples collected at $25 \mathrm{ft}$ indicated TCE contamination in all borings. The sample from boring 5 was the lowest.

Test cell 6: The highest level of TCE in a soil sample was discovered in this cell, $3,800 \mathrm{ppm}$ at $31 \mathrm{ft}$ in T6B5. Soil contamination is highest from about 20 to $40 \mathrm{ft}$ in the southern portion of the cell. Although contamination exists in all five borings at depths from below 12 to total depth, no cis-1,2-DCE was detected in this test cell. Groundwater samples from all levels in all borings contained high levels of TCE.

Test cell 7: Levels of TCE contamination in soil samples ranged from 10 to $219 \mathrm{ppm}$. This level of contamination was concentrated in the 15 to $20 \mathrm{ft}$ depths in all borings. Levels of contamination below and above this interval were much lower. No cis-1,2DCE was detected in this test cell. Groundwater samples collected at $25 \mathrm{ft}$ indicated TCE contamination in all borings. 


\section{MONITORING AND MEASUREMENT ACTIVITIES}

Monitoring and measurement of specific performance parameters were performed with a DAS. The parameters collected by the DAS are presented in Table 3.1.

Table 3.1. DAS parameters

\begin{tabular}{ll}
\hline Data Parameter & Unit of Measurement \\
\hline Auger depth & Ft per unit time \\
Off-gas VOC & Total VOCs in ppm with a flame ionization detector \\
& (FID) \\
Source temperature (air) & Centigrade \\
Off-gas temperature & Centigrade \\
Off-gas pressure & Pounds per square in. (psi) \\
Off-gas volume & Cubic ft/min (cfm) \\
Soil temperature & Centigrade \\
\hline
\end{tabular}

\subsection{Gas Analyses for Target VOCs}

During mixing operations off-gas vapor was continuously monitored with a Baseline ${ }^{\mathrm{TM}}$ 1015A total gas analyzer equipped with a FID. The FID readings, which represent total VOC concentrations in the off gas, were recorded by the DAS and are presented as graphic plots in Appendix C. Subsamples of the vapor stream were collected in septa-equipped glass sampling bulbs for analysis by direct injection into the GC. Results of the off-gas VOC analyses are presented in Table 3.2.

The finding that TCE was the only compound detected in the off-gas was not unexpected considering its predominance over the other target compounds cis- $\&$ trans-1,2-DCE in the pre-treatment soil and groundwater data presented in Appendix B. Another point of interest is the relationship between the total VOCs measured with the FID and the TCE concentration from GC analysis. Consistently higher total VOC concentrations are attributed to the presence of significant amounts of petroleum hydrocarbons and semivolatile compounds (U.S. DOE 1994) which were not targeted for GC analysis. Due to the relatively unknown composition of the offgas, previously discussed problems with the off gas tubing and a limited number of off gas samples, the value of the total VOC readings for the evaluation of effectiveness of the various reagents' ability to reduce VOC mass is limited. However, in a more qualitative sense, the off gas FID data is useful in attributing the degree of volatilization associated with the mixing operations and indicate that the initial drilling of each column consistently produced the highest total VOCs in the off gas. 
Table 3.2. Off-gas sample results

\begin{tabular}{||c|c|l|l|c|c||}
\hline $\begin{array}{c}\text { Sample } \\
\text { location }\end{array}$ & $\begin{array}{c}\text { Depth, } \\
\mathrm{ft}\end{array}$ & \multicolumn{1}{|c|}{ Date } & \multicolumn{1}{|c|}{ Time } & $\begin{array}{c}\text { Total VOC, } \\
\text { ppm }\end{array}$ & TCE, ppm \\
\hline T3C1 & 10.0 & $7-11-96$ & $14: 55$ & 4,500 & 906 \\
\hline T3C1 & 19.0 & $7-11-96$ & $15: 10$ & 8,000 & 520 \\
\hline T3C1 & 14.0 & $7-11-96$ & $15: 32$ & 1,400 & 64 \\
\hline T3C1 & 8.0 & $7-11-96$ & $17: 04$ & 1,600 & 194 \\
\hline T3C2 & 24.0 & $7-11-96$ & $18: 00$ & 6,700 & 401 \\
\hline T3C2 & 14.0 & $7-11-96$ & $18: 23$ & 1,300 & 148 \\
\hline T3C2 & 8.0 & $7-11-96$ & $18: 31$ & 2,000 & 29 \\
\hline T3C3 & 12.0 & $7-11-96$ & $11: 06$ & 7,500 & ND \\
\hline T3C3 & 16.0 & $7-11-96$ & $11: 11$ & 15,000 & 784 \\
\hline T3C3 & 16.0 & $7-11-96$ & $14: 03$ & 2,000 & 478 \\
\hline T4C1 & 12.0 & $7-15-96$ & $15: 09$ & 12,000 & 1,112 \\
\hline T4C1 & 35.0 & $7-15-96$ & $15: 25$ & 12,000 & 656 \\
\hline T4C2 & 21.0 & $7-16-96$ & $16: 24$ & 22,000 & 1,416 \\
\hline T4C2 & 24.0 & $7-16-96$ & $16: 26$ & 13,000 & 1,093 \\
\hline T4C2 & 42.0 & $7-16-96$ & $16: 38$ & 2,200 & 215 \\
\hline T5C1 & 14.0 & $7-13-96$ & $11: 26$ & 13,000 & 963 \\
\hline T5C1 & 21.0 & $7-13-96$ & $11: 31$ & 15,000 & 620 \\
\hline T5C2 & 13.0 & $7-13-96$ & $14: 39$ & 6,400 & 539 \\
\hline T5C2 & 11.0 & $7-13-96$ & $14: 42$ & 15,000 & 286 \\
\hline T5C3 & 23.0 & $7-12-96$ & $17: 10$ & 8,000 & 52 \\
\hline T5C3 & 5.0 & $7-12-96$ & $17: 26$ & 1,200 & 11 \\
\hline T7C1 & 20.0 & $7-20-96$ & $10: 11$ & 1,700 & 12 \\
\hline T7C2 & 20.0 & $7-20-96$ & $14: 56$ & 600 & 12 \\
\hline \hline
\end{tabular}




\section{RESULTS AND DISCUSSION}

Figure 4.1 shows the locations of the bioaugmentation cell (T3), two $\mathrm{KMnO}_{4}$ cells (T4 and T5), and the MRVS cell (T7) that were treated as part of the DSM demonstration. Columns in the T3, T5 and T7 cells were mixed to a depth of $25 \mathrm{ft}$ bgs while the columns in the T4 cell were mixed to a depth of $47 \mathrm{ft}$ bgs. The following sections present the operational information and post-treatment sampling results in chronological fashion.

\subsection{DSM/Bioaugmentation Demonstration Results}

\subsubsection{Bacteria/Bionutrient Background Information}

A treatability study examining the biodegradation of TCE in KCP soil using Burkholderia cepacia $\mathrm{G} 4 \mathrm{PR}_{301}$, (referred to as $\mathrm{G} 4$ in the following) was completed in 1995. The results of the treatability study, presented in Appendix D, indicated that in $48 \mathrm{hrs}$ a $10 \%$ inoculum of G4 could degrade $99.8 \%$ of the TCE present in the 1 and 5 ppm samples. Similarly, the same G4 could degrade $87.4 \%$ of the TCE present in the $10 \mathrm{ppm}$ sample in the same time frame.

Bioremediation, with the technique being applied in this project, is most effective at in TCE concentrations up to $10 \mathrm{ppm}$. As previously discussed, the planned location (T7 cell) for demonstrating DSM and bioaugmentation contained an average of 20 $\mathrm{mg} / \mathrm{kg}$ TCE. However, the initial shakedown activities at the site flooded the T7 cell with approximately $4 \mathrm{ft}$ of water and sediment. Because the bacteria culture had been inoculated and was time-sensitive, the bioaugmentation location had to be relocated to the T3 cell (Fig. 4.2), a site with significantly higher average TCE concentrations (126 mg/kg). As previously discussed, the lack of contamination and suggested concrete debris material identified in the T1 and T2 cells during pretreatment characterization, prevented their use for the bioaugmentation demonstration.

The decision to relocate the bioaugmentation demo to the $\mathrm{T} 3$ cell resulted from a combination of factors. While the toxic effects on the bacteria from the higher TCE levels were predictable, the risk of creating a slurry with liquid to soil ratio $>1$, however was considered potentially more damaging by the principal investigator due to relatively low enzyme activity of the bacteria solution-adding more water would dilute it further. Moreover, the lack of a dry shake down added uncertainty to the drilling equipment's ability to reach $25 \mathrm{ft}$ with air alone. Thus, the suggestion that

additional water might be needed to complete the drilling and the inability to control 


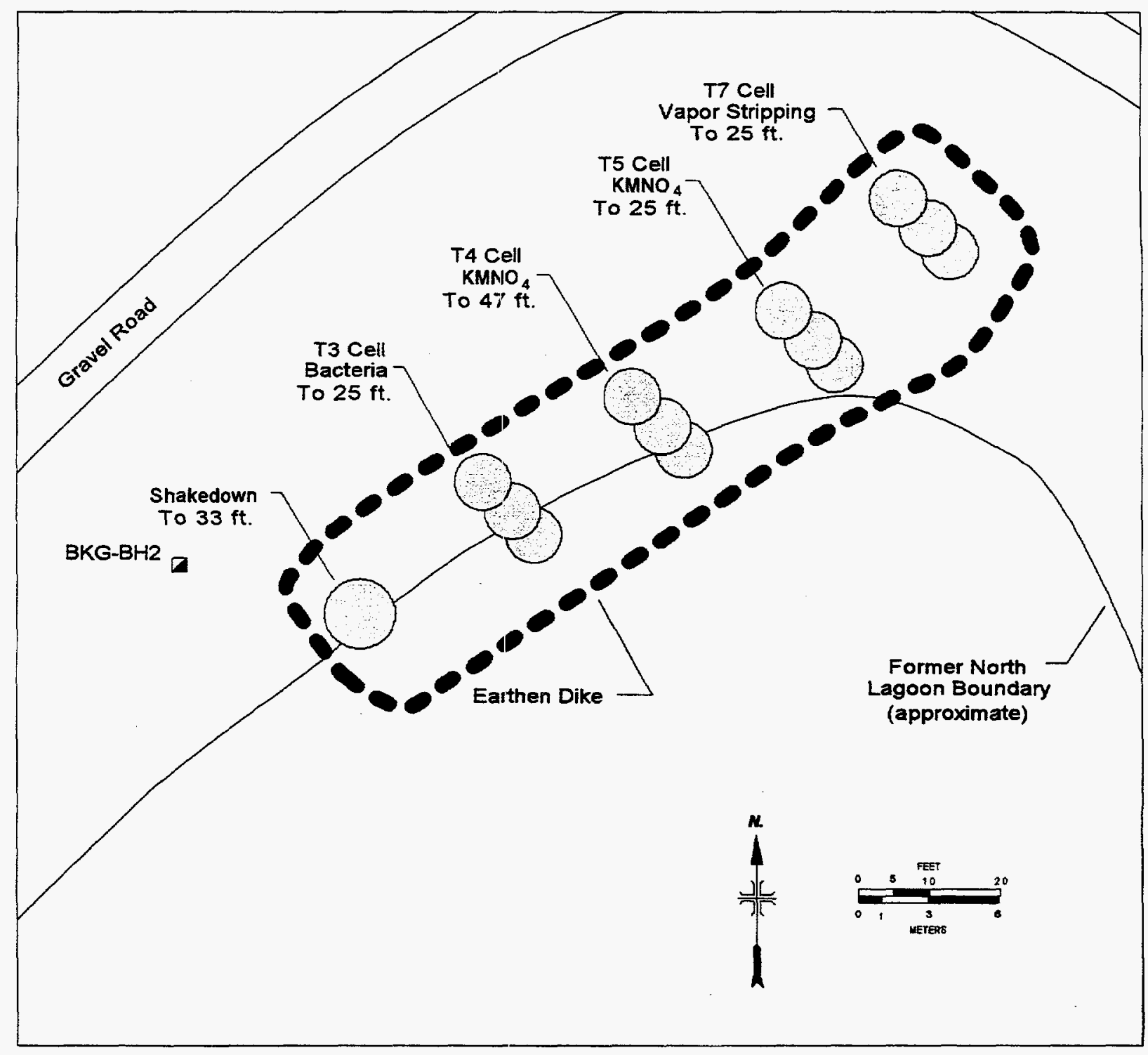

OSM012

Deep Soil Mixing Location

D] Background Soil Boring Location

Fig. 4.1. Test cell locations within the Deep Soil Mixing area. 


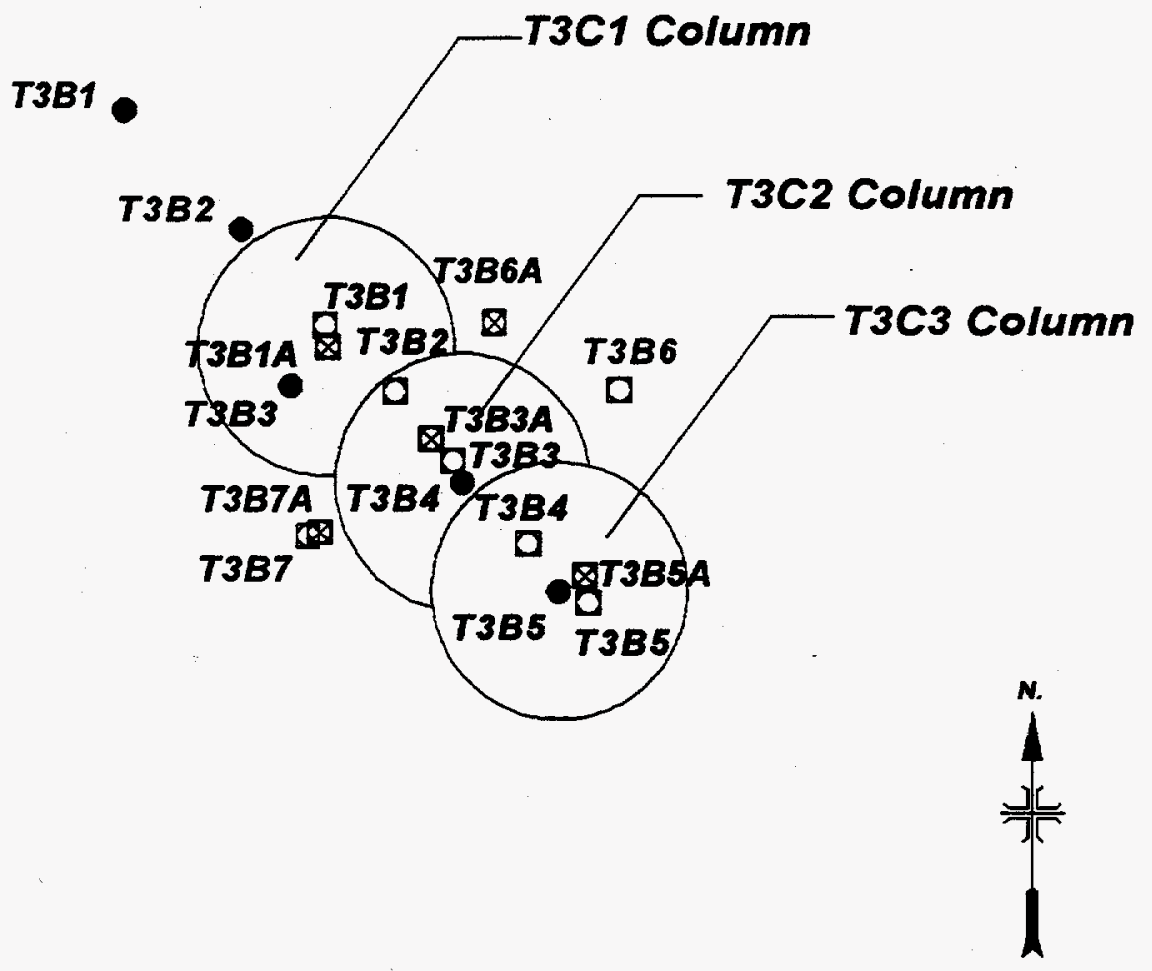

- Pre-characterization borehole

a Post-characterization borehole

$\otimes 7$ to 10 day post-characterization borehole

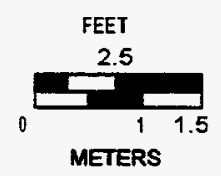

SM

Fig. 4.2. T3 cell layout with soil boring locations. 
the volume of pooled water that would seep in under the vacuum hood if drilling were performed at the T7 cell, precipitated the decision to use the T3 cell.

G4 was initially grown at ORNL in two large reactors ( 5 gal) using a basal salts media (BSM) (Hareland et al. 1975) with $20 \mathrm{mM}$ glucose as the sole carbon source. On July 7 , five gal of active culture (enzyme specific activity $>3$ ) were transferred to large sterilized jugs, put on ice and shipped to KCP to be used as an inoculum. Two 500gal reactors (front, $\mathrm{F}$, and back, B) ecpuipped with a stirring/air delivery mechanism (BioSystems Technology, Blacksburg, Virginia) were filled with municipal drinking water on July 8 . Nutrients were slowly added until dissolved. Nutrients included glucose at $20 \mathrm{mM}$ and the BSM. Finally, the G4 inoculum was mixed in. Each reactor contained $450 \mathrm{gal}$ of bacteria/nutrient solution.

G4 growth, enzyme specific activity, and glucose concentrations were monitored daily and at the time of addition into the subsurface. G4 growth, measured by an increase in optical density (OD) of the solution, was determined using a spectrophotometer (Spectronic 20D, Milton Roy Co.) operating at a wavelength of $600 \mathrm{~nm}$. Expression of toluene ortho-monooxygenase, the enzyme responsible for TCE degradation, was measured using a TFMP (trifluoromethylphenol or m-hydroxy benzotrifluoride) oxidation assay. The rate of production of TFHA (7,7,7-trifluoro-2-hydroxy-6-oxo2,4-heptadienoic acid), a yellow product, from TFMP oxidation correlates to the potential rate of TCE degradation by the enzyme (Shields et al. 1991, Shields and Reagin 1992). Glucose concentrations were determined using a glucose assay kit (Sigma Diagnostics, St. Louis, Missouri).

On July 9 , the OD was calculated to be 0.11 for both reactors with no enzyme activity detected and a glucose concentrations of $10-11 \mathrm{mM}$. It is important to note that treatability studies have indicated that enzyme activity cannot be detected for an OD less than 2 using currently available colormetric methods. Although the OD is representative of bacterial density, non detectable enzyme activity does not mean the enzyme is not present, it is simply below very crude colormetric detection limits. Therefore, the lack of detectable enzyme activity does not affect the bacteria's viability to degrade TCE. The ODs for both reactors continued to be low (less than 0.1 ) on July 10 with no enzyme activity detected and a glucose concentration of 12 and $15 \mathrm{mM}$. Based on this information, both bioreactors were inoculated with an additional G4 stock that was brought to KCP by BioSystems Technology. On July 11 , the day of the demonstration, both reactors revealed denser microbial cultures with a significant amount of foaming. The ODs were $0.17(\mathrm{~F})$ and $0.30(\mathrm{~B})$ and the glucose concentrations were 0.7 to $0.85 \mathrm{mM}$, suggesting that $\mathrm{G} 4$ was growing. However, because the ODs were still below 2 , the colorometric assay was not able to measure the enzyme activity (below detection limits). 


\subsubsection{Bioaugmentation Operational Information}

DSM/Bioaugmentation was conducted July 11 in three overlapping test columns (T3C1, $\mathrm{T} 3 \mathrm{C} 2$, and $\mathrm{T} 3 \mathrm{C} 3$ ) with 8-ft diameters and 25-ft depths (Fig. 4.2). Column T3C3 was treated first and served as the shake-down test column for drilling with air. This was followed by column $\mathrm{T} 3 \mathrm{C} 1$, and finally column $\mathrm{T} 3 \mathrm{C} 2$. Following are brief summaries of process operations at each column presented in chronological order.

\section{T3C3 Column}

Elapsed time

0 to $55 \mathrm{~min}$

55 to $66 \mathrm{~min}$

66 to $86 \mathrm{~min}$

86 to $174 \mathrm{~min}$

174 to $197 \mathrm{~min}$

197 to $205 \mathrm{~min}$

205 to $219 \mathrm{~min}$

219 to $224 \mathrm{~min}$
Process description

An 8-ft diameter hole drilled with air (700 to $1000 \mathrm{cfm}$ ) to a depth of $25 \mathrm{ft}$, off gas tubing is collapsed throughout demonstration.

Prepare for mixing.

344 gal of bacteria solution mixed in between $24 \mathrm{ft}$ and $3 \mathrm{ft}$.

Repair torn shroud seal.

Mix column with air ( 800 to $1100 \mathrm{cfm}$ ) from surface to $24 \mathrm{ft}$.

Mix column with air $(800$ to $1100 \mathrm{cfm}$ ) from $24 \mathrm{ft}$ to surface.

Mix column with air ( 800 to $1100 \mathrm{cfm}$ ) from surface to $24 \mathrm{ft}$.

Mix column with air ( 800 to $1100 \mathrm{~cm})$ from $24 \mathrm{ft}$ to surface, end of mix.

Following the mixing of column $\mathrm{T} 3 \mathrm{C} 3$, the mixing apparatus was moved and located over column $\mathrm{T} 3 \mathrm{C} 1$ at the northern end of the $\mathrm{T} 3$ cell.

\section{T3C1 Column}

Elapsed time

0 to $47 \mathrm{~min}$

47 to $64 \mathrm{~min}$

64 to $140 \mathrm{~min}$ 140 to $165 \mathrm{~min}$

\section{Process description}

An 8-ft diameter hole drilled with air (800 to $1100 \mathrm{cfm}$ ) to a depth of $25 \mathrm{ft}$, off gas tubing collapses immediately and remains that way.

266 gal bacteria solution mixed in between 23 and $2.5 \mathrm{ft}$.

Rig repair (shroud seal replaced).

Mix column with air $(800$ to $1100 \mathrm{cfm})$ from 1.5 to $23 \mathrm{ft}$. 
165 to $173 \mathrm{~min}$

Mix column with air ( 800 to $1100 \mathrm{cfm})$ from 23 to $1.5 \mathrm{ft}$, end mix.

Following the mixing of column $\mathrm{T} 3 \mathrm{C} 1$, the mixing apparatus was moved and located over column $\mathrm{T} 3 \mathrm{C} 2$ in the center of the $\mathrm{T} 3$ cell.

\section{T3C2 Column}

Elapsed time Process description

0 to $20 \mathrm{~min}$

An 8-ft diameter hole drilled with air (700 to $1000 \mathrm{cfm}$ ) to a depth of $25 \mathrm{ft}$, off gas tubing remains collapsed for entire demonstration.

20 to $31 \mathrm{~min}$ Prepare for mixing.

31 to $38 \mathrm{~min}$ 279 gal of bacteria solution mixed in between $24 \mathrm{ft}$ to surface.

38 to $51 \mathrm{~min}$

Mix column with air ( 800 to $1100 \mathrm{cfm}$ ) from surface to $24 \mathrm{ft}$.

51 to $57 \mathrm{~min} \quad$ Mix column with air (800 to $1100 \mathrm{cfm}$ ) from $24 \mathrm{ft}$ to surface.

57 to $59 \mathrm{~min} \quad$ Clear ports on auger blade, end mix.

The most significant consequence of the previously discussed problems with tearing of the shroud seal during the mixing of the $\mathrm{T} 3 \mathrm{C} 3$ and $\mathrm{T} 3 \mathrm{C} 1$ columns is the time lost which would have been used for additional mixing. Additionally, the collapsed off gas tubing prevented the calculation of the air volume being removed from the shroud as well as the ensuing estimation of contaminant mass in the off gas.

Table 4.1 lists the key operational data from the bioaugmentation treatment cells.

Table 4.1. Bioaugmentation operational data

\begin{tabular}{lllllll}
\hline $\begin{array}{l}\text { Treatment } \\
\text { column }\end{array}$ & $\begin{array}{l}\text { Mix } \\
\text { date }\end{array}$ & $\begin{array}{l}\text { Bacteria } \\
\text { added, } L(\text { gal })\end{array}$ & $\begin{array}{l}\text { No. of } \\
\text { Passes }\end{array}$ & $\begin{array}{l}\text { Bacteria solution } \\
\text { to soil ratio }\end{array}$ & $\begin{array}{l}\text { G4 bacteria } \\
\text { OD }\end{array}$ & Glucose, mM \\
\hline & & & & & & \\
T3C1 & $7-11-96$ & $1007(266 \mathrm{gal})$ & 2 & 0.028 & $0.17 / 0.30$ & $0.7 / 0.85$ \\
T3C2 & $7-11-96$ & $1056(279 \mathrm{gal})$ & 2 & 0.032 & $0.17 / 0.30$ & $0.7 / 0.85$ \\
T3C3 & $7-11-96$ & $1302(344 \mathrm{gal})$ & 3 & 0.037 & $0.17 / 0.30$ & $0.7 / 0.85$ \\
\end{tabular}

OD: optical density

The bacteria/bionutrient solution liquid to soil volume ratios presented in Table 4.1 were purposely kept low to prevent the creation of slurry-like conditions in the T3 cell. Although a liquid to soil volume ratio of 1 had been used in the treatability study presented in Appendix D, it was apparent from the lesson learned during the wet 
shakedown that this ratio could not be achieved in the field without surface flooding. The respective bacteria solution to soil ratios for each column were calculated by dividing the volume of bacteria solution added to each column by the volume of soil in each column including void space $\left(35,612,649 \mathrm{~cm}^{3}\right)$. To account for the overlap region in the $\mathrm{C} 2$ column, the ratios for the $\mathrm{C} 1$ and $\mathrm{C} 3$ columns were weighted by $30 \%$ each and added to that of the $\mathrm{C} 2$ column.

Due to the close proximity of the columns in the bioaugmentation cell, post-treatment sampling could not safely be conducted until all three columns had been mixed. This resulted in a minimum delay of two days between mixing and sampling. Posttreatment sampling information for each soil boring in the $\mathrm{T} 3$ cell is presented in Table 4.2 .

Table 4.2. Bioaugmentation sampling information

\begin{tabular}{|c|c|c|c|}
\hline Soil boring & Associated column & Sampling date & Days after mixing \\
\hline T3B1 & T3C1 & $7 / 13 / 96$ & 2 \\
\hline T3B2 & T3C1/T3C2 & $7 / 13 / 96$ & 1.8 \\
\hline T3B3 & T3C2 & $7 / 13 / 96$ & 2.0 \\
\hline T3B4 & T3C2/T3C3 & $7 / 14 / 96$ & 2.5 \\
\hline T3B5 & T3C3 & $7 / 14 / 96$ & 2.6 \\
\hline T3B6 & NA & $7 / 14 / 96$ & 2.7 \\
\hline 73B7 & NA & $7 / 14 / 96$ & 2.7 \\
\hline T3B1A & T3C1 & $7 / 20 / 96$ & 9.0 \\
\hline T3B3A & T3C2 & $7 / 20 / 96$ & 9.0 \\
\hline T3B5A & T3C3 & $7 / 20 / 96$ & 9.0 \\
\hline T3B8A & NA & $7 / 22 / 96$ & 11.0 \\
\hline T3B9A & NA & $7 / 22 / 96$ & 11.0 \\
\hline
\end{tabular}

$\mathrm{NA}=$ not applicable

The following sections present the result of the various analyses performed on the post-treatment soil samples collected from the bioaugmentation treatment cell T3. 


\subsubsection{Post-Treatment VOC Results from Bioaugmentation Cell}

It should be noted that the post-treatment boring locations were not intended to replicate the pre-treatment borings due to the redistributing effects of the mixing action. The post-treatment samples were, however, collected in similar fashion and locations as the pre-treatment samples. Furthermore, the inherent heterogeneity in the pre-treatment soil sample data combined with the redistribution of soil characteristics in the post-treatment soil sample data resulting from the mixing effects, required that the data sets be averaged to provide useful interpretation of the treatment effectiveness. The pre- and post-treatment soil boring locations for the T3 cell are presented in Fig. 4.2. The pre- and post-treatment VOC results for the T3 cell are presented in Appendices B and E respectively. Using these data, pre- and posttreatment average TCE concentrations in soil for the T3 cell have been averaged and are presented in Table 4.3. It should be noted that the only pre-treatment sample from the T3 cell with detectable levels of cis-1,2-DCE was outside the zone mixed during the DSM. No cis-1,2-DCE was detected in any of the post-treatment samples from the T3 cell. Thus, the VOC mass removal efficiency discussion is limited to TCE only.

The average TCE concentration for each soil boring was calculated by summing the depth-specific TCE values and dividing by the number of depth intervals in each boring.

Table 4.3. Pre- and post-treattment average TCE concentrations in T3 Cell borings

\begin{tabular}{||l|l|l|l|l|l|l|l|l|l|l|l|l|l||}
\hline \multicolumn{3}{|c|}{ T3C1 Column } & \multicolumn{3}{c|}{ T3C2 Column } & \multicolumn{3}{c|}{ T3C3 Column } \\
\hline $\begin{array}{l}\text { Pre- } \\
\text { treat } \\
\text { boring } \\
\text { No. }\end{array}$ & $\begin{array}{l}\text { Aver- } \\
\text { age } \\
\text { TCE, } \\
\mathrm{mg} / \mathrm{kg}\end{array}$ & $\begin{array}{l}\text { Post- } \\
\text { treat } \\
\text { boring } \\
\text { No. }\end{array}$ & $\begin{array}{l}\text { Aver- } \\
\text { age } \\
\mathrm{TCE}, \\
\mathrm{mg} / \mathrm{kg}\end{array}$ & $\begin{array}{l}\text { Pre- } \\
\text { treat } \\
\text { boring } \\
\text { No. }\end{array}$ & $\begin{array}{l}\text { Aver- } \\
\text { age } \\
\text { TCE, } \\
\mathrm{mg} / \mathrm{kg}\end{array}$ & $\begin{array}{l}\text { Post- } \\
\text { treat } \\
\text { boring } \\
\text { No. }\end{array}$ & $\begin{array}{l}\text { Aver- } \\
\text { age } \\
\mathrm{TCE}, \\
\mathrm{mg} / \mathrm{kg}\end{array}$ & $\begin{array}{l}\text { Pre- } \\
\text { treat } \\
\text { boring } \\
\text { No. }\end{array}$ & $\begin{array}{l}\text { Aver- } \\
\text { age } \\
\text { TCE, } \\
\mathrm{mg} / \mathrm{kg}\end{array}$ & $\begin{array}{l}\text { Post- } \\
\text { treat } \\
\text { boring } \\
\text { No. }\end{array}$ & $\begin{array}{l}\text { Aver- } \\
\text { age } \\
\text { TCE, } \\
\mathrm{mg} / \mathrm{kg}\end{array}$ \\
\hline T3B3 & 146.3 & T3B1 & 75.3 & T3B4 & 150.7 & T3B2 & 64.0 & T3B5 & 80.3 & T3B4 & 74.8 \\
\hline & & T3B2 & 64.0 & & & T3B3 & 57.7 & & & T3B5 & 122.0 \\
\hline
\end{tabular}

The average TCE concentrations for each pre-treatment boring in each of the T3 columns shown in Table 4.3 were then averaged to arrive at an average pre-treatment TCE concentration for each column. The respective average pre-treatment TCE concentrations for the $\mathrm{C} 1, \mathrm{C} 2$ and $\mathrm{C} 3$ columns are 146,151 , and $80 \mathrm{mg} / \mathrm{kg}$ - which yield an average pre-treatment TCE concentration of $126 \mathrm{mg} / \mathrm{kg}$ for the T3 cell. The mass of soil for the T3 cell was calculated using three $25-\mathrm{ft}$ deep columns with $8 \mathrm{ft}$ 
diameters, a $60 \%$ overlap for the center column, a particle density of $2.65 \mathrm{~g} / \mathrm{cm}^{3}$ and an estimated porosity of $30 \%$. The resulting mass of soil in the T3 cell is $158,548 \mathrm{~kg}$ which when multiplied by the average TCE concentration of $126 \mathrm{mg} / \mathrm{kg}$ yields a total pre-treatment TCE mass of $20 \mathrm{~kg}$ in the T3 cell.

The average TCE concentrations from each of the post-treatment soil borings in the T3 columns shown in Table 4.3 were treated in the same fashion and yield respective average post-treatment TCE concentrations for the $C 1, C 2$ and $C 3$ columns of 60,65 and $106 \mathrm{mg} / \mathrm{kg}$ which yield an average post-treatment TCE concentration of $77 \mathrm{mg} / \mathrm{kg}$ for the T3 cell. The estimated total mass of post-treatment TCE in the T3 cell is calculated to be $12.2 \mathrm{~kg}$ using the same column dimensions and previously mentioned parameters. Comparing the pre- and post-treatment values of 20 and $12.2 \mathrm{~kg} \mathrm{TCE}$ indicates an overall removal rate of $39 \%$ or $7.8 \mathrm{~kg}$ of TCE from the T3 cell.

While the $39 \%$ reduction in TCE mass falls below the overall treatment objective of $70 \%$, it is useful to note that TCE concentrations verify that VOC reductions did occur. Considering that toxic effects on the bacteria from the high TCE concentrations were expected, the reported reduction in mass of TCE is significant. It is also useful to note that different TCE mass reductions could be represented with the same data set. For example, the values could be calculated on a per column basis rather than a per cell basis and show that one column (T3C3) where the posttreatment TCE exceeds the pre-treatment TCE mass. However, due to the previously discussed aspects associated with inherent heterogeneity in soil sampling and the redistribution of soil characteristics introduced by the soil mixing process, it is difficult to draw any significant conclusion from this approach. Moreover, the bulk of the pre-and post-treatment data from the $\mathrm{T} 3$ cell suggests that treatment did occur and, thus, indicate that treatment of the data on a per-cell basis is appropriate.

Post-treatment groundwater samples collected after installing piezometers in the boreholes at locations T3B1, T3B3, and T3B5, yielded TCE concentrations of 26, 48, and $<0.005 \mathrm{mg} / \mathrm{L}$ respectively. These results produce an average post-treatment TCE concentration of $37 \mathrm{mg} / \mathrm{L}$ for the $\mathrm{T} 3$ cell groundwater which can be compared to an average pre-treatment groundwater TCE concentration of $231 \mathrm{mg} / \mathrm{L}$. However, it should be noted that the groundwater sample from the C3 column (T3B5) had a $\mathrm{KMnO}_{4}$ concentration of $1.1 \mathrm{wt} \%$ as a result of mixing in the adjacent $\mathrm{T} 4$ cell. Interestingly, the post-treatment T3B5 groundwater sample was the only one within the biotreatment cells in which no TCE was detected. 


\subsubsection{Biodegradation vs Vapor Stripping}

The amount of TCE stripped from the subsurface from the initial drilling and subsequent mixing of the T3 columns is difficult to quantify for reasons previously discussed. First, a limited number of off gas samples were analyzed with the GC (see Table 3.2). Second, the presence of other organic compounds (hydrocarbons and semivolatiles) in the off gas stream limit the value of the total VOC recorded by the FID for this purpose. Third, the lack of reliable off gas temperature and volume data due to previously discussed problems with the collapsed off gas tubing, make this estimation untenable.

While it is obvious that the initial drilling of the cells using 800 to $1000 \mathrm{cfm}$ of air was responsible for the volatilization of TCE, it is apparent from the DAS graphic plots presented in Appendix $C$, that the subsequent passes with bacteria and air triggered less volatilization. The peak total VOCs recorded with the FID range from 10,000 ppm in $\mathrm{T} 3 \mathrm{C} 1$ to $19,000 \mathrm{ppm}$ in $\mathrm{T} 3 \mathrm{C} 2$. The peaks were all associated with the initial drilling of the columns and correspond to a depth of about $20 \mathrm{ft}$ bgs where some of the highest TCE concentrations were identified in the pre-treatment borings (Appendix B). The effects of stripping following the initial drilling with air appear to taper off considerably as the total VOCs measured in subsequent passes using air after bioaugmentation range from $2000 \mathrm{ppm}$ in $\mathrm{T} 3 \mathrm{C} 1$ to $5000 \mathrm{ppm}$ in T3C3.

The amount of TCE degraded by G4 only could not be calculated directly from the off gas samples due to previously discussed problems with collapses in the off gas tubing. However, treatability studies have shown that $100 \mu \mathrm{g}$ of TCE could be degraded by $1 \mathrm{~mL}$ of $\mathrm{G} 4$ (at OD of 2) in $36 \mathrm{hrs}$. Assuming no loss of enzyme activity during scale-up, 300 gal of $\mathrm{G} 4$ at an $\mathrm{OD}=2$ would have degraded approximately 115 $\mathrm{g}$ of TCE. At the time of the first sampling event (i.e., 24 to $48 \mathrm{hrs}$ after treatment), 2.5 and $1.8 \mathrm{~kg}$ of TCE were removed from Column T3C1 and T3C2, respectively. These amounts exceed the amount of TCE that could have been removed by $\mathrm{G} 4$ alone which suggest air stripping is responsible for a portion of the TCE mass removal.

\subsubsection{Microbial Monitoring Results}

Geoprobe soil cores were collected from inside and outside the three columns and shipped on ice to ORNL for microbiological analyses. Experiments determined the effects of bacterial addition and DSM treatment on the indigenous microbial population and survivability of G4 in the subsurface, as well as the potential distribution/migration of these microorganisms outside the treatment zone. Analyses consisted of blending $1 \mathrm{gm}$ in a phosphate buffer saline. Serial dilutions of the blended samples were inoculated onto a non-selective growth media of $1 \%$ PTYG (peptone-tryptone-yeast extract-glucose) and a selective media of lactate+BSM (a G4 specific medium). Cultures that phenotypically resembled G4 underwent analyses 
using the Biolog system (Bochner 1989). Finally, TCE degradation was investigated upon reacclimation, in the laboratory, of selected microorganisms isolated from the soil samples.

The microbiological experiments determined the presence of $\mathrm{G} 4$ at depths up to 13.5 $\mathrm{ft}$ bgs in the soil samples collected in the $\mathrm{T} 3 \mathrm{C} 1$ and $\mathrm{T} 3 \mathrm{C} 2$ columns during the first sampling event (two days). However, bacterial counts suggest that $\mathrm{G} 4$ had a low survivability in the subsurface matrix as depth increased. The highest numbers of microorganisms were observed in boreholes T3B1, T3B2, and T3B3 (depths between 5.5 and $10 \mathrm{ft}$ ) with CFU (colony forming unit) numbers ranging from 2.2 to $3.6 \times 10^{4}$ $/ \mathrm{g}$ of soil. Interestingly, the post-treatment TCE concentrations for the previous depths in the latter boreholes ranges from 5 to $26 \mathrm{mg} / \mathrm{kg}$ (Appendix E). For depths below $13.5 \mathrm{ft}$, CFUs were $<1 \times 10^{2} / \mathrm{g}$ of soil and post-treatment TCE concentrations up to $279 \mathrm{mg} / \mathrm{kg}$ were reported (Appendix E). For Column T3C3, CFUs were $<1$ $\times 10^{2}$ for all depths (boreholes T3B4 and T3B5). Several factors contribute to the low survivability of G4, including very high TCE concentrations with increasing depths and decreasing oxygen concentrations in the subsurface.

At the time of the second sampling (10 days post-treatment), $\mathrm{G} 4$ was still recoverable from Column $\mathrm{T} 3 \mathrm{C} 1$ and $\mathrm{T} 3 \mathrm{C} 2$; however, at much lower numbers. Additionally, comparison with background soil samples collected from the T3B6A and T3B7A soil borings indicates the microorganisms did not migrate outside the treatment zone.

Finally, bacteria isolated from three different soil cores and identified as $\mathrm{G} 4$ by the Biolog analysis were restarted in the laboratory using glucose and BSM to test for TCE degradation capabilities. From these field cultures, 1 and $5 \mathrm{ppm}$ was degraded to below detection limits ( $<5 \mathrm{ppb}$ ) within $24 \mathrm{hr}$. In a separate experiment, 80 to $98 \%$ of a $10 \mathrm{ppm}$ TCE solution was also degraded. These experiments confirm that G4 was added to the subsurface and survived the DSM process where the TCE concentrations did not have toxic effects.

\subsubsection{Evaluation of Cost for DSM Using Bioaugmentation}

The estimated cost for DSM with bioaugmentation is based on operational cost estimates provided by $\mathrm{Geo}-\mathrm{Con}$. Geo-Con estimated equipment and crew costs at $\$ 43 / \mathrm{yd}^{3}$ assuming $30,000 \mathrm{yd}^{3}$ of soil and a treatment depth of $30 \mathrm{ft}$. Using a material ( $\mathrm{G} 4$ bacteria) cost of $\$ 10 / \mathrm{yd}^{3}$ (6.5 gal bacteria/yd $\mathrm{d}^{3}$ of soil), and a multiplier of 1.45 
to cover overhead, safety, quality control, supervision, and profit the overall estimated cost for DSM/bioaugmentation is approximately $\$ 77 / \mathrm{yd}^{3}$.

\subsection{DSM/KMnO 4 Demonstration Results}

\subsection{1 $\mathrm{KMnO}_{4}$ Background Information}

A chemical oxidation treatability study was completed in November 1995 to determine whether TCE and DCE could be degraded in contaminated soil from the KCP. Results of that study suggested that TCE removals greater than $90 \mathrm{wt} \%$ could be achieved using $\mathrm{KMnO}_{4}$ solutions of at least $4 \mathrm{wt} \%$, with oxidant loadings greater than $16 \mathrm{~g} \mathrm{KMnO}_{4} / \mathrm{kg}$ soil. During the demonstration, up to $69 \% \mathrm{TCE}$ removal in saturated soil and $83 \%$ TCE removal in unsaturated soil were achieved using a much lower average loading ( $6 \mathrm{~g} \mathrm{KMnO}_{4} / \mathrm{kg}$ soil). A lower oxidant loading was chosen for the field due to the limitation of the volume of oxidant which could be added to the low permeable soils. Thus, the $60 \%$ reduction in the oxidant loading used in the field still resulted in acceptable TCE reductions.

The $\mathrm{KMnO}_{4}$ used for the field scale demonstration was supplied by Carus Chemical Company (Peru, Illinois) in free flowing grade (granular form) packaged in $3000 \mathrm{lb}$ containers. Representatives from the manufacturer were on site to aid in the mixing of the $\mathrm{KMnO}_{4}$ slurry which was accomplished by mixing $3000 \mathrm{lb}$ of the granular $\mathrm{KMnO}_{4}$ with 4000 gal of water in a colloidal mixer. Samples of each batch of $\mathrm{KMnO}_{4}$ were collected for determination of concentration.

\subsection{2 $\mathrm{KMnO}_{4}$ Operational Information}

The DSM/KMnO ${ }_{4}$ demonstration was performed in the $\mathrm{T} 4$ and $\mathrm{T} 5$ cells illustrated in Fig. 4.3. The demonstration began with the treatment of T5 columns to a depth of $25 \mathrm{ft}$, followed by the treatment of the T4 columns to a depth of $47 \mathrm{ft}$.

$\mathrm{DSM} / \mathrm{KMnO}_{4}$ in the $\mathrm{T} 5$ cell was conducted July 12 and 13 in three overlapping test columns (T5C1, T5C2, and T5C3) with 8-ft diameters and 25-ft depths. Column $\mathrm{T} 5 \mathrm{C} 3$ was treated first and was followed by column T5C1, and finally column T5C2.

Following are chronological summaries of mixing operations for each column in the T5 cell. 

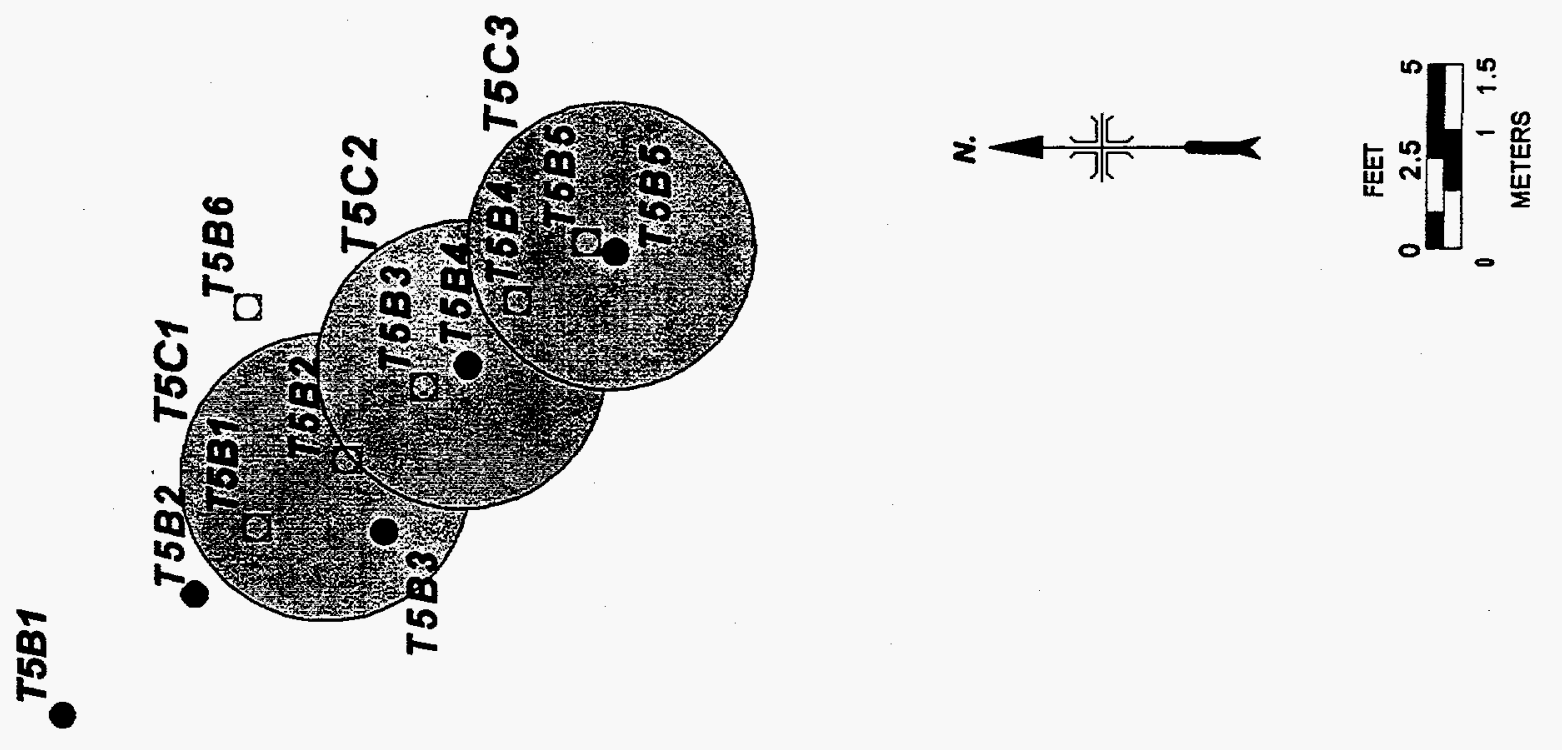

롱
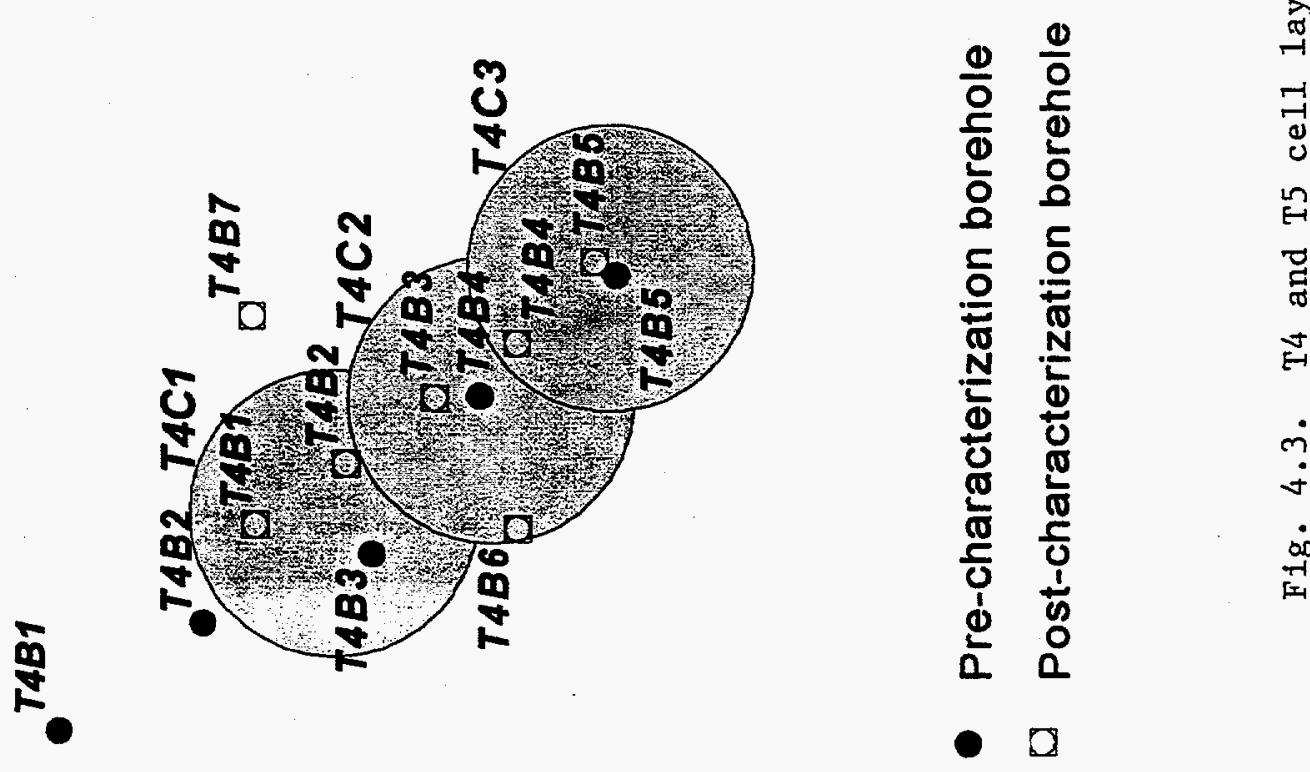


\section{T5C3 Column}

Elapsed time

0 to $21 \mathrm{~min}$

21 to $37 \mathrm{~min}$

37 to $53 \mathrm{~min}$

53 to $60 \mathrm{~min}$ 60 to $67 \mathrm{~min}$ 67 to $80 \mathrm{~min}$ 80 to $85 \mathrm{~min}$

\section{Process description}

An 8-ft diameter hole drilled with air (700 to $1000 \mathrm{cfm}$ ) to a depth of $25 \mathrm{ft}$, off gas tubing remains collapsed for the duration of the mix.

$1440 \mathrm{gal} \mathrm{KMnO}_{4}$ added between $24 \mathrm{ft}$ and surface (60 gal/ft).

$1263 \mathrm{gal} \mathrm{KMnO}_{4}$ added between surface and $24 \mathrm{ft}$ (40 gal/ft).

Mix column with no air or fluid from $24 \mathrm{ft}$ to surface. Drill from surface to $10 \mathrm{ft}$ with air $(800$ to $1000 \mathrm{cfm})$. $1000 \mathrm{gal} \mathrm{KMnO}_{4}$ added between $10 \mathrm{ft}$ and $24 \mathrm{ft}$.

Rotate out from $24 \mathrm{ft}$ to surface with no air or fluid, end mix.

Following the mixing of the $\mathrm{T} 5 \mathrm{C} 3$ column, the mixing apparatus was moved to the $\mathrm{T} 5 \mathrm{Cl}$ column located at the north end of the T5 cell. Off gas tubing is repaired with tape.

\section{T5C1 Column}

Elapsed time

0 to $14 \mathrm{~min}$

14 to $19 \mathrm{~min}$ 19 to $36 \mathrm{~min}$ 36 to $44 \mathrm{~min}$ 44 to $55 \mathrm{~min}$ 55 to $62 \mathrm{~min}$ 62 to $75 \mathrm{~min}$ 75 to $91 \mathrm{~min}$ 91 to $97 \mathrm{~min}$ 97 to $99 \mathrm{~min}$ 99 to $112 \mathrm{~min}$ 112 to $118 \mathrm{~min}$ 118 to $121 \mathrm{~min}$

\section{Process description}

An 8-ft diameter hole drilled with air (700 to $1000 \mathrm{cfm})$ to a depth of $10 \mathrm{ft}$, off gas tubing is collapsed again in spite of repair efforts.

Rotate to surface for shroud seal repair.

Drill from sufface to $25 \mathrm{ft}$ with air (700 to $1000 \mathrm{cfm})$.

560 gal $\mathrm{KMnO}_{4}$ mixed from 24 to $10 \mathrm{ft}$.

Rotate to surface for repairs.

Complete repairs.

Drill with air from surface to $10 \mathrm{ft}$.

$625 \mathrm{gal} \mathrm{KMnO}_{4}$ mixed in from $10 \mathrm{ft}$ to $25 \mathrm{ft}(40 \mathrm{gal} / \mathrm{ft})$.

$705 \mathrm{gal} \mathrm{KMnO}$ mixed in from $24 \mathrm{ft}$ to $10 \mathrm{ft}(50 \mathrm{gal} / \mathrm{ft})$

Rotate from $10 \mathrm{ft}$ to $3 \mathrm{ft}$.

Rotate from $3 \mathrm{ft}$ to $25 \mathrm{ft}$, add 64 gal $\mathrm{KMnO}_{4}$ at $25 \mathrm{ft}$.

Rotate from $25 \mathrm{ft}$ to surface with no air or fluid injection.

Lift auger above ground and clear ports with air pressure, end mix. 
Following the mixing of the $\mathrm{T} 5 \mathrm{Cl}$ column, the mixing apparatus was moved to the T5C2 column in the center of the T5 cell. Additional repair efforts to the off gas tubing include removal of slack in the line and more tape to cover torn portions.

\section{$\underline{\text { T5C2 Column }}$}

Elapsed time

0 to $4 \mathrm{~min}$

4 to $27 \mathrm{~min}$

27 to $35 \mathrm{~min}$

35 to $45 \mathrm{~min}$

45 to $50 \mathrm{~min}$

50 to $52 \mathrm{~min}$

52 to $59 \mathrm{~min}$

59 to $63 \mathrm{~min}$

\section{Process description}

Prepare for drilling.

An 8-ft diameter hole drilled with air (700 to $1000 \mathrm{cfm}$ ) to a depth of $25 \mathrm{ft}$, off gas tubing continues to collapse in any area with too much slack.

$570 \mathrm{gal} \mathrm{KMnO}_{4}$ mixed in between $24 \mathrm{ft}$ and $10 \mathrm{ft}$. $556 \mathrm{gal} \mathrm{KMnO}_{4}$ mixed in between $10 \mathrm{ft}$ and $23 \mathrm{ft}$. Rotate from $23 \mathrm{ft}$ to $8 \mathrm{ft}$ with no air or fluid injection. Rotate from $8 \mathrm{ft}$ to $23 \mathrm{ft}$ with no air or fluid injection. Rotate from $23 \mathrm{ft}$ to surface with no air or fluid injection. Lift auger above ground and clear ports with air pressure, end mix.

Following treatment of the T5 cell, the mixing apparatus is moved to the T4 cell located to the west. The drilling subcontractor agrees to provide better tubing and maintenance of the off gas tubing for the next effort at the T4 cell.

$\mathrm{DSM} / \mathrm{KMnO}_{4}$ in the $\mathrm{T} 4$ cell was conducted July 15 and 16 in three overlapping test columns (T4C1, T4C2, and T4C3) with 8-ft diameters and 47-ft depths. Column $\mathrm{T} 4 \mathrm{C} 3$ was treated first and was followed by column $\mathrm{T} 4 \mathrm{C} 1$, and finally column $\mathrm{T} 4 \mathrm{C} 2$. The amount of slack in the off gas tubing is reduced. Following are chronological summaries of mixing operations for each column in the T4 cell.

\section{T4C3 Column}

Elapsed time Process description

0 to $\overline{4} 6 \mathrm{~min}$

An 8-ft diameter hole drilled with air (700 to $1000 \mathrm{cfm}$ ) to a depth of $47 \mathrm{ft}$, off gas tubing now collapses at the inlet to the vacuum unit and Geo-Con calls the subcontractor for support which does not arrive until the $\mathrm{T} 4$ cell is completed.

46 to $77 \mathrm{~min}$ 1330 gal $\mathrm{KMnO}_{4}$ mixed in between $47 \mathrm{ft}$ and $14 \mathrm{ft}$ (40 gal/ft). 
77 to $96 \mathrm{~min}$

96 to $100 \mathrm{~min}$

100 to $125 \mathrm{~min}$

125 to $139 \mathrm{~min}$

139 to $161 \mathrm{~min}$

161 to $169 \mathrm{~min}$

169 to $180 \mathrm{~min}$
627 gal $\mathrm{KMrO}_{4}$ mixed in between $14 \mathrm{ft}$ and $47 \mathrm{ft}$ (19 gal/ft).

849 gal $\mathrm{KMnO}_{4}$ mixed in between $47 \mathrm{ft}$ and $33 \mathrm{ft}$ $(60.6 \mathrm{gal} / \mathrm{ft})$.

Rotate out from $33 \mathrm{ft}$ to surface with no injection of fluid or air.

$977 \mathrm{gal} \mathrm{KMnO}_{4}$ mixed in between $10 \mathrm{ft}$ and $47 \mathrm{ft}$

(26 gal/ft), 630 gal water added to tank to increase volume. $298 \mathrm{gal} \mathrm{KMnO}{ }_{4}$ mixed in between $47 \mathrm{ft}$ and $10 \mathrm{ft}(8 \mathrm{gal} / \mathrm{ft})$. $570 \mathrm{gal} \mathrm{KMnO}{ }_{4}$ mixed in between $10 \mathrm{ft}$ and $47 \mathrm{ft}$ (15 gal/ft).

Rotate out from $47 \mathrm{ft}$ to surface with no fluid or air injection, end of mix, (4651 gal total $\mathrm{KMnO}_{4}$ injected).

Following the mixing of the $\mathrm{T} 4 \mathrm{C} 3$ column, the mixing apparatus was moved to the $\mathrm{T} 4 \mathrm{C} 1$ column at the north end of the $\mathrm{T} 4$ cell.

\section{T4C1 Column}

\section{Elapsed time Process description}

0 to $43 \mathrm{~min}$

43 to $66 \mathrm{~min}$ 66 to $76 \mathrm{~min}$ 0 to $17 \mathrm{~min}$ 17 to $41 \mathrm{~min}$ 41 to $58 \mathrm{~min}$ 58 to $62 \mathrm{~min}$ 62 to $97 \mathrm{~min}$ 97 to $135 \mathrm{~min}$
An 8-ft diameter hole drilled with air (700 to $1000 \mathrm{~cm})$ to a depth of $47 \mathrm{ft}$, tubing collapsed at inlet to vacuum unit. $1880 \mathrm{gal} \mathrm{KMnO}_{4}$ mixed from $47 \mathrm{ft}$ to $10 \mathrm{ft}(51 \mathrm{gal} / \mathrm{ft})$. Lift auger to surface, blow out ports with air, end of day. Drill from surface to $10 \mathrm{ft}$. $782 \mathrm{gal} \mathrm{KMnO}_{4}$ mixed from $10 \mathrm{ft}$ to $47 \mathrm{ft}(21 \mathrm{gal} / \mathrm{ft})$. $816 \mathrm{gal} \mathrm{KMnO}_{4}$ mixed from $47 \mathrm{ft}$ to $10 \mathrm{ft}(22 \mathrm{gal} / \mathrm{ft})$. Rotate out to surface, $\mathrm{KMnO}_{4}$ flowing out under shroud. Drill from surface to $47 \mathrm{ft}$ with no air or fluid injection. Rotate from $47 \mathrm{ft}$ to surface with no air or fluid injection, end of mix.

Following the mixing of the $\mathrm{T} 4 \mathrm{C} 1 \mathrm{column}$, the mixing apparatus was moved to the $\mathrm{T} 4 \mathrm{C} \overline{2}$ column in the center of the $\mathrm{T} 4 \mathrm{cell}$.

\section{T4C2 Column}

Elapsed time

\section{Process description}

0 to $44 \mathrm{~min}$

An 8-ft diameter hole drilled with air (700 to $1000 \mathrm{cfm})$ to a depth of $47 \mathrm{ft}$, tubing collapsed at inlet to vacuum unit. 
44 to $58 \mathrm{~min}$

58 to $68 \mathrm{~min}$

68 to $71 \mathrm{~min}$

71 to $88 \mathrm{~min}$

88 to $100 \mathrm{~min}$

100 to $103 \mathrm{~min}$

103 to $112 \mathrm{~min}$

112 to $128 \mathrm{~min}$

128 to $135 \mathrm{~min}$
$1206 \mathrm{gal} \mathrm{KMnO}_{4}$ mixed in between $47 \mathrm{ft}$ and $10 \mathrm{ft}$ (32.6 gal/ft).

Rotate out from $10 \mathrm{ft}$ to $4 \mathrm{ft}, 1200$ gal water added to $\mathrm{KMnO}_{4}$ mixing tank.

Rotate from $4 \mathrm{ft}$ to $10 \mathrm{ft}$.

$1162 \mathrm{gal} \mathrm{KMnO}_{4}$ mixed in between $10 \mathrm{ft}$ and $47 \mathrm{ft}$ (31 gal/ft).

$300 \mathrm{gal} \mathrm{KMnO}_{4}$ mixed in between $47 \mathrm{ft}$ and $10 \mathrm{ft}(8 \mathrm{gal} / \mathrm{ft})$.

Rotate out to $7 \mathrm{ft}, 500$ gal $\mathrm{H}_{2} \mathrm{O}$ added to $\mathrm{KMnO}_{4}$ mixing tank.

420 gal $\mathrm{KMnO}_{4}$ mixed in between $7 \mathrm{ft}$ and $47 \mathrm{ft}(10.5$ $\mathrm{gal} / \mathrm{ft}$ ).

Rotate out from $47 \mathrm{ft}$ to surface with no air or fluid injection.

Clean out ports with air pressure, end of mix (3088 gal total $\mathrm{KMnO}_{4}$ added).

Table 4.4 lists the operational data from the chemical oxidation treatment cells.

Table 4.4. $\mathrm{KMnO}_{4}$ operational data

\begin{tabular}{|c|c|c|c|c|c|}
\hline $\begin{array}{l}\text { Treatment } \\
\text { column }\end{array}$ & Mix date & $\begin{array}{c}\mathrm{KMnO}_{4} \\
\text { injected, L } \\
\text { (gal) }\end{array}$ & $\begin{array}{l}\text { No. of } \\
\text { passes }\end{array}$ & $\begin{array}{l}\mathrm{KMnO}_{4} \\
\text { conc. } \\
\mathrm{wt}^{\circ}{ }^{\mathrm{a}}\end{array}$ & $\begin{array}{c}\text { Loading rate, } \\
\mathrm{g} \mathrm{KMnO}_{4} / \mathbf{k g} \\
\text { soil }\end{array}$ \\
\hline $\mathrm{T} 5 \mathrm{Cl}$ & $7 / 13 / 96$ & $\begin{array}{c}7380 \\
(1950 \mathrm{gal})\end{array}$ & 3 & 3.7 & 4.1 \\
\hline $\mathrm{T} 5 \mathrm{C} 2$ & $7 / 13 / 96$ & $\begin{array}{c}4260 \\
(1125 \mathrm{gal})\end{array}$ & 4 & 4.2 & 6.9 \\
\hline T5C3 & $7 / 12 / 96$ & $\begin{array}{c}14,000 \\
(3700 \mathrm{gal})\end{array}$ & 5 & 4.7 & 10.0 \\
\hline $\mathrm{T} 4 \mathrm{Cl}$ & $\begin{array}{l}7 / 15 \text { to } \\
7 / 16 / 96\end{array}$ & $\begin{array}{c}14,570 \\
(3850 \text { gal })\end{array}$ & 3 & 3.1 & 3.6 \\
\hline $\mathrm{T} 4 \mathrm{C} 2$ & $7 / 16 / 96$ & $\begin{array}{c}11,689 \\
(3088 \mathrm{gal})\end{array}$ & 1 & $\begin{array}{r}3.4 \\
\text { (assumed) }\end{array}$ & 6.1 \\
\hline $\mathrm{T} 4 \mathrm{C} 3$ & $7 / 15 / 96$ & $\begin{array}{c}15,140 \\
(4000 \mathrm{gal})\end{array}$ & 4 & 4.9 & 6.0 \\
\hline
\end{tabular}

${ }^{a}$ Measured using spectrophotometry, unless otherwise noted. 
As previously discussed, the most significant problems associated with the off tubing collapses are the lack of data needed to calculate air volumes and contaminant mass in the off gas stream.

The calculations used to determine the $\mathrm{KMnO}_{4}$ loading rates are presented in Appendix G. During the chemical oxidation demonstration, 25,640 L (6,775 gal) of $\mathrm{KMnO}_{4}$ was applied to the three soil columns in the T5 cell (Fig. 4.3). Assuming a porosity of $30 \%$, a particle density of $2.65 \mathrm{~g} / \mathrm{cm}^{3}$, the respective $\mathrm{KMnO}_{4}$ weight concentrations presented in Table 4.4, and the assumption that the $\mathrm{C} 2$ column (center) overlapped the adjacent columns by $60 \%$ (Fig. 4.3 ), this reagent volume results in a average field loading rate of $7.0 \mathrm{~g} \mathrm{KMnO}_{4} / \mathrm{kg}$ soil for the $\mathrm{T} 5$ cell. However, it is estimated that up to $30 \%$ of the $\mathrm{KMnO}_{4}$ added to the shallow test cells ponded on the surface of the treatment zone. The ponding resulted from the low-permeable soil's inability to adsorb the volume of reagent added. The excess reagent then followed paths of least resistance (up along the kelly bar) to the ground surface.

Because an estimated $30 \%$ of the oxidant returned to the surface, the actual loading rate may be as low as $4.9 \mathrm{~g} \mathrm{KMnO}_{4} / \mathrm{kg}$ soil in the $\mathrm{T} 5$ cell. To avoid excessive reagent ponding, the deep test columns (T4 cell) were mixed and injected with only 41,399 $\mathrm{L}(10,938 \mathrm{gal})$ of $\mathrm{KMnO}_{4}$ to yield an average in-situ oxidant loading rate of $5.2 \mathrm{~g}$ $\mathrm{KMnO}_{4} / \mathrm{kg}$ soil. Thus, significant volumes of oxidant were not observed on the ground surface following treatment of the deep test cells.

The various analyses performed on the post-treatment soil samples from the oxidation cells are presented in Table 4.5. The procedures are either referenced or included in the results and discussion section. VOC and $\mathrm{KMnO}_{4}$ analyses in the post-treatment samples were conducted on site in a mobile laboratory while the remaining analyses were performed at ORNL, Oak Ridge, Tenn.

The parameters in Table 4.5 were used to provide evidence of soil mixing efficiency and the effectiveness of the oxidation treatment. For example, increases in soil $\mathrm{pH}$, moisture content, and manganese (Mn) concentration are indicative of soils which had interacted with the $\mathrm{KMnO}_{4}$ treatment reagent. It was also expected that the overall organic content of soils treated with $\mathrm{KMnO}_{4}$ would be reduced as this reagent is a non-specific oxidant that will consume both contaminants and natural soil organic matter (SOM). Microbial sampling and analyses were conducted to determine whether oxidation with $\mathrm{KMnO}_{4}$ destroys or alters the bacterial population in the soil. Any intrinsic microbes present after initial treatment with $\mathrm{KMnO}_{4}$ may be effective in further degrading any residual contamination present. Due to the close proximity of the T5 and T4 cells, post-treatment sampling of either test cell could not safely be conducted until both cells had been mixed. This resulted in a minimum delay of three days between mixing and post-treatment sampling. Post-treatment sampling information for each soil boring in the $\mathrm{T} 5$ and $\mathrm{T} 4$ cells is presented in Table 4.6. 
Table 4.5. DSM post-treatment analyses and procedures

\begin{tabular}{||l|l||}
\hline \multicolumn{1}{|c|}{ Analysis/Parameter } & \multicolumn{1}{c|}{ Method/Procedure } \\
\hline Soil pH (ASTM D4972) & $1: 1 \mathrm{wt} /$ wt slurry (deionized water) \\
\hline VOC concentration & GC (hexane extraction) \\
\hline $\mathrm{KMnO}_{4}$ concentration & $\begin{array}{l}\text { Spectrophotometry }(0.01 \mathrm{M} \mathrm{NaCl} \\
\text { extraction) }\end{array}$ \\
\hline Moisture content (ASTM D4959) & $\begin{array}{l}\text { Gravimetric Analysis (100 C } \\
\text { Drying) }\end{array}$ \\
\hline Manganese (Mn) content (Carter 1993) & $\begin{array}{l}\text { Exchangeable Cations } \text { (NH }_{4}^{-} \\
\text {Acetate extraction) }\end{array}$ \\
\hline Total Carbon (TC) content & $\begin{array}{l}\text { Dorhmann DC 190 Carbon } \\
\text { Analyzer }\end{array}$ \\
\hline Total Organic Carbon (TOC) content & $\begin{array}{l}\text { Dorhmann DC 190 Carbon } \\
\text { Analyzer (Acid prepped) }\end{array}$ \\
\hline Microbial analyses & $\begin{array}{l}\text { Aerobic and Anaerobic Plating and } \\
\text { Counting }\end{array}$ \\
\hline
\end{tabular}

ASTM: American Society for Testing and Materials 
Table 4.6. $\mathrm{KMnO}_{4}$ sampling information

\begin{tabular}{|c|c|c|c|}
\hline Soil boring & $\begin{array}{c}\text { Associated } \\
\text { column }\end{array}$ & Sampling date & Days after mixing \\
\hline BKG-BH2 & NA & $7 / 16 / 96$ & NA \\
\hline T5B1 & T5C1 & $7 / 17 / 96$ & 4.4 \\
\hline T5B2 & T5C1 & $7 / 17 / 96$ & 4.5 \\
\hline T5B3 & T5C2 & $7 / 17 / 96$ & 4.6 \\
\hline T5B4 & T5C2 & $7 / 17 / 96$ & 4.7 \\
\hline T5B5 & T5C3 & $7 / 18 / 96$ & 6.4 \\
\hline T5B6 & NA & $7 / 23 / 96$ & $\sim 10$ \\
\hline T4B1 & T4C1 & $7 / 18 / 96$ & 3.6 \\
\hline T4B2 & T4C1 & $7 / 18 / 96$ & 3.7 \\
\hline T4B3 & T4C2 & $7 / 19 / 96$ & 3.4 \\
\hline T4B4 & T4C2 & $7 / 19 / 96$ & 3.4 \\
\hline T4B5 & T4C3 & $7 / 19 / 96$ & 3.6 \\
\hline T4B6 & NA & $7 / 20 / 96$ & $\sim 4$ \\
\hline
\end{tabular}

$\mathrm{NA}=$ not applicable

The following sections present the results of the various analyses performed on the post-treatment soil samples collected from the $\mathrm{KMnO}_{4}$ treatment cells $\mathrm{T} 4$ and $\mathrm{T} 5$.

\subsubsection{Post-Treatment VOC Results from $\mathrm{KMnO}_{4}$ Cells}

As previously discussed, the post-treatment boring locations were not intended to replicate the pre-treatment borings clue to the redistributing effects of the mixing action. The post-treatment samples w/ere, however, collected in similar fashion and locations as the pre-treatment samples. Furthermore, the inherent heterogeneity in the pre-treatment soil sample data combined with the redistribution of soil characteristics in the post-treatment soil sample data resulting from the mixing effects, required that the data sets be averaged to provide useful interpretation of the treatment effectiveness. The pre- and post-treatment VOC results for T5 and T4 cells are presented in Appendices B and E respectively. It should be noted that several pre-treatment samples from the T4 and T5 cells with detectable levels of cis-1,2-DCE 
are presented in Appendix B. No cis-1,2-DCE, however, was detected in any of the post-treatment samples from the T4 and T5 cells. Thus, the VOC mass removal efficiency discussion is limited to TCE because there is insufficient data regarding cis1,2-DCE to make any significant conclusion other than it was completely removed by the $\mathrm{DSM} / \mathrm{KMnO}_{4}$ treatment.

The average TCE concentration for each soil boring was calculated by summing the depth-specific TCE values provided in Appendices B and E and dividing by the number of depth intervals in each boring. The TCE results from the pre- and posttreatment soil borings were treated in the same manner as previously discussed in the bioaugmentation section. Using the data in Appendices B and E, pre- and posttreatment average TCE concentrations in soil for the T5 and T4 cells have been averaged and are presented in Tables 4.7 and 4.8 , respectively. The soil boring locations for the T5 and T4 cells are presented in Fig. 4.3.

\section{Table 4.7. Pre- and post-treatment average TCE concentrations in $\mathrm{T} 5$ Cell borings}

\begin{tabular}{|l|l|l|l|l|l|l|l|l|l|l|l|l||}
\hline \multicolumn{3}{|c|}{ T5C1 Column } & \multicolumn{4}{c|}{ T5C2 Column } & \multicolumn{3}{c|}{ T5C3 Column } \\
\hline $\begin{array}{l}\text { Pre- } \\
\text { treat } \\
\text { boring } \\
\text { No. }\end{array}$ & $\begin{array}{l}\text { Aver- } \\
\text { age } \\
\text { TCE, } \\
\mathrm{mg} / \mathrm{kg}\end{array}$ & $\begin{array}{l}\text { Post- } \\
\text { treat } \\
\text { boring } \\
\text { No. }\end{array}$ & $\begin{array}{l}\text { Aver- } \\
\text { age } \\
\mathrm{TCE}, \\
\mathrm{mg} / \mathrm{kg}\end{array}$ & $\begin{array}{l}\text { Pre- } \\
\text { treat } \\
\text { boring } \\
\text { No. }\end{array}$ & $\begin{array}{l}\text { Aver- } \\
\text { age } \\
\mathrm{TCE}, \\
\mathrm{mg} / \mathrm{kg}\end{array}$ & $\begin{array}{l}\text { Post- } \\
\text { treat } \\
\text { boring } \\
\text { No. }\end{array}$ & $\begin{array}{l}\text { Aver- } \\
\text { age } \\
\mathrm{TCE}, \\
\mathrm{mg} / \mathrm{kg}\end{array}$ & $\begin{array}{l}\text { Pre- } \\
\text { treat } \\
\text { boring } \\
\text { No. }\end{array}$ & $\begin{array}{l}\text { Aver- } \\
\text { age } \\
\mathrm{TCE}, \\
\mathrm{mg} / \mathrm{kg}\end{array}$ & $\begin{array}{l}\text { Post- } \\
\text { treat } \\
\text { boring } \\
\text { No. }\end{array}$ & $\begin{array}{l}\text { Aver- } \\
\text { age } \\
\text { TCE, } \\
\mathrm{mg} / \mathrm{kg}\end{array}$ \\
\hline T5B3 & 118.0 & T5B2 & 11.4 & T5B4 & 35.0 & T5B2 & 11.4 & T5B5 & 0.05 & T5B5 & 0.9 \\
\hline & & T5B3 & 8.4 & & & T5B3 & 8.4 & & & & \\
\hline
\end{tabular}

Table 4.8. Pre- and post-treatment average TCE concentrations in $\mathrm{T} 4$ Cell borings

\begin{tabular}{||l|l|l|l|l|l|l|l|l|l|l|l||}
\hline \multicolumn{3}{|c|}{ T4C1 Column } & \multicolumn{4}{c|}{ T4C2 Column } & \multicolumn{3}{c|}{ T4C3 Column } \\
\hline $\begin{array}{l}\text { Pre- - } \\
\text { treat } \\
\text { boring } \\
\text { No. }\end{array}$ & $\begin{array}{l}\text { Aver- } \\
\text { age } \\
\text { TCE, } \\
\mathrm{mg} / \mathrm{kg}\end{array}$ & $\begin{array}{l}\text { Post- } \\
\text { treat } \\
\text { boring } \\
\text { No. }\end{array}$ & $\begin{array}{l}\text { Aver- } \\
\text { age } \\
\mathrm{TCE}, \\
\mathrm{mg} / \mathrm{kg}\end{array}$ & $\begin{array}{l}\text { Pre- } \\
\text { treat } \\
\text { boring } \\
\text { No. }\end{array}$ & $\begin{array}{l}\text { Aver- } \\
\text { age } \\
\mathrm{TCE}, \\
\mathrm{mg} / \mathrm{kg}\end{array}$ & $\begin{array}{l}\text { Post- } \\
\text { teat } \\
\text { boring } \\
\text { No. }\end{array}$ & $\begin{array}{l}\text { Aver- } \\
\text { age } \\
\mathrm{TCE}, \\
\mathrm{mg} / \mathrm{kg}\end{array}$ & $\begin{array}{l}\text { Pre- } \\
\text { treat } \\
\text { boring } \\
\text { No. }\end{array}$ & $\begin{array}{l}\text { Aver- } \\
\text { age } \\
\mathrm{TCE}, \\
\mathrm{mg} / \mathrm{kg}\end{array}$ & $\begin{array}{l}\text { Post- } \\
\text { treat } \\
\text { boring } \\
\text { No. }\end{array}$ & $\begin{array}{l}\text { Aver- } \\
\text { age } \\
\mathrm{TCE}, \\
\mathrm{mg} / \mathrm{kg}\end{array}$ \\
\hline T4B3 & 336.7 & T4B1 & 210.7 & $\mathrm{T4B} 4$ & 202.2 & $\mathrm{T4B} 2$ & 42.6 & T4B5 & 161.2 & T4B4 & 62.1 \\
\hline & & T4B2 & 42.6 & & & T4B3 & 58.5 & & & T4B5 & 11.8 \\
\hline
\end{tabular}

The average TCE concentrations for each pre-treatment boring in each of the T5 columns shown in Table 4.7 were then averaged to arrive at an average pre-treatment 
TCE concentration for each column. The respective average pre-treatment TCE concentrations for the $\mathrm{C} 1, \mathrm{C} 2$, and $\mathrm{C} 3$ columns are 118,35 , and $0.05 \mathrm{mg} / \mathrm{kg}$, which yield an average pre-treatment TCE concentration of $51 \mathrm{mg} / \mathrm{kg}$ for the T5 cell. The mass of soil for the T5 cell was calculated using three $25-\mathrm{ft}$ deep columns with 8-ft diameters, a $60 \%$ overlap for the center column, a particle density of $2.65 \mathrm{~g} / \mathrm{cm}^{3}$ and an estimated porosity of $30 \%$. The resulting mass of soil in the T5 cell is $158,548 \mathrm{~kg}$ which when multiplied by the average TCE concentration $(51 \mathrm{mg} / \mathrm{kg}$ ) for the T5 cell yields a total pre-treatment TCE mass of $8.1 \mathrm{~kg}$.

The average TCE concentrations from each of the post-treatment soil borings in the T5 columns shown in Table 4.7 were treated in the same fashion and yield respective average post-treatment TCE concentrations for the $\mathrm{C} 1, \mathrm{C} 2$, and $\mathrm{C} 3$ columns of 9.9, 15.7 , and $0.9 \mathrm{mg} / \mathrm{kg}$ which yield an average post-treatment TCE concentration of 8.8 $\mathrm{mg} / \mathrm{kg}$ in the T5 cell. The calculated total mass of TCE remaining after mixing in the T5 cell $(8.8 \mathrm{mg} / \mathrm{kg}$ TCE $\times 158,548 \mathrm{~kg}$ soil) is $1.4 \mathrm{~kg}$. Comparing the pre- and posttreatment TCE mass values of 8.1 and 1.4 indicates an overall removal of $83 \%$ or 6.7 $\mathrm{kg}$ of TCE from the unsaturated soil in the T5 cell.

The data presented in Table 4.8 represent the pre- and post-treatment TCE concentrations from soil borings in the three columns of the T4 cell. These data were treated in the same manner described above and are discussed below. The average pre-treatment TCE concentration for the T4 cell using the average $\mathrm{C} 1, \mathrm{C} 2$, and $\mathrm{C} 3$ column average TCE values $(337,202$, and $161 \mathrm{mg} / \mathrm{kg}$ derived from Table 4.8$)$ is 233 $\mathrm{mg} / \mathrm{kg}$ of TCE. The mass of soil in the T4 cell was calculated to be $298,161 \mathrm{~kg}$ using the same previously discussed parameters with exception of the 47-ft depth variable. The resulting mass of pre-treatment TCE in the T4 cell was then calculated to be 69.5 $\mathrm{kg}$.

The average post-treatment TCE concentration for the $\mathrm{T} 4$ cell results from the averaging of the $\mathrm{C} 1, \mathrm{C} 2$, and $\mathrm{C} 3$ column average TCE values $(127,54$, and $37 \mathrm{mg} / \mathrm{kg}$ derived from Table 4.8 ) and is $72.7 \mathrm{mg} / \mathrm{kg}$ of TCE. The mass of post-treatment TCE in the T4 cell was calculated $(72.7 \mathrm{mg} / \mathrm{kg}$ TCE $\times 298,161 \mathrm{~kg}$ soil) to be $21.7 \mathrm{~kg}$ TCE and represents a mass reduction of $69 \%$ or $47.8 \mathrm{~kg}$ of TCE from the saturated soil in the T4 cell.

The $83 \%$ and $69 \%$ reductions in TCE mass achieved by the $\mathrm{DSM} / \mathrm{KMnO}_{4}$ compare favorably with the treatment objective of $70 \%$. It is useful to note that different TCE mass reductions could be represented with the data sets. For example, the values could be calculated on a per-column basis rather than a per cell basis and show that one column (T5C3) where the post-treatment TCE exceeds the pre-treatment TCE mass. However, because of the inherent heterogeneity in soil sampling and the redistribution of soil characteristics introduced by the soil mixing process, it is difficult to draw any significant conclusion from this approach. Moreover, the bulk of the 
pre-and post-treatment data from the $\mathrm{T} 4$ and $\mathrm{T} 5$ cells suggest that treatment did in fact take place and, thus, indicate that treatment of the data on a per-cell basis is appropriate.

Post-treatment groundwater samples were to be collected after installing piezometers into the boreholes created as a result of the soil sampling event. Although piezometers were installed in boreholes T5B3 and T4B3, most of the boreholes collapsed before the wells could be installed because of the high moisture content of the treated soils. Two groundwater samples collected from the T5B3 borehole had an average TCE concentration of $3.2 \mathrm{mg} / \mathrm{L}$, representing a $40 \%$ decrease over the pre-treatment TCE concentration in groundwater for that column.

Groundwater samples from borehole T4B3 contained $4.2 \mathrm{mg} / \mathrm{L}$ of TCE which represents a $99 \%$ decrease from the $630 \mathrm{mg} / \mathrm{L}$ average TCE concentration the pretreatment boring T4B3. A thorough evaluation of whether oxidant and or contaminants migrated out the mixed area could not be made due to the limited number of samples available. However, a $\mathrm{KMnO}_{4}$ concentration of $1.1 \mathrm{wt} \%$ was detected in a groundwater sample from one of the adjacent biotreatment boreholes (T3B5) located immediately west of the T4 cell. Interestingly, this groundwater sample was the only one within the biotreatment cells in which no TCE was detected. (The average posttreatment TCE concentration in groundwater for the biotreatment cell (T3) was 37 $\mathrm{mg} / \mathrm{L}$.)

To satisfy MDNR permitting criteria, groundwater samples were collected from two existing monitoring wells (KC84-018L and KC84-018U) located approximately 100 $\mathrm{ft}$ hydraulically downgradient or north east of the $\mathrm{T} 4 \mathrm{cell}$. The samples were collected July 23 and reported $\mathrm{Mn}$ concentrations of 551 and $6810 \mu \mathrm{g} / \mathrm{L}$ in $18 \mathrm{U}$ and $18 \mathrm{~L}$ respectively. These values are comparable with historical data from these wells.

\subsubsection{Oxidation vs Vapor Stripping}

The amount of TCE stripped from the subsurface from the initial drilling and subsequent mixing of the T5 and T4 columns is difficult to quantify for the reasons previously discussed. First, a limited number of off gas samples were analyzed with the GC (see Table 3.2). Second, the presence of other organic compounds (hydrocarbons and semi-volatiles) in the off gas stream limit the value of the total VOC recorded by the FID. Third, the lack of consistent off gas temperature and volume data due to previously discussed operating conditions, make this estimation more difficult.

It is obvious that the initial drilling of the cells using 800 to $1000 \mathrm{cfm}$ of air was responsible for the volatilization of TCE and other unknown VOCs. It is also apparent 
from the DAS graphic plots presented in Appendix C, that the subsequent passes with $\mathrm{KMnO}_{4}$ triggered less volatilization. The peak total VOCs recorded with the FID range from $12,000 \mathrm{ppm}$ in $\mathrm{T} 5 \mathrm{C} 3$ to $44,000 \mathrm{ppm}$ in $\mathrm{T} 4 \mathrm{C} 1$. The peaks were all associated with the initial drilling of the columns and correspond to a depth of about $20 \mathrm{ft}$ bgs where the highest amounts of TCE were identified in the pre-treatment borings. The effects of stripping following the initial drilling with air appear to taper off considerably as the total VOCs recorded after the initial peaks are typically below $200 \mathrm{ppm}$.

\subsubsection{Other Post-Treatment Sample Results from $\mathrm{KMnO}_{4}$ Cells}

Following are summaries of post-treatment sampling results that include $\mathrm{KMnO}_{4}$ and Mn concentrations in soil, soil pH, soil moisture content, soil carbon/organic carbon content, and soil microbial analysis.

\subsubsection{Soil $\mathrm{KMnO}_{4}$ and $\mathrm{Mn}$ Concentrations}

Results from the treatability study (Appendix F) indicated nearly complete oxidant degradation within $24 \mathrm{~h}$ when contacted with KCP soils. This phenomenon is largely caused by rapid oxidant consumption by the soil's high natural SOM content. In addition, the mixed regions were not sampled until a minimum of three days after oxidant injection. The concentration of $\mathrm{KMnO}_{4}$ for each background sample and each post-treatment sample collected from the mixed regions was determined on-site immediately after sample collection. A known mass of soil was extracted with 0.01 $\mathrm{M} \mathrm{NaCl}$, filtered, and analyzed via ultra violet visible spectrophotometry $(525 \mathrm{~nm})$ for $\mathrm{KMnO}_{4}$. Although this method is quick and economical, it is limited by a rather crude detection limit of $0.1 \mathrm{mg} / \mathrm{kg}$ for $\mathrm{KMnO}_{4}$. As expected, the $\mathrm{KMnO}_{4}$ concentrations for the background soil boring (BKGBH2 in Fig. 4.1) were non detectable $(<0.1 \mathrm{mg} / \mathrm{kg})$ because the background boring should not have been affected by the demonstration activities, being located approximately $150 \mathrm{ft}$ west of the near $\mathrm{KMnO}_{4}$ treatment cell. However, the lack of any detectable $\mathrm{KMnO}_{4}$ in the shallow and deep treatment cells indicated that another indicator be used.

Because $\mathrm{KMnO}_{4}$ degrades rapidly, $\mathrm{Mn}$ was used as an alternative indicator for the distribution of the oxidant reagent. Thus, analyses for $\mathrm{Mn}$ in the background and post-treatment samples were performed. In addition to the post-treatment soil borings collected from the treatment zone, two more soil borings were drilled from an area outside of the treatment columns, approximately 1 to $3 \mathrm{ft}$ from the mixed columns (post T5B6 and post T4B6 in Fig. 4.3). Analyzing these samples for Mn would be useful in determining the extent, if any, of $\mathrm{KMnO}_{4}$ migration outside of the treatment zone. 
The Mn content of the soils was determined using a cation exchange procedure (Carter 1993), because $\mathrm{Mn}$ deposited on the soil as a result of $\mathrm{KMnO}_{4}$ addition would likely be loosely bound to the soil surfaces. The results of the $\mathrm{Mn}$ analyses are presented in Figs. 4.4 and 4.5, for the shallow and deep cells, respectively. For comparison, $\mathrm{Mn}$ data for the background soil boring (BKGBH2) located approximately $150 \mathrm{ft}$ from the treatment cells, is also provided in each of these figures. Use of $\mathrm{Mn}$ analyses, however, is unfounded by the fact that naturally occurring manganese dissolved by the highly reducing subsurface conditions can be found at ppm levels at the KCP. Nevertheless, the soil boring collected outside of the shallow cells (post T5B6 in Fig. 4.3) suggests that some Mn migration because the Mn concentrations there are higher than background but not nearly as great as those observed for the soil borings inside of the treated columns. [The average Mn soil concentration outside of the shallow cells $(119 \mathrm{mg} / \mathrm{kg})$ is approximately $32 \%$ of that found within the $T 5$ columns $(376 \mathrm{mg} / \mathrm{kg})]$.

A similar Mn distribution was also observed in and around the deeper T4 treatment cells. The average Mn concentration within the T4 region was $442 \mathrm{mg} / \mathrm{kg}$ while the amount of Mn outside of the T4 cell is approximately $106 \mathrm{mg} / \mathrm{kg}$ or $24 \%$ of that within the $\mathrm{T} 4$ cell.

\subsubsection{Soil pH}

Soil $\mathrm{pH}$ typically increases after mixing with $\mathrm{KMnO}_{4}$. The background and posttreatment soil $\mathrm{pH}$ data are presented in Figs. 4.6 and 4.7 for the T5 and T4 cells, respectively. With the exception of the post $\mathrm{T} 4 \mathrm{~B} 1$ boring with an average $\mathrm{pH}$ of 6.9 , the $\mathrm{pH}$ of each post-treatment soil boring was elevated above the average background soil $\mathrm{pH}$ of 7.0. The average soil $\mathrm{pH}$ from the five post-treatment soil borings in the T5 cell increased to 7.6, while an average $\mathrm{pH}$ of 8.0 was measured for the four posttreatment borings collected from the $\mathrm{T} 4$ cell. The $\mathrm{pH}$ of the $\mathrm{KMnO}_{4}$ used during the demonstration was not measured or recorded; however, the $\mathrm{pH}$ of a $5 \mathrm{wt} \% \mathrm{KMnO}_{4}$ solution prepared in the laboratory with distilled water was measured to be 8.04 . Thus, it appears that values obtained from the post-treatment samples are reasonable.

\subsubsection{Soil Moisture Content}

Post-treatment soil moisture contents were also determined for each soil boring location (including post-T5B6 and post-T4B6 outside of the mixed cells) as another means to evaluate oxidant migration and/or mixing homogeneity. During the course of the demonstration, a total of 67,039 liters $(17,710 \mathrm{gal})$ of solution were added to 


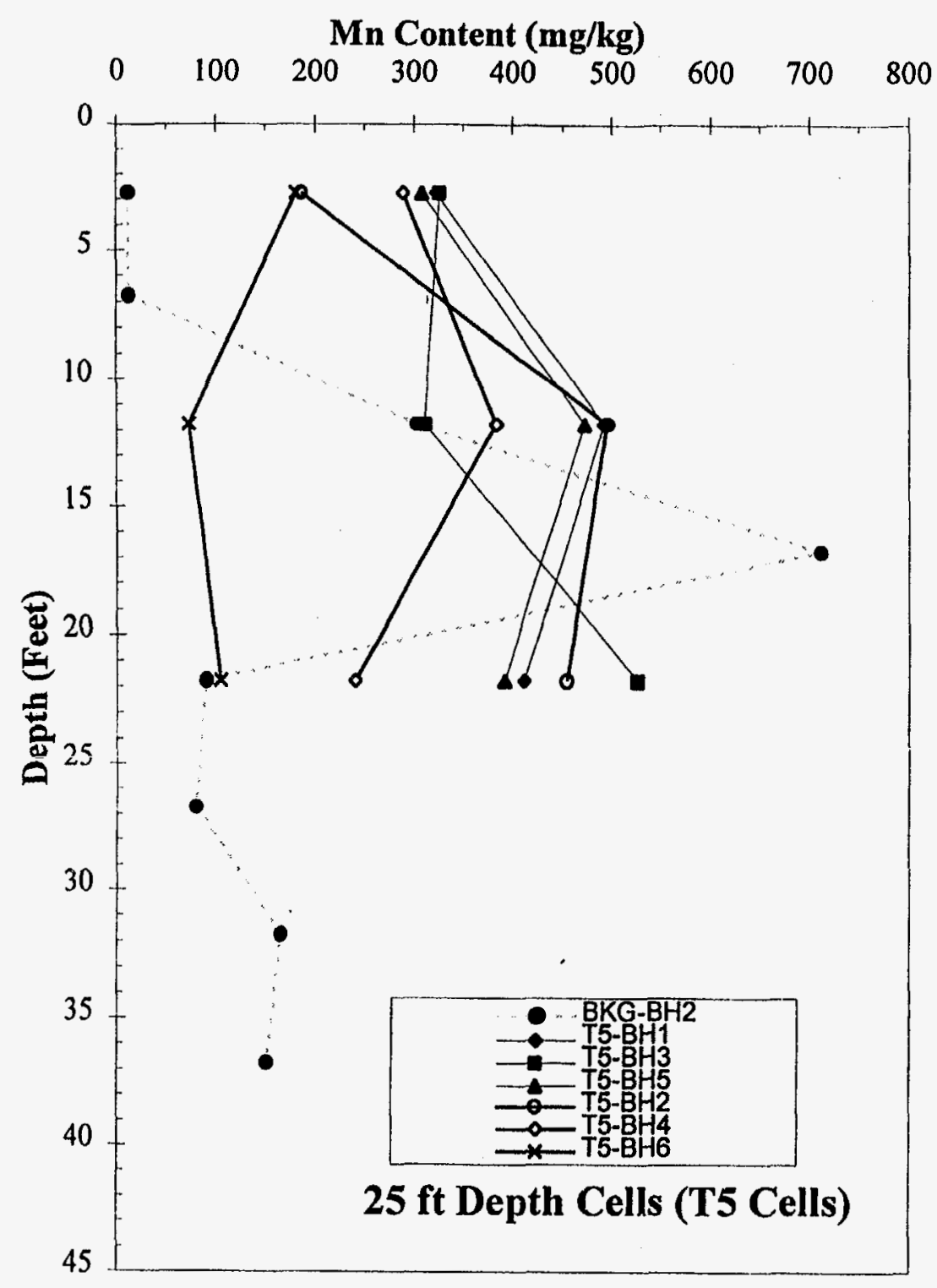

Fig. 4.4. Mn concentrations of the posttreatment T5 soil borings.

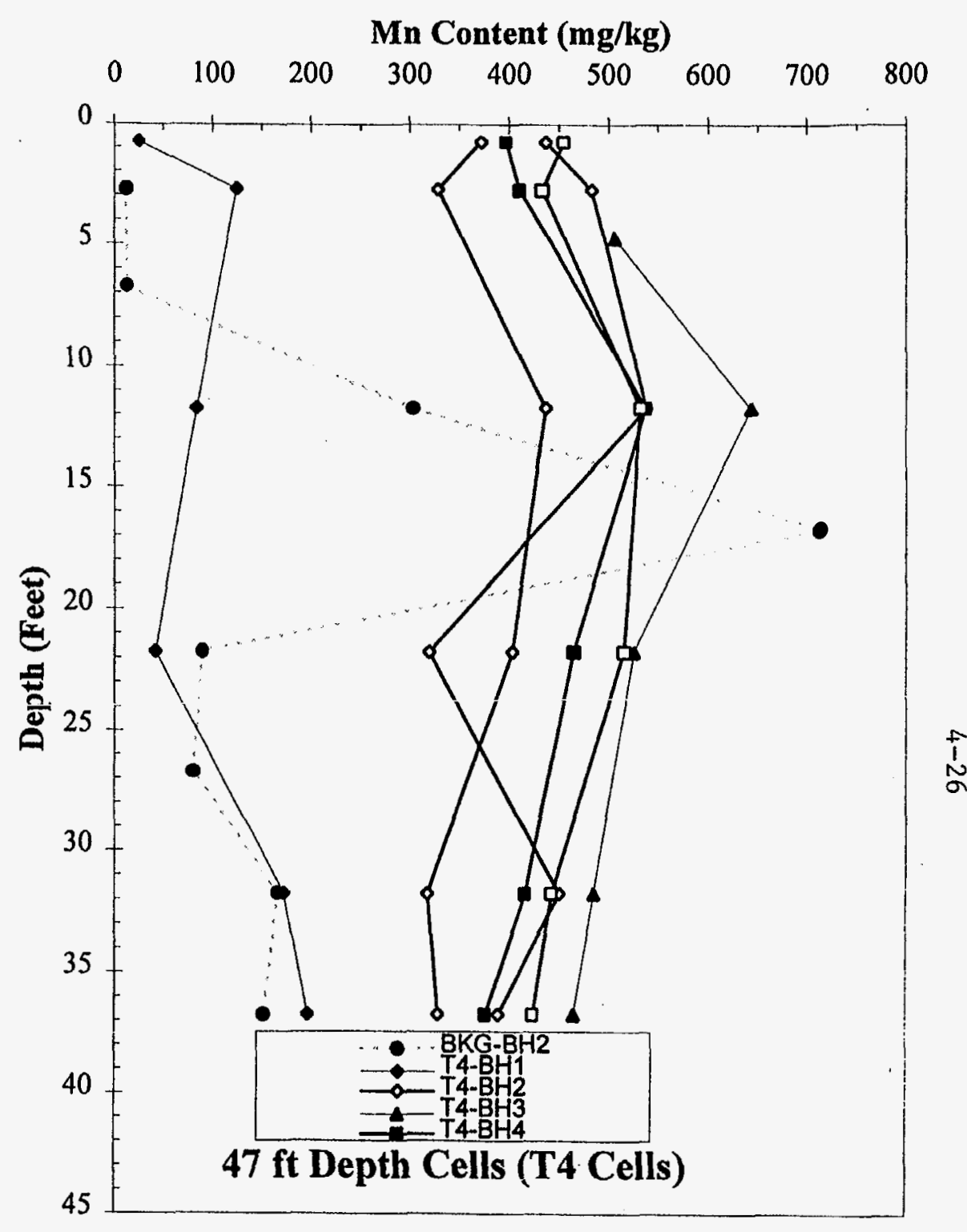

Fig. 4.5. Mn concentrations of the posttreatment T4 soil borings. 


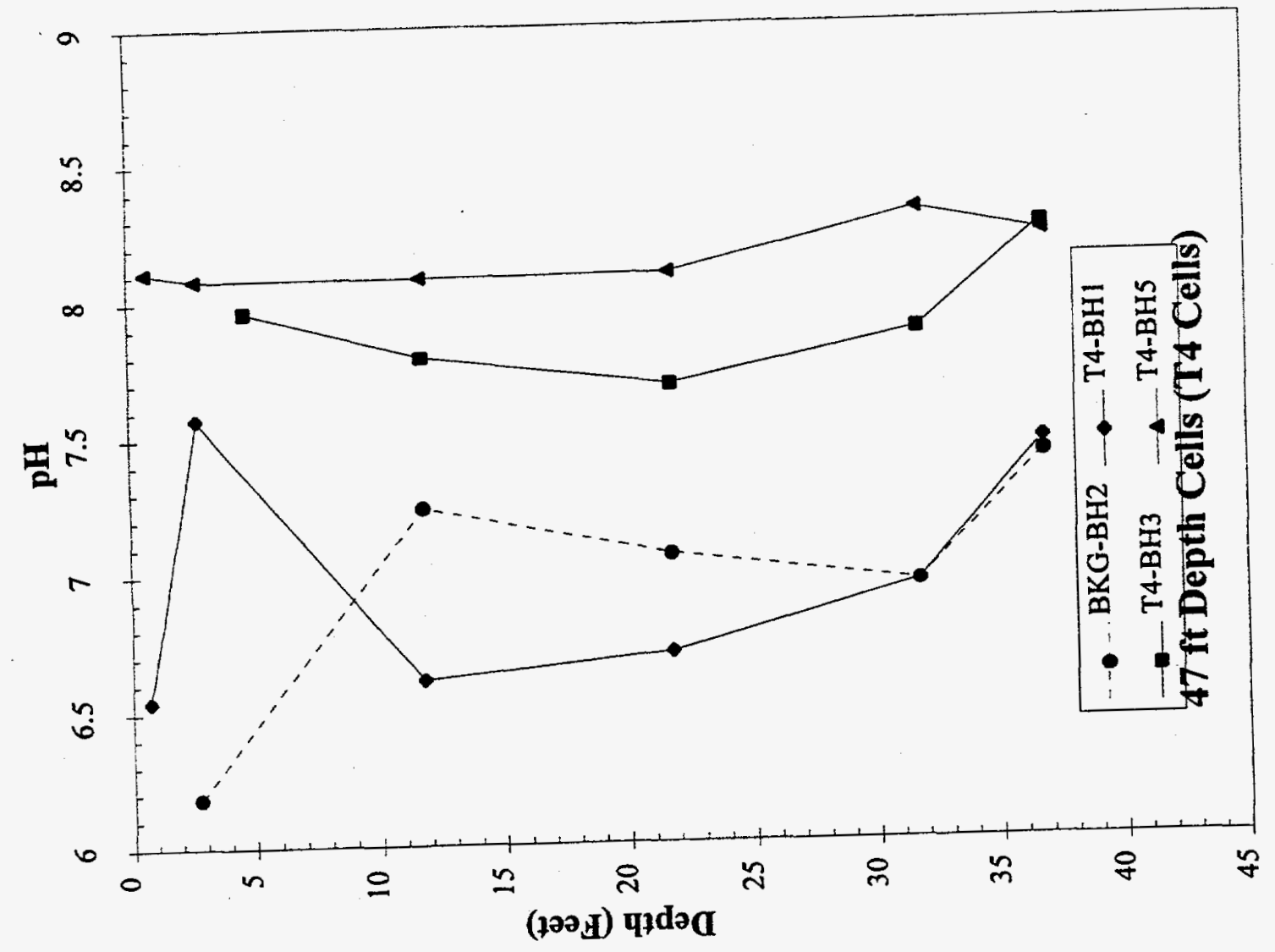

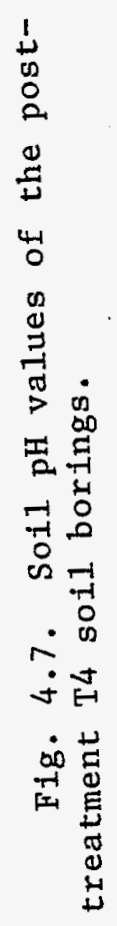

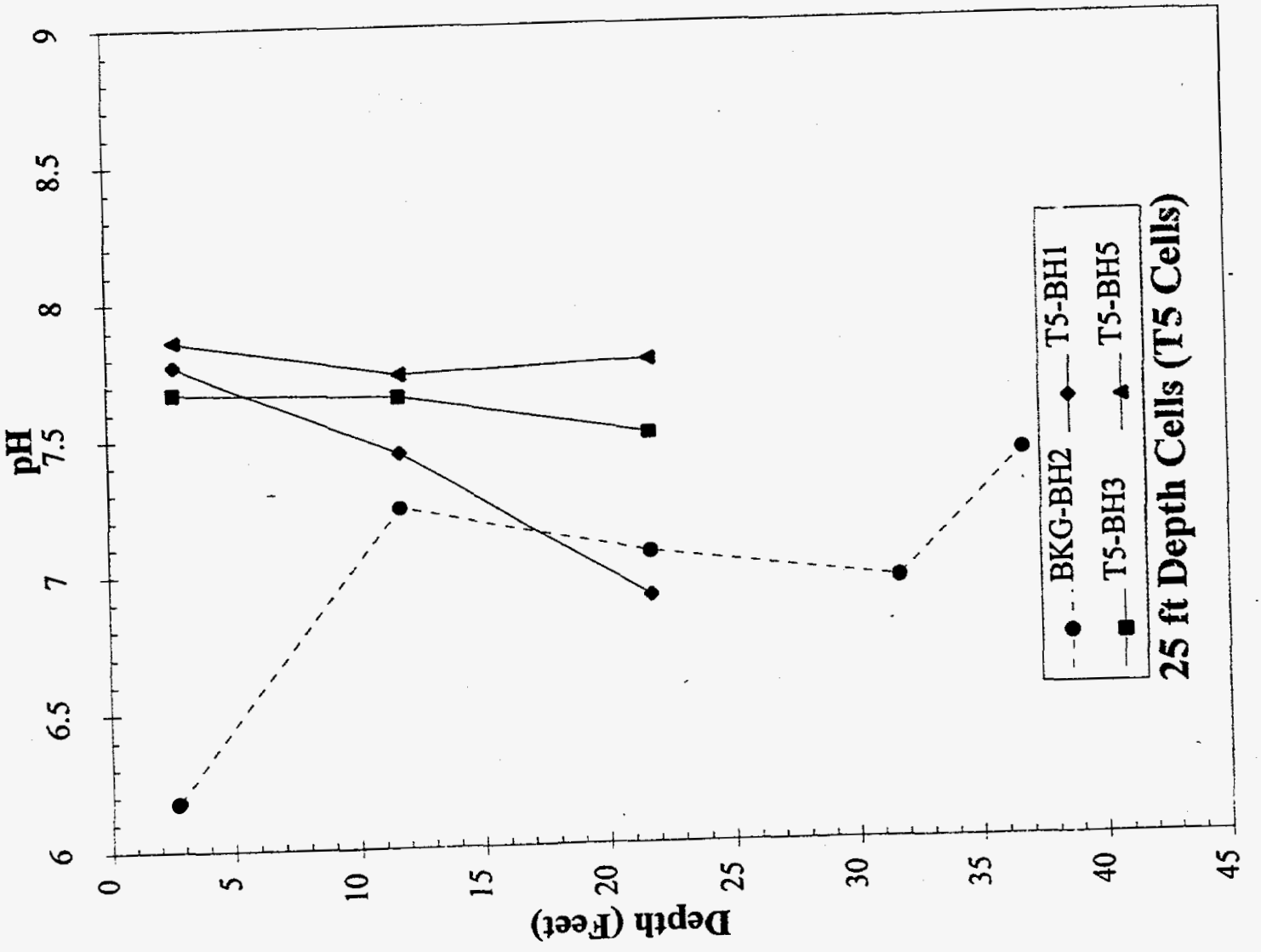

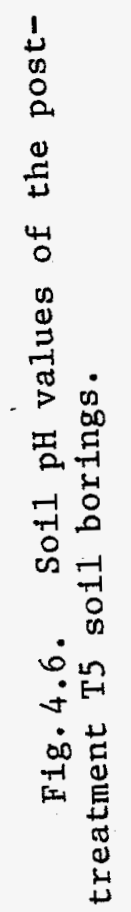


the mixed regions. The average soil moisture content of the background, untreated soil boring was found to be $28.10 \mathrm{wt} \%$. The moisture contents obtained for the posttreatment samples are presented in Figs. 4.8 and 4.9 for the shallow and deep cell, respectively. All samples from within the treatment zones yielded moisture values significantly greater than the background samples. The average increase in moisture within the T5 columns was found to be $21 \%$ greater than background. The moisture content of the T5B5 soil boring was particularly elevated ( $47 \%$ greater than background). This effect may be attributed to the significant ponding in the T5C3 column which was mixed first. In fact, notes recorded in the field for the posttreatment boring T5B5 in the 2.5 to $3 \mathrm{ft}$ depth interval stated that this sample appeared to be "a lot more wet/slurried than any other sample collected from the T5 cell."

The moisture content of the T4 cell samples increased from an average $28 \%$ to $41 \%$. These observed increases appear to be a direct result of oxidant injection, because field records indicated that no rainfall events occurred between the mixing and subsequent sampling of the $\mathrm{KMnO}_{4}$ cells. The average standard deviations computed for the soil borings was nearly constant $(=5.2 \mathrm{wt} \%)$ for both the T4 and T5 cells, suggesting homogeneous mixing (i.e., little variation in moisture with depth).

\subsubsection{Soil Carbon and Organic Carbon Content}

Because $\mathrm{KMnO}_{4}$ also reacts readily with natural SOM, the background and posttreatment samples were also subjected to TC and TOC analyses to evaluate the effect of chemical oxidation on this soil property. All TOC and TC analyses were performed using a Dorhmann ${ }^{\mathrm{TM}}$ DC 190 carbon analyzer. The TC values for selected soil borings from the shallow and deep cells are presented in Figs. 4.10 and 4.11, respectively. Similarly, the TOC values for selected soil borings from the shallow and deep cells are presented in Figs. 4.12 and 4.13, respectively. The TOC samples were pre-treated with a $1: 4 \mathrm{HCl} / \mathrm{H}_{2} 0$ solution while being heated and mixed to sparge the samples of any carbonate species. Upon examination of the results, it was found that a direct comparison of the treated samples with the background soil boring could not be made. The post-treatment TC and TOC values were higher than background, probably due to the presence of residual organic contaminants in the post treated soils. Thus, the TOC/TC ratio was computed for each sample and appears to be the best parameter for evaluating the post-treatment results. It is assumed that the extent of oxidation (of both SOM and organic contaminants) increases as the TOC/TC ratio decreases. The TOC/ TC ratios obtained for selected shallow and deep soil borings are presented in Fig. 4.14. In nearly all cases, the TOC/TC ratio at each depth interval is less than that of background. The average TOC/TC ratio for the background soil boring was calculated to be $0.88(=0.18)$, while the average value for the shallow and deep soil borings was found to be $0.59(=0.14)$ and $0.69(=$ 0.19), respectively. Comparing the TOC/TC ratio for each soil boring with the VOC 
Moisture Content (wt\%)

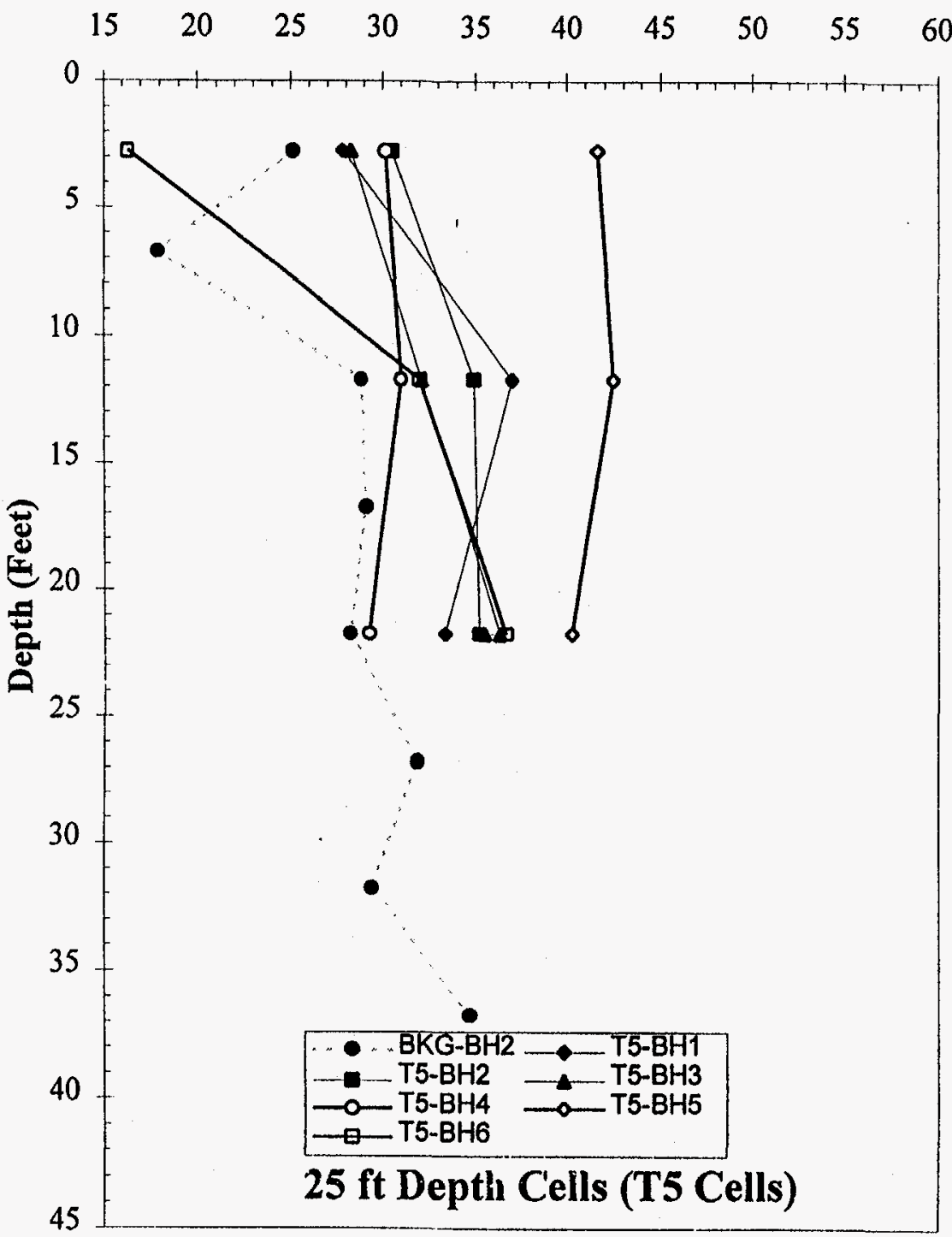

Fig.4.8. Moisture contents of the posttreatment $\mathrm{T} 5$ soll borings.

\section{Moisture Content (wt\%)}

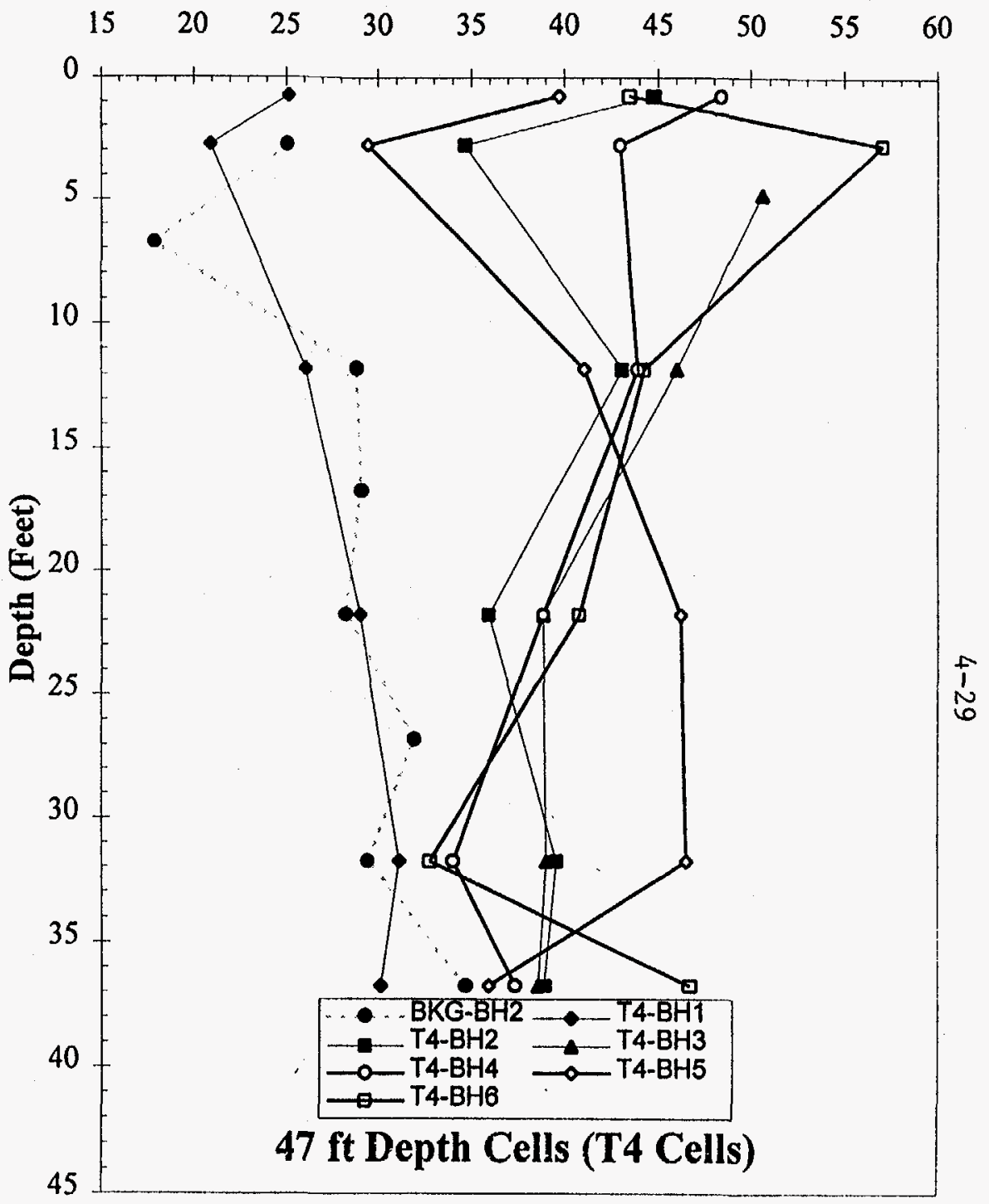

Fig.4.9. Moisture contents of the posttreatment $\mathrm{T} 4$ soil borings. 


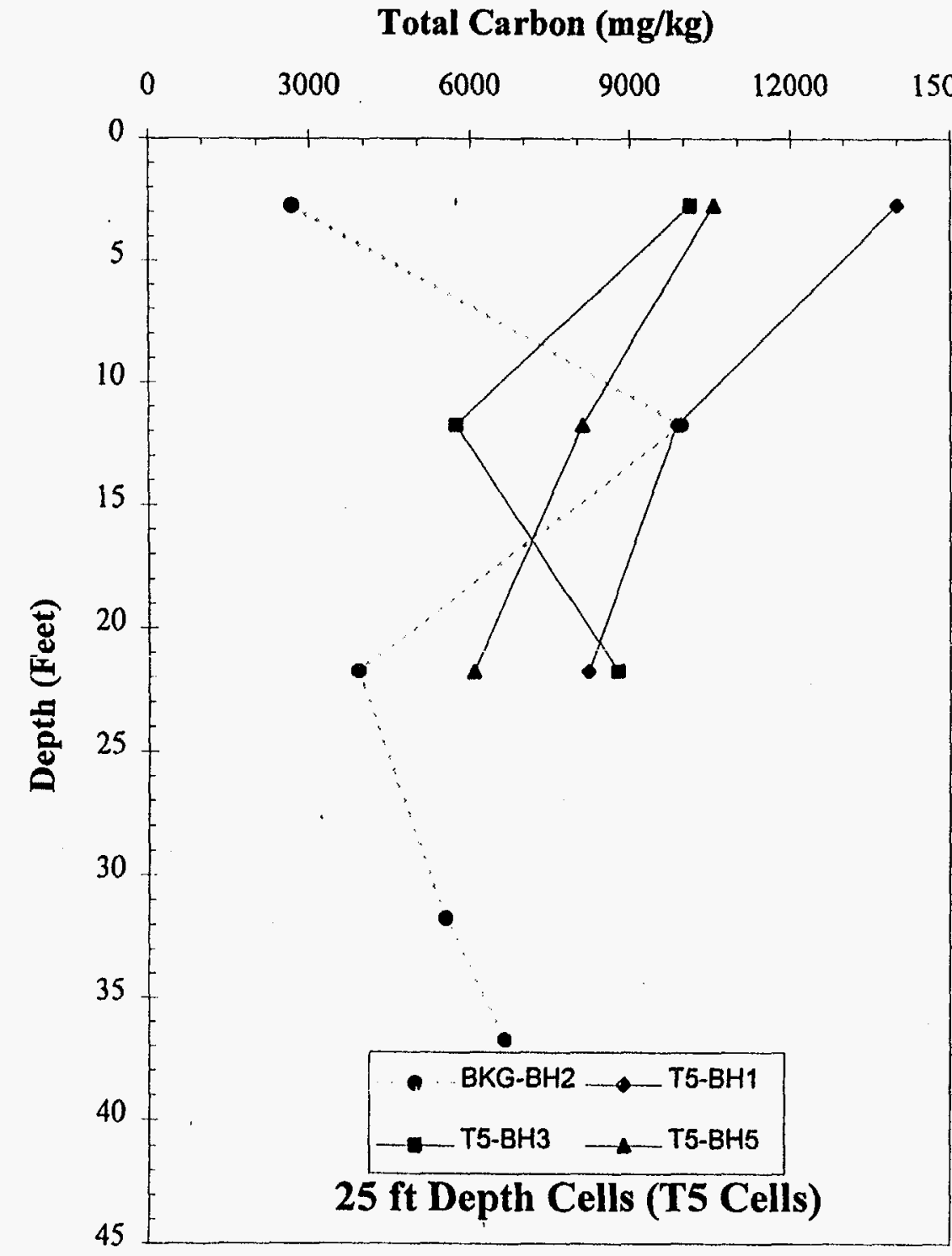

Fig. 4.10. Total carbon results for the post-treatment T5 soll borings.'

\section{Total Carbon (mg/kg)}

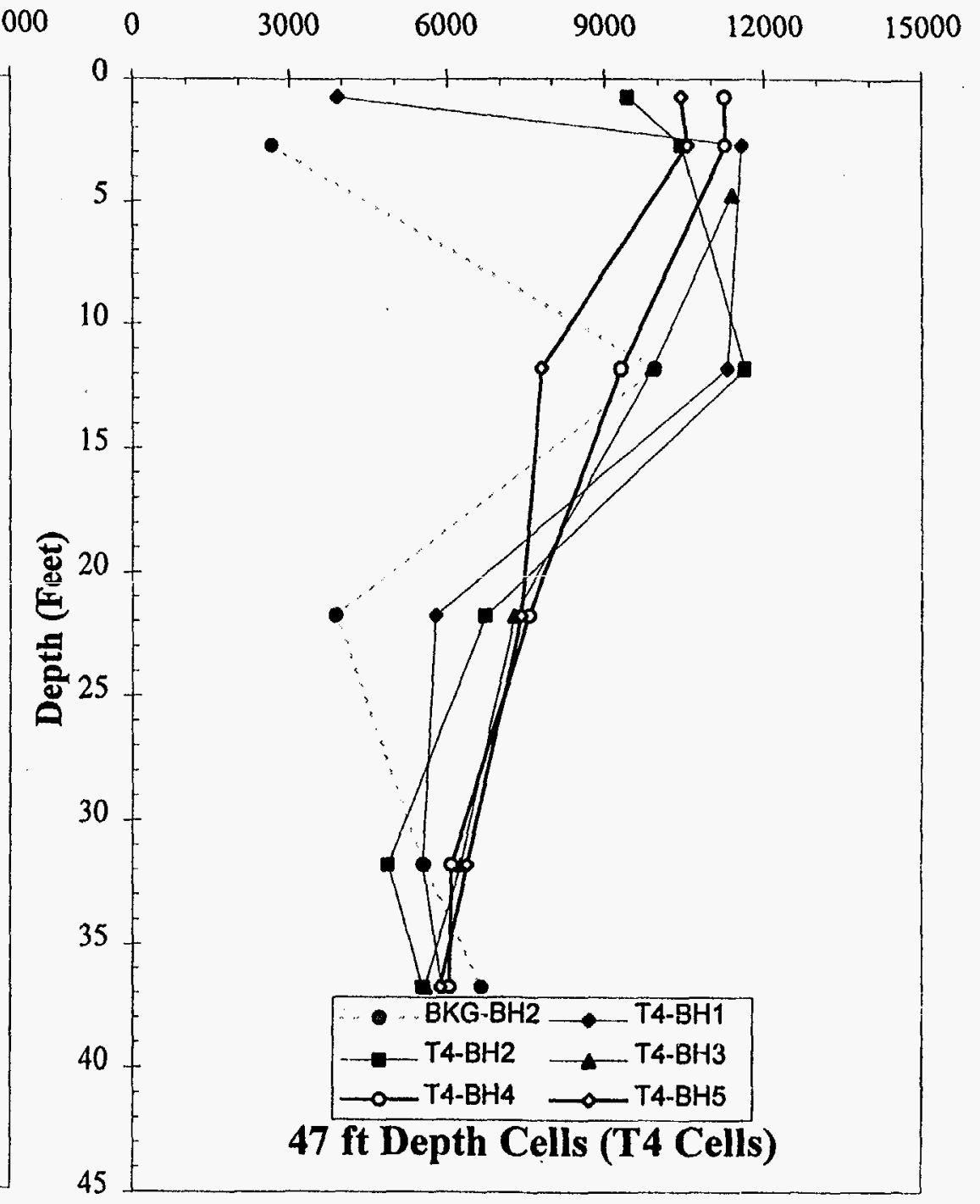

Fig. 4.11. Total carbon results for the post-treatment $\mathrm{T} 4$ soil borings. 


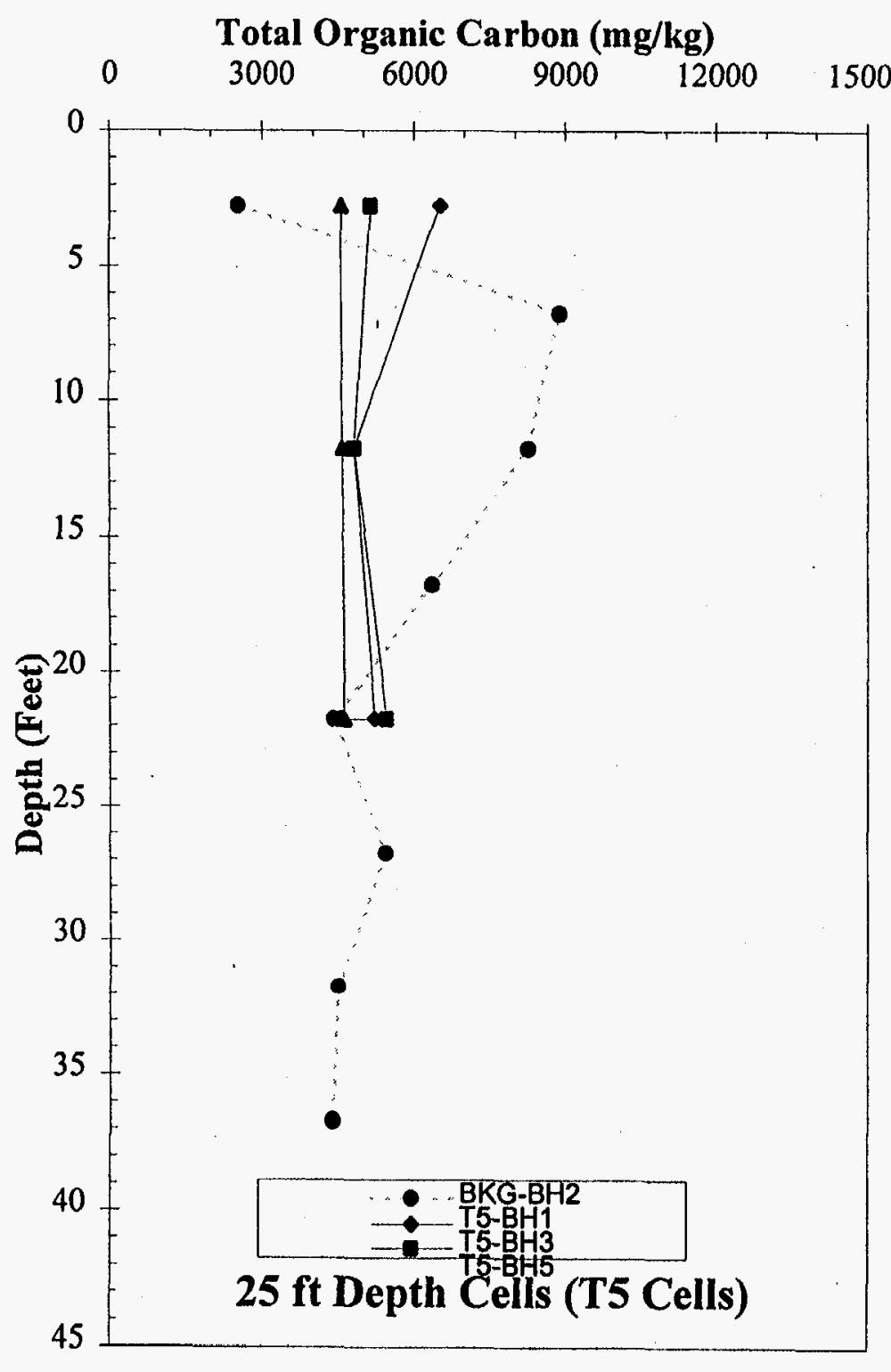

Fig. 4.12. Total organic carbon results for post-treatment T5 soil borings.
Total Organic Carbon (mg/kg)

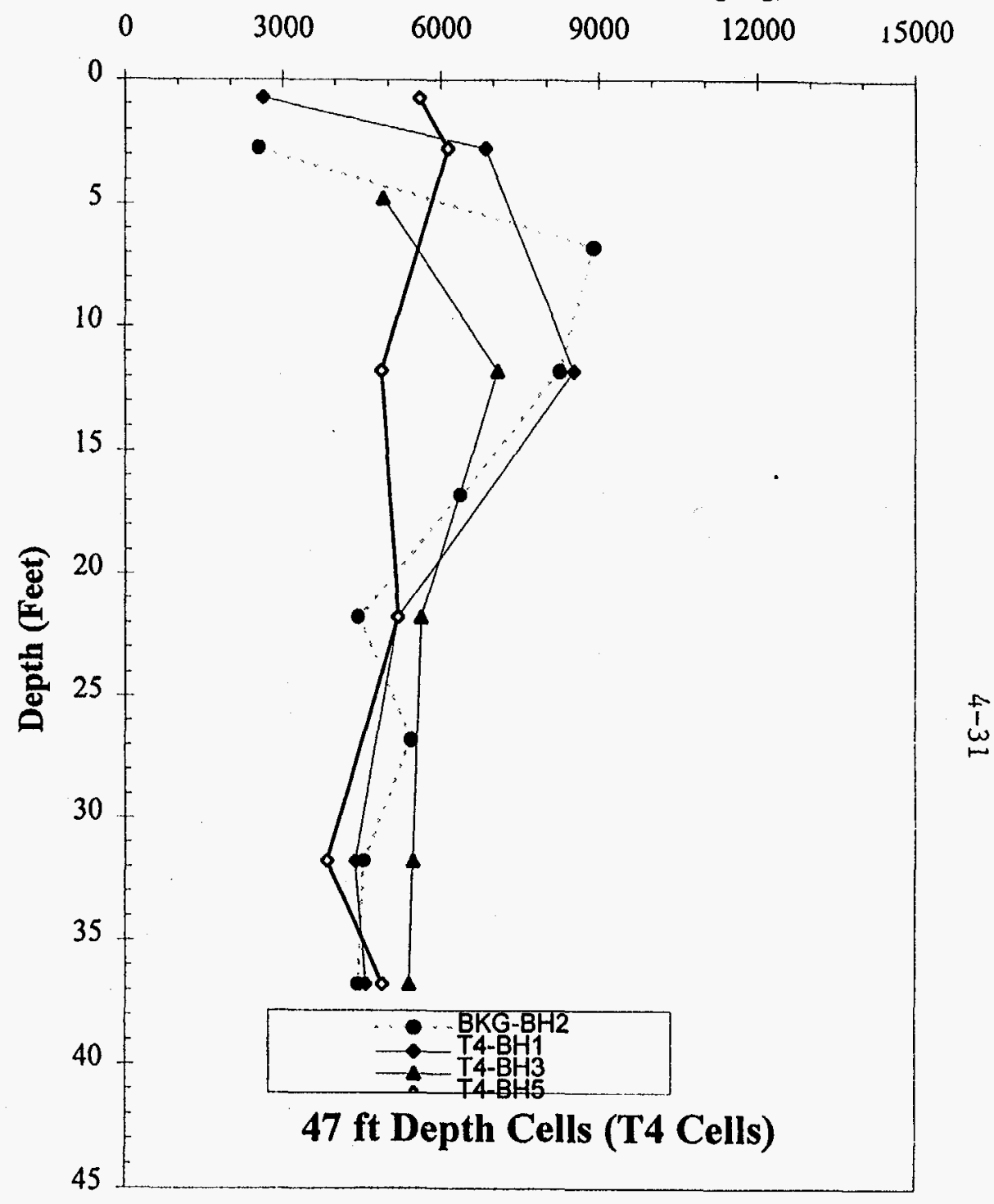

Fig. 4.13. Total organic carbon results for the post-treatment T4 soil borings. 


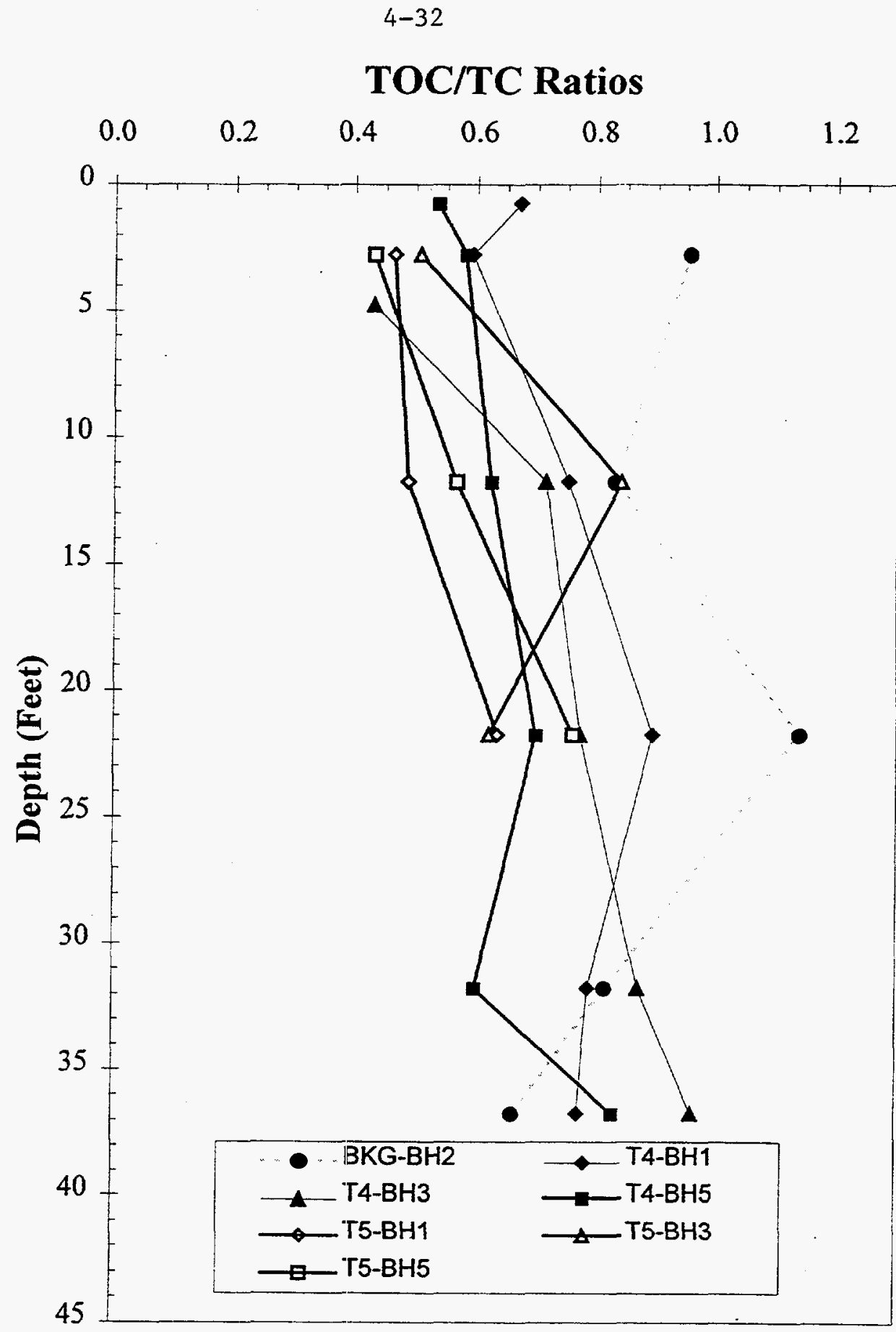

Fig. 4.14. TOC/TC ratios for selected post-treatment $\mathrm{T} 5$ and $\mathrm{T} 4$ soil borings. 
removal data reveals that borings with the lower ratios (e.g., T5B1, T4B5) also had the lowest VOC concentrations.

\subsubsection{Soil Microbial Analyses}

To examine the influence of $\mathrm{KMnO}_{4}$ on the natural microbial populations present in the soil, both anaerobic and aerobic microbial analyses were performed for the shallow and deep treatment cells. Samples for microbial assays were aseptically taken on-site and shipped back to ORNL for analysis within $72 \mathrm{~h}$. The presence of anaerobic microbes was determined by using a dilute heterotrophic media. The media was prepared by adding $0.1 \mathrm{~g} / \mathrm{L}$ glucose, $0.1 \mathrm{~g} / \mathrm{L}$ yeast extract, $0.05 \mathrm{~g} / \mathrm{L}$ peptone, 0.05 $\mathrm{g} / \mathrm{L}$ tryptone, $0.6 \mathrm{~g} / \mathrm{L}$ magnesium sulfate, $0.07 \mathrm{~g} / \mathrm{L}$ calcium chloride, $0.1 \mathrm{~g} / \mathrm{L}$ MOPS, $1 \mathrm{~mL} / \mathrm{L}$ vitamins, $10 \mathrm{~mL} / \mathrm{L}$ minerals, and $2 \mathrm{~mL} / \mathrm{L}$ resazurin. The media was heated to a boil under $\mathrm{N}_{2} / \mathrm{CO}_{2}$ conditions, $0.5 \mathrm{~g} / \mathrm{L}$ cysteine $\mathrm{HCl}$ was added, autoclaved, $2 \mathrm{mM}$ $\mathrm{PO}_{4}$ was added, and the $\mathrm{pH}$ was adjusted to 7.3 to 7.6 . The heterotrophic microbes which are capable of growing in this media are methanogens, sulfate reducers, iron reducers, and denitrifiers. For further verification of microbial presence in the media, samples were taken from the media and examined under a microscope to determine the shape and whether the bacteria were gram negative or gram positive. Table 4.9 contains the results of the anaerobic sampling. The results suggest that the $\mathrm{KMnO}_{4}$ did not have an adverse effect on the anaerobic microbes in the treated soils. The uniform distribution of anaerobic microbes in both cells, especially in the surface samples where their presence would not be expected, may be attributed to the mixing/homogenization which took place.

The presence of aerobic microbes was examined by using a plating method developed by Balkwill et al. (1989). The samples were prepared by blending in $0.1 \% \mathrm{Na}_{4} \mathrm{P}_{2} \mathrm{O}_{7}$ $(\mathrm{pH} 7)$. Serial dilutions of the blended samples were then prepared in phosphate buffered saline [ $8.3 \mathrm{mM} \mathrm{Na}_{2} \mathrm{HPO}_{4}, 16 \mathrm{mM} \mathrm{NaH}_{2} \mathrm{PO}_{4}, 0.15 \mathrm{M} \mathrm{NaCl}$ (pH 7.2)]. For plate counting, the serial dilutions were spread on a dilute medium (1\% PTYG: peptone-tryptone-yeast extract-glucose medium). Figures 4.15 and 4.16 suggest that the aerobic activity appears to be higher in the T5 cell than in the deeper T4 cell, as would be expected. The deep soils, which were initially lower in CFUs (see background boring plot), appears to have been mixed with other regions of the column with higher initial concentrations similar to the mixing/ dilution that was observed for the VOC removal. As with the anaerobic microbes, the aerobic microbes did not appear to be negatively influenced by the addition of $\mathrm{KMnO}_{4}$ to the soil. 
Table 4.9. Anaerobic microbial sample results

\begin{tabular}{|c|c|c|c|c|c|c|}
\hline Sample & Depth & $1: 1$ & $1: 10$ & $1: 100$ & $1: 1000$ & Description \\
\hline BKG-BH2 & $6.5-7.0$ & + & + & 0 & 0 & $\begin{array}{c}10 * 01 \text { gram negative, } \\
\text { long rods }\end{array}$ \\
\hline $\mathrm{BKG}-\mathrm{BH} 2$ & $26.5-27.0$ & + & + & + & 0 & No reading \\
\hline $\mathrm{BKG}-\mathrm{BH} 2$ & $31.5-32.0$ & + & + & + & + & $\begin{array}{c}10 * 03 \text { gram negative, } \\
\text { long rods }\end{array}$ \\
\hline BKG-BH2 & $36.5-37.0$ & 0 & 0 & 0 & 0 & No reading \\
\hline T5-B1 & $21.5-22.0$ & + & + & + & 0 & $\begin{array}{l}10 * 02 \text { gram negative, } \\
\text { short rods }\end{array}$ \\
\hline T5-B2 & $21.5-22.0$ & + & + & + & + & $\begin{array}{c}10 * 03 \text { gram negative, } \\
\text { short rods }\end{array}$ \\
\hline T5-B3 & $21.5-22.0$ & + & + & + & + & $\begin{array}{l}10 * 03 \text { gram negative, } \\
\text { short rods }\end{array}$ \\
\hline T5-B4 & $21.5-22.0$ & 0 & 0 & 0 & 0 & No reading \\
\hline T5-B5 & $21.5-22.0$ & + & + & + & + & $\begin{array}{l}10 * 03 \text { gram negative, } \\
\text { medium rods }\end{array}$ \\
\hline T4-B1 & $11.5-12.0$ & + & 0 & 0 & 0 & $\begin{array}{l}10 * 00 \text { gram positive, } \\
\text { medium rods }\end{array}$ \\
\hline T4-B1 & $21.5-22.0$ & + & + & 0 & 0 & $\begin{array}{l}10 * 02 \text { gram positive, } \\
\text { long and segmented rods }\end{array}$ \\
\hline T4-B1 & $36.5-37.0$ & + & + & + & 0 & $\begin{array}{l}10 * 02 \text { gram positive } \\
\text { short rods }\end{array}$ \\
\hline T4-B2 & $11.5-12.0$ & + & + & 0 & 0 & $\begin{array}{l}10 * 01 \text { gram positive, } \\
\text { medium rods }\end{array}$ \\
\hline T4-B2 & $36.5-37.0$ & + & 0 & 0 & 0 & No reading \\
\hline T4-B3 & $11.5-12.0$ & + & + & + & 0 & $\begin{array}{l}10 * 02 \text { gram negative, } \\
\text { short rods }\end{array}$ \\
\hline$\overline{\mathrm{T}} 4-\mathrm{B} 3$ & $36.5-37.0$ & + & + & 0 & 0 & $\begin{array}{l}10^{*} 01 \text { gram negative, } \\
\text { short and medium rods }\end{array}$ \\
\hline T4-B4 & $36.5-37.0$ & + & + & 0 & 0 & $\begin{array}{c}10 * 01 \text { gram negative, } \\
\text { cocci }\end{array}$ \\
\hline T4-B5 & $11.5-12.0$ & + & + & 0 & 0 & $\begin{array}{l}10^{*} 01 \text { gram negative, } \\
\text { long and short rods; gram } \\
\text { positive, long rods cocci }\end{array}$ \\
\hline T4-B5 & $36.5-37.0$ & + & + & 0 & 0 & $\begin{array}{l}10 * 01 \text { gram positive, } \\
\text { cocci; gram negative, } \\
\text { long rods }\end{array}$ \\
\hline
\end{tabular}




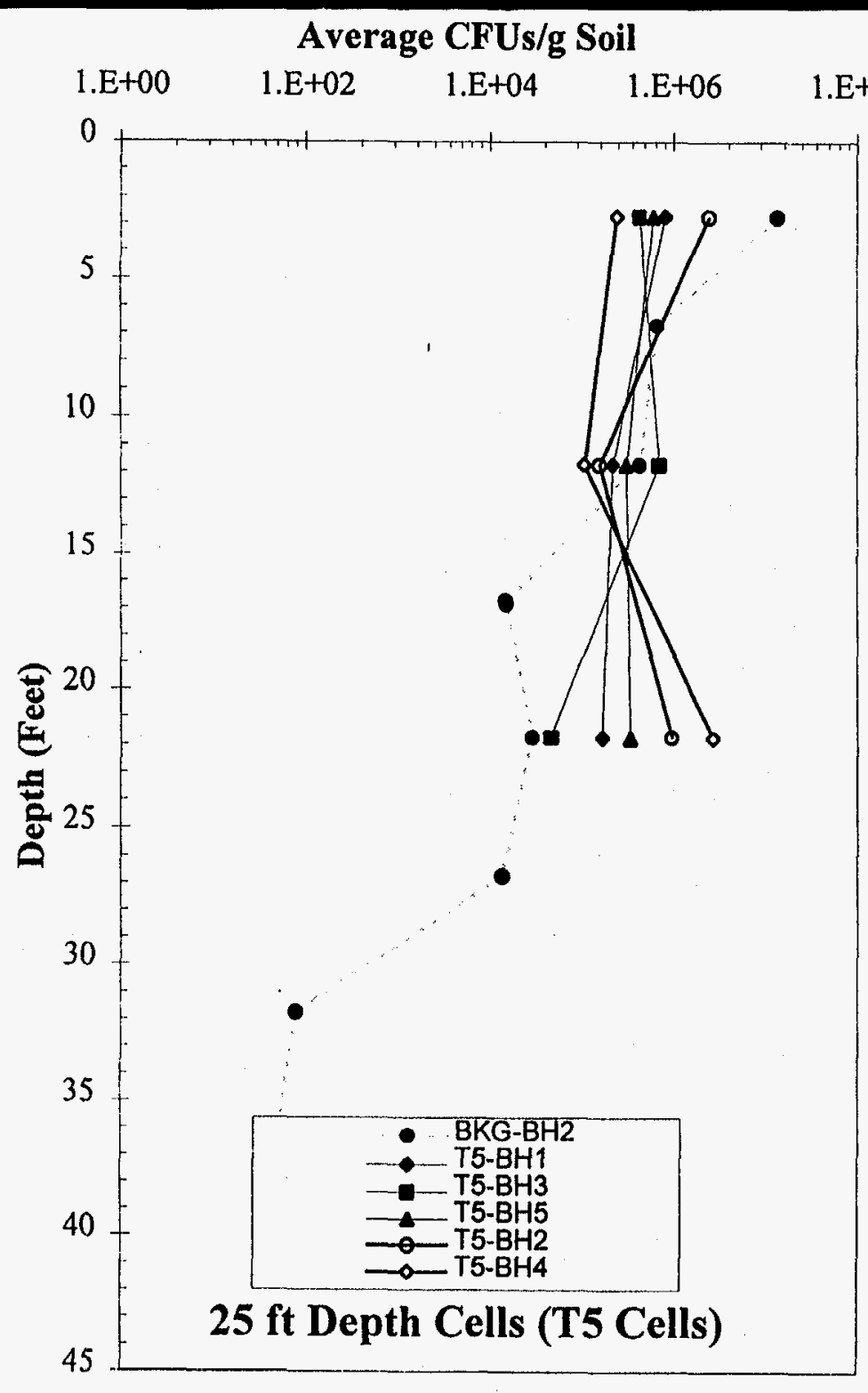

Fig.4.15. Aerobic bacteria results for the post-treatment T5 soil borings.

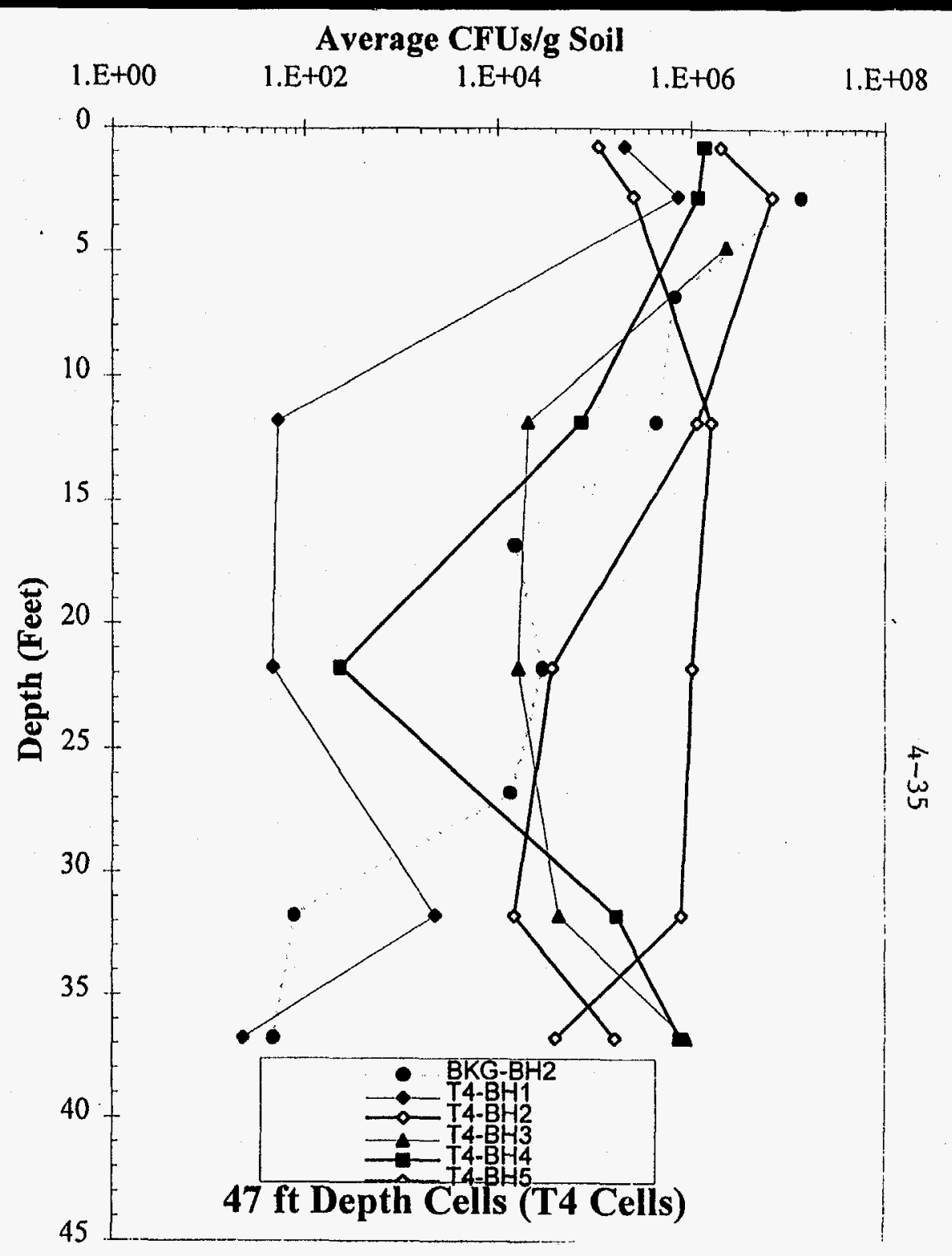

Fig. 4.16. Aerobic bacteria results for the post-treatment $\mathrm{T} 4$ soil borings. 


\subsubsection{Evaluation of Cost for DSM[ Using $\mathrm{KMnO}_{4}$}

Geo-Con estimated the cost of treatment using $\mathrm{KMnO}_{4}$ to be $\$ 128 / \mathrm{yd}^{3}$ of soil assuming $30,000 \mathrm{yd}^{3}$ of soil and a treatment depth of $30 \mathrm{ft}$. This is based on a equipment and crew cost of $\$ 43 / \mathrm{yd}^{3}$, plus a material $\left(\mathrm{KMnO}_{4}\right)$ cost of $\$ 46 / \mathrm{yd}^{3}$ (for a $5 \%$ slurry of $\mathrm{KMnO}_{4}$ ), and a multiplier of 1.45 to cover overhead, safety, quality control, supervision, and profit.

\subsection{DSM/MRVS and Powdered Calcium Oxide Injection Demonstration Results}

\subsubsection{Background Information}

The demonstration project was originally designed to evaluate soil mixing coupled with MRVS which had proven to be successful at removing VOCs in unsaturated silty clays (West et al. 1995). Treatability studies using soil cores from KCP, however, indicated that MRVS coupled with calcium oxide injection would improve the TCE removal efficiency in saturated silty clay soils (West et al. 1995). The hydration of the calcium oxide upon contact with wet soil reduces the amount of free moisture, thereby increasing soil air porosity and the friability of the soil. Results of the treatability study indicated removal rates of up to $90 \%$ could be achieved using MRVS in soils conditioned with calcium oxide which compared with removal rates of less than $40 \%$ using MRVS in unconditioned soils. The treatability study concluded that the successful implementation of the MRVS coupled with calcium oxide delivery would depend on the development of equipment that is capable of delivering powdered calcium oxide during soil mixing. Such equipment has been used already in the geotechnical arena (Broms 1991). It should be noted that the equipment used by Broms (1991) was designed for stabilization of soil with lime columns and the largest diameter mixing apparatus used did not exceed $3 \mathrm{ft}$. Additionally, the calcium oxide was conveyed using an auger feed mechanism to lift the powder to top of the kelly bar where it was gravity-fed directly out of the bottom of the mixing tool. However, to convey the volume of calcium oxide needed to achieve a 10\% mass loading level for the DSM/MRVS demonstration, an entirely different approach was conceived. The system used was comprised of a 30 ton silo equipped with a rotary valve that delivered $130 \mathrm{lbs}$ of powdered lime per revolution into a dry conveyor. The second air compressor forced the lime from the dry conveyor to a " $\mathrm{y}$ " in the main hose where air from the first compressor would assist to push the powder through the main hose to the top of the kelly bar and eventually out through the nozzles in the mixing blade. 
The first attempt to deliver lime to the subsurface resulted in clogging of the lines with lime due to high backpressure inherent in the delivery system. The hoses were cleared and a number of alternate injection sequences were attempted with the mixing tool at various depths and with air pressure over 100 psi and air flows over $3000 \mathrm{~cm}$, all of which resulted in repeated clogging. Although the expected maximum backpressure had been calculated by the subcontractor be $30 \mathrm{psi}$, the combination of system and geostatic pressure could not be overcome with 100 psi of air pressure-which was the operational limit of the dry conveyor system. It should be noted that the system was able to convey lime to the mixing tool when the latter was above ground and not subjected to any geostatic pressure. Thus, after the repeated attempts to inject lime, it was agreed by all parties that the lime injection could not be performed and that the scope of the DSM/MRVS would be limited to one test cell ( 3 columns) to $25 \mathrm{ft}$ using heated air.

Therefore, a key question answered by the DSM/MRVS demonstration was that the dry lime conveyor system as configured with the mixing tool was not a viable mechanism to deliver calcium oxide. However, it is evident that the system used could be redesigned with fewer turns and constrictions. For example, if the 90 degree turn at the bottom of the kelly bar into the air box on the mixing blade followed by another 90 degree turn to exit the air box through the nozzles were eliminated by routing the powder straight through the bottom of the pilot bit, a great deal of backpressure would be eliminated. This was suggested as a possibility but was deemed untenable by Geo-Con due to the design of the mixing tool in use and all other available tools.

\subsubsection{DSM/MRVS Operational Information}

DSM/MRVS was conducted July 19 and 20 in three overlapping test columns (T7C1, T7C2, and T7C3) with 8-ft diameters and 25-ft depths. Column T7C3 was treated first and was followed by column $\mathrm{T} 3 \mathrm{C} 1$, and finally column $\mathrm{T} 3 \mathrm{C} 2$. Figure 4.17 illustrates the location and orientation of the three columns. Following are brief chronological summaries of the mixing efforts conducted as part the DSM/MRVS demonstration. 

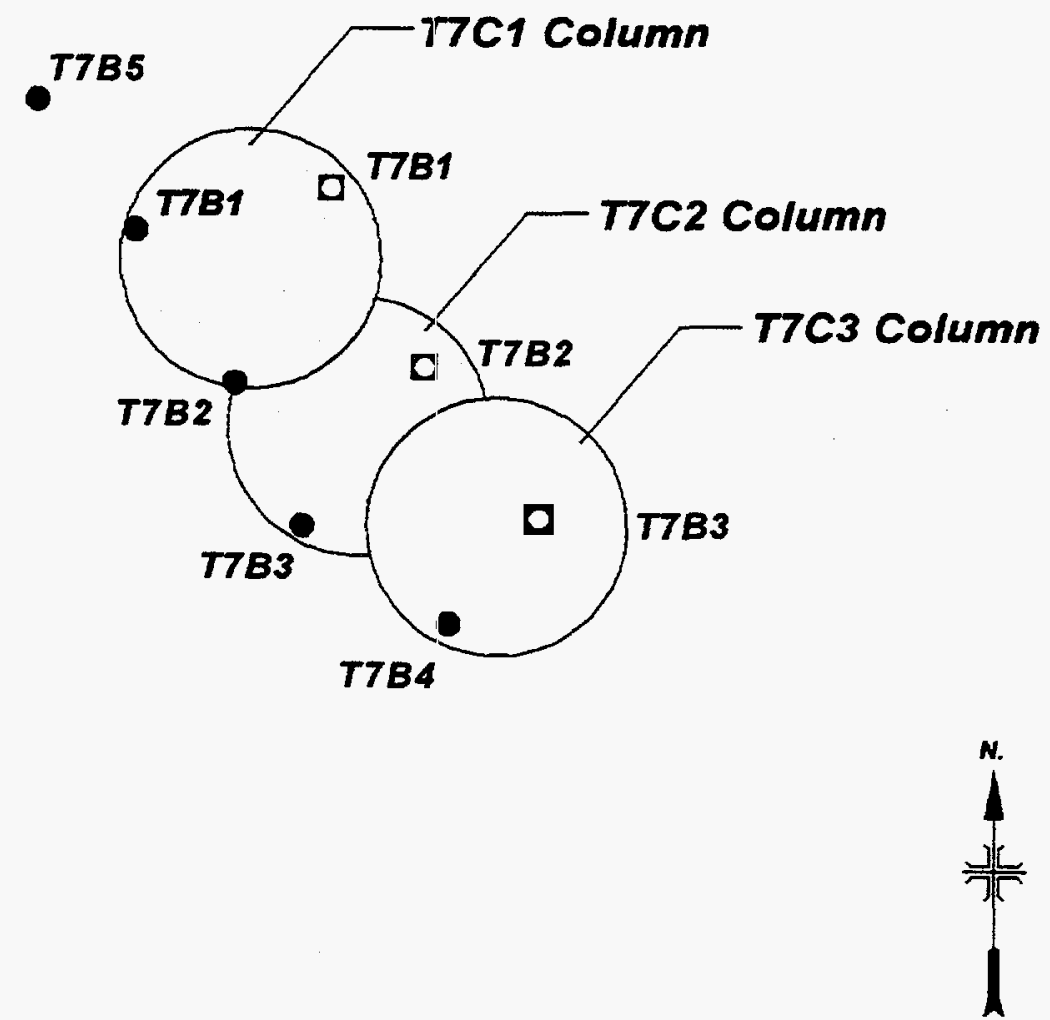

- Pre-characterization borehole

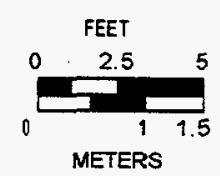

- Post-characterization borehole

DSMO11a

Fig. 4.17. T7 cell layout with soil boring locations. 


\section{T7C3 Column}

Elapsed time Process description

0 to $20 \mathrm{~min} \quad$ An 8-ft diameter hole drilled with air $(1500$ to $1700 \mathrm{cfm})$ to a depth of $25 \mathrm{ft}$, continued collapsed off gas tubing prevails.

20 to $51 \mathrm{~min} \quad$ Attempt powdered lime injection from 25 to $22 \mathrm{ft}$ but cannot overcome backpressure, no lime delivered.

51 to $71 \mathrm{~min} \quad$ Mix with air $(1700 \mathrm{cfm})$ from $22 \mathrm{ft}$ to surface.

71 to $82 \mathrm{~min} \quad$ Reconfigure air lines to maximize pressure and flow (100 psi, $3000 \mathrm{cfm}$ ).

82 to $89 \mathrm{~min} \quad$ Attempt powdered lime delivery from surface to $4 \mathrm{ft}$, cannot overcome backpressure, pull auger to surface and successfully test delivery system above ground.

89 to $257 \mathrm{~min}$ Change nozzle size from 0.5 in. to 1 in. to reduce backpressure.

257 to 277 Attempt powdered lime delivery from surface to $7 \mathrm{ft}$, cannot overcome backpressure pull auger to surface .

277 to $348 \mathrm{~min}$ Change nozzle size back to 0.5 in. to proceed with air stripping only.

348 to $369 \mathrm{~min} \quad$ Mix column with air $(1700 \mathrm{cfm})$ from surface to $25 \mathrm{ft}$.

369 to $388 \mathrm{~min} \quad$ Mix column with air $(1700 \mathrm{cfm})$ from $25 \mathrm{ft}$ to $1 \mathrm{ft}$.

388 to $416 \mathrm{~min}$ Mix column with air $(1700 \mathrm{cfm})$ from $1 \mathrm{ft}$ to $25 \mathrm{ft}$.

416 to $427 \mathrm{~min}$ Mix column with air $(1700 \mathrm{cfm})$ from $25 \mathrm{ft}$ to $1 \mathrm{ft}$.

427 to $448 \mathrm{~min} \quad$ Mix column with air $(1700 \mathrm{cfm})$ from $1 \mathrm{ft}$ to $25 \mathrm{ft}$.

448 to $460 \mathrm{~min} \quad$ Mix column with air $(1700 \mathrm{cfm})$ from $25 \mathrm{ft}$ to surface, end of mix.

Following treatment of $\mathrm{T} 7 \mathrm{C} 3$, the mixing apparatus was moved and located over the $\mathrm{T} 7 \mathrm{C} 1$ column at the north end of the T7 cell.

\section{$\underline{\text { T7C1 Column }}$}

Elapsed time Process description

0 to $9 \mathrm{~min} \quad$ Prepare for drilling.

9 to $44 \mathrm{~min} \quad$ An 8-ft diameter hole drilled with air $(1500$ to $1700 \mathrm{cfm})$ to a

44 to $55 \mathrm{~min} \quad$ Mix with air $(1700 \mathrm{cfm})$ from $25 \mathrm{ft}$ to $1 \mathrm{ft}$.

55 to $81 \mathrm{~min} \quad$ Mix with air $(1700 \mathrm{cfm})$ from $1 \mathrm{ft}$ to $25 \mathrm{ft}$.

81 to $87 \mathrm{~min} \quad$ Mix column with air $(1700 \mathrm{cfm})$ from $25 \mathrm{ft}$ to $1 \mathrm{ft}$.

87 to $108 \mathrm{~min} \quad$ Mix column with air $(1700 \mathrm{cfm})$ from $1 \mathrm{ft}$ to $25 \mathrm{ft}$.

108 to $114 \mathrm{~min}$ Mix column with air $(1700 \mathrm{cfm})$ from $25 \mathrm{ft}$ to $1 \mathrm{ft}$. 
114 to $131 \mathrm{~min}$

131 to $138 \mathrm{~min}$

138 to $152 \mathrm{~min}$
Mix column with air $(1700 \mathrm{cfm})$ from $1 \mathrm{ft}$ to $25 \mathrm{ft}$.

Mix column with air $(1700 \mathrm{cfm})$ from $25 \mathrm{ft}$ to $1 \mathrm{ft}$.

Raise auger, blow out ports with air, end of mix.

Following treatment of the $\mathrm{T} 7 \mathrm{C} 1$ column, the mixing apparatus was moved and located over the T7C2 column located in the center of the T7 cell.

\section{T7C2 Column}

Elapsed time Process description

0 to $20 \mathrm{~min} \quad$ An $8-\mathrm{ft}$ diameter hole drilled with air $(1500$ to $1700 \mathrm{cfm})$ to a depth of $25 \mathrm{ft}$, off gas tubing is collapsed.

20 to $27 \mathrm{~min} \quad$ Mix with air $(1700 \mathrm{cfm})$ from $25 \mathrm{ft}$ to $1 \mathrm{ft}$.

27 to $108 \mathrm{~min} \quad$ Break for lunch and minor rig repairs.

108 to $133 \mathrm{~min} \quad$ Mix with air $(1700 \mathrm{cfm})$ from $1 \mathrm{ft}$ to $25 \mathrm{ft}$.

133 to $151 \mathrm{~min}$

Mix column with air $(1700 \mathrm{cfm})$ from $25 \mathrm{ft}$ to $1 \mathrm{ft}$.

151 to $173 \mathrm{~min}$

Mix column with air $(1700 \mathrm{cfm})$ from $1 \mathrm{ft}$ to $25 \mathrm{ft}$.

173 to $188 \mathrm{~min}$

Mix column with air $(1700 \mathrm{cfm})$ from $25 \mathrm{ft}$ to $1 \mathrm{ft}$.

188 to $211 \mathrm{~min}$

Mix column with air $(1700 \mathrm{cfm})$ from $1 \mathrm{ft}$ to $25 \mathrm{ft}$.

211 to $230 \mathrm{~min}$

Mix column with air $(1700 \mathrm{cfm})$ from $25 \mathrm{ft}$ to $1 \mathrm{ft}$, end of mix.

Table 4.10 ists the operational data from the thermal vapor stripping treatment cell. During the MRVS demonstration in the T7 cell, an estimated total of $16,563 \mathrm{~m}^{3}$ $\left(584,800 \mathrm{ft}^{3}\right)$ of air with an average temperature of $85^{\circ} \mathrm{C}\left(185^{\circ} \mathrm{F}\right)$ was injected into the T7 cell.

Table 4.10. DSML/MRVS operational data

\begin{tabular}{|c|c|c|c|}
\hline $\begin{array}{c}\text { Treatment } \\
\text { column }\end{array}$ & Mix date & $\begin{array}{c}\text { Air injected, } \\
\mathrm{m}^{3}\left(\mathrm{ft}^{3}\right)\end{array}$ & No. of passes \\
\hline $\mathrm{T} 7 \mathrm{C} 1$ & $7 / 20 / 96$ & $3996\left(141,100 \mathrm{ft}^{3}\right)$ & 4 \\
\hline$-\mathrm{T} 7 \mathrm{C} 2$ & $7 / 20 / 96$ & $7173\left(253,300 \mathrm{ft}^{3}\right)$ & 4 \\
\hline $\mathrm{T} 7 \mathrm{C} 3$ & $7 / 19 / 96$ & $5932\left(190,400 \mathrm{ft}^{3}\right)$ & 4 \\
\hline
\end{tabular}

Due to the close proximity of the colurnns, post-treatment sampling could not safely be conducted until all three columns had been mixed. This resulted in a minimum delay of three days between mixing and sampling. Post-treatment sampling information for each soil boring in the $\mathrm{T} 7$ cell is presented in Table 4.11. The soil boring locations for the T7 cell are presented in Fig. 4.17. 
Table 4.11. MRVS post-treatment sampling information

\begin{tabular}{|c|c|c|c|}
\hline $\begin{array}{c}\text { Soil } \\
\text { boring }\end{array}$ & $\begin{array}{c}\text { Associated } \\
\text { column }\end{array}$ & $\begin{array}{c}\text { Sampling } \\
\text { date }\end{array}$ & $\begin{array}{c}\text { Days after } \\
\text { mixing }\end{array}$ \\
\hline BKG-BH2 & NA & $7 / 16 / 96$ & NA \\
\hline T7B1 & T7C1 & $7 / 23 / 96$ & 3.1 \\
\hline T7B2 & T7C2 & $7 / 23 / 96$ & 2.8 \\
\hline T7B3 & T7C3 & $7 / 23 / 96$ & 3.8 \\
\hline
\end{tabular}

n.a.: not applicable

\subsubsection{Post-Treatment VOC Results From MRVS Cell}

As previously discussed, the post-treatment boring locations were not intended to replicate the pre-treatment borings due to the redistributing effects of the mixing action.

The post-treatment samples were, however, collected in similar fashion and locations as the pre-treatment samples. Furthermore, the inherent heterogeneity in the pretreatment soil sample data combined with the redistribution of soil characteristics in the post-treatment soil sample data resulting from the mixing effects, required that the data sets be averaged to provide useful interpretation of the treatment effectiveness. The pre- and post-treatment VOC results for the T7 cell are presented in Appendices $B$ and $E$ respectively. It should be noted that no detectable levels of cis-1,2-DCE were reported in the pre- and post-treatment data. Thus, the VOC mass removal efficiency discussion is limited to TCE only.

The average TCE concentration for each soil boring was calculated by summing the depth-specific TCE values and dividing by the number of depth intervals in each boring. The data were treated in the same manner as the other previously discussed VOC data from the bioaugmentation and oxidation cells. Using the data in Appendices B and E, pre- and post-treatment average TCE concentrations in soil for the $T 7$ cell are presented in Table 4.12. The soil boring locations for the $T 7$ cell cells are presented in Fig. 4.17. 
Table 4.12. Pre- and post-treatment average TCE concentrations in $\rceil\lceil 7$ Cell borings

\begin{tabular}{|c|c|c|c|c|c|c|c|c|c|c|c|}
\hline \multicolumn{4}{|c|}{ T7C1 Column } & \multicolumn{4}{|c|}{ T7C2 Column } & \multicolumn{4}{|c|}{ T7C3 Column } \\
\hline $\begin{array}{l}\text { Pre- } \\
\text { treat } \\
\text { boring } \\
\text { No. }\end{array}$ & $\begin{array}{l}\text { Aver- } \\
\text { age } \\
\text { TCE, } \\
\mathrm{mg} / \mathrm{kg}\end{array}$ & $\begin{array}{l}\text { Post- } \\
\text { treat } \\
\text { boring } \\
\text { No. }\end{array}$ & $\begin{array}{l}\text { Aver- } \\
\text { age } \\
\text { TCE, } \\
\mathrm{mg} / \mathrm{kg}\end{array}$ & $\begin{array}{l}\text { Pre- } \\
\text { treat } \\
\text { boring } \\
\text { No. }\end{array}$ & $\begin{array}{l}\text { Aver- } \\
\text { age } \\
\text { TCE, } \\
\mathrm{mg} / \mathrm{kg}\end{array}$ & $\begin{array}{l}\text { Post- } \\
\text { treat } \\
\text { boring } \\
\text { No. }\end{array}$ & $\begin{array}{l}\text { Aver- } \\
\text { age } \\
\text { TCE, } \\
\mathrm{mg} / \mathrm{kg}\end{array}$ & $\begin{array}{l}\text { Pre- } \\
\text { treat } \\
\text { boring } \\
\text { No. }\end{array}$ & $\begin{array}{l}\text { Aver- } \\
\text { age } \\
\mathrm{TCE} \text {, } \\
\mathrm{mg} / \mathrm{kg}\end{array}$ & $\begin{array}{l}\text { Post- } \\
\text { treat } \\
\text { boring } \\
\text { No. }\end{array}$ & $\begin{array}{l}\text { Aver- } \\
\text { age } \\
\text { TCE, } \\
\text { mgkg }\end{array}$ \\
\hline T7B1 & 11.7 & T7B1 & 5.6 & T7B2 & 31.7 & T7B2 & 5.6 & T7B4 & 7.6 & T783 & 2.6 \\
\hline T7B2 & 11.8 & & & T7B3 & 8.5 & & & & & & \\
\hline
\end{tabular}

The average TCE concentrations for each pre-treatment boring in each of the T7 columns shown in Table 4.12 were averaged to arrive at an average pre-treatment TCE concentration for each column. The respective average pre-treatment TCE concentrations for the $\mathrm{C} 1, \mathrm{C} 2$ and $\mathrm{C} 3$ columns are $11.8,20.1$, and $7.6 \mathrm{mg} / \mathrm{kg}$, which yield an average pre-treatment TCE concentration of $13.2 \mathrm{mg} / \mathrm{kg}$ for the T7 cell. The mass of soil for the $T 7$ cell was calculated using three $25 \mathrm{ft}$ deep columns with $8 \mathrm{ft}$ diameters, a $60 \%$ overlap for the center column, a particle density of $2.65 \mathrm{~g} / \mathrm{cm}^{3}$ and an estimated porosity of $30 \%$. The resulting mass of soil in the T7 cell is $158,548 \mathrm{~kg}$ of soil which when multiplied by the average TCE concentration of $13.2 \mathrm{mg} / \mathrm{kg}$ yields a total pre-treatment TCE mass of $2.1 \mathrm{~kg}$ in the $\mathrm{T} 7$ cell.

The average TCE concentrations frorn each of the post-treatment soil borings in the $\mathrm{T} 7$ columns shown in Table 4.12 were treated in the same fashion and yield respective average post-treatment TCE concentrations for the C1, C2 and C3 columns of 5.6, 5.6 , and $2.6 \mathrm{mg} / \mathrm{kg}$; which yield an average post-treatment TCE concentration of $4.6 \mathrm{mg} / \mathrm{kg}$ for the $\mathrm{T} 7 \mathrm{cell}$. The estimated total mass of post-treatment TCE in the T7 cell is calculated to be $0.73 \mathrm{~kg}$ using the same column dimensions and previously mentioned parameters. Comparing the pre- and post-treatment values of 2.1 and 0.73 $\mathrm{kg}$ TCE indicates an overall removal rate of $65 \%$ or $1.4 \mathrm{~kg}$ of TCE from the T7 cell.

Based on the treatability study results (West et al. 1995) which used the same KCP soils-to achieve TCE removal rates of $90 \%$ or better with the addition of calcium oxide to condition the soil by reducing the moisture content, it could be concluded that the field demonstration had the potential to achieve similar removal rates had the dry powder delivery system been successful.

While the $65 \%$ reduction in TCE falls below the overall treatment objective of $70 \%$, it is useful to note that TCE concentrations verify that VOC reductions did occur. Also, as previously discussed, it is useful to note that different TCE mass reductions could be represented with the same data set. For example, the values could be calculated on a per column basis rather than a per cell basis and show a range of TCE 
removal efficiency from $53 \%$ in $\mathrm{C} 1$ to $72 \%$ in $\mathrm{C} 2$. However, due to the previously discussed aspects associated with heterogeneity in soil sampling and redistribution of soil characteristics introduced by the soil mixing process, it is difficult to draw any significant conclusion from this approach. Moreover, all of the pre-and posttreatment data from the $T 7$ cell suggests that treatment did in fact take place and, thus, indicate that treatment of the data on a per-cell basis is appropriate.

When a straightforward comparison between the MRVS and $\mathrm{KMnO}_{4}$ demonstration results for unsaturated soils are made it would appear that the mass of TCE reduced by the vapor stripping $(65 \%)$ compares favorably with that reduced by chemical oxidation in the shallow test cell $(83 \%)$. It should be noted, however, that the comparison applies to unsaturated soil only. Additionally, had the shallow chemical oxidation cell been exposed to the degree of vapor stripping applied in the MRVS test cell, a higher TCE mass reduction would have been expected in the former cell.

Post-treatment groundwater samples were to be collected after installing piezometers into the boreholes created as a result of the sampling event. Although piezometers were installed in boreholes T7B1, T7B2, and T7B3, the piezometers were still dry after waiting 24 hours, thus, no groundwater samples were collected.

\subsubsection{Evaluation of Cost for DSM Using MRVS}

Geo-Con estimated the cost of treatment using hot air injection alone to be $\$ 62 / \mathrm{yd}^{3}$ of soil assuming $30,000 \mathrm{yd}^{3}$ of soil and a treatment depth of $30 \mathrm{ft}$. This is based on equipment and crew costs of $\$ 43 / \mathrm{yd}^{3}$, plus a multiplier of 1.45 to cover overhead, safety, quality control, supervision, and profit. 


\section{CONCLUSIONS}

The DSM technology demonstration performed at the KCP answered numerous questions regarding the efficiency, costs, and equipment limitations of delivering three in situ treatment reagents in stiff clay soils. As a result of the demonstration the following answers were provided:

- It is possible to drill to $47 \mathrm{ft}$ in stiff clay soils and mix such soils efficiently using an $8 \mathrm{ft}$ diameter mixing tool.

- The biggest limitation for drilling and mixing to $47 \mathrm{ft}$ in KCP soils is fluid control when using water for initial drilling and liquid reagent injection during mixing. In either case, the fluids must be introduced at lower pumping rates to prevent their return to the surface and flooding of the work site.

- The most serious equipment limitation regarding dry powder injection was overcoming system and geostatic back pressure build up which leads to clogging of lines. With additional testing and development this limitation could be overcome and provide a cost effective in situ treatment technology.

- TCE mass reductions of $70 \%$ or more were demonstrated by coupling DSM with chemical oxidation using $\mathrm{KMnO}_{4}$. Results of the laboratory treatability study suggested that TCE removals greater than $90 \mathrm{wt} \%$ could be achieved using $\mathrm{KMnO}_{4}$ solutions of at least $4 \mathrm{wt} \%$, with oxidant loadings greater than $16 \mathrm{~g}$ $\mathrm{KMnO}_{4} / \mathrm{kg}$ soil. During the demonstration, up to $69 \%$ TCE removal in saturated soil and $83 \%$ TCE removal in unsaturated soil were achieved using a much lower average loading $\left(6 \mathrm{~g} \mathrm{KMnO}_{4} / \mathrm{kg}\right.$ soil). A lower oxidant loading was chosen for the field due to the limitation of the volume of oxidant which could be added to the low permeable soils. Thus, the $60 \%$ reduction in the oxidant loading used in the field still resulted in acceptable TCE reductions.

- TCE mass reductions of $65 \%$ were demonstrated by coupling DSM with MRVS in soils with moisture content averaging $19 \%$. Had the injection of powdered lime been achieved, treatability studies indicated that the mass reduction of TCE could be as high as $90 \%$.

- TCE mass reductions of $38 \%$ were demonstrated by coupling DSM with bioaugmentation in soil TCE concentrations that are considered toxic to the injected bacterial population. Had the bioaugmentation been performed in soil with lower TCE concentrations, the mass removal rate may have reached the $70 \%$ objective. 
- Based on the results of the DSM/Bioaugmentation demonstration it can be concluded that the chemical, physical and biological properties of the soil remain intact.

- Viable TCE degrading bacteria were recoverable from the upper treatment depths ( 0 to $13 \mathrm{ft}$ bgs) for at least 10 days suggesting that TCE degradation could be continued if other limiting factors such as oxygen were augmented.

- Post-treatment microbiological studies determined that survivability of G4 below $13.5 \mathrm{ft}$ was minimal probably due to the high TCE concentrations (up to 527 $\mathrm{mg} / \mathrm{kg}$ ) encountered at these depths. However, laboratory testing of surviving bacteria demonstrated successful degradation of TCE confirming that G4 was added to the subsurface and survived the DSM process where the TCE concentrations did not have toxic effects.

- Based on the results and observations of the field demonstration it can be concluded that treatment reagent migration beyond the boundary of the soil column is minimal. Reagent migration is limited to areas with inherent preferential flow networks such as fractures which are exploited and magnified by the high pressure/high volume flow of air used during initial drilling of the soil columns.

- Based on the results of the $\mathrm{DSM} / \mathrm{KMnO}_{4}$ demonstration it can be concluded that the physical and biological properties of the soil remain essentially intact. The results from both anaerobic and aerobic bacteria sampling indicate that neither were greatly influenced by the addition of the oxidant. The presence of the anaerobic microbes and the $\mathrm{CFU}$ values for the aerobic microbes suggest that the $\mathrm{KMnO}_{4}$ treatment could be amended with a microbial remediation treatment. Microbial activity also appears to be more evenly distributed with soil depth as a result of the mixing process. Due to the low oxidant loading used and the high organic content of the pre-treated soil, $\mathrm{KMnO}_{4}$ was not observed in the posttreatment samples, and a SOM fraction remained in the soils following treatment. Soil moisture was also affected during DSM, the average background soil moisture of $28 \%$ increased to $34 \%$ and $41 \%$ for the shallow and deep treatment cells, respectively. Increases in soil $\mathrm{pH}$ were also observed, due to addition of $\mathrm{KMnO}_{4}$, and these increases were not greater than the $\mathrm{pH}$ of the oxidant which was added.

- Based on the results of the $\mathrm{DSM} / \mathrm{KMnO}_{4}$ demonstration it can be concluded that the treatment reagent was well distributed in the soil as manifested by the distribution of $\mathrm{Mn}$. 
- Based on the results of the DSM/KMnO ${ }_{4}$ demonstration it can be concluded that treatment levels predicted from laboratory treatability studies can be achieved in the field.

- Although treatment costs using $\mathrm{KMnO}_{4}$ are estimated to be $\$ 128 / \mathrm{yd}^{3}$ of soil which is roughly twice the cost of the other treatments (bioaugmentation was $\$ 77 / \mathrm{yd}^{3}$ and MRVS was $\$ 62 \mathrm{yd}^{3}$ ), it should be noted that the oxidation treatment was also applied in both saturated and unsaturated conditions and had the highest removal efficiency. 


\section{REFERENCES}

Balkwill, D.L., J.K. Fredrickson, and J.M. Thomas. 1989. Vertical and horizontal variations in the physiological diversity of the aerobic chemoheterotrophic bacterial microflora in deep southeast coastal plain subsurface sediments. Applied Environmental Microbiology, 55:1058-1065.

Bochner, B. 1989. Sleuthing our bacterial identities. Nature (London), 339:157158.

Broms, B.B. 1991. Stabilization of soil with lime columns, in Foundation Engineering Handbook. Fang, H-Y. (Ed.) Van Nostrand Reinhold, New York.

Carter, M.R. 1993. Soil Sampling and Methods of Analysis, Canadian Society of Soil Science, Lewis Publishers-CRC Press, Inc., Boca Raton, Florida.

Hareland, W., R. L. Crawford, P. J. Chapman, and S. Dagley. 1975. Òmetabolic Function and Properties of 4-Hydroxyphenylacetic Acid 1-Hydroxylase from Pseudomonas Acidovorans. Ó J. Bacteriol., 121:272.

Korte, N. E., P. M. Kearl, H. L. Fleischhauer, and J. M. Sewell. 1985. Hydrogeologic Characterization of the Department of Energy Kansas City Facility: Interim Report. GJ-31. Bendix Field Engineering Corp. Grand Junction, Colorado.

Shields, M. S., S. O. Montgomery, S. M. Cuskey, P. J. Chapman, and P. H. Pritchard. 1991. Òmutants of Pseudomonas cepacia G4 Defective in Catabolism of Aromatic Compounds and Trichloroethylene. Ó Applied Environ. Microbiol., 57:1935.

Shields, M. S. and M. J. Reagin. 1992. ÒSelection of a Pseudomonas cepacia Strain Constitutive for the Degradation of Trichloroethylene. Ó Applied Environ. Microbiol., 58:3977.

U.S. DOE. 1990. Northeast Area Groundwater Assessment Plan. U.S. Department of Energy, Kansas City Plant, Kansas City, Missouri.

U.S. DOE. 1994. Northeast Area/001 Outfall Corrective Measures Study. U.S. Department of Energy, Kansas City Plant, Kansas City, Missouri. 
West, O.R., P.A. Cameron, D.R. Smuin, N.E. Korte, and A.J. Lucero. 1995.

Innovative Treatment for TCE-Contaminated Saturated Cloy Soils in Emerging Technologies in Hazardous Waste Management VII Extended Abstracts presented for the Special Symposium, Atlanta, Georgia, Industrial and Engineering Chemistry Division, American Chemical Society. 
APPENDIX A

Pre-treatment Lithologic Borings 
Borehole Summary Information

OAK FIDEE NATIONAL LABORATORY

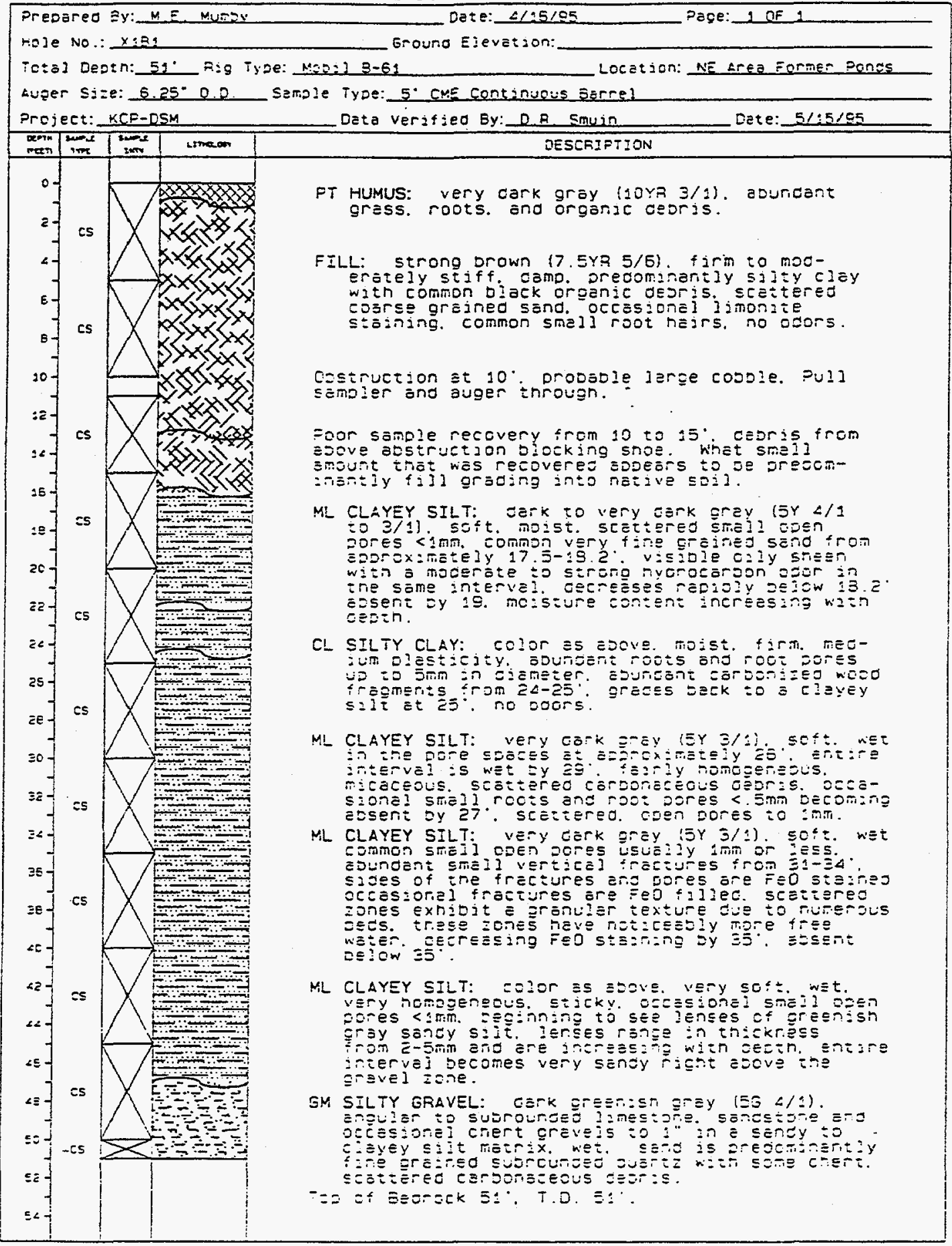


Borehole Summary Information

DII 1 OAK RIDGE national Laboratory

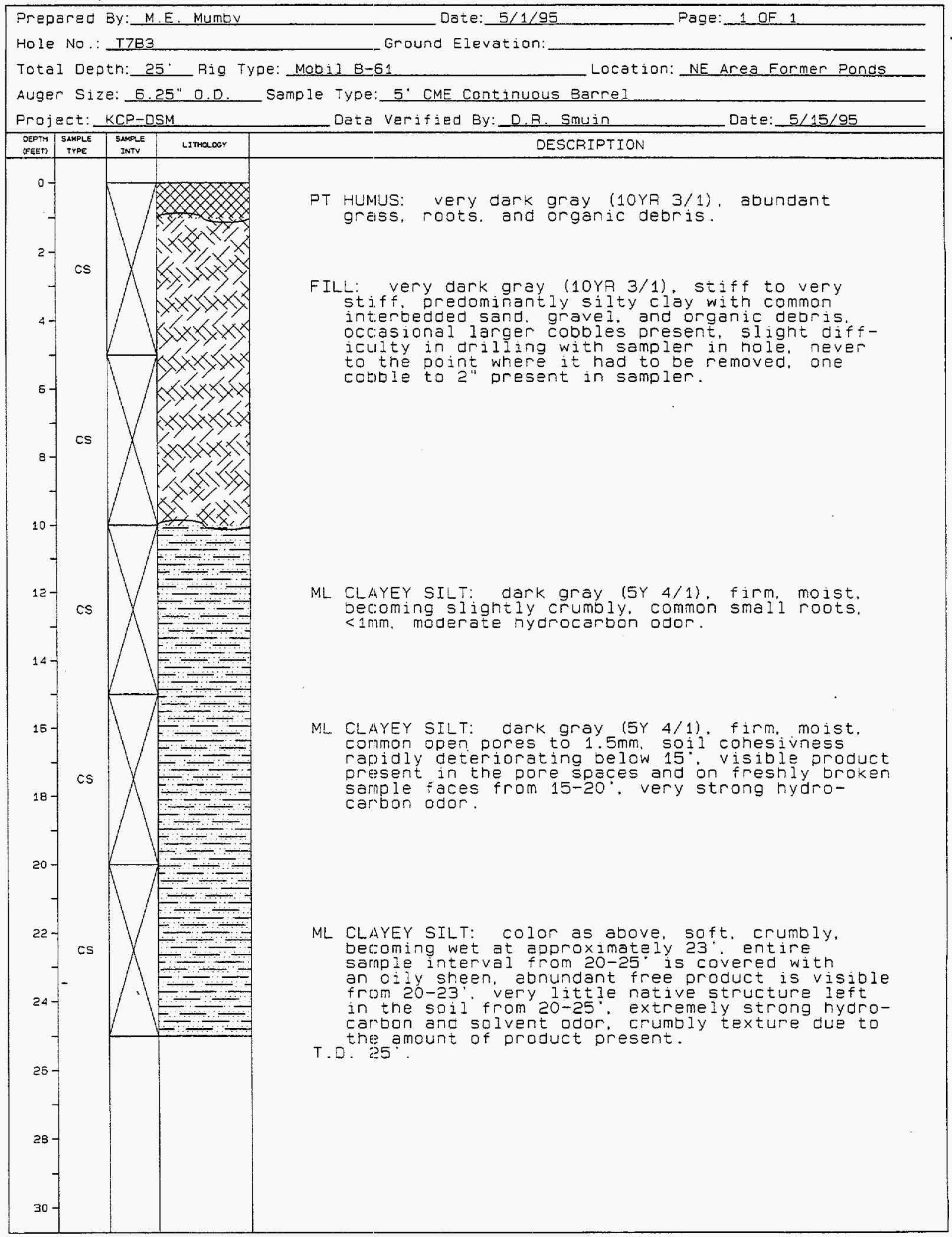




\section{$A-3$}

\section{orn 1}

Borehole Summary Information

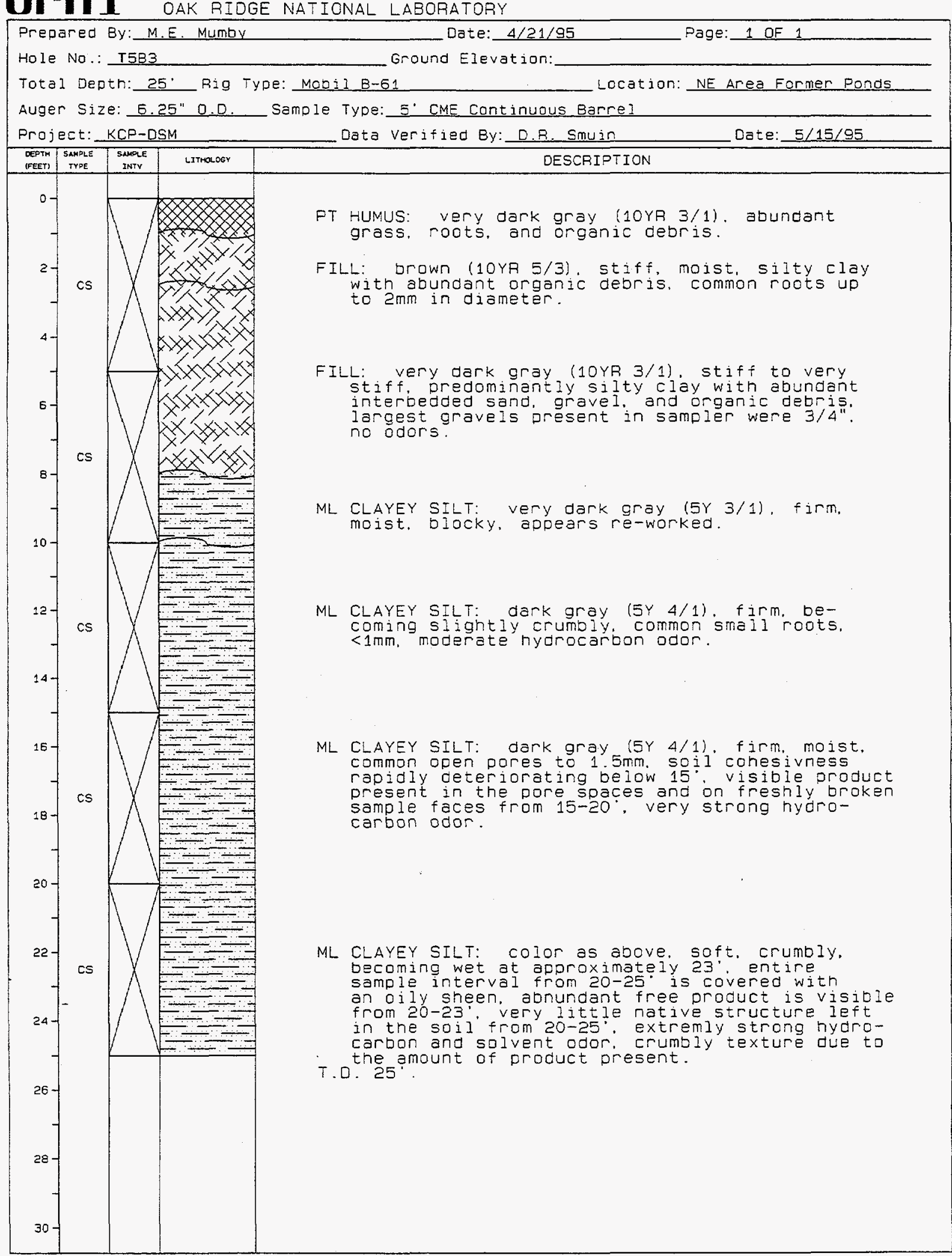


Borehole Summary Information

OII 1 oak rioge national Laboratory.

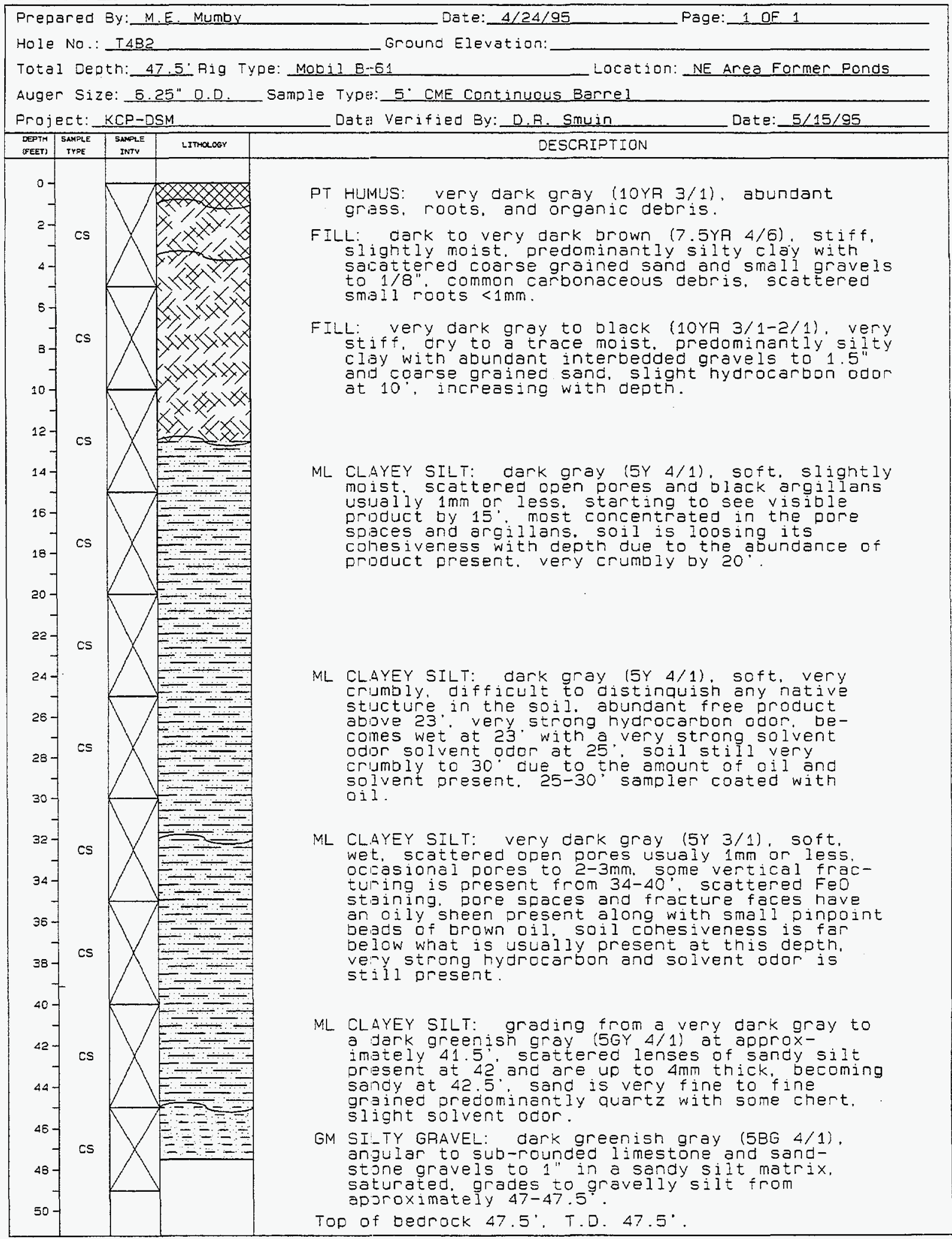


orn 1

Borehole Summary Information

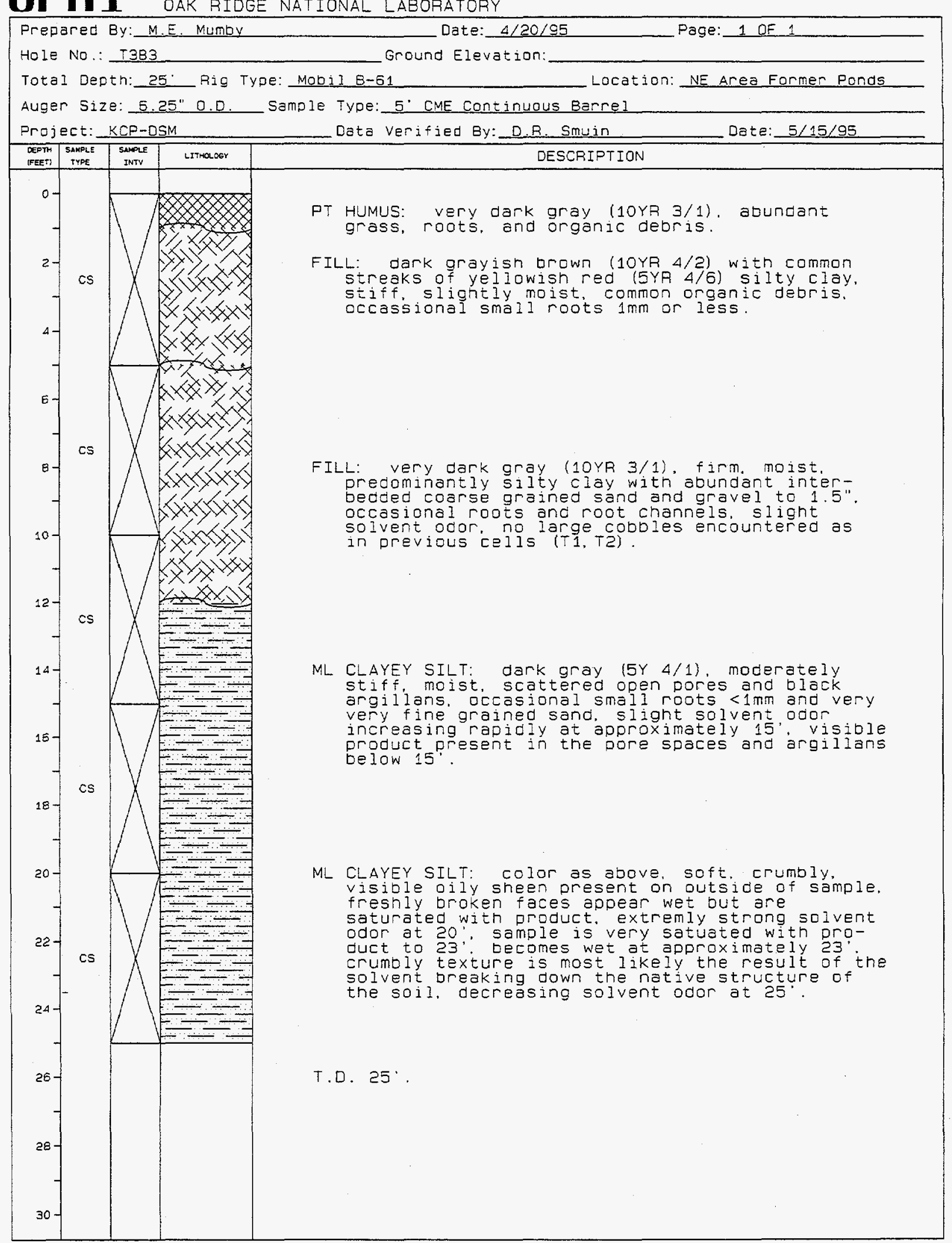


Borehole Summary Information

QII OAK RIDGE NATIONAL LABORATORY

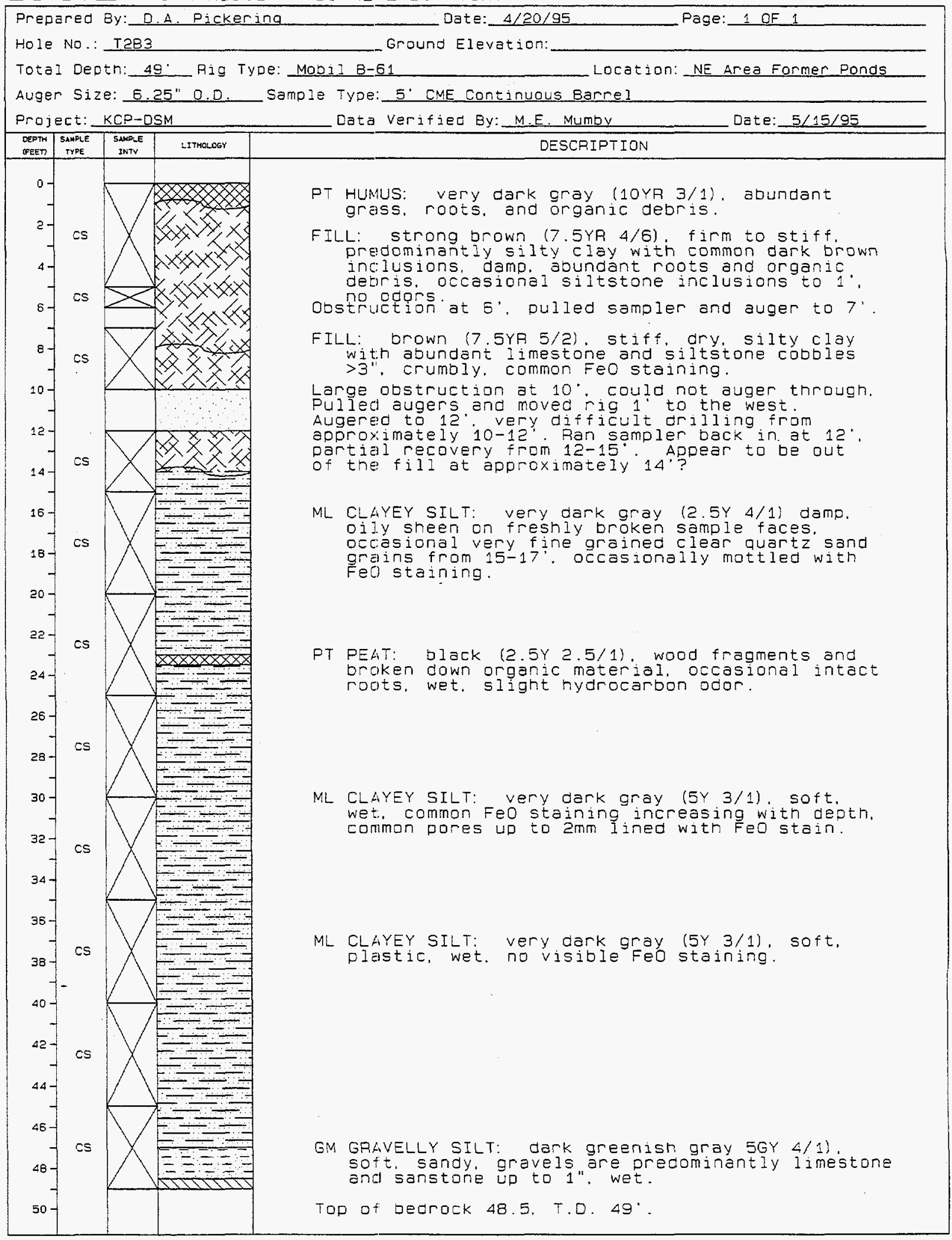




$$
A-7
$$

orn 1

Borehole Summary Information

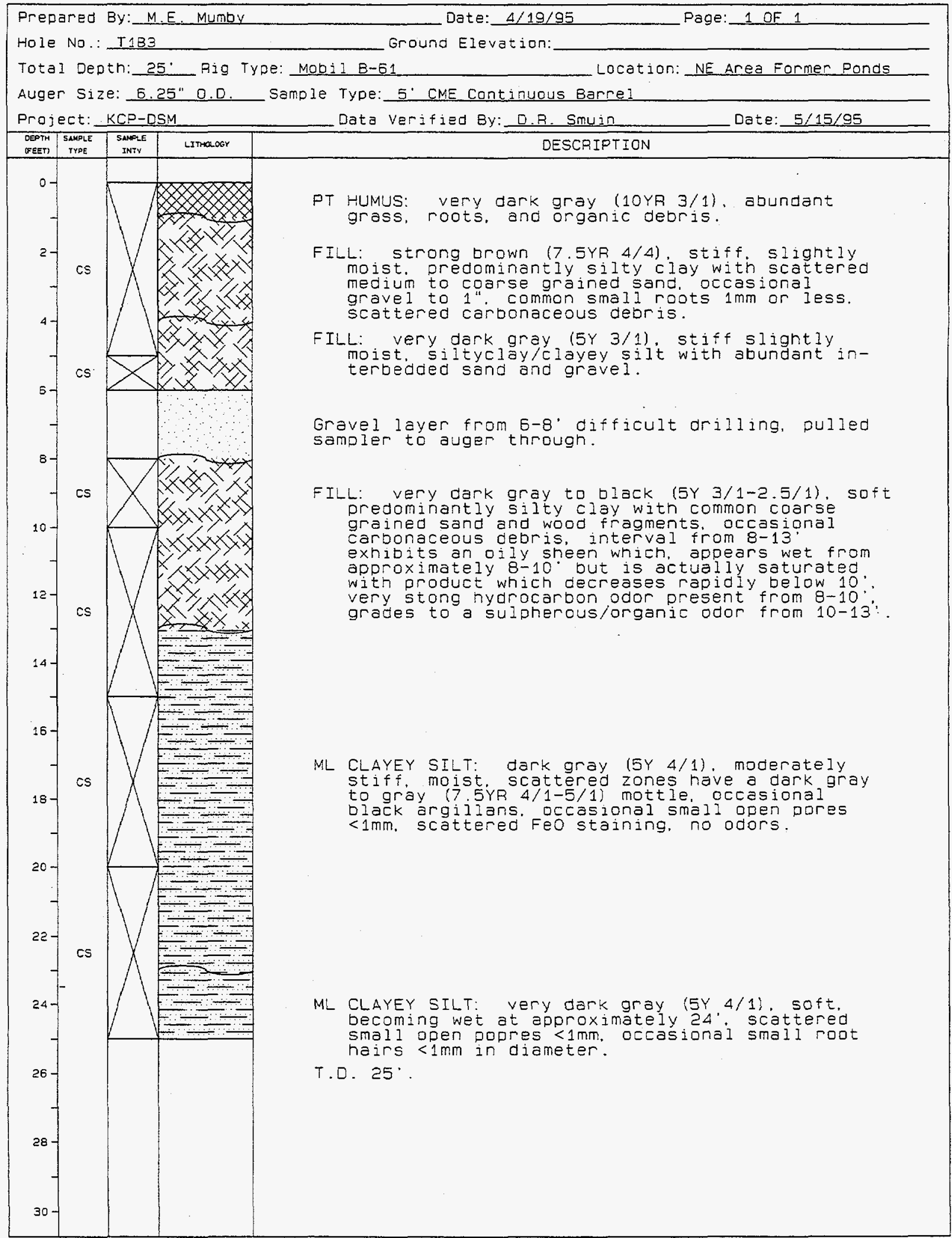




\section{APPENDIX B}

Kansas City Plant Deep Soil Mixing Demonstration Project

Pre-treatment cis-1,2-DCE and TCE Content in Soil, $\mu \mathrm{g} / \mathrm{kg}$ and Groundwater, $\mu \mathrm{g} / \mathrm{L}$ 


\section{APPENDIX B}

\section{Kansas City Plant Deep Soil Mixing Demonstration Project}

Pre-treatment cis-1,2-DCE and TCE Content in Soil, $\mu \mathrm{g} / \mathrm{kg}$ and Groundwater, $\mu \mathrm{g} / \mathrm{L}$

\section{Pre-Treatment samples from T1 Cell}

Pre-T1B1

\begin{tabular}{|c|c|c|c|c|c|c|c|}
\hline Sample & Depth & Weight, g & Dilution & $\begin{array}{l}\text { cis-DCE, } \\
\text { gross }\end{array}$ & $\begin{array}{l}\text { cis-DCE, } \\
\mu \mathrm{g} / \mathrm{kg}\end{array}$ & $\begin{array}{l}\text { TCE, } \\
\text { gross }\end{array}$ & $\begin{array}{l}\text { TCE, } \\
\mu \mathrm{g} / \mathrm{kg}\end{array}$ \\
\hline 050 & 01 & 4.96 & $1 \mathrm{x}$ & $<2000$ & $<2000$ & $<5.0$ & $<5.0$ \\
\hline 052 & 10 & 3.85 & $1 \mathrm{x}$ & 29,200 & 37,900 & $2 \mathrm{~J}$ & $2 \mathrm{~J}$ \\
\hline 054 & 11 & 5.74 & $1 \mathrm{x}$ & 22,800 & 19,850 & $2 J$ & $2 J$ \\
\hline 056 & 15 & 4.51 & $1 x$ & 3420 & 3800 & $2 \mathrm{~J}$ & $2 J$ \\
\hline 057 & 16 & 4.19 & $1 \mathrm{x}$ & 2990 & 3550 & $2 \mathrm{~J}$ & $2 \mathrm{~J}$ \\
\hline 058 & 19 & 5.04 & $1 \mathrm{x}$ & $<2000$ & $<2000$ & $<5.0$ & $<5.0$ \\
\hline 059 & 21 & 5.15 & $1 \mathrm{x}$ & $<2000$ & $<2000$ & $<5.0$ & $<5.0$ \\
\hline 060 & $21 \mathrm{D}$ & 5.33 & $1 x$ & $<2000$ & $<2000$ & $<5.0$ & $<5.0$ \\
\hline 061 & $25 W$ & $N A$ & $I x$ & 28,800 & $N A$ & $<5.0$ & NA \\
\hline \multicolumn{8}{|c|}{ Pre-T1B2 } \\
\hline Sample & Depth & Weight, g & Dilution & $\begin{array}{l}\text { cis-DCE, } \\
\text { gross }\end{array}$ & $\begin{array}{l}\text { cis-DCE, } \\
\mu \mathrm{g} / \mathrm{kg}\end{array}$ & $\begin{array}{l}\text { TCE, } \\
\text { gross }\end{array}$ & $\begin{array}{l}\text { TCE, } \\
\mu \mathrm{g} / \mathrm{kg}\end{array}$ \\
\hline 038 & 01 & 4.59 & $1 x$ & $<2000$ & $<2000$ & $2 \mathrm{~J}$ & $2 \mathrm{~J}$ \\
\hline 040 & 06 & 4.81 & $1 \mathrm{x}$ & 4950 & 5150 & $<5.0$ & $<5.0$ \\
\hline 042 & $06 \mathrm{D}$ & 3.88 & $1 x$ & 4110 & 5300 & $<5.0$ & $<5.0$ \\
\hline 043 & 11 & 5.90 & $1 x$ & $<2000$ & $<2000$ & $<5.0$ & $<5.0$ \\
\hline 045 & 16 & 4.96 & $1 x$ & $<2000$ & $<2000$ & $2 \mathrm{~J}$ & $2 \mathrm{~J}$ \\
\hline 047 & 21 & 5.20 & $1 x$ & $<2000$ & $<2000$ & $<5.0$ & $<5.0$ \\
\hline 049 & $25 W$ & $N A$ & $I x$ & 45,300 & $\mathrm{NA}$ & $2 J$ & $N A$ \\
\hline
\end{tabular}

B-1 
Pre-T1B3

\begin{tabular}{llllllll}
\hline Sample & Depth & Weight, g & Dilution & $\begin{array}{l}\text { cis-DCE, } \\
\text { gross }\end{array}$ & $\begin{array}{l}\text { cis-DCE, } \\
\mu \mathrm{g} / \mathbf{k g}\end{array}$ & $\begin{array}{l}\text { TCE, } \\
\text { gross }\end{array}$ & $\begin{array}{l}\text { TCE, } \\
\mu \mathrm{g} / \mathrm{kg}\end{array}$ \\
031 & 01 & 5.12 & $1 \mathrm{x}$ & $<2000$ & $<2000$ & $2 \mathrm{~J}$ & $2 \mathrm{~J}$ \\
032 & 06 & 4.31 & $1 \mathrm{x}$ & $<2000$ & $<2000$ & 42 & 48.5 \\
033 & 10 & 5.73 & $1 \mathrm{x}$ & $<2000$ & $<2000$ & $<5.0$ & $<5.0$ \\
034 & 11 & 3.95 & $1 \mathrm{x}$ & $<2000$ & $<2000$ & $<5.0$ & $<5.0$ \\
& & & & & & & \\
035 & 16 & 5.22 & $1 \mathrm{x}$ & $<2000$ & $<2000$ & $<5.0$ & $<5.0$ \\
036 & 21 & 4.59 & $1 \mathrm{x}$ & $<2000$ & $<2000$ & $<5.0$ & $<5.0$ \\
037 & 25 & 5.78 & $1 \mathrm{x}$ & $<2000$ & $<2000$ & $<5.0$ & $<5.0$
\end{tabular}

\section{Pre-T1B4}

$\begin{array}{llllllll}\text { Sample } & \text { Depth } & \text { Weight, g } & \text { Dilution } & \begin{array}{l}\text { cis-DCE, } \\ \text { gross }\end{array} & \begin{array}{l}\text { cis-DCE, } \\ \mu \mathrm{g} / \mathrm{kg}\end{array} & \begin{array}{l}\text { TCE, } \\ \text { gross }\end{array} & \begin{array}{l}\text { TCE, } \\ \mu \mathrm{g} / \mathrm{kg}\end{array} \\ 023 & 01 & 5.72 & 1 \mathrm{x} & <2000 & <2000 & <5.0 & <5.0 \\ 024 & 06 & 6.36 & 1 \mathrm{x} & <2000 & <2000 & 2 \mathrm{~J} & 2 \mathrm{~J} \\ 025 & 11 & 6.34 & 1 \mathrm{x} & <2000 & <2000 & <5.0 & <5.0 \\ 026 & 16 & 5.57 & 1 \mathrm{x} & <2000 & <2000 & <5.0 & <5.0 \\ & & & & & & & <5.0 \\ 027 & 21 & 5.89 & 1 \mathrm{x} & <2000 & <2000 & <5.0 & <5.0 \\ 028 & 21 \mathrm{D} & 5.06 & 1 \mathrm{x} & <2000 & <2000 & <5.0 & <5.0\end{array}$

Pre-T1B5

$\begin{array}{llllllll}\text { Sample } & \text { Depth } & \text { Weight, } \mathbf{g} & \text { Dilution } & \begin{array}{l}\text { cis-DCE, } \\ \text { gross }\end{array} & \begin{array}{l}c i s-D C E, \\ \mu \mathrm{g} / \mathbf{k g}\end{array} & \begin{array}{l}\text { TCE, } \\ \text { gross }\end{array} & \begin{array}{l}\text { TCE, } \\ \mu \mathrm{g} / \mathrm{kg}\end{array} \\ 018 & 01 & 5.19 & 1 \mathrm{x} & <2000 & <2000 & <5.0 & <5.0 \\ 019 & 06 & 5.31 & 1 \mathrm{x} & <2000 & <2000 & 2 \mathrm{~J} & 2 \mathrm{~J} \\ 020 & 11 & 7.22 & 1 \mathrm{x} & <2000 & <2000 & <5.0 & <5.0 \\ 021 & 16 & 6.17 & 1 \mathrm{x} & <2000 & <2000 & <5.0 & <5.0 \\ 022 & 21 & 4.81 & 1 \mathrm{x} & <2000 & <2000 & <5.0 & <5.0\end{array}$

D: soil sample duplicate

$\mathrm{J}$ : estimated concentration

NA: not applicable

W: groundwater sample (denoted by italics and shading) 
B-3

Pre-treatment samples from T2 Cell

Pre-T2B1

\begin{tabular}{|c|c|c|c|c|c|c|c|}
\hline Sample & Depth & Weight, g & Dilution & $\begin{array}{l}\text { cis-DCE, } \\
\text { gross }\end{array}$ & $\begin{array}{l}\text { cis-DCE, } \\
\mu \mathrm{g} / \mathrm{kg}\end{array}$ & $\begin{array}{l}\text { TCM, } \\
\text { gross }\end{array}$ & $\begin{array}{c}\text { TCE, } \\
\mu \mathrm{g} / \mathrm{kg}\end{array}$ \\
\hline 164 & 01 & 5.14 & $1 x$ & $<2000$ & $<2000$ & 2.6 & 1.0 \\
\hline 165 & 11 & 6.32 & $100 x$ & 52,000 & 41,150 & 50,040 & 39,600 \\
\hline 166 & 16 & 6.19 & $100 x$ & $<2000$ & $<2000$ & 3890 & 2640 \\
\hline 167 & 21 & 5.51 & $1 \mathrm{x}$ & $<2000$ & $<2000$ & $<5.0$ & $<5.0$ \\
\hline 168 & 26 & 5.41 & $1 x$ & $<2000$ & $<2000$ & $<5.0$ & $<5.0$ \\
\hline 171 & 31 & 6.31 & $1 \mathrm{x}$ & $<2000$ & $<2000$ & $<5.0$ & $<5.0$ \\
\hline 172 & 36 & 5.69 & $1 x$ & $<2000$ & $<2000$ & $<5.0$ & $<5.0$ \\
\hline 174 & 41 & 5.26 & $1 x$ & $<2000$ & $<2000$ & 37 & 35 \\
\hline 175 & 46 & 4.66 & $1 x$ & $<2000$ & $<2000$ & $<5.0$ & $<5.0$ \\
\hline 169 & $30 W$ & $N A$ & $1 x$ & $<2000$ & $N A$ & 212 & $N A$ \\
\hline 170 & $30 W D$ & $N A$ & $I x$ & $<2000$ & $N A$ & 236 & $N A$ \\
\hline 173 & $40 W$ & $N A$ & $1 x$ & $<2000$ & $N A$ & 877 & $N A$ \\
\hline 176 & $50 W$ & $N A$ & $7 x$ & $<2000$ & $N A$ & 622 & $N A$ \\
\hline
\end{tabular}

Pre-T2B2

\begin{tabular}{|c|c|c|c|c|c|c|c|}
\hline Sample & Depth & Weight, g & Dilution & $\begin{array}{l}\text { cis-DCE, } \\
\text { gross }\end{array}$ & $\begin{array}{l}c i s-D C E \\
\mu \mathrm{g} / \mathrm{kg}\end{array}$ & $\begin{array}{l}\text { TCE, } \\
\text { gross }\end{array}$ & $\begin{array}{c}\text { TCE, } \\
\mu \mathrm{g} / \mathrm{kg}\end{array}$ \\
\hline 149 & 01 & 4.03 & $1 x$ & $<2000$ & $<2000$ & $2 \mathrm{~J}$ & $2 J$ \\
\hline 150 & 11 & 5.41 & $10 x$ & 52,000 & 48,050 & 8420 & 7800 \\
\hline 151 & 16 & 6.40 & $100 x$ & $<2000$ & $<2000$ & 13,150 & 10,250 \\
\hline 152 & 21 & 5.75 & $1 x$ & $<2000$ & $<2000$ & $<5.0$ & $<5.0$ \\
\hline 153 & 26 & 2.21 & $1 x$ & $<2000$ & $<2000$ & $<5.0$ & $<5.0$ \\
\hline 155 & 31 & 6.06 & $1 x$ & $<2000$ & $<2000$ & $<5.0$ & $<5.0$ \\
\hline 156 & 36 & 6.27 & $1 x$ & $<2000$ & $<2000$ & $<5.0$ & $<5.0$ \\
\hline 159 & 41 & 6.00 & $1 x$ & $<2000$ & $<2000$ & 176 & 147 \\
\hline 160 & $41 D$ & 5.28 & $1 x$ & $<2000$ & $<2000$ & $2 \mathrm{~J}$ & $2 \mathrm{~J}$ \\
\hline 161 & 46 & 4.88 & $1 x$ & $<2000$ & $<2000$ & $<5.0$ & $<5.0$ \\
\hline 162 & 49 & 5.83 & Ix & $<2000$ & $<2000$ & $<5.0$ & $<5.0$ \\
\hline 154 & $30 W$ & $N A$ & $1 x$ & $<2000$ & $N A$ & 178 & $N A$ \\
\hline 158 & $40 W$ & $N A$ & $I x$ & $<2000$ & $N A$ & 632 & $N A$ \\
\hline 163 & $49 W$ & $N A$ & $1 x$ & $<2000$ & $N A$ & 433 & $N A$ \\
\hline
\end{tabular}


Pre-T2B3

\begin{tabular}{|c|c|c|c|c|c|c|c|}
\hline Sample & Depth & Weight, g & Dilution & $\begin{array}{l}\text { cis-DCE, } \\
\text { gross }\end{array}$ & $\begin{array}{l}\text { cis-DCE, } \\
\mu \mathrm{g} / \mathrm{kg}\end{array}$ & $\begin{array}{l}\text { TCE, } \\
\text { gross }\end{array}$ & $\begin{array}{l}\text { TCE, } \\
\mu \mathrm{g} / \mathrm{kg}\end{array}$ \\
\hline 062 & 01 & $5: 57$ & $1 x$ & $<2000$ & $<2000$ & $2 \mathrm{~J}$ & $2 \mathrm{~J}$ \\
\hline 063 & 08 & 27 & $1 x$ & 27,110 & 18,650 & 530 & 365 \\
\hline 064 & 13 & 5.97 & $1 x$ & 44,340 & 37,150 & 20,820 & 17,450 \\
\hline 065 & 16 & 5.87 & $1 x$ & 16,900 & 14,400 & 25,740 & 21,950 \\
\hline 066 & 21 & 4.67 & $1 x$ & $<2000$ & $<2000$ & $<5.0$ & $<5.0$ \\
\hline 067 & 26 & 5.97 & $1 x$ & $<2000$ & $<2000$ & $<5.0$ & $<5.0$ \\
\hline 069 & 31 & 4.27 & $1 x$ & $<2000$ & $<2000$ & $1.5 \mathrm{~J}$ & $2 \mathrm{~J}$ \\
\hline 070 & 36 & 4.27 & $1 x$ & $<2000$ & $<2000$ & $<5.0$ & $<5.0$ \\
\hline 072 & 41 & 4.82 & $1 x$ & $<2000$ & $<2000$ & $<5.0$ & $<5.0$ \\
\hline 073 & 46 & 5.28 & $1 x$ & $<2000$ & $<2000$ & $<5.0$ & $<5.0$ \\
\hline 074 & $46 \mathrm{D}$ & 5.39 & $1 x$ & $<2000$ & $<2000$ & $<5.0$ & $<5.0$ \\
\hline 075 & 49 & 5.54 & $1 x$ & $<2000$ & $<2000$ & $<5.0$ & $<5.0$ \\
\hline 068 & $30 \mathrm{~W}$ & $N A$ & $1 x$ & 39,890 & $N A$ & 118 & $N A$ \\
\hline 071 & $40 W$ & $N A$ & $I x$ & 18,400 & $N A$ & 102 & $N A$ \\
\hline 076 & $49 W$ & $N A$ & $I x$ & 15,580 & $N A$ & 150 & $N A$ \\
\hline
\end{tabular}

Pre-T2B4

$\begin{array}{llllllll}\text { Sample } & \text { Depth } & \text { Weight, } & \text { Dilution } & \begin{array}{l}\text { cis-DCE, } \\ \text { gross }\end{array} & \begin{array}{l}\text { cis-DCE, } \\ \mu \text { g/kg }\end{array} & \begin{array}{l}\text { TCE, } \\ \text { gross }\end{array} & \begin{array}{l}\text { TCE, } \\ \mu \mathrm{g} / \mathbf{k g}\end{array} \\ & & & & & & & \\ 133 & 01 & 5.83 & 1 \mathrm{x} & <2000 & <2000 & 20 & 17 \\ 134 & 06 & 5.14 & 1 \mathrm{x} & 8879 & 8650 & 132 & 129 \\ 135 & 10 & 4.11 & 10 \mathrm{x} & 190,600 & 231,850 & 3760 & 4575 \\ 136 & 11 & 5.77 & 1 \mathrm{x} & 87,920 & 76,200 & 120 & 104 \\ & & & & & & & \\ 137 & 16 & 6.65 & 100 \mathrm{x} & <2000 & <2000 & 35,550 & 26,750 \\ 138 & 21 & 4.20 & 1 \mathrm{x} & <2000 & <2000 & <5.0 & <5.0 \\ 139 & 26 & 4.94 & 1 \mathrm{x} & <2000 & <2000 & <5.0 & <5.0 \\ 141 & 31 & 3.39 & 1 \mathrm{x} & <2000 & <2000 & <5.0 & <5.0 \\ & & & & & & & \\ 142 & 36 & 4.78 & 1 \mathrm{x} & <2000 & <2000 & <5.0 & <5.0 \\ 144 & 41 & 4.45 & 1 \mathrm{x} & <2000 & <2000 & <5.0 & <5.0 \\ 145 & 41 \mathrm{D} & 5.48 & 1 \mathrm{x} & <2000 & <2000 & <5.0 & <5.0 \\ 146 & 46 & 5.36 & 1 \mathrm{x} & <2000 & <2000 & <5.0 & <5.0 \\ 147 & 49 & 4.89 & 1 \mathrm{x} & <2000 & <2000 & <5.0 & <5.0 \\ & & & & & & & \\ 140 & 30 W & N A & 1 x & 4280 & N A & 254 & N A \\ 143 & 40 W & N A & 1 x & 19,980 & N A & 869 & N A \\ 148 & 49 W & N A & 1 x & 7850 & N A & 516 & N A\end{array}$


B-5

Pre-T2B5

\begin{tabular}{llllllll}
\hline Sample & Depth & Weight, g & Dilution & $\begin{array}{l}\text { cis-DCE, } \\
\text { gross }\end{array}$ & $\begin{array}{l}c i s-D C E, \\
\mu \text { g/kg }\end{array}$ & $\begin{array}{l}\text { TCE, } \\
\text { gross }\end{array}$ & $\begin{array}{l}\text { TCE, } \\
\mu \text { g/kg }\end{array}$ \\
114 & 01 & 6.40 & $1 \mathrm{x}$ & $<2000$ & $<2000$ & $2 \mathrm{~J}$ & $2 \mathrm{~J}$ \\
115 & 06 & 5.64 & $10 \mathrm{x}$ & $<2000$ & $<2000$ & 191 & 170 \\
116 & 09 & 3.88 & $100 \mathrm{x}$ & 433,000 & 558,000 & 103,200 & 133,000 \\
117 & 11 & 4.09 & $100 \mathrm{x}$ & 67,530 & 82,500 & 685 & 840 \\
& & & & & & & \\
118 & 16 & 6.79 & $100 \mathrm{x}$ & $<2000$ & $<2000$ & 37,000 & 27,250 \\
119 & 20 & 4.51 & $100 \mathrm{x}$ & $<2000$ & $<2000$ & 64 & 70 \\
120 & 21 & 3.81 & $100 \mathrm{x}$ & $<2000$ & $<2000$ & $<5.0$ & $<5.0$ \\
121 & $21 \mathrm{D}$ & 4.34 & $100 \mathrm{x}$ & $<2000$ & $<2000$ & 33 & 40 \\
& & & & & & & \\
123 & 26 & 5.63 & $1 \mathrm{x}$ & $<2000$ & $<2000$ & $<5.0$ & $<5.0$ \\
124 & 31 & 5.88 & $10 \mathrm{x}$ & $<2000$ & $<2000$ & $<5.0$ & $<5.0$ \\
126 & 36 & 6.28 & $10 \mathrm{x}$ & $<2000$ & $<2000$ & $<5.0$ & $<5.0$ \\
128 & 41 & 5.25 & $100 \mathrm{x}$ & $<2000$ & $<2000$ & $<5.0$ & $<5.0$ \\
129 & 46 & 4.97 & $1 \mathrm{x}$ & $<2000$ & $<2000$ & $<5.0$ & $<5.0$ \\
130 & $46 \mathrm{D}$ & 5.63 & $1 \mathrm{x}$ & $<2000$ & $<2000$ & $<5.0$ & $<5.0$ \\
& & & & & & & \\
122 & $25 W$ & $N A$ & $1 \times$ & 19,310 & $N A$ & 1470 & $N A$ \\
127 & $40 W$ & $N A$ & $1 x$ & 25,060 & $N A$ & 2220 & $N A$ \\
131 & $50 W$ & $N A$ & $10 x$ & 20,440 & $N A$ & 1280 & $N A$ \\
\hline
\end{tabular}

D: soil sample duplicate $\mathrm{J}$ : estimated concentration NA: not applicable W: groundwater sample (denoted by italics and shading) WD: groundwater sample duplicate 
Pre-treatment samples from T3 Cell

Pre-T3B1

\begin{tabular}{|c|c|c|c|c|c|c|c|}
\hline Sample & Depth & Weight, $g$ & Dilution & $\begin{array}{l}\text { cis-DCE, } \\
\text { gross }\end{array}$ & $\begin{array}{l}\text { cis-DCE, } \\
\mu \mathrm{g} / \mathrm{kg}\end{array}$ & $\begin{array}{l}\text { TCE, } \\
\text { gross }\end{array}$ & $\begin{array}{l}\text { TCE, } \\
\mu \mathbf{g} / \mathbf{k g}\end{array}$ \\
\hline 281 & 01 & 6.25 & $1 \mathrm{x}$ & $<2000$ & $<2000$ & 150 & 120 \\
\hline 282 & 06 & 6.36 & $100 x$ & $<2000$ & $<2000$ & 57,500 & 45,200 \\
\hline 283 & $06 \mathrm{D}$ & 5.85 & $100 x$ & $<2000$ & $<2000$ & 16,830 & 14,400 \\
\hline 284 & 11 & 5.30 & $100 x$ & $<2000$ & $<2000$ & 9090 & 8600 \\
\hline 285 & 16 & 5.64 & $1 x$ & 25,300 & 22,430 & $1 \mathrm{~J}$ & $1 \mathrm{~J}$ \\
\hline 286 & 21 & 5.55 & $1 x$ & 65,570 & 59,070 & 101 & 91 \\
\hline 287 & 25 & 5.82 & $1 x$ & $<2000$ & $<2000$ & 164 & 141 \\
\hline 288 & $25 W$ & $N A$ & $1 x$ & $<2000$ & $N A$ & 533 & $N A$ \\
\hline
\end{tabular}

Pre-T3B2

\begin{tabular}{|c|c|c|c|c|c|c|c|}
\hline Sample & Depth & Weight, $g$ & Dilution & $\begin{array}{l}\text { cis-DCE, } \\
\text { gross }\end{array}$ & $\begin{array}{l}\text { cis-DCE, } \\
\mu \mathrm{g} / \mathbf{k g}\end{array}$ & $\begin{array}{l}\text { TCE, } \\
\text { gross }\end{array}$ & $\begin{array}{l}\text { TCE, } \\
\mu \mathrm{g} / \mathrm{kg}\end{array}$ \\
\hline 272 & 01 & 4.78 & $1 x$ & $<2000$ & $<2000$ & 34 & 35 \\
\hline 273 & 06 & 5.32 & $10 x$ & $<2000$ & $<2000$ & 2640 & 2480 \\
\hline 275 & 11 & 6.48 & $10 x$ & $<2000$ & $<2000$ & 8700 & 6700 \\
\hline 276 & 16 & 5.19 & $100 x$ & $<2000$ & $<2000$ & 82,310 & 79,300 \\
\hline 277 & 21 & 5.24 & $1000 x$ & $<2000$ & $<2000$ & 209,900 & 200,300 \\
\hline 278 & 25 & 6.15 & $10 x$ & $<2000$ & $<2000$ & 891 & 725 \\
\hline 279 & $25 \mathrm{~W}$ & $N A$ & $10 x$ & $\$ 20000$ & $N A$ & 6780 & $N A$ \\
\hline
\end{tabular}

Pre-T3B3

$\begin{array}{llllllll}\text { Sample } & \text { Depth } & \text { Weight, g } & \text { Dilution } & \begin{array}{l}\text { cis-DCE, } \\ \text { gross }\end{array} & \begin{array}{l}\text { cis-DCE, } \\ \mu \text { g/kg }\end{array} & \begin{array}{l}\text { TCE, } \\ \text { gross }\end{array} & \begin{array}{l}\text { TCE, } \\ \mu \text { g/kg }\end{array} \\ 077 & 03 & 5.80 & 1 \times & <2000 & <2000 & 31 & 27 \\ 078 & 07 & 6.03 & 1 \times & <2000 & <2000 & 252 & 210 \\ 079 & 05 & 3.85 & 100 \times & 4280 & 5550 & 40,380 & 52,450 \\ 080 & 11 & 5.91 & 1 \times & 2210 & 1870 & 686 & 580 \\ 081 & 20 & 5.65 & 1000 \times & <2000 & <2000 & 579,400 & 512,500 \\ 082 & 16 & 5.97 & 1000 \mathrm{x} & <2000 & <2000 & 202,400 & 169,500 \\ 083 & 21 & 5.19 & 1000 \mathrm{x} & <2000 & <2000 & 299,700 & 288,750 \\ & & & & & & & \\ 084 & 25 W & N A & 100 x & <2000 & N A & 10,180 & N A\end{array}$


B-7

Pre-T3B4

\begin{tabular}{|c|c|c|c|c|c|c|c|}
\hline Sample & Depth & Weight, g & Dilution & $\begin{array}{l}\text { cis-DCE, } \\
\text { gross }\end{array}$ & $\begin{array}{l}\text { cis-DCE, } \\
\mu \mathrm{g} / \mathrm{kg}\end{array}$ & $\begin{array}{l}\text { TCE, } \\
\text { gross }\end{array}$ & $\begin{array}{l}\text { TCE, } \\
\mu \mathrm{g} / \mathbf{k g}\end{array}$ \\
\hline 260 & 01 & 6.08 & $1 x$ & $<2000$ & $<2000$ & $<5.0$ & $<5.0$ \\
\hline 261 & 06 & 5.92 & $1 x$ & $<2000$ & $<2000$ & 5.3 & $2 \mathrm{~J}$ \\
\hline 262 & 11 & 5.96 & $1 x$ & $<2000$ & $<2000$ & $2 J$ & $2 \mathrm{~J}$ \\
\hline 263 & 16 & 5.47 & $100 x$ & $<2000$ & $<2000$ & 41,550 & 38,000 \\
\hline 264 & $16 \mathrm{D}$ & 5.32 & $100 x$ & $<2000$ & $<2000$ & 60,170 & 56,550 \\
\hline 265 & 21 & 5.55 & $1000 x$ & $<2000$ & $<2000$ & 141,700 & 127,650 \\
\hline 266 & 25 & 4.45 & $1000 x$ & $<2000$ & $<2000$ & 322,000 & 361,800 \\
\hline 268 & 26 & 5.72 & $1000 x$ & $<2000$ & $<2000$ & 603,600 & 527,500 \\
\hline 267 & $25 \mathrm{~W}$ & $N 4$ & $10000 x$ & $<2000$ & $N A$ & 3,1600000 & $N A$ \\
\hline
\end{tabular}

\section{Pre-T3B5}

\begin{tabular}{|c|c|c|c|c|c|c|c|}
\hline Sample & Depth & Weight, g & Dilution & $\begin{array}{l}\text { cis-DCE, } \\
\text { gross }\end{array}$ & $\begin{array}{l}\text { cis-DCE, } \\
\mu \mathrm{g} / \mathrm{kg}\end{array}$ & $\begin{array}{l}\text { TCE, } \\
\text { gross }\end{array}$ & $\begin{array}{l}\text { TCE, } \\
\mu \mathrm{g} / \mathrm{kg}\end{array}$ \\
\hline 253 & 01 & 5.64 & $1 x$ & $<2000$ & $<2000$ & $<5.0^{\circ}$ & $<5.0$ \\
\hline 254 & 06 & 5.03 & $1 x$ & $<2000$ & $<2000$ & $<5.0$ & $<5.0$ \\
\hline 255 & 11 & 5.96 & $1 x$ & $<2000$ & $<2000$ & $<5.0$ & $<5.0$ \\
\hline 256 & 16 & 5.80 & $1000 x$ & $<2000$ & $<2000$ & 181,200 & 156,200 \\
\hline 257 & 21 & 5.03 & $1000 x$ & $<2000$ & $<2000$ & 263,320 & 261,750 \\
\hline 258 & 25 & 4.61 & $100 x$ & $<2000$ & $<2000$ & 58,890 & 63,850 \\
\hline 259 & $25 W$ & $N A$ & $1000 x$ & $<2000$ & $N A$ & 683,100 & $N A$ \\
\hline
\end{tabular}

D: soil sample duplicate

J: estimated concentration

NA: not applicable

W: groundwater sample (denoted by italics and shading) 
B-8

Pre-treatment samples from T4 Cell

Pre-T4B1

\begin{tabular}{|c|c|c|c|c|c|c|c|}
\hline Sample & Depth & Weight, g & Dilution & $\begin{array}{l}\text { cis-DCE, } \\
\text { gross }\end{array}$ & $\begin{array}{l}\text { cis-DCE, } \\
\mu \mathrm{g} / \mathrm{kg}\end{array}$ & $\begin{array}{l}\text { TCE, } \\
\text { gross }\end{array}$ & $\begin{array}{l}\text { TCE, } \\
\mu \mathrm{g} / \mathrm{kg}\end{array}$ \\
\hline 235 & 01 & 5.52 & $1 x$ & $<2000$ & $<2000$ & $<5.0$ & $<5.0$ \\
\hline 236 & 06 & 6.04 & $1 x$ & $<2000$ & $<2000$ & $2 \mathrm{~J}$ & $2 \mathrm{~J}$ \\
\hline 237 & 11 & 5.40 & $1 x$ & $<2000$ & $<2000$ & $<5.0$ & $<5.0$ \\
\hline 238 & $11 \mathrm{D}$ & 4.30 & $1 x$ & $<2000$ & $<2000$ & $<5.0$ & $<5.0$ \\
\hline 239 & 15 & 6.22 & $1000 x$ & $<2000$ & $<2000$ & 213,400 & 171,500 \\
\hline 240 & 16 & 6.36 & $1000 x$ & $<2000$ & $<2000$ & 118,350 & 93,050 \\
\hline 241 & 20 & 6.19 & $1000 x$ & $<2000$ & $<2000$ & 655,700 & 529,500 \\
\hline 242 & 21 & 5.71 & $1000 x$ & $<2000$ & $<2000$ & $1,331,000$ & $1,165,500$ \\
\hline 243 & 26 & 6.12 & $100 x$ & $<2000$ & $<2000$ & 42,130 & 34,400 \\
\hline 245 & 31 & 5.87 & $100 x$ & $<2000$ & $<2000$ & 65,000 & 55,350 \\
\hline 246 & 33 & 5.90 & $100 x$ & $<2000$ & $<2000$ & 53,020 & 44,950 \\
\hline 247 & 36 & 4.58 & $100 x$ & $<2000$ & $<2000$ & 61,290 & 66,900 \\
\hline 249 & 41 & 4.30 & $1000 x$ & $<2000$ & $<2000$ & 98,700 & 114,750 \\
\hline 250 & 46 & 5.44 & $1 x$ & $<2000$ & $<2000$ & 13,390 & 12,300 \\
\hline 251 & $46 \mathrm{D}$ & 5.63 & $1 x$ & $<2000$ & $<2000$ & 26,320 & 23,350 \\
\hline 244 & $30 W$ & $N A$ & $1000 x$ & $<2000$ & $N A$ & 384,600 & $N A$ \\
\hline 248 & $40 W$ & $N A$ & $1000 x$ & $<2000$ & $N A$ & 562,500 & $\mathrm{NA}$ \\
\hline 252 & $47 W$ & NA & $1000 x$ & $<2000$ & $N A$ & 250,700 & $N A$ \\
\hline
\end{tabular}

Pre-T4B2

\begin{tabular}{|c|c|c|c|c|c|c|c|}
\hline Sample & Depth & Weight, $\mathrm{g}$ & Dilution & $\begin{array}{l}\text { cis-DCE, } \\
\text { gross }\end{array}$ & $\begin{array}{c}\text { cis-DCE, } \\
\mu \mathrm{g} / \mathrm{kg}\end{array}$ & $\begin{array}{l}\text { TCE, } \\
\text { gross }\end{array}$ & $\begin{array}{l}\text { TCE, } \\
\mu \mathrm{g} / \mathrm{kg}\end{array}$ \\
\hline 217 & 01 & 5.37 & $1 x$ & $<2000$ & $<2000$ & 691 & 645 \\
\hline 218 & 06 & 6.38 & $1 x$ & $<2000$ & $<2000$ & $<5.0$ & $<5.0$ \\
\hline 219 & 11 & 6.40 & $1 x$ & 6850 & 5350 & $2 \mathrm{~J}$ & $2 \mathrm{~J}$ \\
\hline 220 & 15 & 4.88 & $1000 x$ & $<2000$ & $<2000$ & 285,500 & 292,500 \\
\hline 221 & 16 & 5.69 & $1000 x$ & $<2000$ & $<2000$ & 49,470 & 43,470 \\
\hline 222 & $16 \mathrm{D}$ & 5.27 & $1000 x$ & $<2000$ & $<2000$ & 61,160 & 58,000 \\
\hline 223 & 21 & 5.51 & $1000 x$ & $<2000$ & $<2000$ & 142,450 & 129,250 \\
\hline 224 & 26 & 6.03 & $1000 x$ & $<2000$ & $<2000$ & 276,200 & 229,000 \\
\hline 227 & 31 & 5.67 & $1000 x$ & $<2000$ & $<2000$ & 208,600 & 183,950 \\
\hline 228 & 36 & 4.26 & $100 x$ & $<200$ & $<200$ & 23,990 & 28,158 \\
\hline 230 & 41 & 5.23 & $1 x$ & 7530 & 7200 & 1160 & 1110 \\
\hline 231 & 46 & 5.50 & $100 x$ & $<2000$ & $<2000$ & 52,780 & 48,000 \\
\hline 232 & 47 & 4.86 & $1 x$ & $<2000$ & $<2000$ & 1170 & 1200 \\
\hline 226 & $30 W$ & $N A$ & $10,000 x$ & $<2000$ & $N A$ & $1,600,000$ & $N A$ \\
\hline 229 & $40 W$ & $N A$ & $1000 x$ & $\checkmark 2000$ & $N A$ & $1,202,000$ & $N A$ \\
\hline 233 & $475 W$ & $N A$ & $1000 x$ & $<2000$ & $N A$ & 563,600 & $N A$ \\
\hline 234 & $475 W D$ & $N A$ & $1000 x$ & $<2000$ & $N A$ & 527,800 & $N A$ \\
\hline
\end{tabular}


Pre-T4B3

\begin{tabular}{|c|c|c|c|c|c|c|c|}
\hline Sample & Depth & Weight, g & Dilution & $\begin{array}{l}\text { cis-DCE, } \\
\text { gross }\end{array}$ & $\begin{array}{l}c i s-D C E, \\
\mu \mathrm{g} / \mathrm{kg}\end{array}$ & $\begin{array}{l}\text { TCE, } \\
\text { gross }\end{array}$ & $\begin{array}{l}\text { TCE, } \\
\mu \mathrm{g} / \mathrm{kg}\end{array}$ \\
\hline 085 & 01 & 5.76 & $1 x$ & $<2000$ & $<2000$ & $<5.0$ & $<5.0$ \\
\hline 086 & 07 & 4.69 & $1 x$ & $<2000$ & $<2000$ & $2 J$ & $2 \mathrm{~J}$ \\
\hline 087 & 07D & 5.25 & $1 x$ & $<2000$ & $<2000$ & $2 \mathrm{~J}$ & $2 \mathrm{~J}$ \\
\hline 088 & 11 & 7.12 & $1 \mathrm{x}$ & 6940 & 4875 & 7.0 & 5.0 \\
\hline 089 & 15 & 5.68 & $1000 \mathrm{x}$ & $<2000$ & $<2000$ & 628,200 & 553,000 \\
\hline 090 & 16 & 5.18 & $1000 x$ & $<2000$ & $<2000$ & 827,200 & 798,500 \\
\hline 091 & 20 & 5.08 & $1000 x$ & $<2000$ & $<2000$ & 674,900 & 664,500 \\
\hline 092 & 21 & 4.83 & $1000 x$ & $<2000$ & $<2000$ & 920,300 & 952,500 \\
\hline 093 & 22 & 3.52 & $1000 x$ & $<2000$ & $<2000$ & 171,600 & 243,750 \\
\hline 095 & 31 & 6.04 & $1000 x$ & $<2000$ & $<2000$ & 619,200 & 512,500 \\
\hline 096 & 36 & 5.83 & $1000 x$ & $<2000$ & $<2000$ & 374,300 & 321,000 \\
\hline 098 & 041 & 5.92 & $1000 x$ & $<2000$ & $<2000$ & 214,500 & 181,200 \\
\hline 099 & 46 & 5.17 & $100 x$ & $<2000$ & $<2000$ & $2 J$ & $2 \mathrm{~J}$ \\
\hline 100 & 48 & 5.08 & $100 x$ & $<2000$ & $<2000$ & 83,900 & 77,600 \\
\hline 101 & $48 \mathrm{D}$ & 4.67 & $100 x$ & $<2000$ & $<2000$ & 140,700 & 150,650 \\
\hline 094 & $30 W$ & $N A$ & $1000 x$ & $<2000$ & $<2000$ & 539,400 & NA \\
\hline 097 & $40 W$ & $N A$ & $1000 x$ & $<2000$ & $<2000$ & 719,000 & $N A$ \\
\hline
\end{tabular}

Pre-T4B4

$\begin{array}{llllllll}\text { Sample } & \text { Depth } & \text { Weight, g } & \text { Dilution } & \begin{array}{l}\text { cis-DCE, } \\ \text { gross }\end{array} & \begin{array}{l}\text { cis-DCE, } \\ \mu \mathbf{g} / \mathbf{k g}\end{array} & \begin{array}{l}\text { TCE, } \\ \text { gross }\end{array} & \begin{array}{l}\text { TCE, } \\ \mu \mathrm{g} / \mathbf{k g}\end{array} \\ 195 & 01 & 5.96 & 1 \mathrm{x} & <2000 & <2000 & <5.0 & <5.0 \\ 196 & 06 & 5.28 & 1 \mathrm{x} & <2000 & <2000 & 2 \mathrm{~J} & 2 \mathrm{~J} \\ 197 & 11 & 3.79 & 100 \mathrm{x} & <2000 & <2000 & 14,640 & 19,300 \\ 198 & 11 \mathrm{D} & 6.16 & 100 \mathrm{x} & <2000 & <2000 & 24,290 & 19,700 \\ 199 & 15 & 5.98 & 1000 \mathrm{x} & <2000 & <2000 & 304,900 & 254,950 \\ 200 & 16 & 5.13 & 100 \mathrm{x} & <2000 & <2000 & 571,200 & 556,500 \\ 201 & 21 & 6.30 & 100 \mathrm{x} & 100,000 \mathrm{~J} & 79,450 \mathrm{~J} & 60,790 & 48,250 \\ 202 & 25 & 6.97 & 1000 \mathrm{x} & <2000 & <2000 & 139,455 & 100,050 \\ 203 & 26 & 4.12 & 100 \mathrm{x} & <2000 & <2000 & 109,100 & 132,400 \\ 204 & 30 & 3.75 & 1000 \mathrm{x} & <2000 & <2000 & 1,250,000 & 1,666,500 \\ 206 & 31 & 5.82 & 1000 \mathrm{x} & <2000 & <2000 & 353,000 & 303,250 \\ 207 & 31 \mathrm{D} & 4.75 & 1000 \mathrm{x} & <2000 & <2000 & 388,000 & 408,400 \\ 208 & 34 & 4.16 & 100 \mathrm{x} & <2000 & <2000 & 38,300 & 46,050 \\ 209 & 35 & 5.49 & 100 \mathrm{x} & <2000 & <2000 & 10,170 & 9250 \\ 210 & 36 & 5.76 & 1 \mathrm{x} & 15,160 & 13,150 & 11.5 & 10 \\ 213 & 41 & 5.92 & 100 \mathrm{x} & <2000 & <2000 & 103,600 & 87,500 \\ 214 & 46 & 6.00 & 1 \mathrm{x} & <2000 & <2000 & 30.2 & 25 \\ 215 & 48 & 6.26 & 10 \mathrm{x} & <2000 & <2000 & 13,310 & 10,650 \\ & & & & & & & \\ 205 & 30 W & N A & 10,000 x & <2000 & N A & 12,450,000 & N A \\ 211 & 40 W & N A & 10,000 x & <2000 & N A & 5,330,000 & N A \\ 216 & 48 W & N A & 10,000 x & <2000 & N A & 2,530,000 & N A\end{array}$


Pre-T4B5

\begin{tabular}{|c|c|c|c|c|c|c|c|}
\hline Sample & Depth & Weight, g & Dilution & $\begin{array}{l}\text { cis-DCE, } \\
\text { gross }\end{array}$ & $\begin{array}{l}\text { cis-DCE, } \\
\mu \mathrm{g} / \mathrm{kg}\end{array}$ & $\begin{array}{l}\text { TCE, } \\
\text { gross }\end{array}$ & $\begin{array}{l}\text { TCE, } \\
\mu \mathrm{g} / \mathrm{kg}\end{array}$ \\
\hline 177 & 01 & 4.50 & $1 x$ & $<2000$ & $<2000$ & $<5.0$ & $<5.0$ \\
\hline 178 & 06 & 4.65 & $1 x$ & $<2000$ & $<2000$ & $<5.0$ & $<5.0$ \\
\hline 179 & $06 \mathrm{D}$ & 6.61 & $1 x$ & $<2000$ & $<2000$ & $<5.0$ & $<5.0$ \\
\hline 180 & 11 & 5.73 & $10 x$ & 24,200 & 21,100 & $<5.0$ & $<5.0$ \\
\hline 181 & 15 & 5.79 & $100 x$ & $<2000$ & $<2000$ & 22,780 & 19,650 \\
\hline 182 & 16 & 5.45 & $10 x$ & 87,190 & 80,000 & 15,000 & 14,750 \\
\hline 183 & 20 & 5.05 & $1 x$ & 36,750 & 36,400 & $2 \mathrm{~J}$ & $2 \mathrm{~J}$ \\
\hline 184 & 21 & 4.85 & $1 x$ & 26,120 & 26,950 & 9.3 & 10 \\
\hline 185 & 26 & 5.71 & $100 x$ & $<2000$ & $<2000$ & 20,830 & 18,250 \\
\hline 186 & 30 & 6.20 & $1000 x$ & $<2000$ & $<2000$ & $1,314,000$ & $1,059,500$ \\
\hline 188 & 31 & 6.17 & $1000 x$ & $<2000$ & $<2000$ & $1,384,000$ & $1,121,500$ \\
\hline 189 & 36 & 5.82 & $1 x$ & 3390 & 2910 & $2 \mathrm{~J}$ & $2 \mathrm{~J}$ \\
\hline 191 & 41 & 4.98 & $10 x$ & $<2000$ & $<2000$ & 2630 & 2640 \\
\hline 192 & 46 & 4.99 & $1 x$ & $<2000$ & $<2000$ & 9.0 & 10 \\
\hline 193 & 47 & 5.84 & $100 \mathrm{x}$ & $<2000$ & $<2000$ & 23,370 & 20,000 \\
\hline 187 & $30 W$ & $N A$ & $10,000 x$ & $<2000$ & $N A$ & $9,016,000$ & $N A$ \\
\hline 190 & $40 W$ & $N A$ & $10,000 x$ & $<2000$ & $N A$ & $2,840,000$ & $N A$ \\
\hline 194 & $48 W$ & $N A$ & $10,000 x$ & $<2000$ & $N A$ & $1,690,000$ & $N A$ \\
\hline
\end{tabular}

D: soil sample duplicate

$\mathrm{J}$ : estimated concentration

NA: not applicable

W: groundwater sample (denoted by italics and shading)

WD: groundwater sample duplicate 
B-11

Pre-treatment samples from T5 Cell

Pre-T5B1

$\begin{array}{llllllll}\text { Sample } & \text { Depth } & \text { Weight, g } & \text { Dilution } & \begin{array}{l}\text { cis-DCE, } \\ \text { gross }\end{array} & \begin{array}{l}\text { cis-DCE, } \\ \mu \mathrm{g} / \mathbf{k g}\end{array} & \begin{array}{l}\text { TCE, } \\ \text { gross }\end{array} & \begin{array}{l}\text { TCE, } \\ \mu \mathrm{g} / \mathrm{kg}\end{array} \\ 328 & 01 & 5.89 & 1 \mathrm{x} & <2000 & <2000 & <5.0 & <5.0 \\ 329 & 06 & 5.84 & 1 \mathrm{x} & <2000 & <2000 & <5.0 & <5.0 \\ 330 & 11 & 6.22 & 10 \mathrm{x} & <2000 & <2000 & 12,730 & 10,230 \\ 331 & 15 & 6.00 & 1000 \mathrm{x} & <2000 & <2000 & 601,700 & 501,400 \\ 332 & 16 & 6.07 & 1000 \mathrm{x} & <2000 & <2000 & 107,800 & 88,800 \\ 333 & 21 & 5.49 & 1000 \mathrm{x} & <2000 & <2000 & 37,050 & 33,740 \\ 334 & 25 & 6.90 & 10 \mathrm{x} & <2000 & <2000 & 2590 & 1880 \\ & & & & & & & \\ 336 & 25 W & N A & 100 x & <2000 & <2000 & 57,200 & N A\end{array}$

Pre-T5B2

\begin{tabular}{|c|c|c|c|c|c|c|c|}
\hline Sample & Depth & Weight, g & Dilution & $\begin{array}{l}\text { cis-DCE, } \\
\text { gross }\end{array}$ & $\begin{array}{l}\text { cis-DCE, } \\
\mu \mathrm{g} / \mathrm{kg}\end{array}$ & $\begin{array}{l}\text { TCE, } \\
\text { gross }\end{array}$ & $\begin{array}{l}\text { TCE, } \\
\mu \mathrm{g} / \mathrm{kg}\end{array}$ \\
\hline 308 & 01 & 6.01 & $1 x$ & $<2000$ & $<2000$ & $<5.0$ & $<5.0$ \\
\hline 309 & 06 & 5.75 & $1 x$ & $<2000$ & $<2000$ & $<5.0$ & $<5.0$ \\
\hline 310 & 11 & 5.69 & $100 x$ & $<2000$ & $<2000$ & 18,920 & 16,620 \\
\hline 311 & 15 & 5.69 & $100 x$ & $<2000$ & $<2000$ & 34,700 & 30,490 \\
\hline 312 & 16 & 6.65 & $1000 x$ & $<2000$ & $<2000$ & 264,300 & 198,700 \\
\hline 317 & 21 & 5.82 & $100 x$ & $<2000$ & $<2000$ & 58,540 & 50,290 \\
\hline 318 & $21 D$ & unk & $100 x$ & $<2000$ & unk & 83,340 & unk \\
\hline 319 & 25 & 5.83 & $1 x$ & $<2000$ & $<2000$ & 182 & 156 \\
\hline 324 & 27 & 5.35 & $1 x$ & $<2000$ & $<2000$ & 562 & 525 \\
\hline 320 & $25 W$ & $N A$ & $10 x$ & $<2000$ & $N A$ & 11,170 & $N A$ \\
\hline 321 & $25 W D$ & $N A$ & $10 x$ & $<2000$ & $N A$ & 13,020 & $N A$ \\
\hline
\end{tabular}

Pre-T5B3

$\begin{array}{llllllll}\text { Sample } & \text { Depth } & \text { Weight, g } & \text { Dilution } & \begin{array}{l}\text { cis-DCE, } \\ \text { gross }\end{array} & \begin{array}{l}\text { cis-DCE, } \\ \mu \mathrm{g} / \mathrm{kg}\end{array} & \begin{array}{l}\text { TCE, } \\ \text { gross }\end{array} & \begin{array}{l}\text { TCE, } \\ \mu \mathrm{g} / \mathrm{kg}\end{array} \\ 104 & 01 & 4.55 & 1 \mathrm{x} & <2000 & <2000 & <5.0 & <5.0 \\ 105 & 06 & 5.07 & 1 \mathrm{x} & <2000 & <2000 & 225 & 220 \\ 106 & 11 & 6.14 & 100 \mathrm{x} & <2000 & <2000 & 37,830 & 30,800 \\ 107 & 15 & 6.48 & 1000 \mathrm{x} & <2000 & <2000 & 106,900 & 82,500 \\ 108 & 16 & 4.29 & 1000 \mathrm{x} & <2000 & <2000 & 313,700 & 365,600 \\ 109 & 20 & 4.89 & 1000 \mathrm{x} & <2000 & <2000 & 308,300 & 315,250 \\ 110 & 22 & 5.11 & 100 \mathrm{x} & 247,200 & 241,900 & 29,030 & 28,400 \\ 111 & 24 & 6.45 & 1 \times & 31,860 & 24,700 & 3440 & 2665 \\ 112 & 25 W & N A & 1 x & 22,250 & N A & 5370 & N A \\ 113 & 25 W D & N A & 1 x & 21,550 & N A & 5330 & N A\end{array}$




\section{B-12}

Pre-T5B4

\begin{tabular}{llllllll}
\hline Sample & Depth & Weight, g & Dilution & $\begin{array}{l}\text { cis-DCE, } \\
\text { gross }\end{array}$ & $\begin{array}{l}\text { cis-DCE, } \\
\mu \mathrm{g} / \mathrm{kg}\end{array}$ & $\begin{array}{l}\text { TCE, } \\
\text { gross }\end{array}$ & $\begin{array}{l}\text { TCE, } \\
\mu \mathrm{g} / \mathrm{kg}\end{array}$ \\
297 & 01 & 5.92 & $1 \mathrm{x}$ & $<2000$ & $<2000$ & $<5.0$ & $<5.0$ \\
298 & 06 & 5.41 & $1 \mathrm{x}$ & $<2000$ & $<2000$ & 51.6 & 47.7 \\
299 & $06 \mathrm{D}$ & 5.83 & $1 \mathrm{x}$ & $<2000$ & $<2000$ & 43.7 & 37.3 \\
300 & 11 & 5.38 & $10 \mathrm{x}$ & $<2000$ & $<2000$ & 11,860 & 11,020 \\
304 & 16 & 5.23 & $1000 \mathrm{x}$ & $<2000$ & $<2000$ & 197,400 & 188,700 \\
305 & 25 & 5.42 & $1 \mathrm{x}$ & $<2000$ & $<2000$ & 142 & 131 \\
306 & 21 & 6.04 & $100 \mathrm{x}$ & $<2000$ & $<2000$ & 11,840 & 9800 \\
307 & $25 W$ & $N A$ & $10 x$ & $<2000$ & $N A$ & 4900 & $N A$
\end{tabular}

Pre-T5B5

\begin{tabular}{|c|c|c|c|c|c|c|c|}
\hline Sample & Depth & Weight, g & Dilution & $\begin{array}{l}\text { cis-DCE, } \\
\text { gross }\end{array}$ & $\begin{array}{l}c i s-D C E \\
\mu \mathrm{g} / \mathrm{kg}\end{array}$ & $\begin{array}{l}\text { TCE, } \\
\text { gross }\end{array}$ & $\begin{array}{l}\text { TCE, } \\
\mu \mathrm{g} / \mathrm{kg}\end{array}$ \\
\hline 289 & 01 & 5.62 & $1 x$ & $<2000$ & $<2000$ & $<5.0$ & $<5.0$ \\
\hline 290 & 06 & 5.14 & $1 x$ & $<2000$ & $<2000$ & $2 \mathrm{~J}$ & $2 \mathrm{~J}$ \\
\hline 291 & 11 & 7.14 & $1 \mathrm{x}$ & $<2000$ & $<2000$ & 340 & 238 \\
\hline 292 & 16 & 6.01 & $1 x$ & $<2000$ & $<2000$ & $<5.0$ & $<5.0$ \\
\hline 293 & 25 & 5.66 & $1 x$ & $<2000$ & $<2000$ & $<5.0$ & $<5.0$ \\
\hline 294 & $25 \mathrm{D}$ & 5.68 & $1 x$ & $<2000$ & $<2000$ & $<5.0$ & $<5.0$ \\
\hline 295 & $25 W$ & $N A$ & $1 x$ & $<2000$ & $N A$ & 71 & $N A$ \\
\hline
\end{tabular}

D: soil sample duplicate

$\mathrm{J}$ : estimated concentration

NA: not applicable

unk: unknown

W: groundwater sample (denoted by italics and shading)

WD: groundwater sample duplicate 
Pre-treatment samples from T6 Cell

Pre-T6B1

\begin{tabular}{|c|c|c|c|c|c|c|c|}
\hline Sample & Depth & Weight, g & Dilution & $\begin{array}{l}\text { cis-DCE, } \\
\text { gross }\end{array}$ & $\begin{array}{l}\text { cis-DCE, } \\
\mu \mathrm{g} / \mathrm{kg}\end{array}$ & $\begin{array}{l}\text { TCE, } \\
\text { gross }\end{array}$ & $\begin{array}{l}\text { TCE, } \\
\mu \mathrm{g} / \mathrm{kg}\end{array}$ \\
\hline 410 & 01 & 6.27 & $1 \mathrm{x}$ & $<2000$ & $<2000$ & $<5.0$ & $<5.0$ \\
\hline 411 & 06 & 5.89 & $1 x$ & $<2000$ & $<2000$ & 57 & 48 \\
\hline 412 & $06 \mathrm{D}$ & 6.55 & $1 \mathrm{x}$ & $<2000$ & $<2000$ & 98 & 75 \\
\hline 413 & 11 & 6.20 & $1 \mathrm{x}$ & $<2000$ & $<2000$ & 5 & 5 \\
\hline 414 & 16 & 5.60 & $10 x$ & $<2000$ & $<2000$ & 5220 & 4660 \\
\hline 415 & 21 & 5.85 & $1000 x$ & $<2000$ & $<2000$ & 377,200 & 322,400 \\
\hline 416 & 26 & 6.07 & $100 x$ & $<2000$ & $<2000$ & 19,600 & 16,100 \\
\hline 418 & 31 & 5.03 & $10 x$ & $<2000$ & $<2000$ & 14,000 & 13,900 \\
\hline 419 & 36 & 6.00 & $10 x$ & $<2000$ & $<2000$ & 5400 & 4500 \\
\hline 421 & 41 & 3.83 & $1 x$ & $<2000$ & $<2000$ & $<5.0$ & $<5.0$ \\
\hline 422 & 46 & 5.88 & $1 \mathrm{x}$ & $<2000$ & $<2000$ & 199 & 169 \\
\hline 423 & 47.5 & 6.15 & $10 \mathrm{x}$ & $<2000$ & $<2000$ & 8190 & 6660 \\
\hline 417 & $30 W$ & $N A$ & $1000 x$ & $<2000$ & $<2000$ & 48,700 & $N A$ \\
\hline 420 & $40 W$ & $N A$ & $100 x$ & $<2000$ & $<2000$ & 48,500 & $N A$ \\
\hline 424 & $475 W$ & $N A$ & $100 x$ & $<2000$ & $<2000$ & 23,800 & $N A$ \\
\hline
\end{tabular}

Pre-T6B2

\begin{tabular}{|c|c|c|c|c|c|c|c|}
\hline Sample & Depth & Weight, $g$ & Dilution & $\begin{array}{l}\text { cis-DCE, } \\
\text { gross }\end{array}$ & $\begin{array}{l}\text { cis-DCE, } \\
\mu \mathrm{g} / \mathrm{kg}\end{array}$ & $\begin{array}{l}\text { TCE, } \\
\text { gross }\end{array}$ & $\begin{array}{l}\text { TCE, } \\
\mu \mathrm{g} / \mathrm{kg}\end{array}$ \\
\hline 392 & 01 & 5.84 & $1 x$ & $<2000$ & $<2000$ & $<5.0$ & $<5.0$ \\
\hline 393 & 06 & 4.64 & $1 \mathrm{x}$ & $<2000$ & $<2000$ & $<5.0$ & $<5.0$ \\
\hline 394 & 11 & 6.23 & $1 x$ & $<2000$ & $<2000$ & $<5.0$ & $<5.0$ \\
\hline 395 & 15 & 5.88 & $100 x$ & $<2000$ & $<2000$ & 28,600 & 24,300 \\
\hline 396 & $15 \mathrm{D}$ & 5.95 & $100 x$ & $<2000$ & $<2000$ & 30,950 & 26,000 \\
\hline 397 & 20 & 5.00 & $1000 x$ & $<2000$ & $<2000$ & 300,400 & 300,400 \\
\hline 398 & 16 & 6.30 & $100 x$ & $<2000$ & $<2000$ & 34,300 & 27,200 \\
\hline 399 & 21 & 6.04 & $1000 x$ & $<2000$ & $<2000$ & 804,150 & 665,700 \\
\hline 400 & 26 & 6.79 & $100 x$ & $<2000$ & $<2000$ & 27,900 & 20,500 \\
\hline 402 & 31 & 5.77 & $100 x$ & $<2000$ & $<2000$ & 113,900 & 98,700 \\
\hline 403 & 36 & 6.50 & $100 x$ & $<2000$ & $<2000$ & 37,300 & 28,700 \\
\hline 406 & 41 & 6.09 & $100 \mathrm{x}$ & $<2000$ & $<2000$ & $200 \mathrm{~J}$ & $200 \mathrm{~J}$ \\
\hline 407 & 46 & 5.29 & $1 x$ & $<2000$ & $<2000$ & 307 & 290 \\
\hline 408 & 48 & 6.19 & $10 x$ & $<2000$ & $<2000$ & 7610 & 6150 \\
\hline 401 & $30 W$ & $N A$ & $1000 x$ & $<2000$ & $<2000$ & 251,200 & $N A$ \\
\hline 404 & $40 W$ & $N A$ & $100 x$ & $<2000$ & $<2000$ & 161200 & $N A$ \\
\hline 409 & $48 W$ & $N A$ & $100 x$ & $<2000$ & $<2000$ & 80,100 & $N A$ \\
\hline
\end{tabular}




\section{B-14}

Pre-T6B3

\begin{tabular}{llllllll}
\hline Sample & Depth & Weight, & Dilution & $\begin{array}{l}\text { cis-DCE, } \\
\text { gross }\end{array}$ & $\begin{array}{l}\text { cis-DCE, } \\
\mu \text { g/kg }\end{array}$ & $\begin{array}{l}\text { TCE, } \\
\text { gross }\end{array}$ & $\begin{array}{l}\text { TCE, } \\
\mu \mathrm{g} / \mathrm{kg}\end{array}$ \\
374 & 01 & 6.91 & $1 \mathrm{x}$ & $<2000$ & $<2000$ & $<5.0$ & $<5.0$ \\
375 & 06 & 9.72 & $1 \mathrm{x}$ & $<2000$ & $<2000$ & $2 \mathrm{~J}$ & $2 \mathrm{~J}$ \\
376 & 15 & 6.45 & $100 \mathrm{x}$ & $<2000$ & $<2000$ & 14,400 & 11,160 \\
377 & 11 & 5.43 & $1 \mathrm{x}$ & $<2000$ & $<2000$ & $<5.0$ & $<5.0$ \\
& & & & & & & \\
378 & 16 & 5.95 & $100 \mathrm{x}$ & $<2000$ & $<2000$ & 61,200 & 51,400 \\
379 & 21 & 5.14 & $10,000 \mathrm{x}$ & $<2000$ & $<2000$ & $1,004,000$ & 976,700 \\
380 & $21 \mathrm{D}$ & 5.69 & $10,000 \mathrm{x}$ & $<2000$ & $<2000$ & 915,000 & 804,000 \\
381 & 30 & 5.02 & $100 \mathrm{x}$ & $<2000$ & $<2000$ & 7240 & 7210 \\
& & & & & & & \\
382 & 26 & 4.75 & $100 \mathrm{x}$ & $<2000$ & $<2000$ & 1730 & 1820 \\
384 & 31 & 3.93 & $100 \mathrm{x}$ & $<2000$ & $<2000$ & 481,700 & 612,800 \\
385 & 36 & 5.19 & $100 \mathrm{x}$ & $<2000$ & $<2000$ & 82,800 & 79,800 \\
387 & 41 & 5.43 & $1 \mathrm{x}$ & $<2000$ & $<2000$ & 269 & 248 \\
& & & & & & & \\
388 & 46 & 5.89 & $10 \mathrm{x}$ & $<2000$ & $<2000$ & 2344 & 1990 \\
389 & 48 & 6.58 & $1 \mathrm{x}$ & $<2000$ & $<2000$ & 459 & 349 \\
& & & & & & & \\
383 & $30 W$ & $N A$ & $1000 x$ & $<2000$ & $<2000$ & 347,400 & $N A$ \\
386 & $40 W$ & $N A$ & $1000 x$ & $<2000$ & $<2000$ & 605,800 & $N A$ \\
\hline 390 & $48 W$ & $N A$ & $1000 x$ & $<2000$ & $<2000$ & 173,900 & $N A$ \\
\hline 391 & $48 W D$ & $N A$ & $100 x$ & $<2000$ & $<2000$ & 183,800 & $N A$ \\
\hline & & & & & & &
\end{tabular}


Pre-T6B4

$\begin{array}{llllllll}\text { Sample } & \text { Depth } & \text { Weight, } & \text { Dilution } & \begin{array}{c}\text { cis-DCE, } \\ \text { gross }\end{array} & \begin{array}{l}\text { cis-DCE, } \\ \mu \mathrm{g} / \mathbf{k g}\end{array} & \begin{array}{l}\text { TCE, } \\ \text { gross }\end{array} & \begin{array}{l}\text { TCE, } \\ \mu \mathrm{g} / \mathrm{kg}\end{array} \\ 356 & 01 & 6.66 & 1 \mathrm{x} & <2000 & <2000 & <5.0 & <5.0 \\ 357 & 06 & 6.06 & 1 \mathrm{x} & <2000 & <2000 & <5.0 & <5.0 \\ 358 & 11 & 6.19 & 1 \mathrm{x} & <2000 & <2000 & <5.0 & <5.0 \\ 359 & 16 & 5.72 & 1000 \mathrm{x} & <2000 & <2000 & 541,600 & 473,400 \\ & & & & & & & \\ 360 & 20 & 5.33 & 1000 \mathrm{x} & <2000 & <2000 & 242,100 & 227,000 \\ 361 & 21 & 5.24 & 100 \mathrm{x} & <2000 & <2000 & 107,100 & 102,200 \\ 362 & 21 \mathrm{D} & 5.43 & 1000 \mathrm{x} & <2000 & <2000 & 239,000 & 220,100 \\ 363 & 26 & 5.98 & 1000 \mathrm{x} & <2000 & <2000 & 3,100,000 & 2,600,000 \\ & & & & & & & \\ 365 & 31 & 5.88 & 1000 \mathrm{x} & <2000 & <2000 & 625,500 & 531,900 \\ 366 & 36 & 4.83 & 1000 \mathrm{x} & <2000 & <2000 & 419,000 & 433,700 \\ 367 & 36 \mathrm{D} & 6.21 & 1000 \mathrm{x} & <2000 & <2000 & 376,000 & 302,700 \\ 369 & 41 & 5.51 & 10 \mathrm{x} & <2000 & <2000 & 235 & 213 \\ & & & & & & & \\ 370 & 45 & 6.35 & 100 \mathrm{x} & <2000 & <2000 & 78,500 & 61,810 \\ 371 & 46 & 6.46 & 1 \mathrm{x} & <2000 & <2000 & 169 & 130 \\ 372 & 48 & 6.12 & 1000 \mathrm{x} & <2000 & <2000 & 469 & 383 \\ & & & & & & & \\ 364 & 30 W & N A & 10,000 \times & <2000 & <2000 & 8,250,000 & N A \\ 368 & 40 W & N A & 10,000 \times & <2000 & <2000 & 4,800,000 & N A \\ 373 & 48 W & N A & 10,000 x & <2000 & <2000 & 2,030,000 & N A \\ & & & & & & & \end{array}$


Pre-T6B5

\begin{tabular}{|c|c|c|c|c|c|c|c|}
\hline Sample & Depth & Weight, g & Dilution & $\begin{array}{l}\text { cis-DCE, } \\
\text { gross }\end{array}$ & $\begin{array}{l}\text { cis-DCE, } \\
\mu \mathrm{g} / \mathrm{kg}\end{array}$ & $\begin{array}{l}\text { TCE, } \\
\text { gross }\end{array}$ & $\begin{array}{l}\text { rCE, } \\
\mathrm{lg} / \mathrm{kg}\end{array}$ \\
\hline 337 & 01 & 3.09 & $1 x$ & $<2000$ & $<2000$ & $<5.0$ & $<5.0$ \\
\hline 338 & 06 & 4.08 & $1 \mathrm{x}$ & $<2000$ & $<2000$ & $<5.0$ & $<5.0$ \\
\hline 339 & 11 & 5.51 & $1 x$ & $<2000$ & $<2000$ & $<5.0$ & $<5.0$ \\
\hline 340 & 15 & 5.59 & $1000 x$ & $<2000$ & $<2000$ & 334,500 & 299,200 \\
\hline 341 & 16 & 5.98 & $1000 x$ & $<2000$ & $<2000$ & 104,700 & 87,500 \\
\hline 342 & $16 \mathrm{D}$ & 5.98 & $1000 x$ & $<2000$ & $<2000$ & 130,300 & 109,000 \\
\hline 343 & 21 & 4.38 & $1 x$ & $<2000$ & $<2000$ & 709 & 809 \\
\hline 344 & 26 & 5.25 & $1000 x$ & $<2000$ & $<2000$ & 317,200 & 302,100 \\
\hline 345 & 30 & 5.95 & $10,000 x$ & $<2000$ & $<2000$ & $1,700,000$ & $1,400,000$ \\
\hline 347 & 31 & 5.25 & $10,000 x$ & $<2000$ & $<2000$ & $4,000,000$ & $3,800,000$ \\
\hline 348 & 36 & 6.26 & $1000 x$ & $<2000$ & $<2000$ & 547,400 & 437,200 \\
\hline 349 & 40 & 6.89 & $1000 x$ & $<2000$ & $<2000$ & 917,900 & 666,000 \\
\hline 351 & 41 & 4.33 & $100 x$ & $<2000$ & $<2000$ & 45,300 & 52,400 \\
\hline 352 & 46 & 5.77 & $1 \mathrm{x}$ & $<2000$ & $<2000$ & $<5.0$ & $<5.0$ \\
\hline 353 & 48.5 & 6.11 & $100 x$ & $<2000$ & $<2000$ & 18,130 & 14,800 \\
\hline 346 & $30 W$ & $N A$ & $100,000 x$ & $<2000$ & $N A$ & $11,200,000$ & $N A$ \\
\hline 350 & $40 W$ & $N A$ & $10,000 x$ & $<2000$ & $N A$ & $6,500,000$ & $N A$ \\
\hline 355 & 48.5 & $N A$ & $10,000 x$ & $<2000$ & $N A$ & $1,500,000$ & $N A$ \\
\hline
\end{tabular}

D: soil sample duplicate $\mathrm{J}$ : estimated concentration NA: not applicable W: groundwater sample (denoted by italics and shading) WD: groundwater sample duplicate 


\section{Pre-treatment samples from T7 Cell}

Pre-T7B1

\begin{tabular}{|c|c|c|c|c|c|c|c|}
\hline Sample & Depth & Weight, $g$ & Dilution & $\begin{array}{l}\text { cis-DCE, } \\
\text { gross }\end{array}$ & $\begin{array}{l}\text { cis-DCE, } \\
\mu \mathrm{g} / \mathrm{kg}\end{array}$ & $\begin{array}{l}\text { TCE, } \\
\text { gross }\end{array}$ & $\begin{array}{l}\text { TCE, } \\
\mu \mathrm{g} / \mathrm{kg}\end{array}$ \\
\hline 441 & 01 & 6.18 & $1 x$ & $<2000$ & $<2000$ & $<5.0$ & $<5.0$ \\
\hline 442 & $01 \mathrm{D}$ & 6.31 & $1 x$ & $<2000$ & $<2000$ & $<5.0$ & $<5.0$ \\
\hline 443 & 06 & 6.03 & $1 x$ & $<2000$ & $<2000$ & $<5.0$ & $<5.0$ \\
\hline 444 & 11 & 6.31 & $100 x$ & $<2000$ & $<2000$ & 52,000 & 41,200 \\
\hline 445 & 16 & 5.12 & $100 x$ & $<2000$ & $<2000$ & 28,315 & 27,700 \\
\hline 446 & 21 & 4.19 & $10 x$ & $<2000$ & $<2000$ & 1317 & 1570 \\
\hline 447 & 25 & 5.35 & $1 x$ & $<2000$ & $<2000$ & $<5.0$ & $<5.0$ \\
\hline 448 & $25 W$ & $N A$ & $10 x$ & $<2000$ & 2000 & 1729 & $N A$ \\
\hline
\end{tabular}

Pre-T7B2

$\begin{array}{llllllll}\text { Sample } & \text { Depth } & \text { Weight, g } & \text { Dilution } & \begin{array}{l}\text { cis-DCE, } \\ \text { gross }\end{array} & \begin{array}{l}\text { cis-DCE, } \\ \mu \text { g/kg }\end{array} & \begin{array}{l}\text { TCE, } \\ \text { gross }\end{array} & \begin{array}{l}\text { TCE, } \\ \mu \text { g/kg }\end{array} \\ 433 & 01 & 6.58 & 1 \mathrm{x} & <2000 & <2000 & <5.0 & <5.0 \\ 434 & 06 & 5.75 & 1 \mathrm{x} & <2000 & <2000 & <5.0 & <5.0 \\ 435 & 11 & 6.19 & 100 \mathrm{x} & <2000 & <2000 & 28,700 & 23,200 \\ 436 & 15 & 4.90 & 100 \mathrm{x} & <2000 & <2000 & 151,900 & 155,000 \\ 437 & 16 & 5.02 & 100 \mathrm{x} & <2000 & <2000 & 42,900 & 42,800 \\ 438 & 21 & 7.03 & 10 \mathrm{x} & <2000 & <2000 & 640 & 455 \\ 439 & 25 & 6.39 & 1 \mathrm{x} & <2000 & <2000 & 595 & 466 \\ 440 & 25 W & N A & 10 x & <2000 & <2000 & 2179 & N A\end{array}$

Pre-T7B3

$\begin{array}{llllllll}\text { Sample } & \text { Depth } & \text { Weight, g } & \text { Dilution } & \begin{array}{l}\text { cis-DCE, } \\ \text { gross }\end{array} & \begin{array}{l}\text { cis-DCE, } \\ \mu \text { g/kg }\end{array} & \begin{array}{l}\text { TCE, } \\ \text { gross }\end{array} & \begin{array}{l}\text { TCE, } \\ \mu \text { g/kg }\end{array} \\ 425 & 01 & 6.29 & 1 \mathrm{x} & <2000 & <2000 & <5.0 & <5.0 \\ 426 & 06 & 6.55 & 1 \mathrm{x} & <2000 & <2000 & <5.0 & <5.0 \\ 427 & 11 & 5.85 & 100 \mathrm{x} & <2000 & <2000 & 17,480 & 14,900 \\ 428 & 11 \mathrm{D} & 5.78 & 100 \mathrm{x} & <2000 & <2000 & 16,210 & 14,000 \\ 429 & 16 & 5.49 & 100 \mathrm{x} & <2000 & <2000 & 37,300 & 33,970 \\ 430 & 21 & 5.53 & 10 \mathrm{x} & <2000 & <2000 & 1715 & 1550 \\ 431 & 25 & 6.36 & 10 \mathrm{x} & <2000 & <2000 & 547 & 430 \\ 432 & 25 W & N A & 10 x & <2000 & <2000 & 975 & N A\end{array}$




\section{B-18}

Pre-T7B4

\begin{tabular}{|c|c|c|c|c|c|c|c|}
\hline Sample & Depth & Weight, g & Dilution & $\begin{array}{l}\text { cis-DCE, } \\
\text { gross }\end{array}$ & $\begin{array}{l}\text { cis-DCE, } \\
\mu \mathrm{g} / \mathrm{kg}\end{array}$ & $\begin{array}{l}\text { TCE, } \\
\text { gross }\end{array}$ & $\begin{array}{l}\text { TCE, } \\
\mu \mathrm{g} / \mathrm{kg}\end{array}$ \\
\hline 449 & 01 & 6.36 & $1 x$ & $<2000$ & $<2000$ & $<5.0$ & $<5.0$ \\
\hline 450 & 06 & 5.75 & $1 x$ & $<2000$ & $<2000$ & $<5.0$ & $<5.0$ \\
\hline 451 & 11 & 5.61 & $10 x$ & $<2000$ & $<2000$ & 11,530 & 10,280 \\
\hline 452 & 16 & 5.77 & $100 x$ & $<2000$ & $<2000$ & 49,370 & 42,780 \\
\hline 453 & 21 & 4.62 & $1 x$ & $<2000$ & $<2000$ & 188 & 174 \\
\hline 454 & $21 D$ & 5.39 & $1 x$ & $<2000$ & $<2000$ & 156 & 145 \\
\hline 455 & 25 & 5.76 & $1 x$ & $<2000$ & $<2000$ & $<5.0$ & $<5.0$ \\
\hline 456 & $25 W$ & $N A$ & $1 x$ & $<2000$ & $<2000$ & 497 & $N A$ \\
\hline 457 & $25 W D$ & $N A$ & $1 x$ & $<2000$ & $<2000$ & 718 & $N A$ \\
\hline
\end{tabular}

Pre-T7B5

\begin{tabular}{llllllll}
\hline Sample & Depth & Weight, g & Dilution & $\begin{array}{c}\text { cis-DCE, } \\
\text { gross }\end{array}$ & $\begin{array}{l}\text { cis-DCE, } \\
\mu \text { g/kg }\end{array}$ & $\begin{array}{l}\text { TCE, } \\
\text { gross }\end{array}$ & $\begin{array}{l}\text { TCE, } \\
\mu \text { g/kg }\end{array}$ \\
458 & 01 & 5.87 & $1 \mathrm{x}$ & $<2000$ & $<2000$ & $<5.0$ & $<5.0$ \\
459 & 06 & 6.26 & $1 \mathrm{x}$ & $<2000$ & $<2000$ & $<5.0$ & $<5.0$ \\
460 & 11 & 5.47 & $100 \mathrm{x}$ & $<2000$ & $<2000$ & 70,600 & 64,530 \\
461 & 15 & 4.59 & $1000 \mathrm{x}$ & $<2000$ & $<2000$ & 201,300 & 219,300 \\
462 & 16 & 5.59 & $1000 \mathrm{x}$ & $<2000$ & $<2000$ & 86,100 & 77,010 \\
463 & 21 & 5.26 & $10 \mathrm{x}$ & $<2000$ & $<2000$ & 3220 & 3060 \\
464 & 25 & 6.13 & $10 \mathrm{x}$ & $<2000$ & $<2000$ & 420 & 342 \\
465 & $25 W$ & $N 4$ & $10 x$ & $<2000$ & $<2000$ & 2506 & $\mathrm{NA}$ \\
\hline
\end{tabular}

D: soil sample duplicate

NA: not applicable

W: groundwater sample (denoted by italics and shading)

WD: groundwater sample duplicate 
B-19

Pre-treatment samples from X1 Cell

Pre-X1B1

\begin{tabular}{|c|c|c|c|c|c|c|c|}
\hline Sample & Depth & Weight, g & Dilution & $\begin{array}{c}\text { cis-DCE, } \\
\text { gross }\end{array}$ & $\begin{array}{l}\text { cis-DCE, } \\
\mu \mathrm{g} / \mathrm{kg}\end{array}$ & $\begin{array}{l}\text { TCE, } \\
\text { gross }\end{array}$ & $\begin{array}{l}\text { TCE, } \\
\mu \mathrm{g} / \mathrm{kg}\end{array}$ \\
\hline 003 & 01 & 6.15 & $1 x$ & $<2000$ & $<2000$ & $<5.0$ & $<5.0$ \\
\hline 004 & 06 & 5.20 & $1 x$ & $<2000$ & $<2000$ & $<5.0$ & $<5.0$ \\
\hline 005 & 11 & 5.32 & $1 \mathrm{x}$ & $<2000$ & $<2000$ & $<5.0$ & $<5.0$ \\
\hline 006 & 16 & 5.32 & $1 \mathrm{x}$ & $<2000$ & $<2000$ & $<5.0$ & $<5.0$ \\
\hline 007 & 21 & 5.83 & $1 x$ & $<2000$ & $<2000$ & $<5.0$ & $<5.0$ \\
\hline 008 & 26 & 4.64 & $1 x$ & $<2000$ & $<2000$ & $<5.0$ & $<5.0$ \\
\hline 010 & 31 & 5.32 & $1 x$ & $<2000$ & $<2000$ & $<5.0$ & $<5.0$ \\
\hline 011 & 36 & 6.06 & $1 x$ & $<2000$ & $<2000$ & $<5.0$ & $<5.0$ \\
\hline 013 & 41 & 5.24 & $1 x$ & $<2000$ & $<2000$ & $<5.0$ & $<5.0$ \\
\hline 014 & 46 & 5.17 & $1 x$ & $<2000$ & $<2000$ & $<5.0$ & $<5.0$ \\
\hline 015 & $46 \mathrm{D}$ & 4.11 & $1 x$ & $<2000$ & $<2000$ & $<5.0$ & $<5.0$ \\
\hline 016 & 51 & 4.40 & $1 \mathrm{x}$ & $<2000$ & $<2000$ & $<5.0$ & $<5.0$ \\
\hline 009 & $30 \mathrm{~W}$ & $N A$ & $1 x$ & $<2000$ & $N A$ & $<5.0$ & $<50$ \\
\hline 012 & $40 W$ & $N A$ & $1 x$ & $<2000$ & $N A$ & $<5.0$ & $<5.0$ \\
\hline 017 & $51 W$ & $N A$ & $1 x$ & $<2000$ & $N A$ & $<5.0$ & $<5.0$ \\
\hline
\end{tabular}

D: soil sample duplicate

NA: not applicable

W: groundwater sample (denoted by italics and shading) 
APPENDIX C

Data Acquisition System

FID vs Auger Depth Plots 


\section{Bio-C3 (T3C3) Summary}

Date: $7-11-96$

DAS time start: $10: 29: 14=0 \mathrm{~min}$

DAS time stop: $14: 13: 07=223.88 \mathrm{~min}$

Off-gas sample collection for TCE analysis:

$\begin{array}{llllll}\text { Clock time } & \text { Elapsed time } & \text { Depth, ft } & \text { GC detector } & \begin{array}{l}\text { FID reading, } \\ \text { ppm }\end{array} & \begin{array}{l}\text { TCE, } \\ \text { ppm }\end{array} \\ 11: 06: 46 & 00: 37.53 & 12 & \text { ECD } & 7,500 & \text { ND } \\ 11: 06: 46 & 00: 37.53 & 12 & \text { FID } & 7,500 & \text { ND } \\ 11: 11: 48 & 00: 42.57 & 16 & \text { ECD } & 15,000 & 784 \\ 11: 11: 48 & 00: 42.57 & 16 & \text { FID } & 15,000 & 759 \\ 14: 03: 27 & 03: 57.00 & 16 & \text { ECD } & 2,000 & 286 \\ 14: 03: 27 & 03: 57.00 & 16 & \text { FID } & 2,000 & 374\end{array}$

Process Summary:

Elapsed time

0 to $55 \mathrm{~min}$

55 to $66 \mathrm{~min}$

66 to $86 \mathrm{~min}$

86 to $174 \mathrm{~min}$

174 to $197 \mathrm{~min}$

197 to $205 \mathrm{~min}$

205 to $219 \mathrm{~min}$

219 to $224 \mathrm{~min}$
Process description

An 8-ft diameter hole drilled with air $(700$ to $1000 \mathrm{cfm})$ to a depth of $25 \mathrm{ft}$

Prepare for mixing

344 gal of bacteria mix added between $24 \mathrm{ft}$ and $3 \mathrm{ft}$

Repair shroud seal

Mix column with air ( 800 to $1100 \mathrm{cfm})$ from surface to $24 \mathrm{ft}$

Mix column with air ( 800 to $1100 \mathrm{cfm}$ ) from $24 \mathrm{ft}$ surface Mix column with air ( 800 to $1100 \mathrm{cfm}$ ) from surface to $24 \mathrm{ft}$

Mix column with air ( 800 to $1100 \mathrm{cfm}$ ) from $24 \mathrm{ft}$ to surface, end mix 


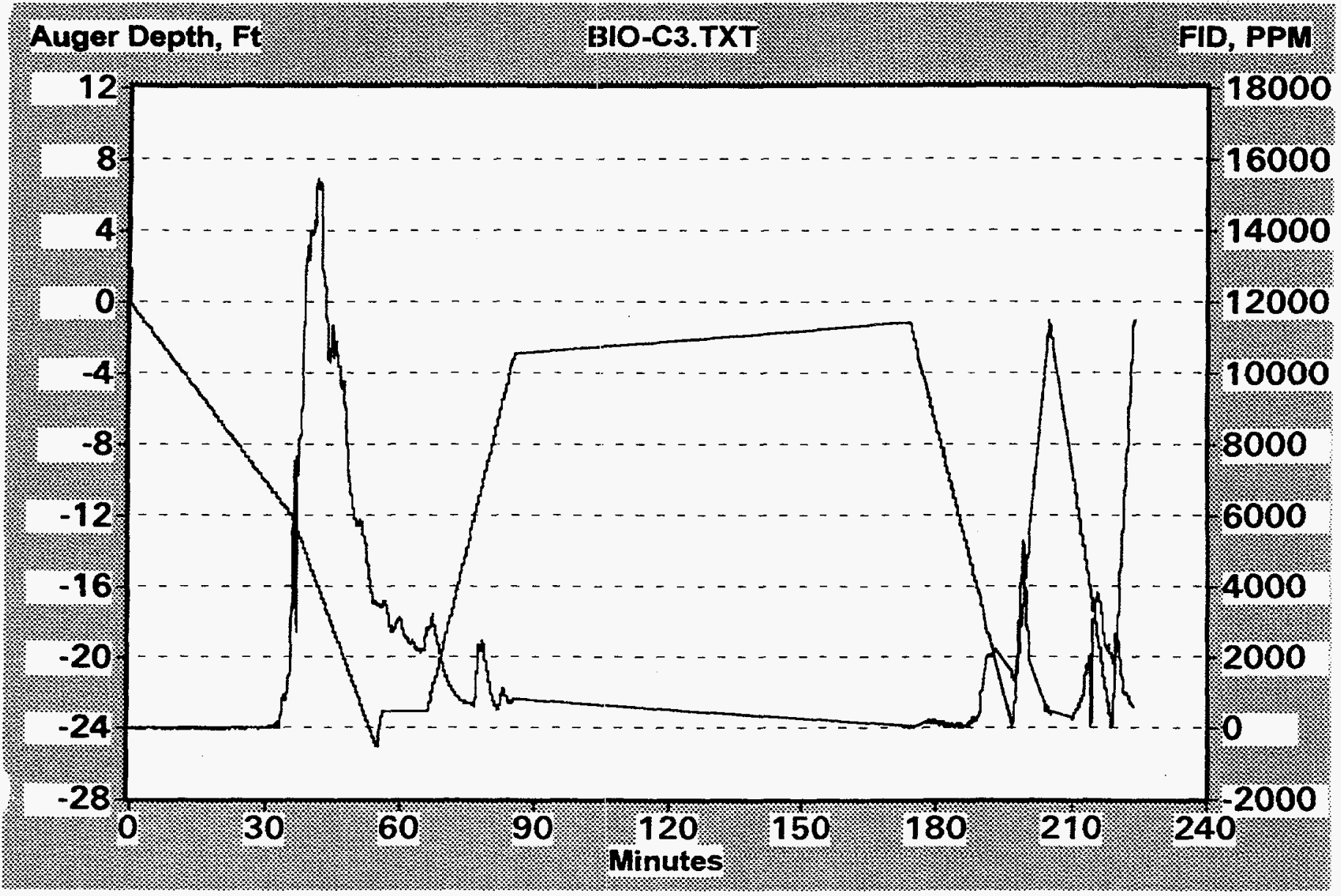


Bio-C2 (T3C2) Summary

Date: 7-11-96

DAS time start: $17: 36: 57=0 \mathrm{~min}$

DAS time stop: $18: 35: 30=58.55 \mathrm{~min}$

Off-gas sample collection for TCE analysis:

Clock time Elapsed time Depth, $\mathrm{ft}$ GC detector FID reading, TCE, ppm $\quad$ ppm

$\begin{array}{llllll}18: 00: 29 & 00: 23.50 & 24 & \text { ECD } & 6700 & 401\end{array}$

$\begin{array}{llllll}18: 23: 20 & 00: 46.38 & 14 & \text { ECD } & 1300 & 148\end{array}$

$\begin{array}{llllll}18: 31: 50 & 00: 54.889 & 8 & \text { ECD } & 2000 & 29\end{array}$

Process Summary:

Elapsed time Process description

0 to $20 \mathrm{~min}$

An 8-ft diameter hole drilled with air (700 to $1000 \mathrm{cfm})$ to a depth of $24 \mathrm{ft}$

20 to $31 \mathrm{~min}$

Prepare for mixing

31 to $38 \mathrm{~min}$

$279 \mathrm{gal}$ of bacteria mix added between $24 \mathrm{ft}$ to surface

38 to $51 \mathrm{~min}$

Mix column with air ( 800 to $1100 \mathrm{cfm}$ ) from surface to $24 \mathrm{ft}$

51 to $57 \mathrm{~min}$ Mix column with air ( 800 to $1100 \mathrm{cfm}$ ) from $24 \mathrm{ft}$ surface

57 to $59 \mathrm{~min}$ Clear ports on auger blade, end mix 


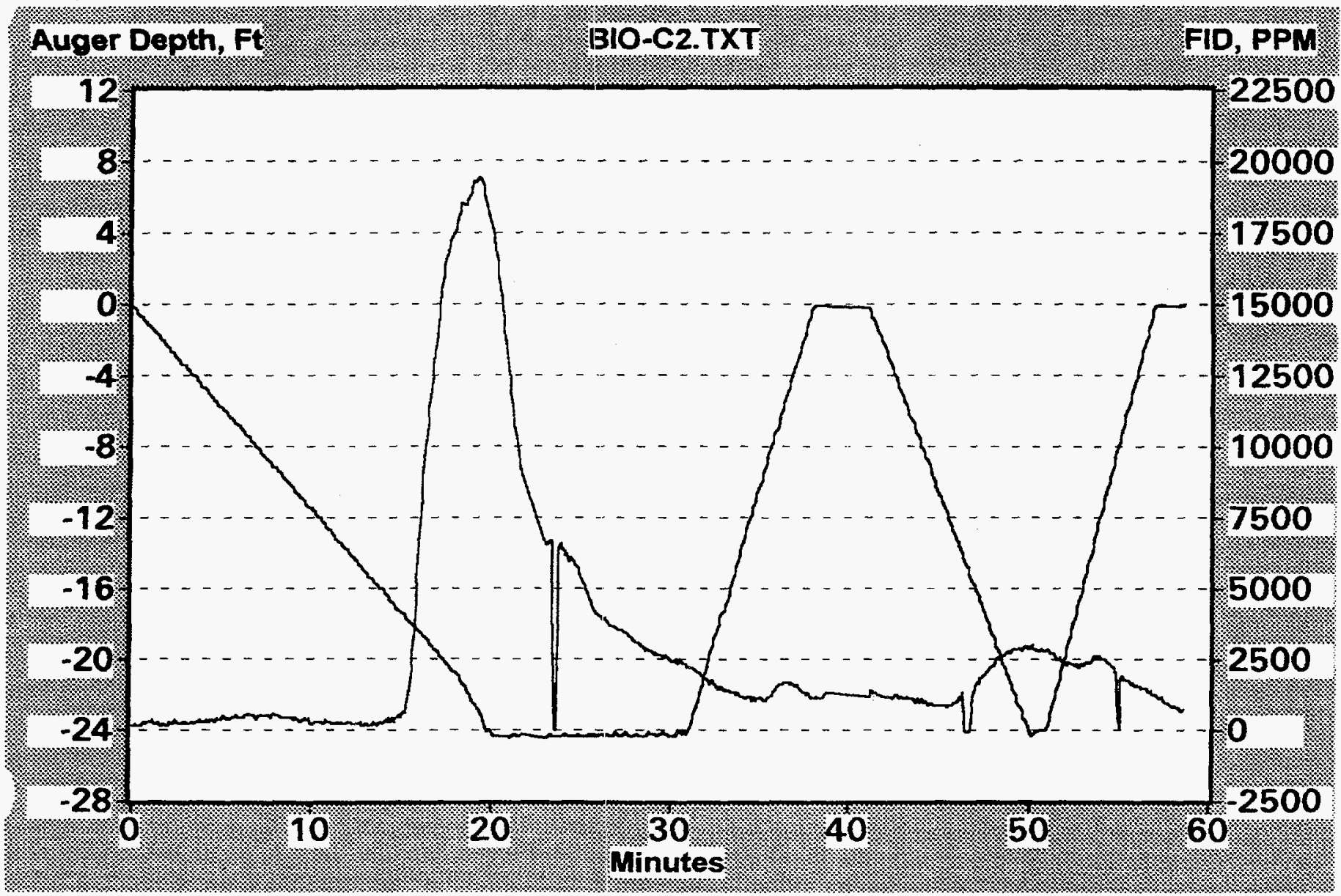




\section{Bio-C1 (T3C1) Summary}

Date: $7-11-96$

DAS time start: $14: 37: 34=0 \mathrm{~min}$

DAS time stop: $17: 31: 02=173.47 \mathrm{~min}$

Off-gas sample collection for TCE analysis:

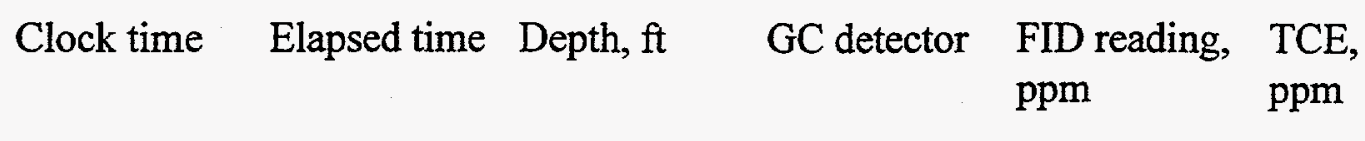

$\begin{array}{llllll}14: 55: 58 & 00: 18: 24 & 10 & \text { ECD } & 4500 & 906\end{array}$

$\begin{array}{llllll}14: 55: 58 & 00: 18: 24 & 10 & \text { FID } & 4500 & 585\end{array}$

$\begin{array}{llllll}15: 10: 34 & 00: 33: 00 & 19 & \text { ECD } & 8000 & 520\end{array}$

$\begin{array}{llllll}15: 10: 34 & 00: 33: 00 & 19 & \text { FID } & 8000 & 385\end{array}$

$\begin{array}{llllll}15: 32: 04 & 00: 54: 30 & 14 & \text { ECD } & 1400 & 64\end{array}$

$\begin{array}{llllll}15: 32: 04 & 00: 54: 30 & 14 & \text { FID } & 1400 & 54\end{array}$

$\begin{array}{llllll}17: 04: 28 & 02: 45: 00 & 8 & \text { ECD } & 1600 & 194\end{array}$

Process Summary:

Elapsed time Process description

0 to $47 \mathrm{~min} \quad$ An 8-ft diameter hole drilled with air $(800$ to $1100 \mathrm{cfm})$ to a depth of $25 \mathrm{ft}$

47 to $64 \mathrm{~min} \quad 266$ gal bacteria mix added and mixed between 23 and $2.5 \mathrm{ft}$

64 to $140 \mathrm{~min} \quad$ Rig repair (shroud seal replaced)

140 to $165 \mathrm{~min} \quad$ Mix column with air $(800$ to $1100 \mathrm{cfm})$ from 1.5 to $23 \mathrm{ft}$

165 to $173 \mathrm{~min} \quad$ Mix column with air $(800$ to $1100 \mathrm{cfm})$ from 23 to $1.5 \mathrm{ft}$, end mixing 


$$
\text { C-6 }
$$

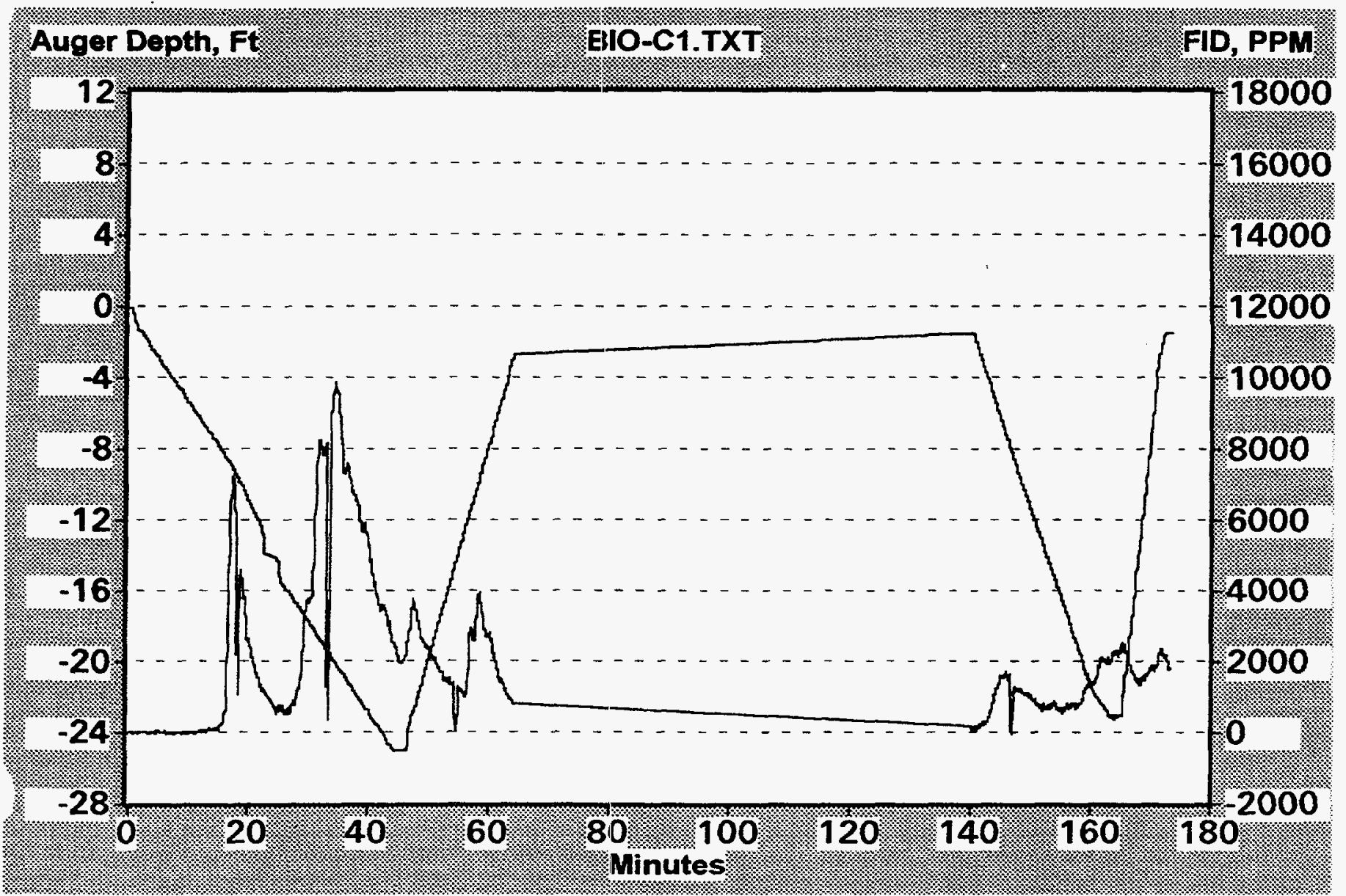




\section{KMnO (T4C1A) Summary}

Note: Because this mix spaned two days, the data is presented in two separate files (T4C1A and $\mathrm{T} 4 \mathrm{C} 1 \mathrm{~B}$ ) to provide better graphic resolution on the plots.

Date: 7-15-96

DAS time start: $14: 49: 39 \mathrm{~min}$

DAS time stop: $16: 05: 35=75.93 \mathrm{~min}$

Off-gas sample collection for TCE analysis:

Clock time Elapsed time Depth, $\mathrm{ft}$ GC detector FID reading, TCE, ppm $\quad$ ppm

$\begin{array}{llllll}15: 09: 38 & 00: 20.15 & 12 & \text { ECD } & 12,000 & 1,112\end{array}$ $\begin{array}{llllll}15: 25: 42 & 00: 36.22 & 35 & \text { ECD } & 12,000 & 656\end{array}$

Process Summary:

Elapsed time Process description

0 to $43 \mathrm{~min}$

An 8-ft diameter hole drilled with air $(700$ to $1000 \mathrm{cfm})$ to a depth of $47 \mathrm{ft}$

43 to $66 \mathrm{~min}$ $1880 \mathrm{gal} \mathrm{KMnO}_{4}$ mixed from 47 to $10 \mathrm{ft}(51 \mathrm{gal} / \mathrm{ft})$

66 to $76 \mathrm{~min}$ Lift auger to surface, blow out ports with air, end of day 


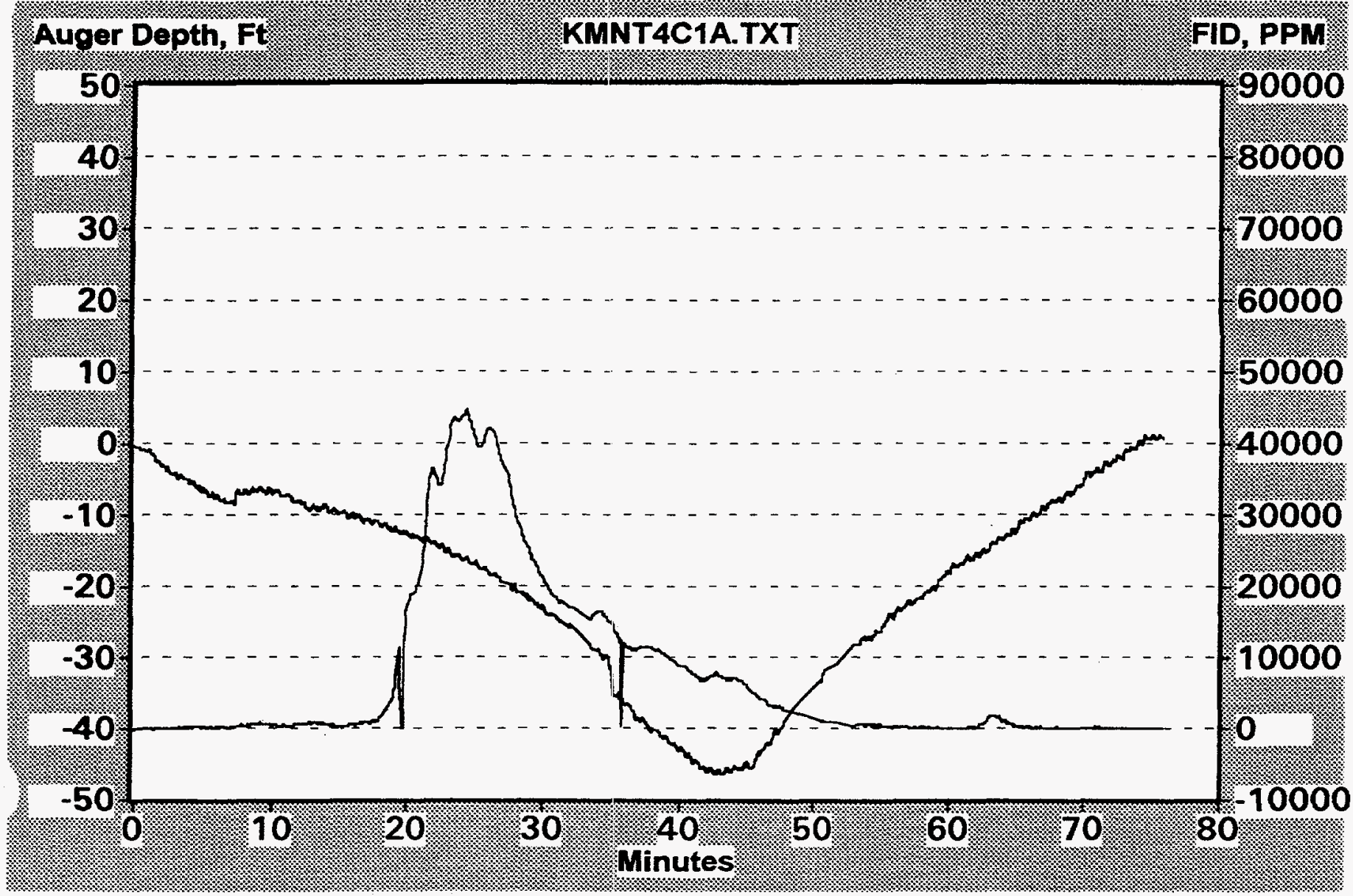




\section{C-9}

\section{KMnO (T4C1B) Summary}

Note: Because this mix spaned two days, the data is presented in two separate files ( $\mathrm{T} 4 \mathrm{C} 1 \mathrm{~A}$ and $\mathrm{T} 4 \mathrm{C} 1 \mathrm{~B}$ ) to provide better graphic resolution on the plots.

Date: 7-16-96

DAS time start: $08: 26: 53=0 \mathrm{~min}$

DAS time stop: $10: 41: 41=134.8 \mathrm{~min}$

Off-gas sample collection for TCE analysis:

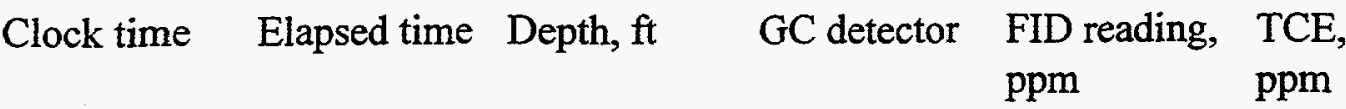

No off-gas samples collected.

Process Summary:

Elapsed time

0 to $17 \mathrm{~min}$

17 to $41 \mathrm{~min}$

41 to $58 \mathrm{~min}$

58 to $62 \mathrm{~min}$

62 to $97 \mathrm{~min}$

97 to $135 \mathrm{~min}$
Process description

Drill from surface to $10 \mathrm{ft}$

$782 \mathrm{gal} \mathrm{KMnO}_{4}$ mixed from $10 \mathrm{ft}$ to $47 \mathrm{ft}(21 \mathrm{gal} / \mathrm{ft})$

816 gal $\mathrm{KMnO}_{4}$ mixed from 47 to $10 \mathrm{ft}(22 \mathrm{gal} / \mathrm{ft})$

Rotate out to surface, $\mathrm{KMnO}_{4}$ flowing out under shroud Drill from surface to $47 \mathrm{ft}$ with no air or fluid injection Rotate from $47 \mathrm{ft}$ to surface with no air or fluid injection, end of $\mathrm{mix}$ 


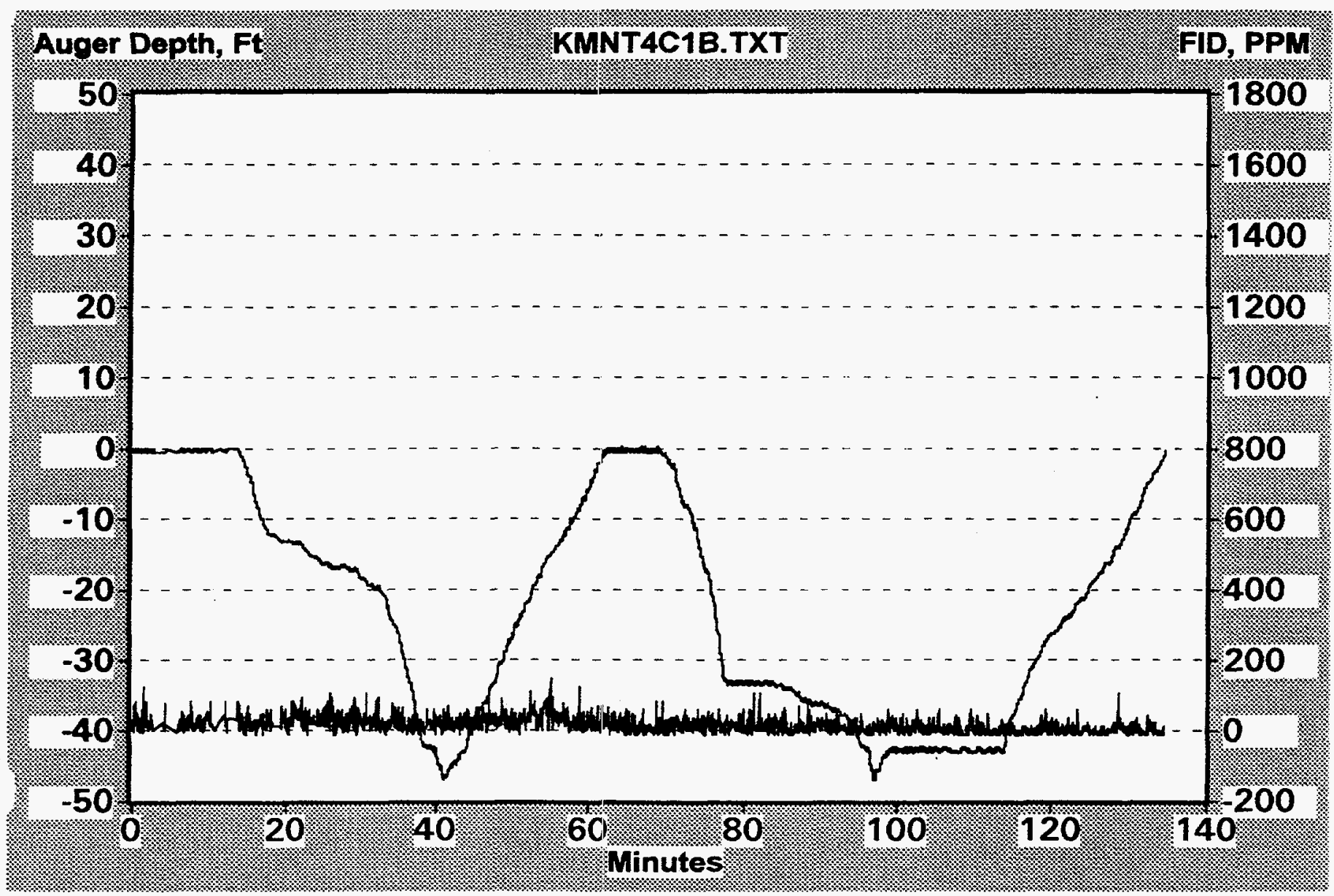


KMnO (T4C2) Summary

Date: $7-16-96$

DAS time start: $15: 56: 56=0 \mathrm{~min}$

DAS time stop: $18: 11: 31=134.63 \mathrm{~min}$

Off-gas sample collection for TCE analysis:

Clock time Elapsed time Depth, ft GC detector FID reading, TCE, ppm ppm

$\begin{array}{llllll}16: 24: 39 & 00: 27.7 & 21 & \text { ECD } & 22,000 & 1,416 \\ 16: 26: 43 & 00: 29.83 & 24 & \text { ECD } & 13,000 & 1,093 \\ 16: 38: 13 & 00: 41.33 & 42 & \text { ECD } & 2,200 & 215\end{array}$

Process Summary:

Elapsed time Process description

0 to $44 \mathrm{~min}$

An 8-ft diameter hole drilled with air (700 to $1000 \mathrm{cfm}$ ) to a depth of $47 \mathrm{ft}$

44 to $58 \mathrm{~min} \quad 1206 \mathrm{gal} \mathrm{KMnO}_{4}$ mixed in between 47 and $10 \mathrm{ft}$ $(32.6 \mathrm{gal} / \mathrm{ft})$

58 to $68 \mathrm{~min} \quad$ Rotate out from $10 \mathrm{ft}$ to $4 \mathrm{ft}, 1200$ gal $\mathrm{H}_{2} \mathrm{O}$ added to $\mathrm{KmnO}_{4}$ mixing tank

68 to $71 \mathrm{~min}$ Rotate from $4 \mathrm{ft}$ to $10 \mathrm{ft}$

71 to $88 \mathrm{~min}$ $1162 \mathrm{gal} \mathrm{KMnO}_{4}$ mixed in between $10 \mathrm{ft}$ and $47 \mathrm{ft}$ (31 gal/ft)

88 to $100 \mathrm{~min}$ $300 \mathrm{gal} \mathrm{KMnO}_{4}$ mixed in between 47 and $10 \mathrm{ft}(8 \mathrm{gal} / \mathrm{ft})$

100 to $103 \mathrm{~min}$

103 to $112 \mathrm{~min}$ Rotate out to $7 \mathrm{ft}, 500$ gal $\mathrm{H}_{2} \mathrm{O}$ added to $\mathrm{KMnO}_{4}$ mixing tank

112 to $128 \mathrm{~min}$ $420 \mathrm{gal} \mathrm{KMnO}_{4}$ mixed in between 7 and $47 \mathrm{ft}(10.5 \mathrm{gal} / \mathrm{ft})$ Rotate out from $47 \mathrm{ft}$ to surface with no air or fluid injection

128 to $135 \mathrm{~min}$ Clean out ports with air pressure, end of mix ( $3088 \mathrm{gal}$ total $\mathrm{KMnO}_{4}$ added) 


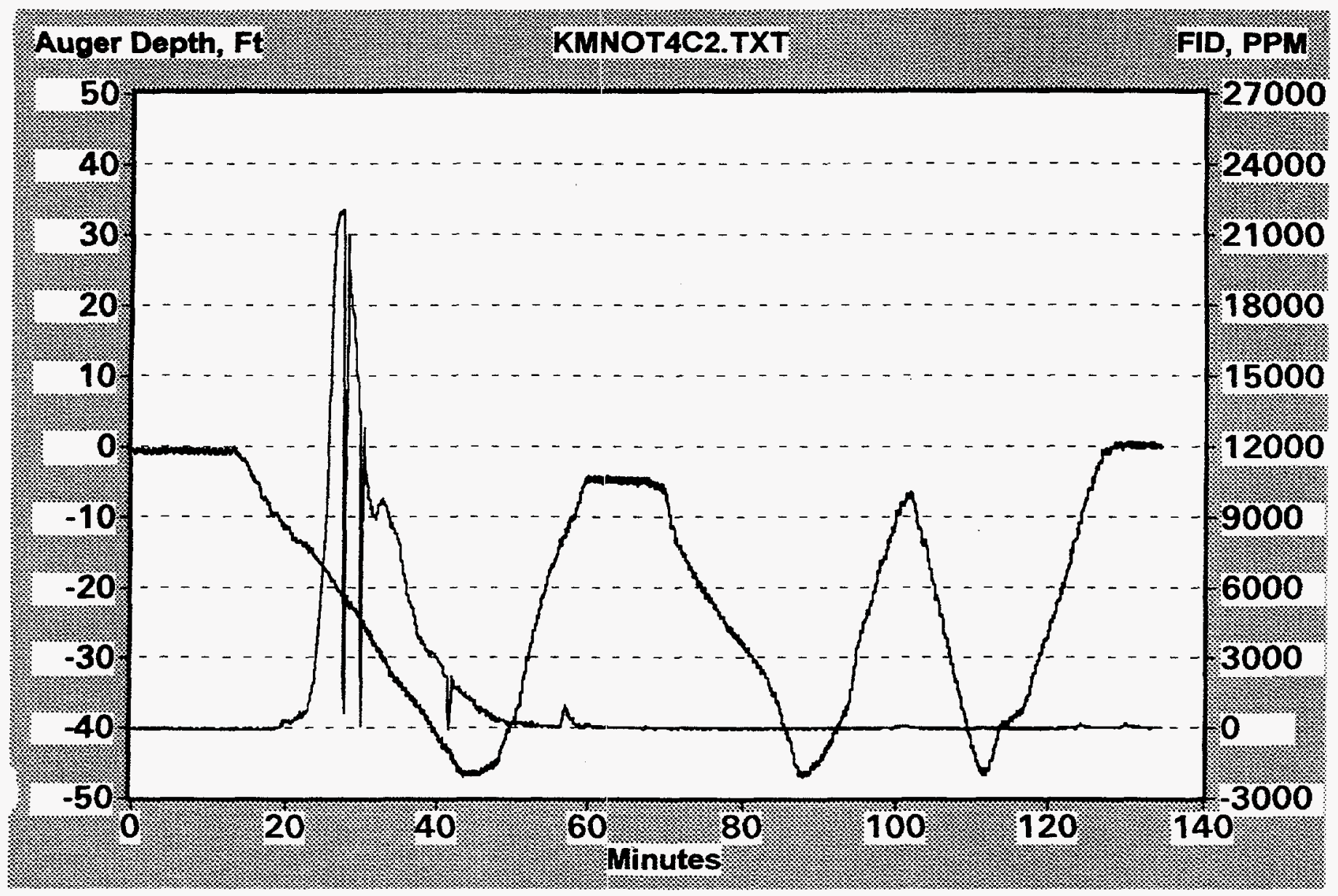




\section{KMnO (T4C3) Summary}

Date: 7-15-96

DAS time start: 09:51:01 $=0 \mathrm{~min}$

DAS time stop: $12: 51: 20=180.32 \mathrm{~min}$

Off-gas sample collection for TCE analysis:

Clock time Elapsed time Depth, $\mathrm{ft}$ GC detector FID reading, TCE, ppm ppm

No off-gas samples were collected from T4C3.

Process Summary:

Elapsed time

Process description

0 to $46 \mathrm{~min}$

An 8-ft diameter hole drilled with air (700 to $1000 \mathrm{cfm})$ to a depth of $47 \mathrm{ft}$

46 to $77 \mathrm{~min}$ 1330 gal $\mathrm{KMnO}_{4}$ mixed in between 47 and $14 \mathrm{ft}(40 \mathrm{gal} / \mathrm{ft})$

77 to $96 \mathrm{~min}$ $627 \mathrm{gal} \mathrm{KMnO}_{4}$ mixed in between $14 \mathrm{ft}$ and $47 \mathrm{ft}(19 \mathrm{gal} / \mathrm{ft})$

96 to $100 \mathrm{~min}$ 849 gal $\mathrm{KMnO}_{4}$ mixed in between $47 \mathrm{ft}$ and $33 \mathrm{ft}$ (60.6 gal ft)

100 to $125 \mathrm{~min}$ Rotate out from $33 \mathrm{ft}$ to surface with no injection of fluid or air

125 to $139 \mathrm{~min}$

139 to $161 \mathrm{~min}$ $977 \mathrm{gal} \mathrm{KMnO}_{4}$ mixed in between $10 \mathrm{ft}$ and $47 \mathrm{ft}$ (26 gal/ft), 630 gal $\mathrm{H}_{2} \mathrm{O}$ added to tank to increase volume $298 \mathrm{gal} \mathrm{KMnO}_{4}$ mixed in between $47 \mathrm{ft}$ and $10 \mathrm{ft}(8 \mathrm{gal} / \mathrm{ft})$

161 to $169 \mathrm{~min}$ $570 \mathrm{gal} \mathrm{KMnO}_{4}$ mixed in between $10 \mathrm{ft}$ and $47 \mathrm{ft}(15 \mathrm{gal} / \mathrm{ft})$ 169 to $180 \mathrm{~min}$ Rotate out from $47 \mathrm{ft}$ to surface with no fluid or air injection, end of mix, (4651 gal total $\mathrm{KMnO}_{4}$ injected) 


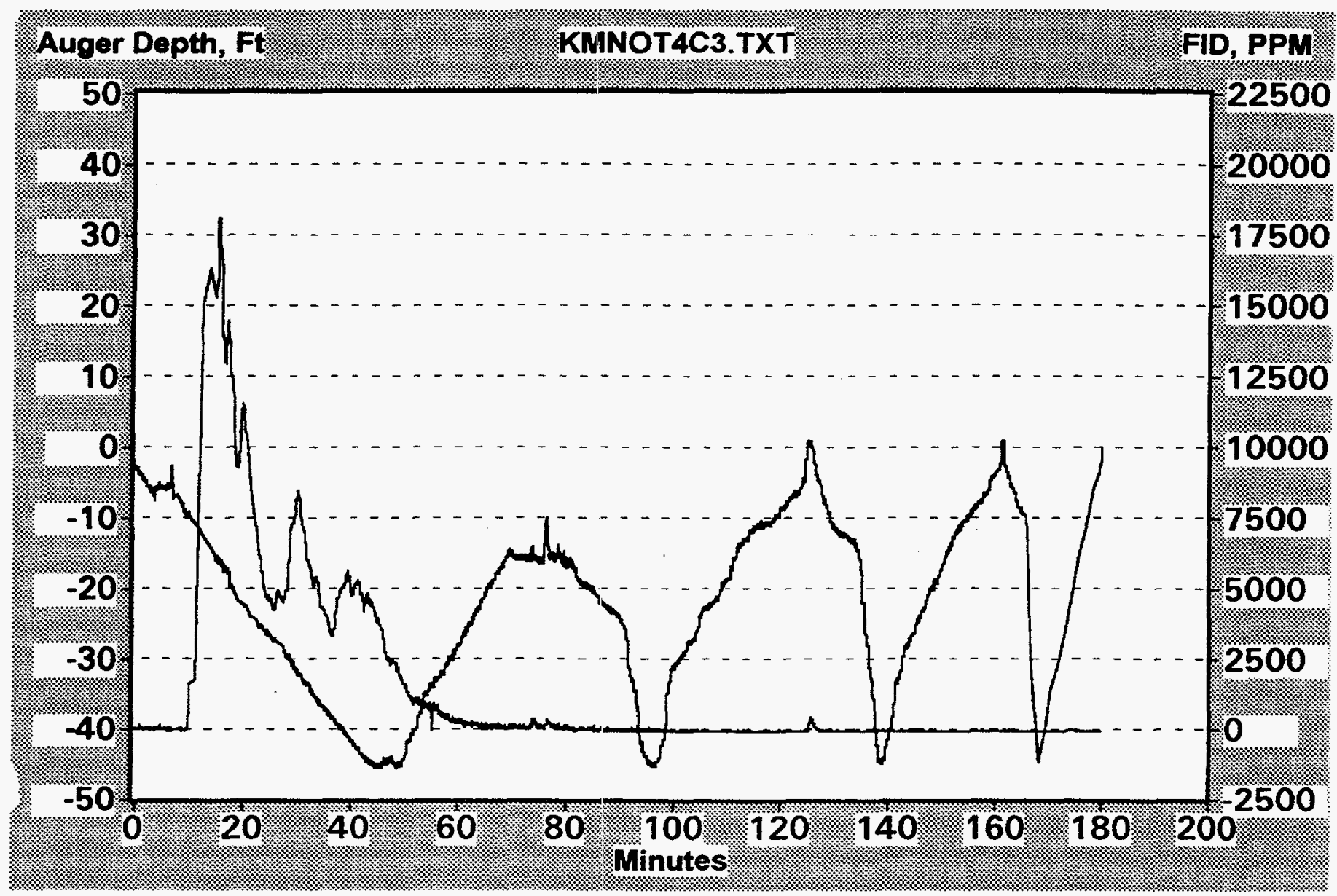




\section{C-15}

\section{KMnO (T5C1) Summary}

Date: 7-13-96

DAS time start: $10: 59: 26=0 \mathrm{~min}$

DAS time stop: $13: 09: 14=129.8 \mathrm{~min}$

Off-gas sample collection for TCE analysis:

Clock time Elapsed time Depth, $\mathrm{ft}$ GC detector FID reading, TCE, ppm $\quad \mathrm{ppm}$

$\begin{array}{lllllll}11: 25: 21 & 00: 25.92 & 14 & \text { ECD } & 13,000 & 948\end{array}$

$\begin{array}{llllll}11: 25: 21 & 00: 25.92 & 14 & \text { FID } & 13,000 & 963\end{array}$

$\begin{array}{llllll}11: 31: 17 & 00: 31.85 & 21 & \text { ECD } & 15,000 & 620\end{array}$

$\begin{array}{llllll}11: 31: 17 & 00: 31.85 & 21 & \text { FID } & 15,000 & 491\end{array}$

Process Summary:

Elapsed time

0 to $14 \mathrm{~min}$

14 to $19 \mathrm{~min}$ 19 to $36 \mathrm{~min}$ 36 to $44 \mathrm{~min}$ 44 to $55 \mathrm{~min}$ 55 to $62 \mathrm{~min}$ 62 to $75 \mathrm{~min}$ 75 to $91 \mathrm{~min}$ 91 to $97 \mathrm{~min}$ 97 to $99 \mathrm{~min}$ 99 to $112 \mathrm{~min}$ 112 to $118 \mathrm{~min}$ 118 to $121 \mathrm{~min}$
Process description

An 8-ft diameter hole drilled with air (700 to $1000 \mathrm{cfm}$ ) to a depth of $10 \mathrm{ft}$

Rotate to surface for repair

Drill from surface to $25 \mathrm{ft}$ with air $(700$ to $1000 \mathrm{cfm})$

$560 \mathrm{gal} \mathrm{KMnO}_{4}$ mixed from 24 to $10 \mathrm{ft}$

Rotate to surface for repairs

Complete repairs

Drill with air from surface to $10 \mathrm{ft}$

$625 \mathrm{gal} \mathrm{KMnO}_{4}$ mixed in from $10 \mathrm{ft}$ to $25 \mathrm{ft}(40 \mathrm{gal} / \mathrm{ft})$

$705 \mathrm{gal} \mathrm{KMnO}_{4}$ mixed in from $24 \mathrm{ft}$ to $10 \mathrm{ft}(50 \mathrm{gal} / \mathrm{ft})$

Rotate from $10 \mathrm{ft}$ to $3 \mathrm{ft}$

Rotate from $3 \mathrm{ft}$ to $25 \mathrm{ft}$, add 64 gal $\mathrm{KMnO}_{4}$ at $25 \mathrm{ft}$

Rotate from $25 \mathrm{ft}$ to surface with no air or fluid injection Lift auger above ground and clear ports with air pressure, end mix 


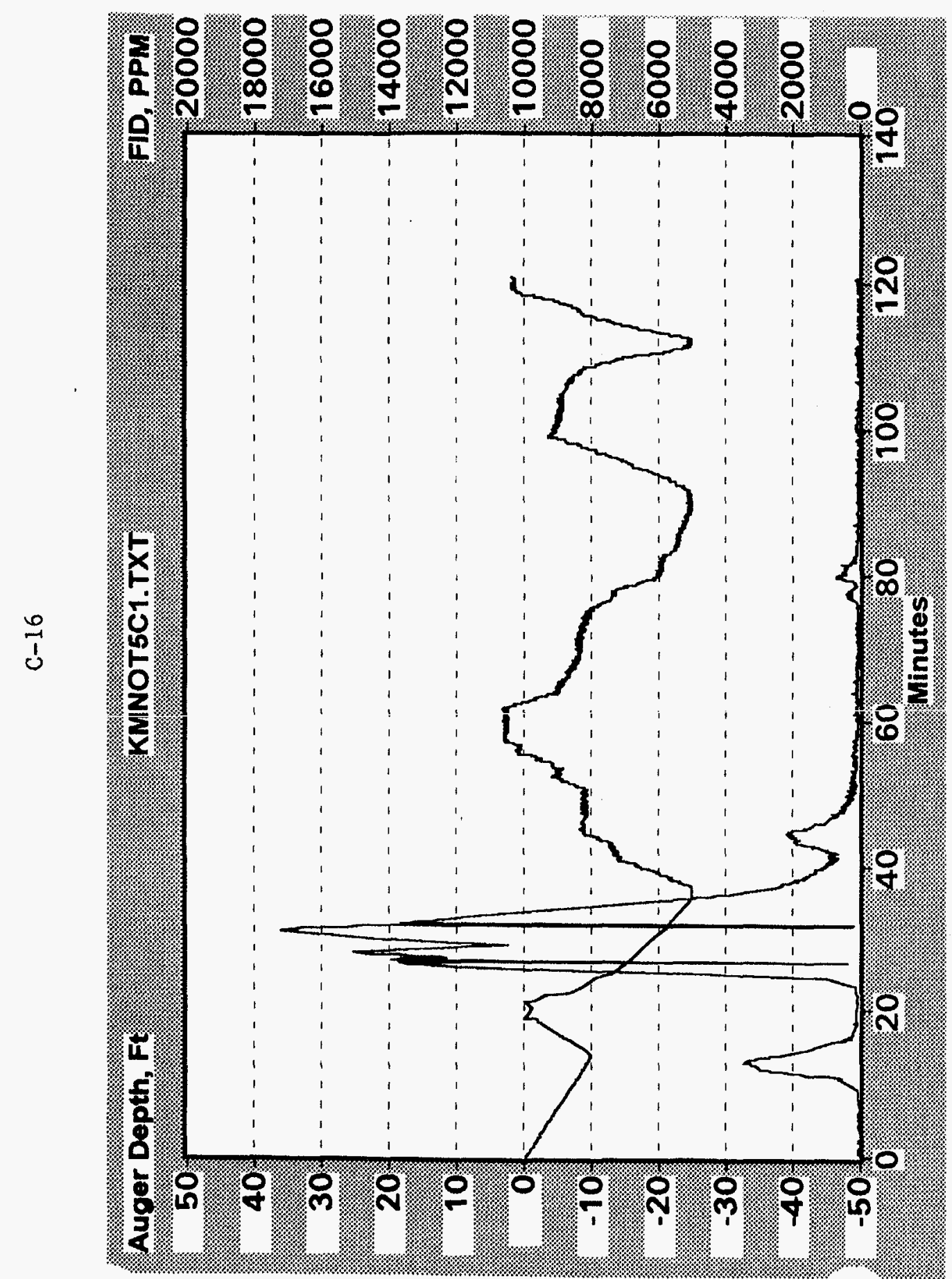


KMnO (T5C2) Summary

Date: 7-13-96

DAS time start: $14: 26: 46=0 \mathrm{~min}$

DAS time stop: $15: 29: 26=62.67 \mathrm{~min}$

Off-gas sample collection for TCE analysis:

Clock time Elapsed time Depth, $\mathrm{ft}$ GC detector FID reading, TCE, ppm ppm

$\begin{array}{llllll}14: 39: 21 & 00: 12.58 & 13 & \text { FID } & 6,400 & 539\end{array}$

$\begin{array}{llllll}14: 42: 56 & 00: 16.17 & 11 & \text { FID } & 15,000 & 286\end{array}$

Process Summary:

Elapsed time Process description

0 to $4 \mathrm{~min}$

Prepare for drilling

4 to $27 \mathrm{~min}$

An 8-ft diameter hole drilled with air (700 to $1000 \mathrm{cfm}$ ) to a depth of $25 \mathrm{ft}$

27 to $35 \mathrm{~min}$ $570 \mathrm{gal} \mathrm{KMnO}_{4}$ mixed in between 24 and $10 \mathrm{ft}$ 35 to $45 \mathrm{~min}$ $556 \mathrm{gal} \mathrm{KMnO} \mathrm{KM}_{4}$ mixed in between 10 and $23 \mathrm{ft}$ 45 to $50 \mathrm{~min}$ Rotate from $23 \mathrm{ft}$ to $8 \mathrm{ft}$ with no air or fluid injection 50 to $52 \mathrm{~min}$ Rotate from $8 \mathrm{ft}$ to $23 \mathrm{ft}$ with no air or fluid injection 52 to $59 \mathrm{~min}$ Rotate from 23 to surface with no air or fluid injection 59 to $63 \mathrm{~min}$ Lift auger above ground and clear ports with air pressure, end mix 


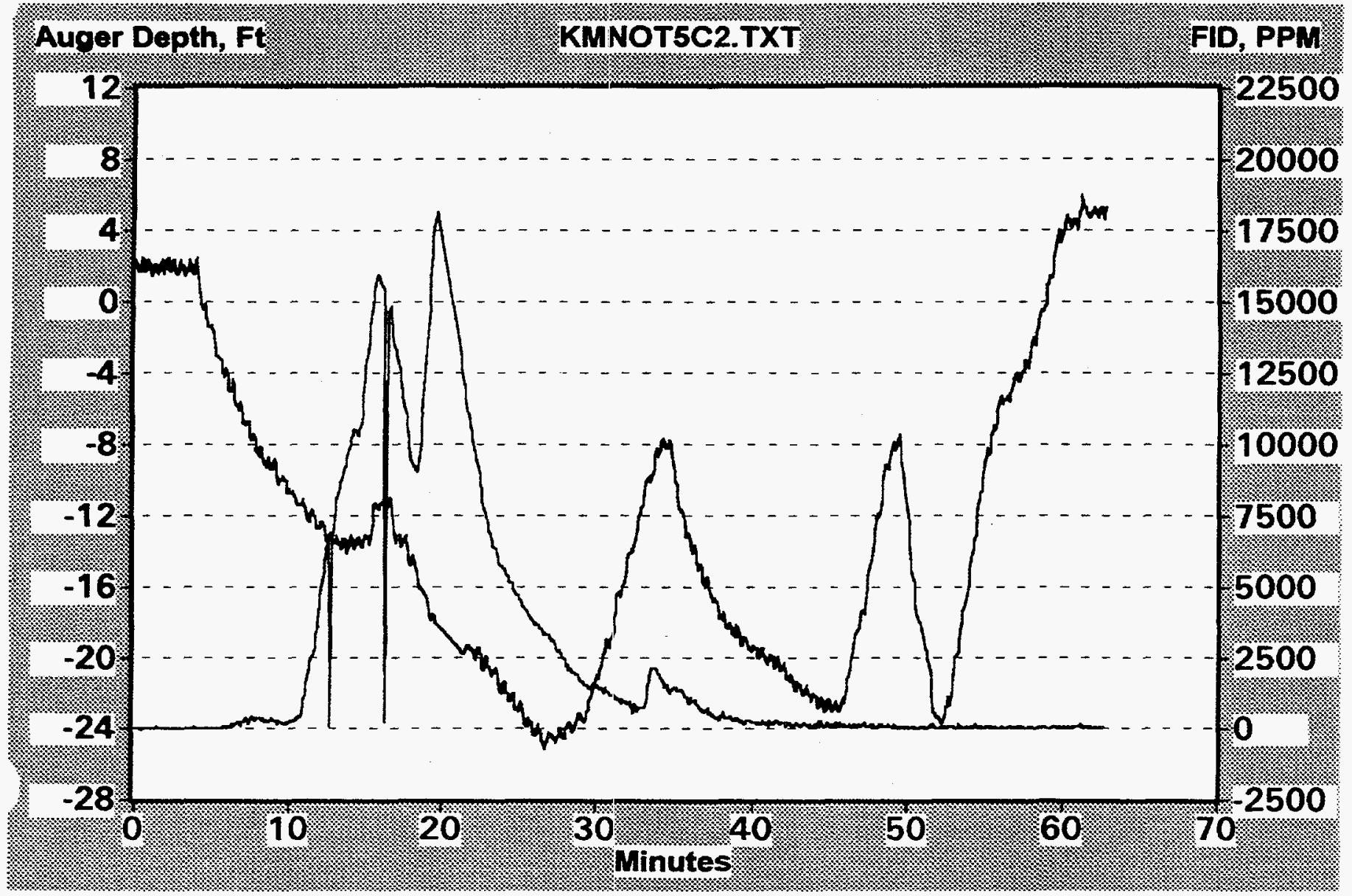




\section{KMnO (T5C3) Summary}

Date: $7-12-96$

DAS time start: $16: 50: 27=0 \mathrm{~min}$

DAS time stop: $18: 15: 00=84.55 \mathrm{~min}$

Off-gas sample collection for TCE analysis:

Clock time Elapsed time Depth, $\mathrm{ft} \quad$ GC detector $\begin{aligned} & \begin{array}{l}\text { FID reading, } \\ \mathrm{ppm}\end{array} \\ & \begin{array}{l}\mathrm{TCE} \\ \mathrm{ppm}\end{array}\end{aligned}$

$\begin{array}{llllll}17: 10: 51 & 00: 20.40 & 23 & \text { ECD } & 8000 & 52 \\ 17 \cdot 26: 11 & 00 \cdot 35.73 & 5 & \text { ECD } & 1200 & 11\end{array}$

Process Summary:

Elapsed time

Process description

0 to $21 \mathrm{~min}$

An 8-ft diameter hole drilled with air (700 to $1000 \mathrm{cfm})$ to a depth of $25 \mathrm{ft}$

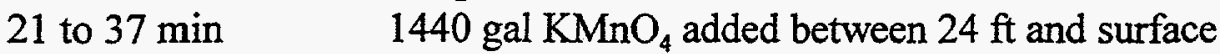
(60 gal $/ \mathrm{ft})$

37 to $53 \mathrm{~min}$ 1263 gal $\mathrm{KMnO}_{4}$ added between surface and $24 \mathrm{ft}$ (40 gal/ft)

53 to $60 \mathrm{~min}$ Mix column with no air or fluid from $24 \mathrm{ft}$ to surface 60 to $67 \mathrm{~min}$ Drill from surface to $10 \mathrm{ft}$ with air (800 to $1000 \mathrm{cfm})$

67 to $80 \mathrm{~min}$ 1000 gal $\mathrm{KMnO}_{4}$ added between $10 \mathrm{ft}$ and $24 \mathrm{ft}$ 80 to $85 \mathrm{~min}$ Rotate out from $24 \mathrm{ft}$ to surface with no air or fluid, end $\operatorname{mix}$ 


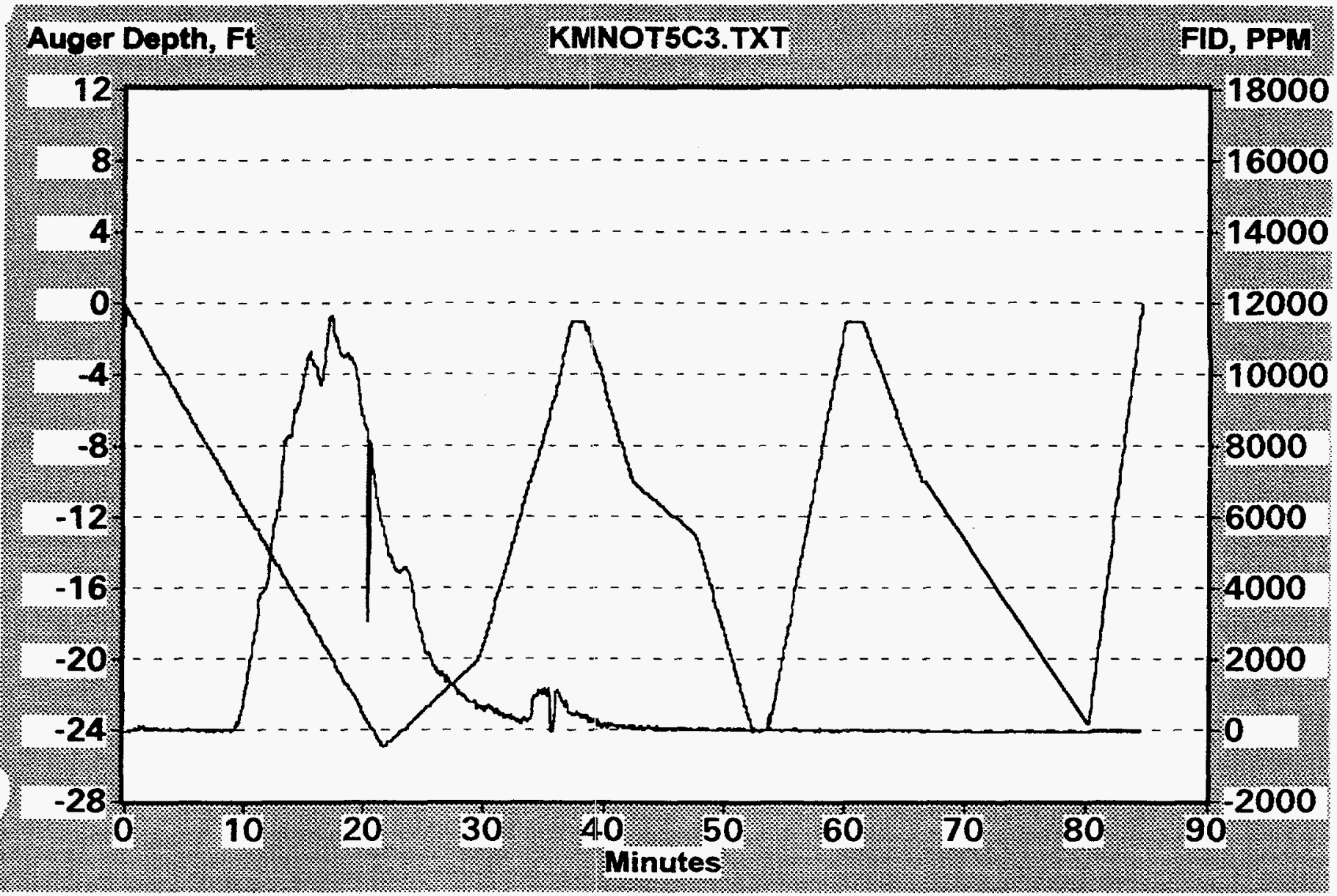




\section{Air T7C1 Summary}

Date: $7-20-96$

DAS time start: 08:55:43 $=0 \mathrm{~min}$

DAS time stop: $11: 27: 24=151.68 \mathrm{~min}$

Off-gas sample collection for TCE analysis:

$\begin{array}{llll}\text { Clock time Elapsed time Depth, ft GC detector } & \begin{array}{l}\text { FID reading, } \\ \text { ppm }\end{array} & \begin{array}{l}\text { TCE, } \\ \text { ppm }\end{array}\end{array}$

$\begin{array}{llllll}10: 11: 01 & 00: 75.30 & 18 & \text { ECD } & 1700 & 12\end{array}$

Process Summary:

Elapsed time Process description

0 to $9 \mathrm{~min}$

9 to $44 \mathrm{~min}$

Prepare for drilling

An 8-ft diameter hole drilled with air (1500 to $1700 \mathrm{cfm})$ to a depth of $25 \mathrm{ft}$

44 to $55 \mathrm{~min}$

55 to $81 \mathrm{~min}$

Mix with air $(1700 \mathrm{cfm})$ from $25 \mathrm{ft}$ to $1 \mathrm{ft}$

81 to $87 \mathrm{~min}$

Mix with air $(1700 \mathrm{cfm})$ from $1 \mathrm{ft}$ to $25 \mathrm{ft}$

Mix column with air $(1700 \mathrm{cfm})$ from $25 \mathrm{ft}$ to $1 \mathrm{ft}$

87 to $108 \mathrm{~min}$

Mix column with air $(1700 \mathrm{cfm})$ from $1 \mathrm{ft}$ to $25 \mathrm{ft}$

108 to $114 \mathrm{~min}$

114 to $131 \mathrm{~min}$

Mix column with air $(1700 \mathrm{cfm})$ from $25 \mathrm{ft}$ to $1 \mathrm{ft}$ Mix column with air $(1700 \mathrm{cfm})$ from $1 \mathrm{ft}$ to $25 \mathrm{ft}$

131 to $138 \mathrm{~min}$ Mix column with air $(1700 \mathrm{cfm})$ from $25 \mathrm{ft}$ to $1 \mathrm{ft}$

138 to $152 \mathrm{~min}$

Raise auger, blow out ports with air, end of mix 


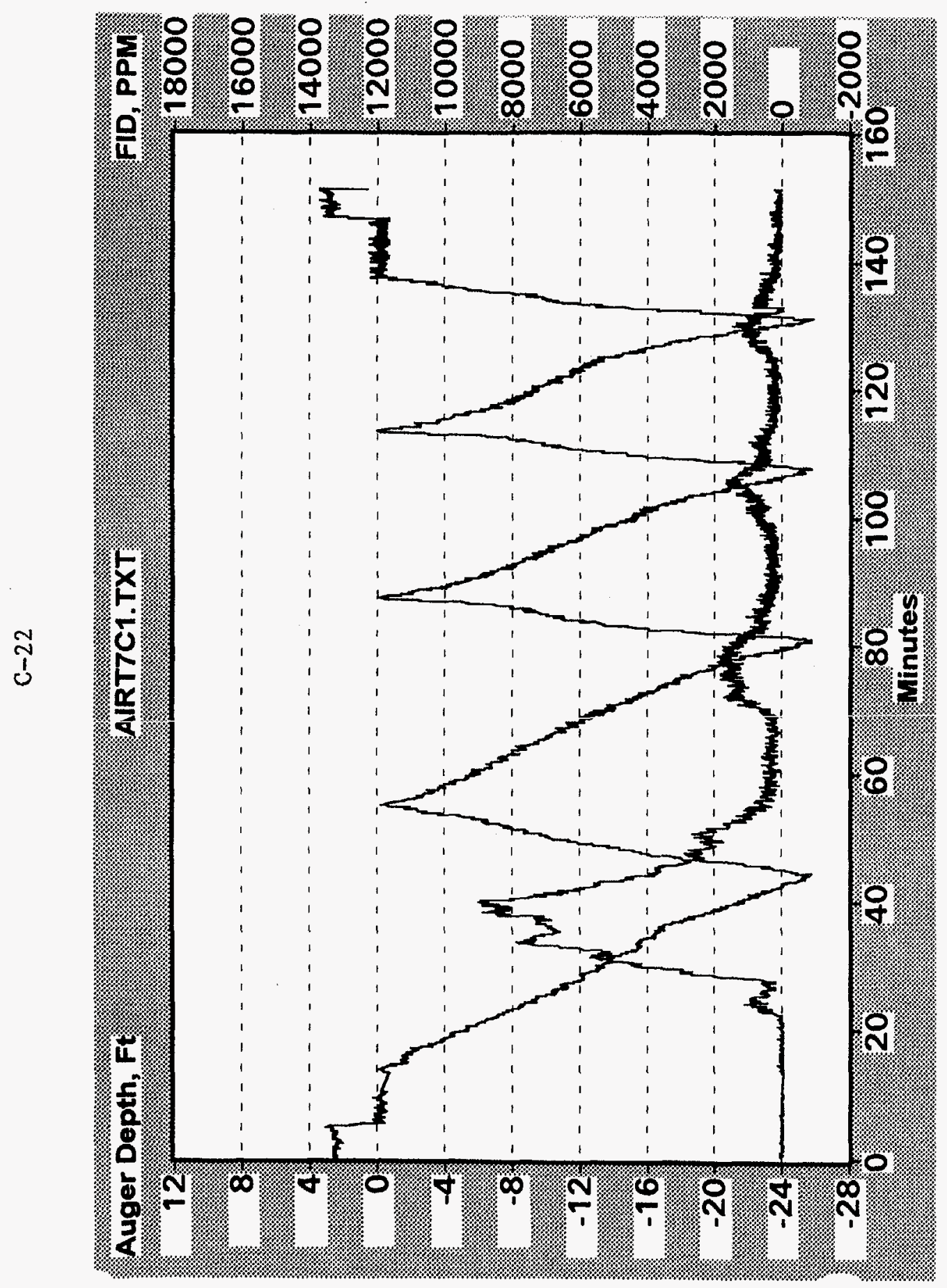




\section{Air T7C2 Summary}

Date: $7-20-96$

DAS time start: $11: 29: 39=0 \mathrm{~min}$

DAS time stop: $15: 20: 04=230.42 \mathrm{~min}$

Off-gas sample collection for TCE analysis:

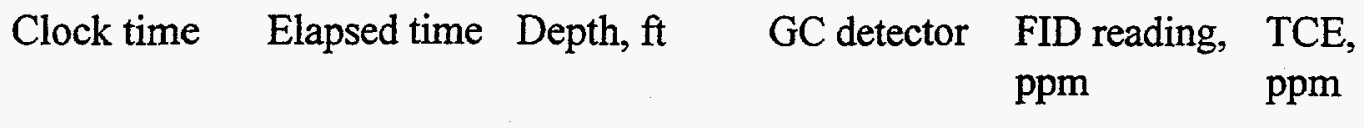

$\begin{array}{llllll}14: 55: 55 & 03: 44.00 & 20 & \text { ECD } & 600 & 12\end{array}$

Process Summary:

Elapsed time

Process description

0 to $20 \mathrm{~min}$

An 8-ft diameter hole drilled with air (1500 to $1700 \mathrm{cfm}$ ) to a depth of $25 \mathrm{ft}$

20 to $27 \mathrm{~min}$

27 to $108 \mathrm{~min}$

Mix with air $(1700 \mathrm{cfm})$ from $25 \mathrm{ft}$ to $1 \mathrm{ft}$

108 to $133 \mathrm{~min}$

Break for lunch and minor rig repairs

133 to $151 \mathrm{~min}$

Mix with air $(1700 \mathrm{cfm})$ from $1 \mathrm{ft}$ to $25 \mathrm{ft}$

151 to $173 \mathrm{~min}$

Mix column with air $(1700 \mathrm{cfm})$ from $25 \mathrm{ft}$ to $1 \mathrm{ft}$

Mix column with air $(1700 \mathrm{cfm})$ from $1 \mathrm{ft}$ to $25 \mathrm{ft}$

173 to $188 \mathrm{~min}$

Mix column with air $(1700 \mathrm{cfm})$ from $25 \mathrm{ft}$ to $1 \mathrm{ft}$

188 to $211 \mathrm{~min}$ Mix column with air $(1700 \mathrm{cfm})$ from $1 \mathrm{ft}$ to $25 \mathrm{ft}$

211 to $230 \mathrm{~min}$

Mix column with air $(1700 \mathrm{cfm})$ from $25 \mathrm{ft}$ to $1 \mathrm{ft}$, end of $\operatorname{mix}$ 


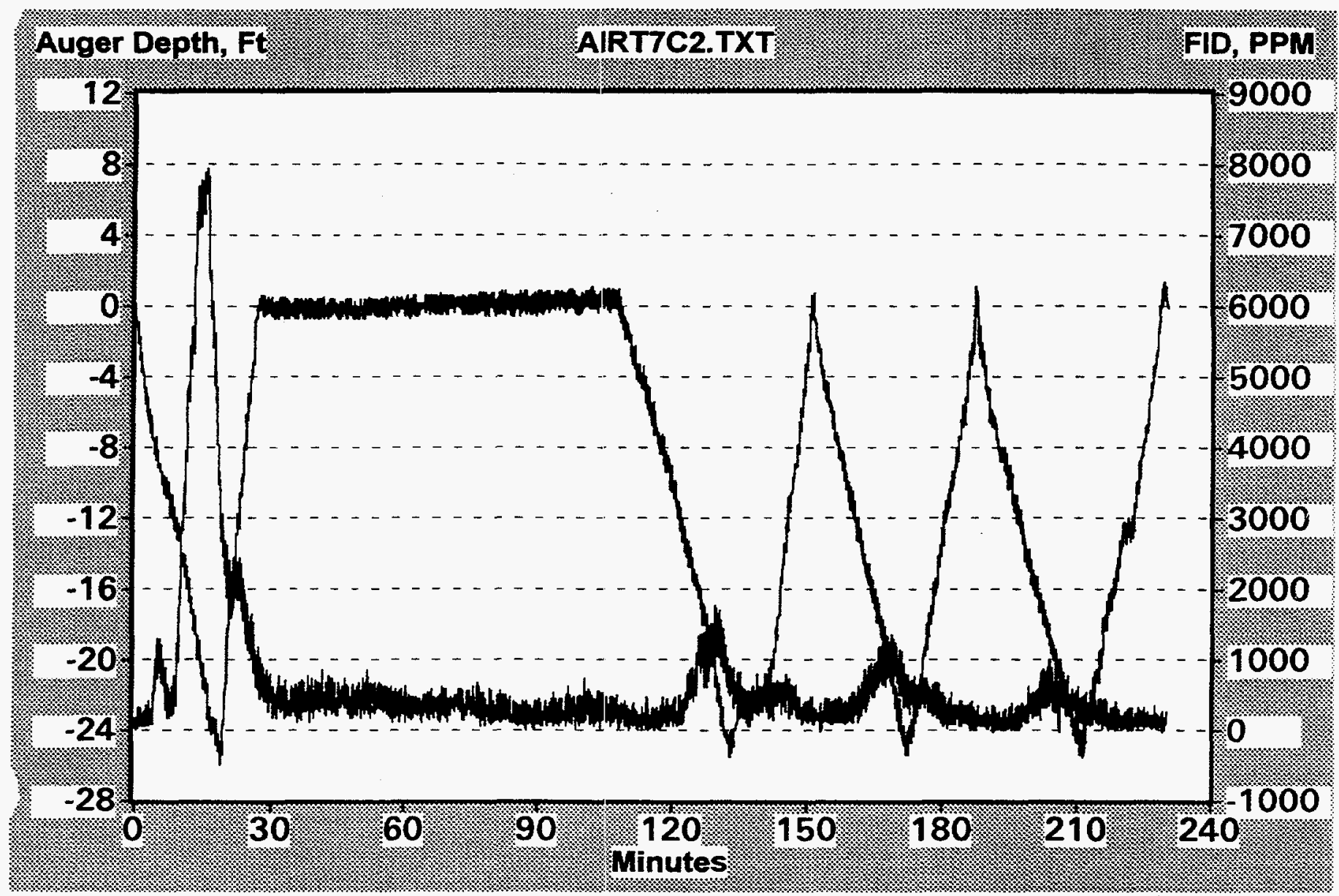




\section{Air T7C3 Summary}

Date: 7-19-96

DAS time start: 09:06:11 $=0 \mathrm{~min}$

DAS time stop: $16: 46: 23=460.2 \mathrm{~min}$

Off-gas sample collection for TCE analysis:

Clock time Elapsed time Depth, $\mathrm{ft}$ GC detector FID reading, TCE, ppm $\quad$ ppm

No off-gas vapor sample collected.

Process Summary:

Elapsed time

Process description

0 to $20 \mathrm{~min}$

An 8-ft diameter hole drilled with air (1500 to $1700 \mathrm{cfm})$ to a depth of $25 \mathrm{ft}$

20 to $51 \mathrm{~min}$

Attempt lime from 25 to $22 \mathrm{ft}$ but cannot overcome backpressure, no lime delivered

51 to $71 \mathrm{~min}$

Mix with air $(1700 \mathrm{cfm})$ from $22 \mathrm{ft}$ to surface

71 to $82 \mathrm{~min}$

Reconfigure air lines to maximize pressure throughout lime delivery system

82 to $89 \mathrm{~min}$

Attempt lime delivery from surface to $4 \mathrm{ft}$, cannot

89 to $257 \mathrm{~min}$ overcome backpressure, pull auger to surface Change port size from $0.5 \mathrm{in}$. to $1 \mathrm{in}$. to reduce backpressure

257 to $277 \mathrm{~min} \quad$ Attempt lime delivery from surface to $7 \mathrm{ft}$, cannot overcome backpressure pull auger to surface

277 to $348 \mathrm{~min}$ Change port size back to $0.5 \mathrm{in}$. and air strip the cell 348 to $369 \mathrm{~min}$ Mix column with air $(1700 \mathrm{cfm})$ from surface to $25 \mathrm{ft}$ 369 to $388 \mathrm{~min}$ 388 to $416 \mathrm{~min}$ 416 to $427 \mathrm{~min}$ Mix column with air $(1700 \mathrm{cfm})$ from $25 \mathrm{ft}$ to $1 \mathrm{ft}$ Mix column with air $(1700 \mathrm{cfm})$ from $1 \mathrm{ft}$ to $25 \mathrm{ft}$ Mix column with air $(1700 \mathrm{cfm})$ from $25 \mathrm{ft}$ to $1 \mathrm{ft}$ 427 to $448 \mathrm{~min}$ Mix column with air $(1700 \mathrm{cfm})$ from $1 \mathrm{ft}$ to $25 \mathrm{ft}$ 448 to $460 \mathrm{~min}$ Mix column with air $(1700 \mathrm{cfm})$ from $25 \mathrm{ft}$ to surface, end of mix 


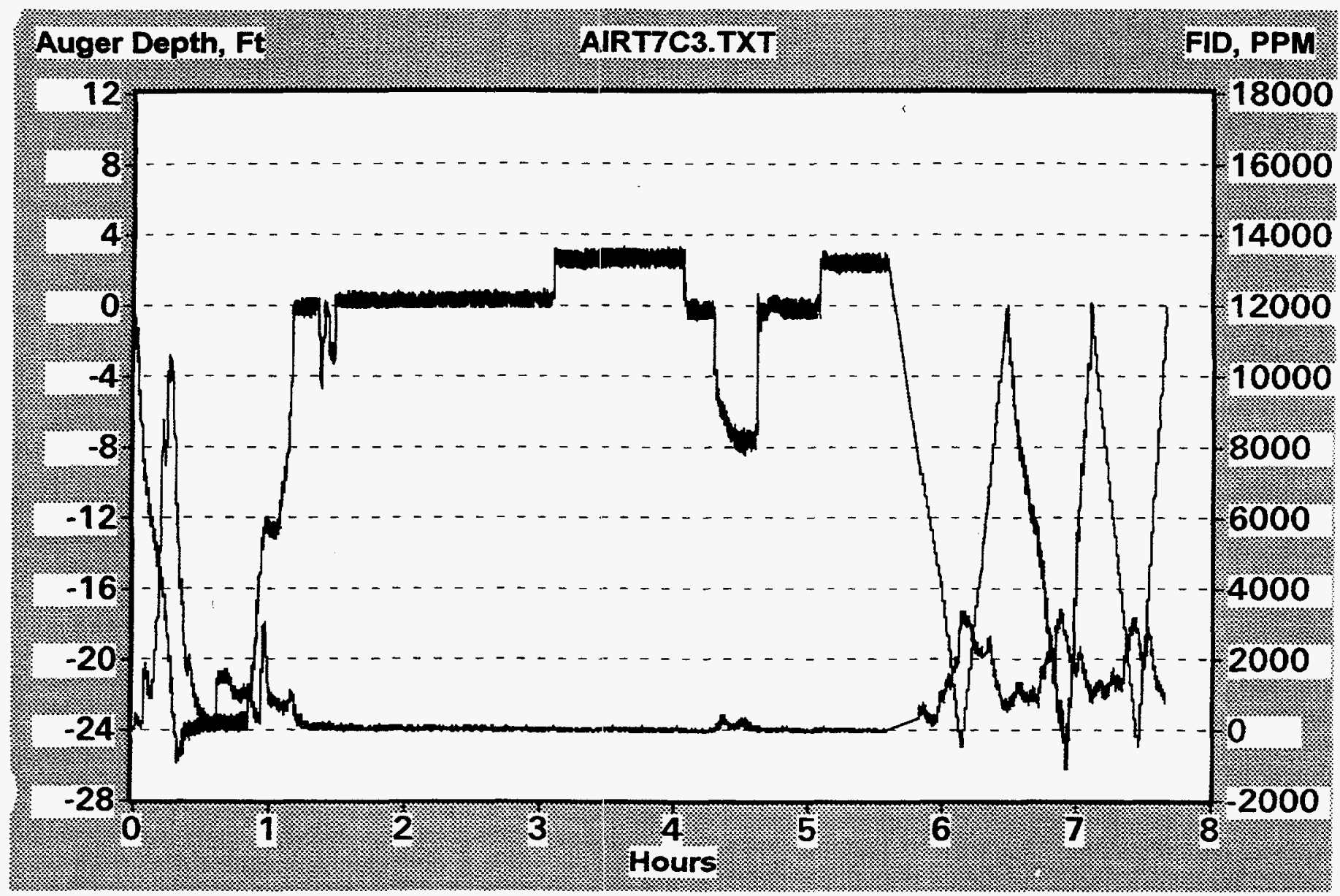




\section{APPENDIX D}

Treatability Studies Examining the Biodegradation of Trichloroethylene:

In Support of a Field Demonstration in Kansas City, MO 


\title{
Treatability Studies Examining the Biodegradation of Trichloroethylene: In Support of a Field Demonstration in Kansas City, Mo.
}

\author{
F. Gadelle, M. T. Gillespie and J. M. Strong-Gunderson* \\ PO Box 2008, Building 1505, MS 6038 \\ Oak Ridge National Laboratory \\ Oak Ridge, TN 327831-6038 USA \\ 423-576-0179, email PD9@ornl.gov.
}

The degradation of trichloroethylene (TCE) was carried out under both aqueous and slurry conditions. The bacteria used to degrade the TCE was Burkholderia cepacia G4 PR ${ }_{301}$ (G4) [M. Shields, University of West Florida].

The bacteria were grown in continuous culture in basalt salt media (BSM) (Hareland et al., 1975) with $20 \mathrm{mM}$ glucose as the sole carbon sourcc. Liquid cultures were routinely started from agar plates of a complex growth media R2A (Difco laboratories, Detroit, MI) or a specialized growth media of BSM $+20 \mathrm{mM}$ glucose, or $20 \mathrm{mM}$ sodium lactatc and $1.7 \%$ noble agar. The plates were scraped after 7 days and the bacteria rcsuspended in $10 \mathrm{~mL}$ of $\mathrm{BSM}+20 \mathrm{mM}$ glucose in a $15 \mathrm{~mL}$ sterile centrifuge tube. After a two-day incubation on a rotary shaker (250 $\mathrm{pm}$ ) at ambient lemperature, the optical density (OD) measured at a wavelength of $600 \mathrm{~nm}$ increased from 0 to $0.2-0.5$ (Gilford Response UV-Visible spectrophotometer, Oberlin, $\mathrm{OH}$ ). These cultures were then transferred into $90 \mathrm{~mL}$ of fresh media in a $250 \mathrm{~mL}$ Erlenmeyer llask and relumed to the shaker until OD $\geq 2.0$.

Expression of the enzyme responsible for TCE degradation, toluene orthomonooxygenase, was measured using the TFMP (trifluoromethylphenol or m-hydroxy benzotrifluoride) oxidation assay. The rate of production of TFHA (7,7,7-trifluoro-2hydroxy-6-oxo-2,4-heptadienoic acid), a yellow product, from TFMP oxidation correlates to the potential rate of TCE degradation by the enzyme (Shields et al., 1991; Shields and Reagin, 1992).

TCE biodegradation in aqueous and soil systems was monitored using.gas chromatography. Standards and samples, prepared in triplicate, were prepared in $15 \mathrm{~mL}$ glass vials. Each vial contained $5 \mathrm{~mL}$ of a phosphate buffered solution (PBS, $1.2 \mathrm{~g}$ 

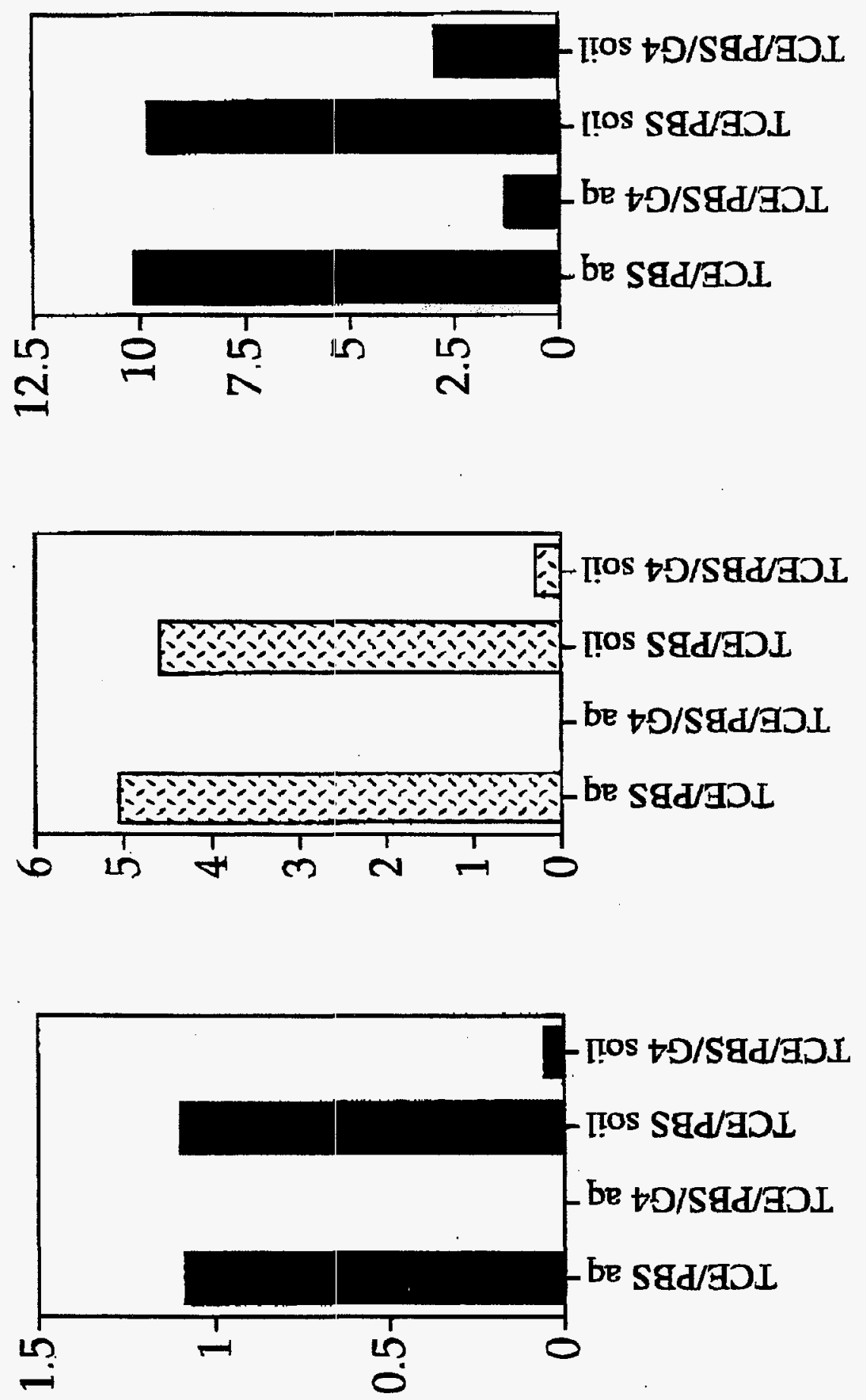

(udd) uọ̣exquasuoว GDL

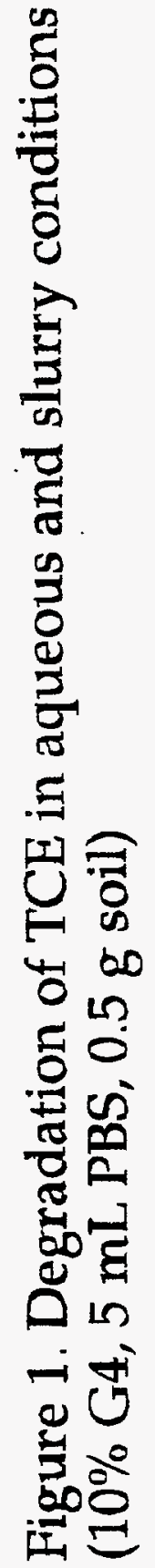




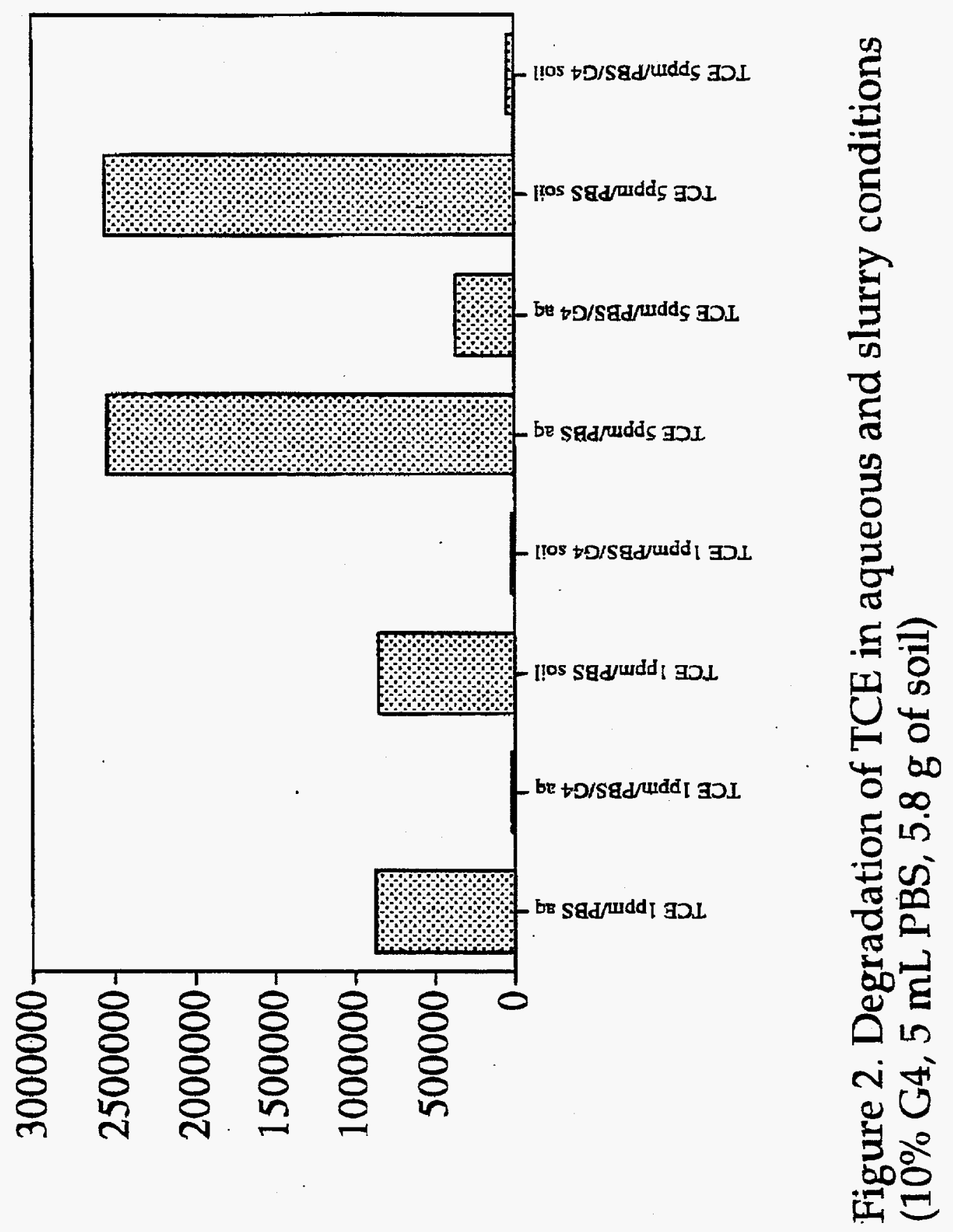

6aik >्रead 
$\mathrm{Na}_{2} \mathrm{HPO}_{4}, 2.2 \mathrm{~g} \mathrm{NaH}_{2} \mathrm{PO}_{4}, 8.7 \mathrm{~g} \mathrm{NaCl}$ in 1 Liter deionized waler), 10\% active $\mathrm{G} 4$ inoculum, and TCE (various concentrations). In some experiments, Kansas City soil was also added to the vials. The vials wcre then inverted and allowed to equilibratc on a rotary shaker. Headspace samples (volumc $30 \mu \mathrm{L}$ ) were analyzed using a Hewlert Packard gas chromatograph (HP5890 Series IJ. PJus, San Fernando, CA) equipped with a DB624 capillary column (Alitech, Deerficld, IL) and an electron capture detector. TCE was also extracted over a 24-hr period with $3 \mathrm{~mL}$ of hexane $+1 \mathrm{~mL}$ methanol. A $1 \mu \mathrm{L}$ extractant sample was injected into the gas chromatograph using an HP autosampler (HP 7673).

Figure 1 shows degradation to below the detection limits ( $<5 \mathrm{ppb}$ ) of TCE in aqueous solutions after a 48 -hour incubation pcriod. The samples contained $5 \mathrm{~mL}$ of the saline solution, a 10\% G4 inoculum and TCE at concentralions ranging from 1 to $10 \mathrm{ppm}$. These concentrations correspond to the range of concentrations observed in Test Cell 7 (The Kansas City field demonstration where the bioremediation is planned). For both 1 and 5 ppm concentrations, TCE was degraded to below $10 \mathrm{ppb}$ in 48 hours. This corresponds to a TCE biodegradation greater than $99.8 \%$. For the $10 \mathrm{ppm}$ concentration, $87.4 \%$ of the TCE was degraded during the same period of time (TCE final concentration $=1.28 \mathrm{ppm}$ ). Figure 1 also reports degradation of TCE under slurry conditions $(0.5 \mathrm{~g}$ of sterile soil was added to the sample vials). The percent of TCE degraded ranged from 70 to $95 \%$. It should be noted that these degradation cxperiments lasted 48 hours; however, enzymes will be active for several days. Indeed, Figure 2 shows that after ca. 100 hrs, 97 to $98 \%$ of TCE is degraded by G4. For this experiment, the soil-to-liquid volume ratio was 1 and the TCE concentrations were 1 and 5 ppm.

\section{$\underline{\text { References }}$}

Harcland, W., Crawtord, R. L., Chapman, P. J., and Dagley, S. (1975). "Metaholic Function and Properties of 4-Hydroxyphenylacetic Acjd 1-Hydroxylase from Pseudononas Acidoworans," J. Bacteriol., 121, 272.

Shields, M. S., Montgomery, S. O., Cuskey, S. M., Chapman, P. J., and Prirchard, P. H. (1991).

"Mutants of Pseudomonas cepacia 104 Defective in Catabolism of Aromatic Compounds and Trichloroethylene." Applied Environ. Microbiol. 57. 1935.

Shields. M. S., and Reagin, M. J. (1992). "Selection of a Pseudomonas cepacia Strain Constitutive for the Degradation of Trichloroethylene." Applied Environ. Micmbiol., 58, 3977. 


\section{APPENDIX E}

Kansas City Plant Deep Soil Mixing Demonstration Project

Post-treatment cis-1,2-DCE and TCE Content in Soil, $\mu \mathrm{g} / \mathrm{kg}$ and Groundwater, $\mu \mathrm{g} / \mathrm{L}$ 


\section{APPENDIX E}

\section{Kansas City Plant Deep Soil Mixing Demonstration Project}

Post-treatment $c i s-1,2-D C E$ and TCE Content in Soil, $\mu \mathrm{g} / \mathrm{kg}$ and Groundwater, $\mu \mathrm{g} / \mathrm{L}$

\section{Post-treatment samples from T3 Cell}

\section{Post-T3B1}

\begin{tabular}{|c|c|c|c|c|c|c|c|}
\hline Sample & Depth & Weight, g & Dilution & $\begin{array}{l}\text { cis-DCE, } \\
\text { gross }\end{array}$ & $\begin{array}{l}\text { cis-DCE, } \\
\mu \mathrm{g} / \mathrm{kg}\end{array}$ & $\begin{array}{l}\text { TCE, } \\
\text { gross }\end{array}$ & $\begin{array}{c}\text { TCE, } \\
\mu \mathbf{g} / \mathbf{k g}\end{array}$ \\
\hline 5 & 6.5 & 4.45 & $10 x$ & ND & ND & 8549 & 9606 \\
\hline 6 & 9.0 & 4.34 & $100 x$ & ND & ND & 22,754 & 26,214 \\
\hline 7 & 12.0 & 4.33 & $10 x$ & ND & ND & 11,258 & 13,000 \\
\hline 8 & 14.0 & 2.76 & $100 x$ & $\mathrm{ND}$ & ND & 104,231 & 188,824 \\
\hline 9 & 17.0 & 3.70 & $100 x$ & ND & ND & 141,105 & 190,682 \\
\hline 10 & 22.0 & 3.23 & $100 x$ & ND & ND & 62,417 & 96,621 \\
\hline 11 & 27.0 & 3.88 & $1 \mathrm{x}$ & ND & ND & 1570 & 2023 \\
\hline $5 S$ & $T 3 B 1.01 \mathrm{~W}$ & $N A$ & $100 x$ & $N D$ & $N D$ & $26,474 \mathrm{~g} / L$ & $N /$ \\
\hline
\end{tabular}

Post-T3B2

$\begin{array}{llllllll}\text { Sample } & \text { Depth } & \text { Weight, } & \text { Dilution } & \begin{array}{l}\text { cis-DCE, } \\ \text { gross }\end{array} & \begin{array}{l}\text { cis-DCE, } \\ \mu \mathrm{g} / \mathrm{kg}\end{array} & \begin{array}{l}\text { TCE, } \\ \text { gross }\end{array} & \begin{array}{l}\text { TCE, } \\ \mu \mathrm{g} / \mathrm{kg}\end{array} \\ 12 & 5.0 & 5.13 & 100 \mathrm{x} & \text { ND } & \text { ND } & 12,800 & 12,476 \\ 13 & 9.0 & 2.74 & 100 \mathrm{x} & \text { ND } & \text { ND } & 9740 & 17,774 \\ 14 & 12.0 & 4.41 & 100 \mathrm{x} & \text { ND } & \text { ND } & 64,500 & 73,129 \\ 15 & 14.0 & 4.12 & 100 \mathrm{x} & \text { ND } & \text { ND } & 14,040 & 17,039 \\ 16 & 16.0 & 3.47 & 100 \mathrm{x} & \text { ND } & \text { ND } & 121,500 & 175,072 \\ 17 & 22.0 & 4.16 & 100 \mathrm{x} & \text { ND } & \text { ND } & 123,300 & 148,197 \\ 18 & 26.0 & 3.15 & 10 \mathrm{x} & \text { ND } & \text { ND } & 2650 & 4206\end{array}$

Post-T3B3

\begin{tabular}{|c|c|c|c|c|c|c|c|}
\hline Sample & Depth & Weight, g & Dilution & $\begin{array}{l}\text { cis-DCE, } \\
\text { gross }\end{array}$ & $\begin{array}{l}\text { cis-DCE, } \\
\mu \mathrm{g} / \mathrm{kg}\end{array}$ & $\begin{array}{l}\text { TCE, } \\
\text { gross }\end{array}$ & $\begin{array}{l}\text { TCE, } \\
\mu \mathrm{g} / \mathrm{kg}\end{array}$ \\
\hline 19 & 5.0 & 4.20 & $10 x$ & $\mathrm{ND}$ & ND & 4400 & 5238 \\
\hline 20 & 9.0 & 3.71 & $10 x$ & ND & ND & 7116 & 9590 \\
\hline 21 & 12.0 & 3.17 & $10 x$ & ND & ND & 13,660 & 21,546 \\
\hline 22 & 14.0 & 2.81 & $100 x$ & ND & ND & 37,793 & 67,247 \\
\hline 23 & 17.0 & 4.50 & $100 x$ & $\mathrm{ND}$ & ND & 110,052 & 122,280 \\
\hline 24 & 22.0 & 4.19 & $100 x$ & ND & ND & 140,741 & 167,949 \\
\hline 25 & 27.0 & 4.66 & $10 x$ & ND & ND & 9311 & 9990 \\
\hline \multicolumn{2}{|c|}{$53 \mathrm{~T} 3 \mathrm{~B} 3-0 \mathrm{TW}$} & $N A$ & $100 x$ & $N D$ & $N D$ & $48165 \mathrm{~g} / \mathrm{L}$ & $N A$ \\
\hline
\end{tabular}




\section{E-2}

\section{Post-T3B4}

\begin{tabular}{llllllll}
\hline Sample & Depth & Weight, & Dilution & $\begin{array}{l}\text { cis-DCE, } \\
\text { gross }\end{array}$ & $\begin{array}{l}\text { cis-DCE, } \\
\mu \mathrm{g} / \mathbf{k g}\end{array}$ & $\begin{array}{l}\text { TCE, } \\
\text { gross }\end{array}$ & $\begin{array}{l}\text { TCE, } \\
\mu \mathrm{g} / \mathbf{k g}\end{array}$ \\
26 & 5.0 & 3.34 & $10 \mathrm{x}$ & ND & ND & 4188 & 6269 \\
27 & 9.0 & 4.66 & $10 \mathrm{x}$ & ND & ND & 5903 & 6334 \\
28 & 15.0 & 3.47 & $100 \mathrm{x}$ & ND & ND & 44,303 & 63,837 \\
29 & 17.0 & 3.94 & $100 \mathrm{x}$ & ND & ND & 123,837 & 157,154 \\
30 & 23.0 & 3.75 & $100 \mathrm{x}$ & ND & ND & 120,190 & 160,253 \\
31 & 27.0 & 3.98 & $100 \mathrm{x}$ & ND & ND & 43,702 & 54,902
\end{tabular}

\section{Post-T3B5}

\begin{tabular}{|c|c|c|c|c|c|c|c|}
\hline Sample & Depth & Weight, g & Dilution & $\begin{array}{l}\text { cis-DCE, } \\
\text { gross }\end{array}$ & $\begin{array}{l}\text { cis-DCE, } \\
\mu \mathrm{g} / \mathrm{kg}\end{array}$ & $\begin{array}{l}\text { TCE, } \\
\text { gross }\end{array}$ & $\begin{array}{l}\text { TCE, } \\
\mu \mathrm{g} / \mathrm{kg}\end{array}$ \\
\hline 32 & 5.0 & 2.95 & $10 x$ & ND & $\mathrm{ND}$ & 4420 & 7492 \\
\hline 33 & 9.0 & 3.32 & $10 x$ & ND & $\mathrm{ND}$ & 10,437 & 15,718 \\
\hline 34 & 17.0 & 4.85 & $1000 \mathrm{x}$ & ND & $\mathrm{ND}$ & 238,152 & 245,518 \\
\hline 35 & 22.0 & 4.13 & $1000 x$ & ND & ND & 168,834 & 204,400 \\
\hline 36 & 27.0 & 3.83 & $100 x$ & ND & ND & 104,737 & 136,732 \\
\hline \multicolumn{2}{|c|}{$54 T 3 B 5-01 W$} & $N A$ & $1 x$ & $N D$ & $N D$ & $N D$ & $N A$ \\
\hline
\end{tabular}

\section{Post-T3B6}

\begin{tabular}{llllllll}
\hline Sample & Depth & Weight, & Dilution & $\begin{array}{l}\text { cis-DCE, } \\
\text { gross }\end{array}$ & $\begin{array}{l}\text { cis-DCE, } \\
\mu \text { g/kg }\end{array}$ & $\begin{array}{l}\text { TCE, } \\
\text { gross }\end{array}$ & $\begin{array}{l}\text { TCE, } \\
\mu \text { g/kg }\end{array}$ \\
38 & 5.0 & 3.93 & $10 \mathrm{x}$ & ND & ND & 777 & 989 \\
39 & 9.0 & 3.22 & $1 \times$ & ND & ND & 243 & 377 \\
40 & 12.0 & 1.84 & $10 \times$ & ND & ND & 1525 & 4144 \\
41 & 14.0 & 4.85 & $1000 \times$ & ND & ND & 526,941 & 543,238 \\
42 & 17.0 & 3.66 & $1000 x$ & ND & ND & 659,404 & 900,825 \\
43 & 22.0 & 3.07 & $100 x$ & ND & ND & 16,433 & 26,764 \\
44 & 27.0 & 4.67 & $100 x$ & ND & ND & 92,503 & 99,040
\end{tabular}




\section{E-3}

Post-T3B7

\begin{tabular}{llllllll}
\hline Sample & Depth & Weight, & Dilution & $\begin{array}{l}\text { cis-DCE, } \\
\text { gross }\end{array}$ & $\begin{array}{l}\text { cis-DCE, } \\
\mu \mathrm{g} / \mathbf{k g}\end{array}$ & $\begin{array}{l}\text { TCE, } \\
\text { gross }\end{array}$ & $\begin{array}{l}\text { TCE, } \\
\mu \mathrm{g} / \mathbf{k g}\end{array}$ \\
45 & 5.0 & 2.54 & $10 \mathrm{x}$ & $\mathrm{ND}$ & $\mathrm{ND}$ & 7458 & 14,681 \\
46 & 9.0 & 5.70 & $10 \mathrm{x}$ & $\mathrm{ND}$ & $\mathrm{ND}$ & 7006 & 6146 \\
47 & 11.0 & 5.34 & $100 \mathrm{x}$ & $\mathrm{ND}$ & $\mathrm{ND}$ & 80,477 & 75,353 \\
48 & 14.0 & 4.49 & $100 \mathrm{x}$ & ND & ND & 91,851 & 102,284 \\
49 & 17.0 & 4.03 & $100 \mathrm{x}$ & ND & ND & 129,718 & 160,940 \\
50 & 22.0 & 2.48 & $100 \mathrm{x}$ & D & ND & 148,499 & 299,393 \\
51 & 27.0 & 3.84 & $10 \mathrm{x}$ & ND & ND & 10,736 & 13,979
\end{tabular}

Post-T3B5A

$\begin{array}{llllllll}\text { Sample } & \text { Depth } & \text { Weight, g Dilution } & \begin{array}{l}\text { cis-DCE, } \\ \text { gross }\end{array} & \begin{array}{l}\text { cis-DCE, } \\ \mu \mathrm{g} / \mathbf{k g}\end{array} & \begin{array}{l}\text { TCE, } \\ \text { gross }\end{array} & \begin{array}{l}\text { TCE, } \\ \mu \mathbf{g} / \mathbf{k g}\end{array} \\ 152 & 5.0 & 3.51 & 10 \mathrm{x} & \text { ND } & \text { ND } & 6089 & 8674 \\ 153 & 9.0 & 3.84 & 10 \mathrm{x} & \text { ND } & \text { ND } & 8941 & 11,642 \\ 154 & 12.0 & 4.30 & 100 \mathrm{x} & \text { ND } & \text { ND } & 49,002 & 56,979 \\ 155 & 14.0 & 3.40 & 1000 \mathrm{x} & \text { ND } & \text { ND } & 145,062 & 213,326 \\ 156 & 17.0 & 3.54 & 1000 \mathrm{x} & \text { ND } & \text { ND } & 197,614 & 279,116 \\ 157 & 22.0 & 3.10 & 100 \mathrm{x} & \text { ND } & \text { ND } & 99,674 & 160,765 \\ 158 & 27.0 & 3.38 & 100 \mathrm{x} & \text { ND } & \text { ND } & 80,013 & 118,362\end{array}$

\section{Post-T3B3A}

$\begin{array}{llllllll}\text { Sample } & \text { Depth } & \text { Weight, g } & \text { Dilution } & \begin{array}{l}\text { cis-DCE, } \\ \text { gross }\end{array} & \begin{array}{l}\text { cis-DCE, } \\ \mu \mathrm{g} / \mathbf{k g}\end{array} & \begin{array}{l}\text { TCE, } \\ \text { gross }\end{array} & \begin{array}{l}\text { TCE, } \\ \mu \mathrm{g} / \mathbf{k g}\end{array} \\ 159 & 5.0 & 3.65 & 10 \mathrm{x} & \text { ND } & \text { ND } & 5616 & 7693 \\ 160 & 9.0 & 3.77 & 10 \mathrm{x} & \text { ND } & \text { ND } & 6715 & 8906 \\ 161 & 12.0 & 4.25 & 100 \mathrm{x} & \text { ND } & \text { ND } & 19,430 & 22,859 \\ 162 & 14.0 & 3.03 & 100 x & \text { ND } & \text { ND } & 81,933 & 135,203 \\ 163 & 17.0 & 3.44 & 100 x & \text { ND } & \text { ND } & 89,763 & 130,469 \\ 164 & 22.0 & 4.21 & 100 x & \text { ND } & \text { ND } & 96,293 & 114,362 \\ 165 & 27.0 & 2.84 & 100 x & \text { ND } & \text { ND } & 13,250 & 23,327\end{array}$


Post-T3B1A

\begin{tabular}{llllllll}
\hline Sample & Depth & Weight, & Dilution & $\begin{array}{l}\text { cis-DCE, } \\
\text { gross }\end{array}$ & $\begin{array}{l}\text { cis-DCE, } \\
\mu \mathrm{g} / \mathbf{k g}\end{array}$ & $\begin{array}{l}\text { TCE, } \\
\text { gross }\end{array}$ & $\begin{array}{l}\text { TCE, } \\
\mu \mathbf{g} / \mathbf{k g}\end{array}$ \\
166 & 5.0 & 3.29 & $10 \mathrm{x}$ & ND & ND & 4186 & 6362 \\
167 & 9.0 & 3.61 & $10 \mathrm{x}$ & ND & ND & 112,64 & 15,601 \\
168 & 12.0 & 3.69 & $100 \mathrm{x}$ & ND & ND & 9522 & 12,902 \\
169 & 14.0 & 4.06 & $100 \mathrm{x}$ & ND & ND & 20,455 & 25,191 \\
170 & 17.0 & 4.15 & $100 \mathrm{x}$ & ND & ND & 101,568 & 122,371 \\
171 & 22.0 & 3.58 & $100 \mathrm{x}$ & ND & ND & 74,234 & 103,679 \\
172 & 27.0 & 4.19 & $10 \mathrm{x}$ & ND & ND & 4944 & 5900
\end{tabular}

Post-T3B6A

\begin{tabular}{llllllll}
\hline Sample & Depth & Weight, & Dilution & $\begin{array}{l}\text { cis-DCE, } \\
\text { gross }\end{array}$ & $\begin{array}{l}\text { cis-DCE, } \\
\mu \text { g/kg }\end{array}$ & $\begin{array}{l}\text { TCE, } \\
\text { gross }\end{array}$ & $\begin{array}{l}\text { TCE, } \\
\mu \mathrm{g} / \mathbf{k g}\end{array}$ \\
174 & 5.0 & 2.83 & $10 \mathrm{x}$ & ND & ND & 1621 & 2864 \\
175 & 9.0 & 3.33 & $10 \mathrm{x}$ & ND & ND & 7530 & 11,306 \\
176 & 12.0 & 3.02 & $10 \mathrm{x}$ & ND & ND & 8581 & 14,207 \\
177 & 14.0 & 3.05 & $100 \mathrm{x}$ & ND & ND & 15,468 & 25,357 \\
178 & 17.0 & 2.96 & $1000 \mathrm{x}$ & ND & ND & 206,331 & 348,532 \\
179 & 22.0 & 2.92 & $100 \mathrm{x}$ & ND & ND & 14,457 & 24,755 \\
180 & 27.0 & 3.06 & $100 \mathrm{x}$ & ND & ND & 21,194 & 34,631
\end{tabular}

Post-T3B7A

\begin{tabular}{llllllll}
\hline Sample & Depth & Weight, D Dilution & $\begin{array}{l}\text { cis-DCE, } \\
\text { gross }\end{array}$ & $\begin{array}{l}\text { cis-DCE, } \\
\mu \mathrm{g} / \mathrm{kg}\end{array}$ & $\begin{array}{l}\text { TCE, } \\
\text { gross }\end{array}$ & $\begin{array}{l}\text { TCE, } \\
\mu \mathrm{g} / \mathrm{kg}\end{array}$ \\
181 & 5.0 & 3.68 & $10 \mathrm{x}$ & ND & ND & 1023 & 1390 \\
182 & 9.0 & 3.71 & $1 \mathrm{x}$ & ND & ND & $\mathbf{8 7 6}$ & 1181 \\
183 & 12.0 & 3.14 & $100 \mathrm{x}$ & ND & ND & 9485 & 15,104 \\
184 & 14.0 & 3.31 & $100 \mathrm{x}$ & ND & ND & 96,891 & 146,361 \\
185 & 17.0 & 3.31 & $100 \mathrm{x}$ & ND & ND & 90,274 & 136,366 \\
186 & 22.0 & 2.64 & $1000 \mathrm{x}$ & ND & ND & 203,844 & 386,068 \\
187 & 27.0 & 2.73 & $100 \mathrm{x}$ & ND & ND & 15,842 & 29,015 \\
\hline
\end{tabular}

D: soil sample duplicate

W: groundwater sample (denoted by italics and shading)

NA: not applicable

ND: not detected 
E-5

Post-treatment samples from T4 Cell

Post-T4B1

$\begin{array}{llllllll}\text { Sample } & \text { Depth } & \text { Weight, } & \text { Dilution } & \begin{array}{l}\text { cis-DCE, } \\ \text { gross }\end{array} & \begin{array}{l}\text { cis-DCE, } \\ \mu \mathrm{g} / \mathrm{kg}\end{array} & \begin{array}{l}\text { TCE, } \\ \text { gross }\end{array} & \begin{array}{l}\text { TCE, } \\ \mu \mathrm{g} / \mathbf{k g}\end{array} \\ 96 & 1.0 & 3.70 & 10 \mathrm{x} & \mathrm{ND} & \mathrm{ND} & \mathbf{1 7 1 8} & 2322 \\ 97 & 3.0 & 3.65 & 10 \mathrm{x} & \mathrm{ND} & \mathrm{ND} & 6551 & 8974 \\ 98 & 7.0 & 3.77 & 10 \mathrm{x} & \mathrm{ND} & \mathrm{ND} & 5863 & 7776 \\ 99 & 12.0 & 4.69 & 1000 \mathrm{x} & \text { ND } & \text { ND } & 897,368 & 956,682 \\ 100 & 17.0 & 3.69 & 1000 \mathrm{x} & \text { ND } & \text { ND } & 206,312 & 279,556 \\ 101 & 22.0 & 3.70 & 100 \mathrm{x} & \text { ND } & \text { ND } & 81,172 & 109,692 \\ 102 & 27.0 & 3.56 & 1000 \mathrm{x} & \text { ND } & \text { ND } & 308,083 & 432,701 \\ 103 & 32.0 & 4.81 & 100 \mathrm{x} & \text { ND } & \text { ND } & 78,650 & 81,757 \\ 104 & 37.0 & 2.93 & 10 \mathrm{x} & \text { ND } & \text { ND } & 9819 & 16,756\end{array}$

Post-T4B2

\begin{tabular}{llllllll}
\hline Sample & Depth & Weight, g & Dilution & $\begin{array}{l}\text { cis-DCE, } \\
\text { gross }\end{array}$ & $\begin{array}{l}\text { cis-DCE, } \\
\mu \mathbf{g} / \mathbf{k g}\end{array}$ & $\begin{array}{l}\text { TCE, } \\
\text { gross }\end{array}$ & $\begin{array}{l}\text { TCE, } \\
\mu \text { g/kg }\end{array}$ \\
105 & 1.0 & 2.04 & $10 \mathrm{x}$ & ND & ND & 1617 & 3963 \\
106 & 3.0 & 2.85 & $10 \mathrm{x}$ & ND & ND & 4068 & 7137 \\
107 & 7.0 & 3.88 & $10 \mathrm{x}$ & ND & ND & 4605 & 5934 \\
108 & 12.0 & 3.34 & $100 \mathrm{x}$ & ND & ND & 43,792 & 65,557 \\
109 & 17.0 & 3.15 & $100 \mathrm{x}$ & ND & ND & 44,525 & 70,675 \\
110 & 22.0 & 2.70 & $10 \mathrm{x}$ & ND & ND & 13,127 & 24,309 \\
111 & 27.0 & 3.44 & $100 \mathrm{x}$ & ND & ND & 41,469 & 60,275 \\
112 & 32.0 & 4.90 & $100 \mathrm{x}$ & ND & ND & 101,111 & 103,174 \\
113 & 37.0 & 2.89 & $100 \mathrm{x}$ & ND & ND & 24,646 & 42,640
\end{tabular}

\section{Post-T4B3}

\begin{tabular}{|c|c|c|c|c|c|c|c|}
\hline Sample & Depth & Weight, g & Dilution & $\begin{array}{l}\text { cis-DCE, } \\
\text { gross }\end{array}$ & $\begin{array}{l}\text { cis-DCE, } \\
\mu \mathrm{g} / \mathrm{kg}\end{array}$ & $\begin{array}{l}\text { TCE, } \\
\text { gross }\end{array}$ & $\begin{array}{l}\text { TCE, } \\
\mu \mathrm{g} / \mathrm{kg}\end{array}$ \\
\hline 116 & 5.0 & 2.83 & $10 x$ & ND & ND & 6365 & 11,246 \\
\hline $117^{-}$ & 7.0 & 2.68 & $10 \mathrm{x}$ & ND & ND & 6922 & 12,914 \\
\hline 118 & 12.0 & 2.91 & $100 x$ & ND & ND & 40,490 & 69,570 \\
\hline 119 & 17.0 & 3.17 & $100 x$ & ND & ND & 46,023 & 72,591 \\
\hline 120 & 22.0 & 3.35 & $100 x$ & ND & ND & 51,678 & 77,131 \\
\hline 121 & 27.0 & 5.01 & $100 x$ & $\mathrm{ND}$ & ND & 84,448 & 84,279 \\
\hline 122 & 32.0 & 4.67 & $100 x$ & ND & ND & 91,959 & 98,457 \\
\hline 123 & 37.0 & 3.95 & $100 x$ & $\mathrm{ND}$ & ND & 33,250 & 42,089 \\
\hline \multicolumn{2}{|c|}{$218 \mathrm{~T} 4 \mathrm{~B} 3-02 \mathrm{~W}$} & - NA & $10 x$ & ND & ND & $4196 \mu \mathrm{g} / \mathrm{L}$ & NA \\
\hline
\end{tabular}


Post-T4B4

\begin{tabular}{llllllll}
\hline Sample & Depth & Weight, g & Dilution & $\begin{array}{l}\text { cis-DCE, } \\
\text { gross }\end{array}$ & $\begin{array}{l}\text { cis-DCE, } \\
\mu \mathbf{g} / \mathbf{k g}\end{array}$ & $\begin{array}{l}\text { TCE, } \\
\text { gross }\end{array}$ & $\begin{array}{l}\text { TCE, } \\
\mu \mathrm{g} / \mathbf{k g}\end{array}$ \\
& & & & & & & \\
124 & 1.0 & 3.77 & $10 \mathrm{x}$ & ND & ND & 3392 & 4499 \\
125 & 3.0 & 3.87 & $10 \mathrm{x}$ & ND & ND & 3947 & 5099 \\
126 & 7.0 & 4.10 & $10 \mathrm{x}$ & ND & ND & 8662 & 10,563 \\
127 & 12.0 & 4.70 & $100 \mathrm{x}$ & ND & ND & 56,125 & 59,707 \\
128 & 17.0 & 3.38 & $100 \mathrm{x}$ & ND & ND & 116,193 & 171,883 \\
129 & 22.0 & 3.82 & $100 \mathrm{x}$ & ND & ND & 53,660 & 70,236 \\
130 & 27.0 & 4.24 & $100 \mathrm{x}$ & ND & ND & 127,128 & 149,915 \\
131 & 32.0 & 4.71 & $100 \mathrm{x}$ & ND & ND & 56,436 & 59,911 \\
132 & 37.0 & 4.72 & $100 \mathrm{x}$ & ND & ND & 25,612 & 27,131
\end{tabular}

Post-T4B5

\begin{tabular}{|c|c|c|c|c|c|c|c|}
\hline Sample & Depth & Weight, g & Dilution & $\begin{array}{l}\text { cis-DCE, } \\
\text { gross }\end{array}$ & $\begin{array}{l}\text { cis-DCE, } \\
\mu \mathrm{g} / \mathrm{kg}\end{array}$ & $\begin{array}{l}\text { TCE, } \\
\text { gross }\end{array}$ & $\begin{array}{l}\text { TCE, } \\
\mu \mathrm{g} / \mathrm{kg}\end{array}$ \\
\hline 133 & 1.0 & 3.70 & $1 \mathrm{x}$ & ND & $\mathrm{ND}$ & 1041 & 1407 \\
\hline 134 & 3.0 & 3.82 & $1 x$ & ND & ND & 895 & 1171 \\
\hline 135 & 7.0 & 4.70 & $1 x$ & ND & ND & 772 & 821 \\
\hline 136 & 12.0 & 3.76 & $10 x$ & $\mathrm{ND}$ & $\mathrm{ND}$ & 2181 & 2900 \\
\hline 137 & 17.0 & 4.40 & $10 \mathrm{x}$ & ND & $\mathrm{ND}$ & 6149 & 6988 \\
\hline 138 & 22.0 & 2.96 & $10 x$ & ND & $\mathrm{ND}$ & 5172 & 8736 \\
\hline 139 & 27.0 & 4.19 & $10 x$ & ND & $\mathrm{ND}$ & 8727 & 10,414 \\
\hline 140 & 32.0 & 3.27 & $100 x$ & ND & $\mathrm{ND}$ & 44,222 & 67,618 \\
\hline 141 & 37.0 & 4.50 & $10 x$ & ND & ND & 5221 & 5801 \\
\hline
\end{tabular}

Post-T4B6

\begin{tabular}{|c|c|c|c|c|c|c|c|}
\hline Sample & Depth & Weight, g & Dilution & $\begin{array}{l}\text { cis-DCE, } \\
\text { gross }\end{array}$ & $\begin{array}{l}\text { cis-DCE, } \\
\mu \mathrm{g} / \mathrm{kg}\end{array}$ & $\begin{array}{l}\text { TCE, } \\
\text { gross }\end{array}$ & $\begin{array}{l}\text { TCE, } \\
\mu \mathrm{g} / \mathrm{kg}\end{array}$ \\
\hline 142 & 1.0 & 4.57 & $10 x$ & ND & ND & 6321 & 6916 \\
\hline 143 & 3.0 & 3.86 & $10 x$ & ND & ND & 2746 & 3557 \\
\hline 144 & 7.0 & 4.26 & $10 \mathrm{x}$ & ND & ND & 10,132 & 11,892 \\
\hline 145 & 12.0 & 4.35 & $100 x$ & $\mathrm{ND}$ & $\mathrm{ND}$ & 37,453 & 43,049 \\
\hline $146-$ & 17.0 & 4.98 & $100 x$ & ND & ND & 74,652 & 74,952 \\
\hline 147 & 22.0 & 6.06 & $100 x$ & ND & ND & 97,691 & 80,603 \\
\hline 148 & 27.0 & 4.81 & $100 x$ & ND & ND & 110,625 & 114,995 \\
\hline 149 & 32.0 & 4.76 & $100 x$ & ND & ND & 59,319 & 62,310 \\
\hline 150 & 37.0 & 5.03 & $100 x$ & ND & $\mathrm{ND}$ & 30,515 & 30,333 \\
\hline
\end{tabular}

D: soil sample duplicate

W: groundwater sample (denoted by italics and shading)

NA: not applicable

ND: not detected 
Post-treatment samples from T5 Cell

\section{Post-T5B1}

$\begin{array}{llllllll}\text { Sample } & \text { Depth } & \text { Weight, g } & \text { Dilution } & \begin{array}{l}\text { cis-DCE, } \\ \text { gross }\end{array} & \begin{array}{l}\text { cis-DCE, } \\ \mu \mathrm{g} / \mathbf{k g}\end{array} & \begin{array}{l}\text { TCE, } \\ \text { gross }\end{array} & \begin{array}{l}\text { TCE, } \\ \mu \mathbf{g} / \mathbf{k g}\end{array} \\ 65 & 3.0 & 2.77 & 10 \mathrm{x} & \text { ND } & \text { ND } & 1091 & 1969 \\ 66 & 7.0 & 4.52 & 10 \mathrm{x} & \text { ND } & \text { ND } & 3674 & 4064 \\ 67 & 12.0 & 2.33 & 10 \mathrm{x} & \text { ND } & \text { ND } & 11,963 & 25,672 \\ 68 & 17.0 & 3.72 & 100 \mathrm{x} & \text { ND } & \text { ND } & 45,262 & 60,836 \\ 69 & 25.0 & 2.96 & 10 \mathrm{x} & \text { ND } & \text { ND } & 10,044 & 16,966 \\ 70 & 27.0 & 3.09 & 100 \mathrm{x} & \text { ND } & \text { ND } & 46,565 & 75,348\end{array}$

\section{Post-T5B2}

$\begin{array}{llllllll}\text { Sample } & \text { Depth } & \text { Weight, g } & \text { Dilution } & \begin{array}{l}\text { cis-DCE, } \\ \text { gross }\end{array} & \begin{array}{l}\text { cis-DCE, } \\ \mu \mathrm{g} / \mathbf{k g}\end{array} & \begin{array}{l}\text { TCE, } \\ \text { gross }\end{array} & \begin{array}{l}\text { TCE, } \\ \mu \mathrm{g} / \mathbf{k g}\end{array} \\ 72 & 7.0 & 2.98 & 100 \mathrm{x} & \mathrm{ND} & \mathrm{ND} & 17,407 & 29,206 \\ 73 & 12.0 & 3.42 & 10 \mathrm{x} & \text { ND } & \text { ND } & 1964 & 2871 \\ 74 & 17.0 & 3.08 & 10 \mathrm{x} & \mathrm{ND} & \mathrm{ND} & 3918 & 6360 \\ 75 & 22.0 & 4.36 & 10 \mathrm{x} & \text { ND } & \text { ND } & 4129 & 4735 \\ 76 & 27.0 & 4.93 & 100 \mathrm{x} & \text { ND } & \text { ND } & 24,577 & 24,926\end{array}$

Post-T5B3

\begin{tabular}{llllllll}
\hline Sample & Depth & Weight, g & Dilution & $\begin{array}{l}\text { cis-DCE, } \\
\text { gross }\end{array}$ & $\begin{array}{l}\text { cis-DCE, } \\
\mu \text { g/kg }\end{array}$ & $\begin{array}{l}\text { TCE, } \\
\text { gross }\end{array}$ & $\begin{array}{l}\text { TCE, } \\
\mu \text { g/kg }\end{array}$ \\
& & & & & & & \\
77 & 3.0 & 3.30 & $10 \mathrm{x}$ & ND & ND & 455 & 689 \\
78 & 7.0 & 4.80 & $10 \mathrm{x}$ & ND & ND & 2439 & 2541 \\
79 & 12.0 & 4.33 & $100 \mathrm{x}$ & ND & ND & 14,497 & 16,740 \\
80 & 17.0 & 2.03 & $10 \mathrm{x}$ & ND & ND & 5895 & 14,520 \\
81 & 22.0 & 1.90 & $10 \mathrm{x}$ & ND & ND & 3571 & 9397 \\
82 & -27.0 & 3.31 & $10 \mathrm{x}$ & ND & ND & 4483 & 6772 \\
& & & & & & & \\
114 & T5B3-01W & NA & $10 \mathrm{x}$ & ND & ND & $4172 \mu \mathrm{g} / \mathrm{L}$ & NA \\
219 & T5B3-02W & NA & $10 \mathrm{x}$ & ND & ND & $2145 \mu \mathrm{g} / \mathrm{L}$ & NA
\end{tabular}


Post-T5B4

\begin{tabular}{llllllll}
\hline Sample & Depth & Weight, & Dilution & $\begin{array}{l}\text { cis-DCE, } \\
\text { gross }\end{array}$ & $\begin{array}{l}\text { cis-DCE, } \\
\mu \mathrm{g} / \mathrm{kg}\end{array}$ & $\begin{array}{l}\text { TCE, } \\
\text { gross }\end{array}$ & $\begin{array}{l}\text { TCE, } \\
\mu \mathrm{g} / \mathrm{kg}\end{array}$ \\
84 & 3.0 & 4.20 & $10 \mathrm{x}$ & $\mathrm{ND}$ & $\mathrm{ND}$ & 1025 & 1220 \\
85 & 7.0 & 3.60 & $10 \mathrm{x}$ & ND & ND & 2345 & 3257 \\
86 & 12.0 & 2.67 & $100 \mathrm{x}$ & ND & ND & 44,605 & 83,530 \\
87 & 17.0 & 2.55 & $100 \mathrm{x}$ & ND & ND & 34,367 & 67,386 \\
88 & 22.0 & 3.32 & $10 \mathrm{x}$ & ND & ND & 5316 & 8006 \\
89 & 27.0 & 3.41 & $10 \mathrm{x}$ & ND & ND & 248 & 364
\end{tabular}

Post-T5B5

\begin{tabular}{llllllll}
\hline Sample & Depth & Weight, g Dilution & $\begin{array}{l}\text { cis-DCE, } \\
\text { gross }\end{array}$ & $\begin{array}{l}\text { cis-DCE, } \\
\mu \text { g/kg }\end{array}$ & $\begin{array}{l}\text { TCE, } \\
\text { gross }\end{array}$ & $\begin{array}{l}\text { TCE, } \\
\mu \mathbf{g} / \mathbf{k g}\end{array}$ \\
90 & 3.0 & 4.08 & 1x & ND & ND & 742 & 909 \\
91 & 7.0 & 2.54 & $1 \mathrm{x}$ & ND & ND & 449 & 884 \\
92 & 12.0 & 1.84 & $1 \mathrm{x}$ & ND & ND & 810 & 2201 \\
93 & 17.0 & 2.83 & $1 \mathrm{x}$ & ND & ND & 621 & 1097 \\
94 & 22.0 & 3.38 & $1 \mathrm{x}$ & ND & ND & 146 & 216 \\
95 & 27.0 & 4.39 & $1 \mathrm{x}$ & ND & ND & 559 & 637
\end{tabular}

Post-T5B6

\begin{tabular}{llllllll}
\hline Sample & Depth & Weight, & Dilution & $\begin{array}{l}\text { cis-DCE, } \\
\text { gross }\end{array}$ & $\begin{array}{l}\text { cis-DCE, } \\
\mu \mathrm{g} / \mathrm{kg}\end{array}$ & $\begin{array}{l}\text { TCE, } \\
\text { gross }\end{array}$ & $\begin{array}{l}\text { TCE, } \\
\mu \mathrm{g} / \mathbf{k g}\end{array}$ \\
211 & 3.0 & 3.80 & 1x & ND & ND & 178 & 234 \\
212 & 7.0 & 3.73 & $10 \mathrm{x}$ & ND & ND & 4864 & 6520 \\
213 & 12.0 & 3.63 & $1000 \mathrm{x}$ & ND & ND & 160,615 & 221,233 \\
214 & 17.0 & 3.06 & $100 \mathrm{x}$ & ND & ND & 21,751 & 35,541 \\
215 & 22.0 & 3.56 & $10 \mathrm{x}$ & ND & ND & 9188 & 12,904 \\
216 & 27.0 & 4.24 & $10 \mathrm{x}$ & ND & ND & 25,446 & 30,007 \\
\end{tabular}

D: soil sample duplicate

W: groundwater sample (denoted by italics and shading)

NA: not applicable

ND: not detected 


\section{E-9}

\section{Post-treatment samples from T7 Cell}

Post-T7B1

\begin{tabular}{llllllll}
\hline Sample & Depth & Weight, g & Dilution & $\begin{array}{l}\text { cis-DCE, } \\
\text { gross }\end{array}$ & $\begin{array}{l}\text { cis-DCE, } \\
\mu \mathrm{g} / \mathrm{kg}\end{array}$ & $\begin{array}{l}\text { TCE, } \\
\text { gross }\end{array}$ & $\begin{array}{l}\text { TCE, } \\
\mu \mathrm{g} / \mathbf{k g}\end{array}$ \\
204 & 1.0 & 2.78 & $1 \mathrm{x}$ & $\mathrm{ND}$ & $\mathrm{ND}$ & 1157 & 2081 \\
205 & 3.0 & 3.29 & $1 \mathrm{x}$ & $\mathrm{ND}$ & $\mathrm{ND}$ & 1202 & 1827 \\
206 & 7.0 & 3.25 & $10 \mathrm{x}$ & ND & ND & 2355 & 3623 \\
207 & 12.0 & 3.42 & $10 \mathrm{x}$ & ND & ND & 11,792 & 17,240 \\
208 & 17.0 & 3.60 & $10 \mathrm{x}$ & ND & ND & 6271 & 8710 \\
209 & 22.0 & 3.87 & $10 \mathrm{x}$ & ND & ND & 3228 & 4171 \\
210 & 27.0 & 4.43 & $10 \mathrm{x}$ & ND & ND & 1166 & 1316
\end{tabular}

Post-T7B2

\begin{tabular}{llllllll}
\hline Sample & Depth & Weight, g & Dilution & $\begin{array}{l}\text { cis-DCE, } \\
\text { gross }\end{array}$ & $\begin{array}{l}\text { cis-DCE, } \\
\mu \mathrm{g} / \mathrm{kg}\end{array}$ & $\begin{array}{l}\text { TCE, } \\
\text { gross }\end{array}$ & $\begin{array}{l}\text { TCE, } \\
\mu \mathrm{g} / \mathrm{kg}\end{array}$ \\
197 & 1.0 & 3.59 & $10 \mathrm{x}$ & ND & ND & 1365 & 1901 \\
198 & 3.0 & 3.79 & $10 \mathrm{x}$ & ND & ND & 686 & 905 \\
199 & 7.0 & 3.63 & $10 \mathrm{x}$ & ND & ND & 1329 & 1831 \\
200 & 12.0 & 3.69 & $100 \mathrm{x}$ & ND & ND & 12,111 & 16,411 \\
201 & 17.0 & 4.09 & $10 \mathrm{x}$ & ND & ND & 9336 & 11,413 \\
202 & 22.0 & 4.37 & $10 \mathrm{x}$ & ND & ND & 3945 & 4514 \\
203 & 27.0 & 4.65 & $10 \mathrm{x}$ & ND & ND & 1846 & 1985
\end{tabular}

Post-T7B3

\begin{tabular}{llllllll}
\hline Sample & Depth & Weight, g & Dilution & $\begin{array}{l}\text { cis-DCE, } \\
\text { gross }\end{array}$ & $\begin{array}{l}\text { cis-DCE, } \\
\mu \mathrm{g} / \mathrm{kg}\end{array}$ & $\begin{array}{l}\text { TCE, } \\
\text { gross }\end{array}$ & $\begin{array}{l}\text { TCE, } \\
\mu \mathrm{g} / \mathrm{kg}\end{array}$ \\
190 & 1.0 & 2.94 & $1 \mathrm{x}$ & ND & ND & 924 & 1571 \\
191 & 3.0 & 3.38 & $1 \mathrm{x}$ & ND & ND & 668 & 988 \\
192 & 7.0 & 4.12 & $10 \mathrm{x}$ & ND & ND & 1087 & 1319 \\
193 & 12.0 & 3.83 & $10 \mathrm{x}$ & ND & ND & 1603 & 2093 \\
194 & 17.0 & 4.02 & $10 \mathrm{x}$ & ND & ND & 4846 & 6027 \\
195 & 22.0 & 3.70 & $10 \mathrm{x}$ & ND & ND & 1834 & 2478 \\
196 & 27.0 & 3.86 & $10 \mathrm{x}$ & ND & ND & 3076 & 3984 \\
& & & & & & & \\
\hline
\end{tabular}

D: soil sample duplicate

W: groundwater sample (denoted by italics and shading)

NA: not applicable

ND: not detected 


\author{
APPENDIX F \\ Implementation of Deep Soil Mixing Innovative Remedial Technology \\ at the Kansas City Plant \\ Chemical Oxidation Laboratory Treatability Study Results
}


Implementation of Deep Soil Mixing Innovative Remedial Technology at

the Kansas City Plant

Chemical Oxidation Laboratory Treatability Study Results

\author{
D.D. Gates ${ }^{1}$ \\ R.L. Siegrist ${ }^{1}$ \\ S.R. Cline ${ }^{1}$
}

November 1995

${ }^{1}$ Oak Ridge National Laboratory, Oak Ridge, TN 37831 


\section{Implementation of Deep Soil Mixing Innovative Remedial Technology \\ at \\ the Kansas City Plant}

Chemical Oxidation Laboratory Treatability Study Results

\section{Objective}

The objective of the chemical oxidation treatability studies was to determine if chemical oxidation treatment can be used to degrade DCE and TCE in contaminated soil from the DOE Kansas City Plant. The study objective was met by conducting three series of experiments 1)effect of oxidant type and concentration studies; 2)effect of oxidant volume studies and 3)oxidant persistence and effect on soil composition study. The first two studies were completed using zero-headspace extraction vessels loaded with either field or artificially contaminated soil from the Kansas City Plant. Oxidant solution(s) were added to the contaminated soil under gas-tight conditions and pre- and posttreatment contaminant concentrations were measured to determine chemical oxidation treatment efficiency. The final series of experiments was completed using a laboratory-scale soil mixing apparatus designed to replicate reagent injection and deep soil mixing.

\section{Effect of Oxidant Type}

In this study, field contaminated Kansas City soil was treated with either $\mathrm{KMnO}_{4}, \mathrm{H}_{2} \mathrm{O}_{2}$, or $\mathrm{H}_{2} \mathrm{O}_{2}$ supplemented with $\mathrm{FeSO}_{4}$. A KMnO 4 concentration of $4 \%$ (wt basis) was selected for this study after considering the solubility of $\mathrm{KMnO}_{4}$ at room temperature $(\sim 6 \%)$, and the expected purity of bulk (technical grade) $\mathrm{KMnO}_{4} . \mathrm{A} \mathrm{H}_{2} \mathrm{O}_{2}$ concentration of $8.5 \%$ (wt basis) was selected so that the handling concerns and hazards associated with higher concentration $\mathrm{H}_{2} \mathrm{O}_{2}$ solutions could be avoided. During this initial screening study, only the reduction in TCE from a pre-treatment concentration of $14 \mathrm{mg} / \mathrm{kg}$ was evaluated. In Figure 1, the TCE removals obtained when the same volume $(8 \mathrm{~mL})$ of oxidant solution was added to $28 \mathrm{~g}$ of field moist soil are shown. The greatest TCE reduction (96.1\%) was achieved when the soil was treated with the $\mathrm{KMnO}_{4}$ solution. TCE reductions achieved with $\mathrm{H}_{2} \mathrm{O}_{2}$ and $\mathrm{H}_{2} \mathrm{O}_{2}+$ iron were $40.4 \%$ and $72.5 \%$ respectively. The improvement in $\mathrm{H}_{2} \mathrm{O}_{2}$ treatment observed with iron supplementation was probably due to the catalytic effect $\mathrm{Fe}^{2+}$ has on the decomposition of $\mathrm{H}_{2} \mathrm{O}_{2}$ to the hydroxyl radical (Fenton's process). 


$$
\text { F-2 }
$$

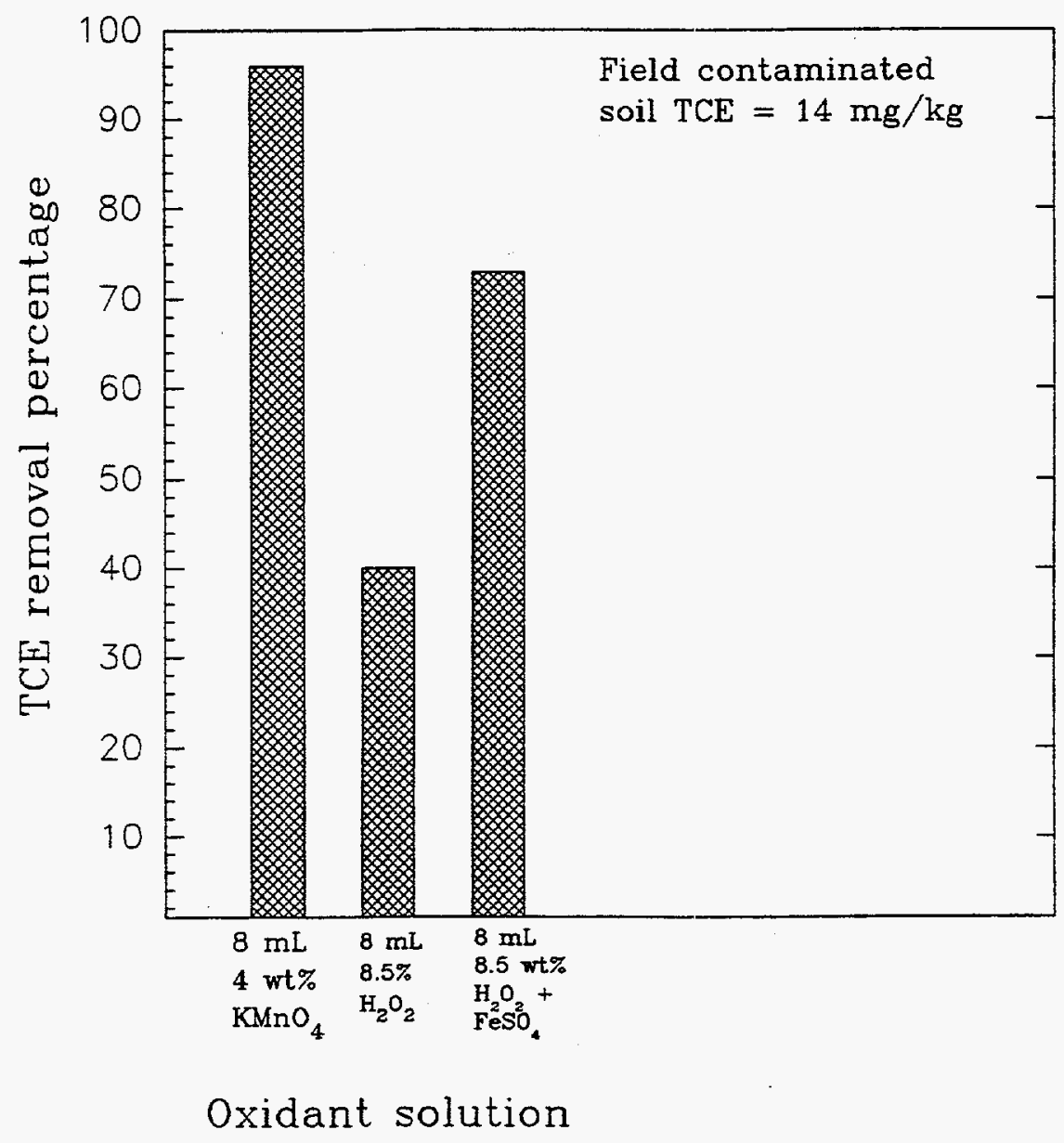

Figure 1. TCE removal from field contaminated soil 


$$
\mathrm{F}-3
$$

\section{Effect of $\mathrm{KMnO}_{4}$ Concentration}

Because $\mathrm{KMnO}_{4}$ appeared to be the most promising chemical oxidant for field application, all additional experiments in this treatability study were conducted using only $\mathrm{KMnO}_{4}$ solutions. Additional studies completed using soil from another DOE site suggest that the $\mathrm{H}_{2} \mathrm{O}_{2}$ treatment levels can be further improved by adjusting the supplemental iron dose or using multiple $\mathrm{H}_{2} \mathrm{O}_{2}$ treatments. A more complete evaluation of $\mathrm{H}_{2} \mathrm{O}_{2}$ treatment of contaminated Kansas City soil can be completed in the future if needed.

Soil from field contaminated soil core number 269 was treated with several different concentrations of $\mathrm{KMnO}_{4}$ solution. This experiment was completed to determine if the demonstration objectives could be met using lower $\mathrm{KMnO}_{4}$ concentrations than those used in the previously described experiment. For this experiment, soil slurries (1:1, soil:water) were formed from the field contaminated soil, prior to oxidant addition. Soil slurries were used in this studies to ensure that complete mixing was achieved during treatment. The results of this study are plotted in Figure 2. It was observed that the TCE treatment efficiency increased as the oxidant concentration was increased from a low value of $34.9 \%$ removal with $0.5 \% \mathrm{KMnO}_{4}$ to a high of $95.6 \%$ removal with $4 \% \mathrm{KMnO}_{4}$ from an initial TCE concentration of $349 \mathrm{mg} / \mathrm{kg}$. The proposed demonstration goal of $>70 \%$ contaminant reductions was exceeded at the two highest $\mathrm{KMnO}_{4}$ concentration evaluated for TCE. DCE removals of $100 \%$ from an initial concentration of $12 \mathrm{mg} / \mathrm{kg}$ was observed at all $\mathrm{KMnO}_{4}$ concentrations.

The effect of $\mathrm{KMnO}_{4}$ concentration experiment was repeated with soil slurries artificially contaminated with TCE. This was done to determine if uncontaminated Kansas City soil could be artificially contaminated and used in latter studies. The results of this experiment are also shown in Figure 2. The agreement observed between the treatment achieved in the field contaminated and artificially contaminated soil is quite good. The same trends were observed in both soil, although a significant difference $(>20 \%)$ was found in the soils treated with the lowest concentration $\mathrm{KMnO}_{4}$ solution. At the higher $\mathrm{KMnO}_{4}$ concentrations, which are more relevant to the proposed field application, the agreement in results between field and artificially contaminated soil is less than $10 \%$.

\section{Effect of oxidant volume}

This series of experiments was conducted to determine if the volume of oxidant solution added to the contaminated soil could be minimized or eliminated by treating the soil with greater than $4 \% \mathrm{KMnO}_{4}$ solutions or treating the soil with $\mathrm{KMnO}_{4}$ crystals. Field contaminated soil from core number 270 was treated with $5 \%, 8 \%$ and $12 \% \mathrm{KMnO} 4$ solutions or dry $\mathrm{KMnO}_{4}$ crystals. An additional series of experiments was completed with artificially contaminated Kansas City, since the initial contaminant concentrations in the field contaminated soil had decreased during storage. 


$$
\mathrm{F}-4
$$

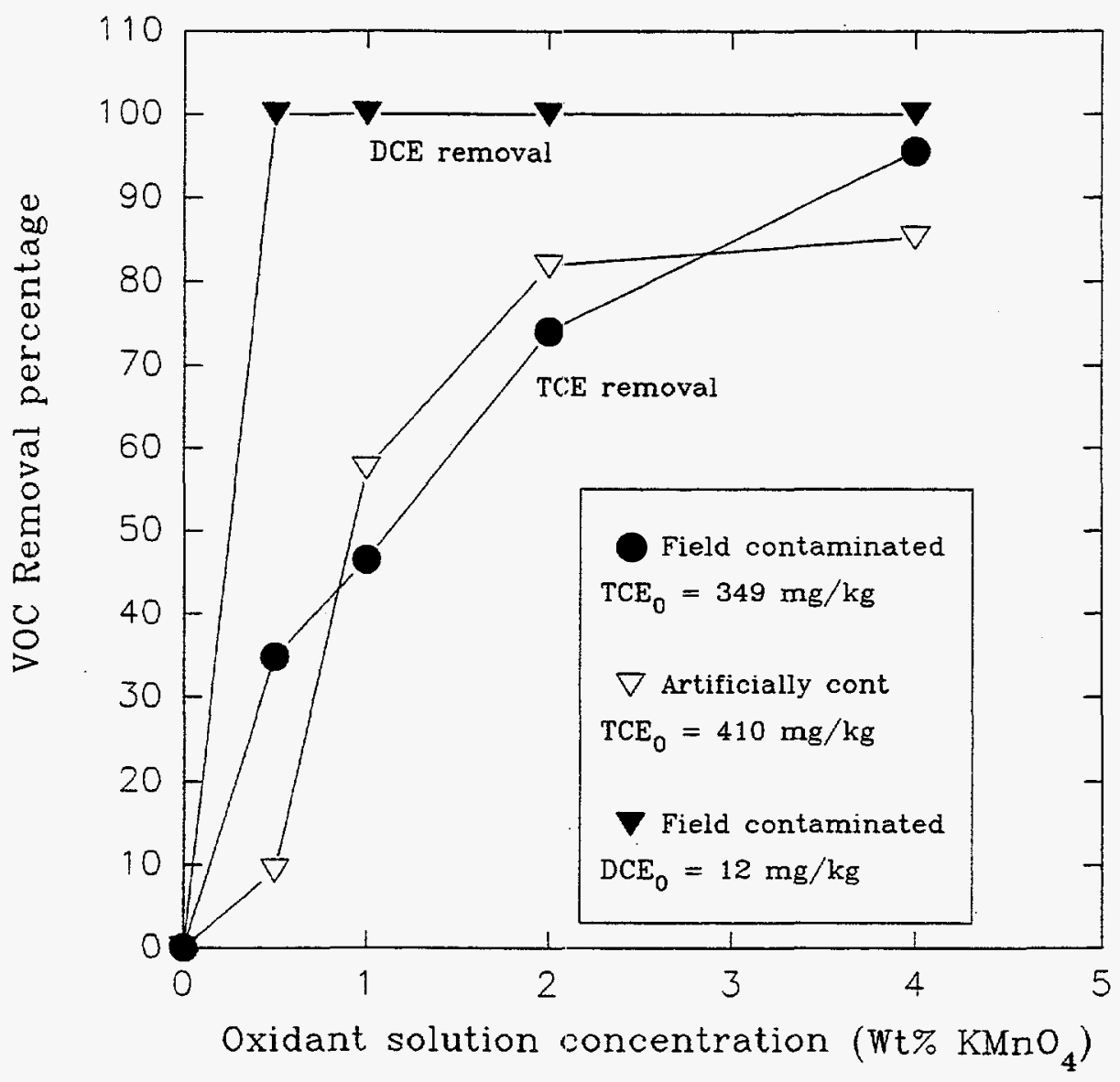

Figure 2. VOC reduction in contaminated soil slurries treated with $\mathrm{KMnO}_{4}$ solution. ( $8 \mathrm{~mL}$ of oxidant solution added to $40 \mathrm{~g}$ of soil slurry) 
During these experiments, field moist soils (no slurries) were treated in zero-headspace extraction vessels. The volume of oxidant solution and the mass of $\mathrm{KMnO}_{4}$ crystals added to the soil were selected so that roughly equivalent doses $\left(20 \mathrm{~g} \mathrm{KMnO}_{4} / \mathrm{kg}\right.$ soil $)$ of oxidant were added to the soils during treatment. The volume of $5 \%, 8 \%$ and $12 \% \mathrm{KMnO}_{4}$ solution added to the soil was 8,4 , and $3 \mathrm{~mL}$ respectively. The $\mathrm{KMnO}_{4}$ solutions with concentrations greater than $6 \%$ had to be prepared by heating the $\mathrm{KMnO}_{4} /$ water solution to a temperature of approximately $40^{\circ} \mathrm{C}$. The results of this study are shown in Figures 3 and 4. With all of the higher strength oxidant solutions, greater than $85 \%$ TCE removal (initial TCE $=536 \mathrm{mg} / \mathrm{kg}$ artificially contaminated, $14 \mathrm{mg} / \mathrm{kg}$ field contaminated) and $100 \%$ DCE removal (initial DCE $=124 \mathrm{mg} / \mathrm{kg}$ artificially contaminated, $9.7 \mathrm{mg} / \mathrm{kg}$ field contaminated) was observed. Although it may not be feasible to prepare higher concentration $\mathrm{KMnO}_{4}$ solutions in the field, these experiments suggest that the demonstration objectives could be met by adding lower volumes of higher concentration oxidant solution. The advantages of adding lower volumes of oxidant include less potential to form a structurally unstable slurry in situ and decreased possibility of oxidant solutions and/or contaminants migrating from the treatment zone.

\section{$\mathrm{KMnO}_{4}$ Persistence in Field Moist Soil}

One final series of experiments was completed to determine the persistence of $\mathrm{KMnO}_{4}$ in field moist soil. In this experiments, uncontaminated Kansas City soil (field moist) was mixed with 3 different volumes of $4 \mathrm{wt} \% \mathrm{KMnO}_{4}$ using a laboratory-scale soil mixing apparatus. The volume of oxidant solution applied to the soil were $0.05,0.1$, and $0.15 \mathrm{~mL}$ oxidant $/ \mathrm{g}$ soil $\left(0.6,1.2\right.$, and $\left.1.8 \mathrm{gal} / \mathrm{ft}^{3}\right)$. These volumetric loadings correspond to oxidant additions to the soil of 5,10 and $15 \%$ on a weight basis (weight oxidant to weight of soil treated). Oxidant solutions were mixed directly into soil packed into 6 inch brass sleeves using a 2.5 inch diameter mixing blade. This arrangement allowed the field auger mixing and oxidant injection process to be evaluated at the laboratory scale. Soil samples were collected at regular intervals after oxidant addition so the moisture content and oxidant concentration could be monitored.

The increase in moisture content observed after oxidant addition correlated well with the volumes of oxidant added. The soil moisture content increased from an average pretreatment value of $25.2 \%$ to values of $25.5,27.8$ and $29.9 \%$ for the soils treated with $0.05,0.1$, and $0.15 \mathrm{~mL}$ oxidant/g soil respectively. The moisture content of the treated soils decreased with time. Seven days after oxidant injection the moisture content of the soils treated with 0.1 and $0.15 \mathrm{~mL}$ oxidant/g soil oxidant injections were only 4.5 and $11.4 \%$ greater than the pretreatment value.

The oxidant concentration following injection and mixing was also evaluated to determine how long $\mathrm{KMnO}_{4}$ could remain "active" in the Kansas City soil. After soil samples were collected from the treated cores, the soil solution was extracted (by the addition of $20 \mathrm{~mL}$ DI $\mathrm{H}_{2} \mathrm{O}$ ). The $\mathrm{KMnO}_{4}$ concentrations in these extracts were measured colorimetrically. In the soils treated with 0.05 and $0.1 \mathrm{~mL} / \mathrm{g}$, the $\mathrm{KMnO}_{4}$ concentration decreased by over 


$$
\mathrm{F}-6
$$

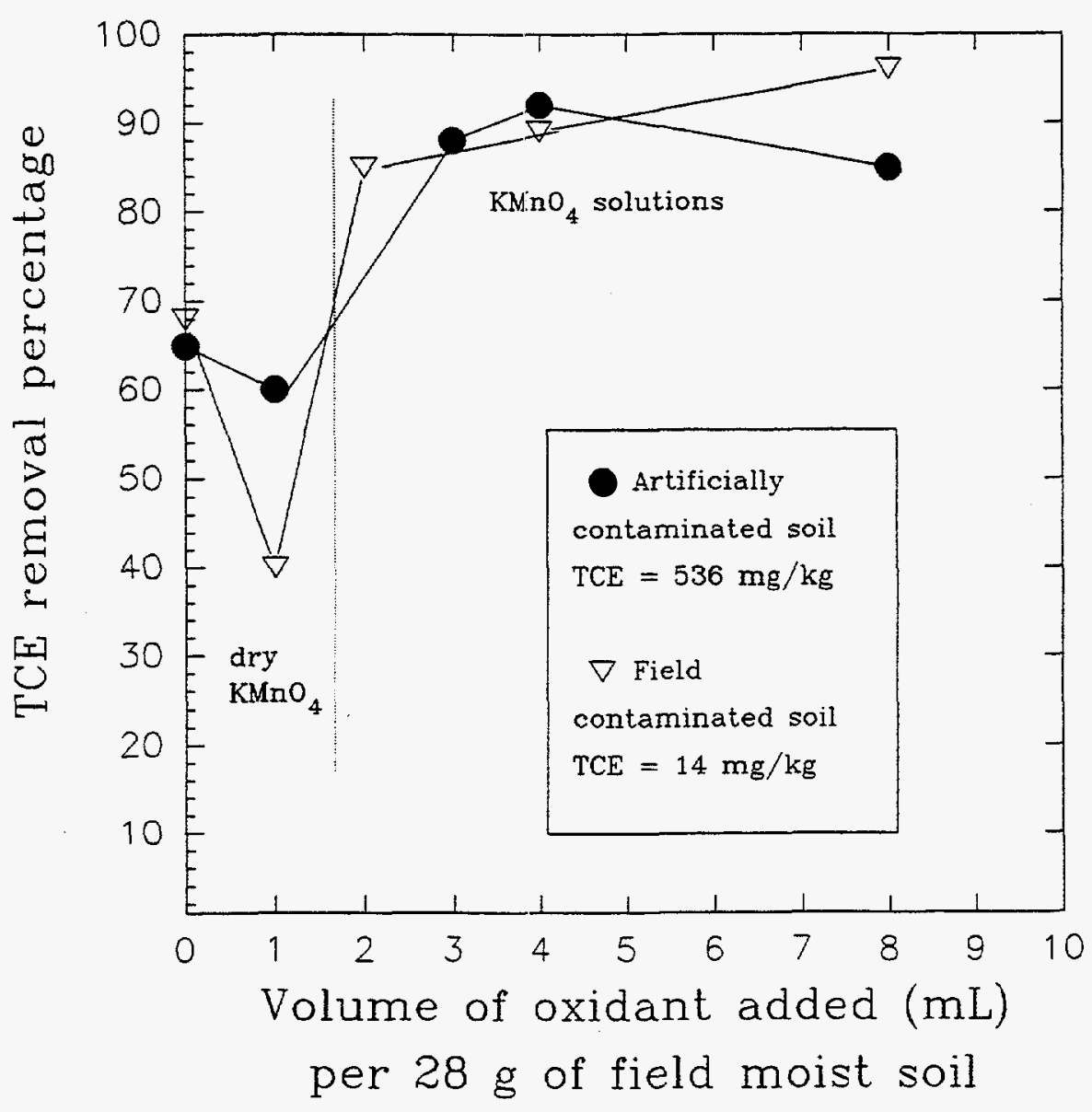

Figure 3.- TCE reduction in soil treated with different volumes of oxidant solution. Note: The oxidant concentration was varied from 5 to $12 \% \mathrm{KMnO}_{4}$ in order to maintain an oxidant loading of $20 \mathrm{~g} \mathrm{KMnO}_{4} / \mathrm{kg}$ soil treated. 


$$
\text { F-7 }
$$

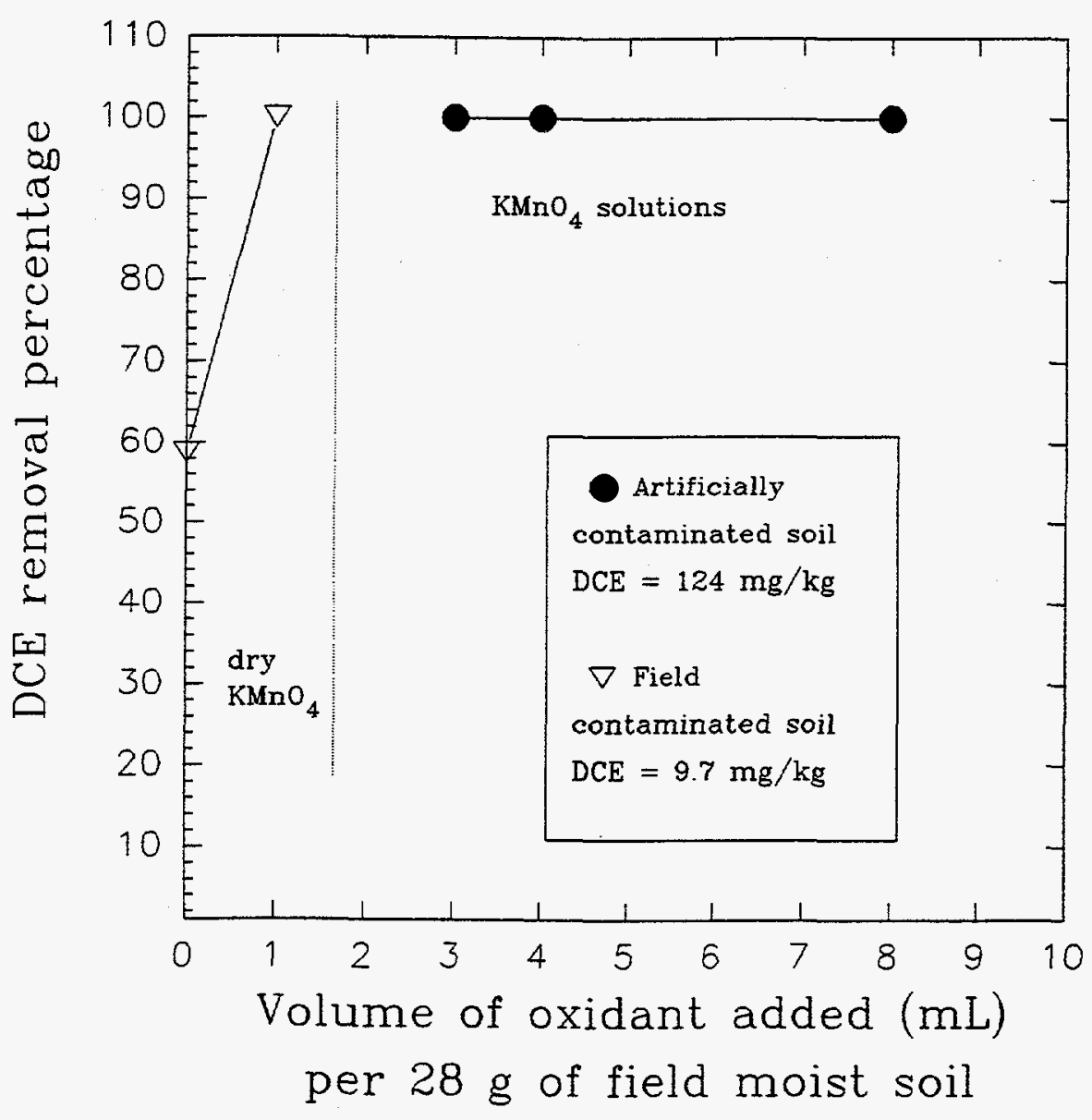

Figure 4. DCE reduction in soil treated with different volumes of oxidant solution.

Note: The oxidant concentration was varied from 5 to $12 \% \mathrm{KMnO}_{4}$ in order to maintain an oxidant loading of $20 \mathrm{~g} \mathrm{KMnO}_{4} / \mathrm{kg}$ soil treated. 
$98 \%$ to 0.005 and $0.24 \mathrm{~g} / \mathrm{kg}$ within 20 minutes of oxidant addition, indicating the rapid consumption of $\mathrm{KMnO}_{4}$ in the soil. The soil treated with the higher volume of $\mathrm{KMnO}_{4}$ had higher $\mathrm{KMnO}_{4}$ concentrations after 20 minutes $(1.1 \mathrm{~g} / \mathrm{kg})$. One day after oxidant injection no residual $\mathrm{KMnO}_{4}$ was detected in the soils treated with 0.05 and $0.1 \mathrm{~mL} / \mathrm{g}$ $\mathrm{KMnO}_{4}$. The $\mathrm{KMnO}_{4}$ residual in the soil treated with $0.15 \mathrm{~mL} / \mathrm{g}$ of $\mathrm{KMnO}_{4}$ was 0.013 and $0.02 \mathrm{~g} \mathrm{KMnO}_{4} / \mathrm{kg}$ soil 1 and 7 days after oxidant injection, respectively.

\section{Conclusions}

- $\mathrm{KMnO}_{4}$ is more effective an oxidant than $\mathrm{H}_{2} \mathrm{O}_{2}$ or $\mathrm{H}_{2} \mathrm{O}_{2}$ tiron for the removal of TCE and DCE in contaminated soils from the Kansas City Plant.

- Under all but one of the experimental conditions evaluated, $100 \%$ of the DCE (initial concentration $12-124 \mathrm{mg} / \mathrm{kg}$ ) was removed from the Kansas City soil. Less the $100 \%$ DCE removal was observed in the soil treated with crystalline $\mathrm{KMnO}_{4}$.

- With $\mathrm{KMnO}_{4}$ concentration of at least $4 \%$ and oxidant loading greater than $16 \mathrm{mg}$ $\mathrm{KMnO}_{4} / \mathrm{kg}$ soil, TCE removals greater than $90 \%$ are possible.

- The volume of oxidant solution that is required to treat the Kansas City soil can be reduced by increasing the concentration of oxidant solution. In order to prepare solutions with $\mathrm{KMnO}_{4}$ concentrations greater than $6 \%$ (by weight) the oxidant solution needs to be heated to $40^{\circ} \mathrm{C}$.

- It is possible to treat the contaminated soil with crystalline $\mathrm{KMnO}_{4}$, however, TCE reductions are significantly lower that those achieved in soils treated with $\mathrm{KMnO}_{4}$ solutions.

- $\mathrm{KMnO}_{4}$ addition increases soil moisture content by an amount proportional to the oxidant volume and slightly increases soil $\mathrm{pH}$. Additional studies would be required to determine the effect of $\mathrm{KMnO}_{4}$ addition on the soil microbial population. 
APPENDIX G

$\mathrm{KMnO}_{4}$ Loading Rate Calculations for T5 and T4 Cells 
$\mathrm{KMnO}_{4}$ Loading Rate Calculations for $\mathrm{T} 5$ and $\mathrm{T} 4$ cells

T5 cell

Assumptions: Each cell is 8 by $25 \mathrm{ft}$ cylinder $(243.84 \mathrm{~cm}$ by $762 \mathrm{~cm})$

C2 cell overlaps $60 \%$, yielding a net $40 \%$ for volume calc.

Particle density $=2.65 \mathrm{~g} / \mathrm{cm}^{3}$

Effective porosity $=30 \%$

$25640 \mathrm{~L}$ of $\mathrm{KMnO}_{4} @ 4.2 \%=(25,640 \mathrm{~L})(42,000 \mathrm{mg} / \mathrm{L})=$ $1,076,880 \mathrm{~g} \mathrm{KMnO}_{4}$

Volume Calc:

Volume of 1 column $=3.14(122 \mathrm{~cm})^{2} \times 762 \mathrm{~cm}$

$$
=35,612,649 \mathrm{~cm}^{3}
$$

Volume of $\mathrm{C} 2$ column $=35,612,649 \mathrm{~cm}^{3}(.4)$

$$
=14,245,060 \mathrm{~cm}^{3}
$$

Total volume of $\mathrm{C} 1, \mathrm{C} 2$ and $\mathrm{C} 3=35,612,649 \mathrm{~cm}^{3} \times 2+14,245,060 \mathrm{~cm}^{3}$

$$
=85,470,358 \mathrm{~cm}^{3}
$$

Subtract $30 \%$ for effective porosity $=85,470,358 \mathrm{~cm}^{3} \quad(.3)$

$$
=59,829,251 \mathrm{~cm}^{3}
$$

Multiply by bulk density $=59,829,251 \mathrm{~cm}^{3} \times 2.65 \mathrm{~g} / \mathrm{cm}^{3}$

$$
\begin{aligned}
& =158,547,515 \mathrm{~g} \times 10^{-3} \\
& =158,547.5 \mathrm{~kg} \text { of soil }
\end{aligned}
$$

$\mathrm{KMnO}_{4}$ Loading Calc: $1,076,880 \mathrm{~g} \mathrm{KMnO}_{4} / 158,547.5 \mathrm{~kg}$ soil $=\mathbf{6 . 7 9} \mathbf{g}$ $\mathrm{KMnO}_{4} / \mathbf{k g}$ soil

Substituting particle density with a total bulk density of $1.75 \mathrm{~g} / \mathrm{cm}^{3}$ which accounts for void space and moisture content $(28 \%)$ produces a loading rate of: $7.2 \mathrm{~g} \mathrm{KMnO}_{4} / \mathrm{kg}$ soil.

\section{T5C1 column}

$35,612,649 \mathrm{~cm}^{3}-30 \% \times 2.65 \mathrm{~g} / \mathrm{cm}^{3}=66,061,464 \mathrm{~g}=66,061.5 \mathrm{~kg}$ $7380 \mathrm{~L} \times 37,000 \mathrm{mg} / \mathrm{L}=273,060,000 \mathrm{mg}=273,060 \mathrm{~g} \mathrm{KMnO}_{4}$ $273,060 \mathrm{~g} \mathrm{KMnO}_{4} / 66,061.5 \mathrm{~kg}$ soil $=4.13 \mathbf{g ~ K M n O}_{4} / \mathbf{k g}_{\text {soil }}$ 


\section{T5C3 column}

$35,612,649 \mathrm{~cm}^{3}-30 \% \times 2.65 \mathrm{~g} / \mathrm{cm}^{3}=66,061,464 \mathrm{~g}=66,061.5 \mathrm{~kg}$ $14,000 \mathrm{~L} \times 47,000 \mathrm{mg} / \mathrm{L}=658,000,000 \mathrm{mg}=658,000 \mathrm{~g} \mathrm{KMnO}_{4}$ $658,000 \mathrm{~g} \mathrm{KMnO}_{4} / 66,061.5 \mathrm{~kg}$ soil $=9.96 \mathbf{g ~ K M n O}_{4} / \mathrm{kg}$ soil

\section{T5C2 column}

The overlap of the $\mathrm{C} 2$ column necessitates different treatment to calculate $\mathrm{KMnO}_{4}$ loading rate. Essentially $30 \%$ of the $\mathrm{C} 2$ column overlaps the $\mathrm{C} 1$ column and $30 \%$ overlaps the $\mathrm{C} 3$ column. Using $30 \%$ of the total mass of each of these columns yields $19,818 \mathrm{~kg}(66,061.5 \mathrm{~kg}-30 \%=19,818 \mathrm{~kg}$ soil). Thus, $19,818 \mathrm{~kg}$ soil in the overlap region with $\mathrm{Cl}$ column has $4.13 \mathrm{~g} \mathrm{KMnO}_{4}$ per $\mathrm{kg} /$ soil and $19,818 \mathrm{~kg}$ soil in the overlap region with $\mathrm{C} 3$ columa has $9.96 \mathrm{~kg} \mathrm{KMnO}_{4}$ per $\mathrm{kg}$ soil. This translates to:

$4.13 \mathrm{~g} \mathrm{KMnO}_{4} / \mathrm{kg}$ soil $\times 19,818 \mathrm{~kg} \mathrm{soil}=81,848 \mathrm{~g} \mathrm{KMnO}_{4}$ in the $\mathrm{C} 1 / \mathrm{C} 2$ overlap region before $\mathrm{C} 2$ is mixed

$9.96 \mathrm{~g} \mathrm{KMnO}_{4} / \mathrm{kg}$ soil $\times 19,818 \mathrm{~kg}$ soil $=197,387 \mathrm{~g} \mathrm{KMnO}_{4}$ in the $\mathrm{C} 1 / \mathrm{C} 3$ overlap region before $\mathrm{C} 2$ is mixed

During the $\mathrm{C} 2$ mixing $4260 \mathrm{~L} \mathrm{KMnO}_{4}$ at $4.2 \%\left(178,920 \mathrm{~g} \mathrm{KMnO}_{4}\right)$ was mixed in with $66,061.5 \mathrm{~kg}$ soil which yields a loading rate of $2.71 \mathrm{~g} \mathrm{KMnO}_{4} / \mathrm{kg}$ soil in $\mathrm{C} 2$. Therefore, the overlap regions have received an additional $2.71 \mathrm{~g} \mathrm{KMnO}_{4}$ per $\mathrm{kg}$ soil:

$2.71 \mathrm{~g} \mathrm{KMnO}_{4} / \mathrm{kg}$ soil $\times 19,818 \mathrm{~kg}$ soil $=53,707 \mathrm{~g} \mathrm{KMnO}_{4}$ $53,707 \mathrm{~g} \mathrm{KMnO}_{4}$ must be added to the $\mathrm{C} 1$ and $\mathrm{C} 3$ overlap regions to determine the total $\mathrm{KMnO}_{4}$ added:

$53,707 \mathrm{~g} \mathrm{KMnO}_{4}+81,848 \mathrm{~g} \mathrm{KMnO}_{4}$ in the $\mathrm{Cl} / \mathrm{C} 2$ overlap region $=135,555 \mathrm{~g}$ total in the $\mathrm{C} 2 / \mathrm{C} 1$ overlap region

$53,707 \mathrm{~g} \mathrm{KMnO}_{4}+197,387 \mathrm{~g} \mathrm{KMnO}_{4}$ in the $\mathrm{Cl} / \mathrm{C} 3$ overlap region $=251,994 \mathrm{~g}$ total in the $\mathrm{C} 2 / \mathrm{C} 3$ overlap region

Loading rate for $\mathrm{C} 2$ calculated as follows:

$\mathrm{C} 2 / \mathrm{C} 1$ overlap region: $135,555 \mathrm{~g} \mathrm{KMnO}_{4} / 19,818 \mathrm{~kg}$ soil $=6.84 \mathrm{~g} \mathrm{KMnO}_{4} / \mathrm{kg}$ soil $\mathrm{C} 2 / \mathrm{C} 3$ overlap region: $251,994 \mathrm{~g} \mathrm{KMnO}_{4} / 19,818 \mathrm{~kg}$ soil $=12.72 \mathrm{~g} \mathrm{KMnO}_{4} / \mathrm{kg}$ soil $\mathrm{C} 2$ nonoverlap area is $2.71 \mathrm{~g} \mathrm{KMnO}_{4} / \mathrm{kg}$ soil 
Weighted average loading rate for the $\mathrm{C} 2$ column: (30\%) $6.84 \mathrm{~g}+(30 \%) 12.72 \mathrm{~g}$ $+(40 \%) 2.71 \mathrm{~g}=6.85 \mathrm{~g} \mathrm{KMnO}_{4} / \mathrm{kg}$ soil

\section{T4 Cell}

Assumptions: Each cell is 8 by $47 \mathrm{ft}$ cylinder $(243.84 \mathrm{~cm}$ by $1433 \mathrm{~cm})$

C2 cell overlaps $60 \%$, yielding a net $40 \%$ for volume calc.

Particle density $=2.65 \mathrm{~g} / \mathrm{cm}^{3}$

Effective porosity $=30 \%$

41399 of $\mathrm{KMnO}_{4} @ 3.8 \%=(41,399 \mathrm{~L})(38,000 \mathrm{mg} / \mathrm{L})=$ $1,573,162 \mathrm{~g} \mathrm{KMnO}_{4}$

Volume Calc:

Volume of 1 column $=3.14(122 \mathrm{~cm})^{2} \times 1433 \mathrm{~cm}$

$$
=66,972,344 \mathrm{~cm}^{3}
$$

Volume of $\mathrm{C} 2$ column $=66,972,344 \mathrm{~cm}^{3}(.4)$

$$
=26,788,938 \mathrm{~cm}^{3}
$$

Total volume of $\mathrm{C} 1, \mathrm{C} 2$ and $\mathrm{C} 3=66,972,344 \mathrm{~cm}^{3}(2)+26,788,938 \mathrm{~cm}^{3}$

$$
=160,733,626 \mathrm{~cm}^{3}
$$

Subtract $30 \%$ for effective porosity $=160,733,626 \mathrm{~cm}^{3}$

$$
=112,513,538 \mathrm{~cm}^{3}
$$

Multiply by bulk density $=112,513,538 \mathrm{~cm}^{3} \times 2.65 \mathrm{~g} / \mathrm{cm}^{3}$

$$
\begin{aligned}
& =298,160,876 \mathrm{~g} \times 10^{-3} \\
& =\mathbf{2 9 8 , 1 6 0 . 9} \mathrm{kg} \text { of soil }
\end{aligned}
$$

$\mathrm{KMnO}_{4}$ Loading Calc: $1,573,162 \mathrm{~g} \mathrm{KMnO}_{4} / 298,160.9 \mathrm{~kg}$ soil $=5.28 \mathrm{~g}$ $\mathrm{KMnO}_{4} / \mathrm{kg}$ soil

Substituting particle density with a total bulk density of $1.75 \mathrm{~g} / \mathrm{cm}^{3}$ which accounts for void space and moisture content $(28 \%)$ produces a loading rate of: $5.6 \mathrm{~g} \mathrm{KMnO}_{4} / \mathrm{kg}$ soil. 


\section{T4C1 column}

$66,972,344 \mathrm{~cm}^{3}-30 \% \times 2.65 \mathrm{~g} / \mathrm{cm}^{3}=124,233,698 \mathrm{~g}=124,233.7 \mathrm{~kg}$ $14,570 \mathrm{~L} \times 31,000 \mathrm{mg} / \mathrm{L}=451,670,000 \mathrm{mg}=451,670 \mathrm{~g} \mathrm{KMnO}_{4}$ $451,670 \mathrm{~g} \mathrm{KMnO}_{4} / 124,233.7 \mathrm{~kg}$ soil $=3.64 \mathbf{g ~ K M n O}_{4} / \mathrm{kg}$ soil

\section{T4C3 column}

$66,972,344 \mathrm{~cm}^{3}-30 \% \times 2.65 \mathrm{~g} / \mathrm{cm}^{3}=124,233,698 \mathrm{~g}=124,233.7 \mathrm{~kg}$ $15,140 \mathrm{~L} \times 49,000 \mathrm{mg} / \mathrm{L}=741,860,000 \mathrm{mg}=741,860 \mathrm{~g} \mathrm{KMnO}_{4}$ $741,860 \mathrm{~g} \mathrm{KMnO}_{4} / 124,233.7 \mathrm{~kg}$ soil $=5.97 \mathbf{g ~ K M n O}_{4} / \mathbf{k g}$ soil

\section{T4C2 column}

The overlap of the $\mathrm{C} 2$ column necessitates different treatment to calculate $\mathrm{KMnO}_{4}$ loading rate. Essentially $30 \%$ of the $C 2$ column overlaps the $C 1$ column and $30 \%$ overlaps the C3 column. Using $30 \%$ of the total mass of each of these columns yields $37,270 \mathrm{~kg}(124,233.7 \mathrm{~kg} \times 30 \%=37,270 \mathrm{~kg}$ soil). Thus $37,270 \mathrm{~kg}$ soil in the overlap region with $\mathrm{C} 1$ column has $3.64 \mathrm{~g} \mathrm{KMnO}_{4}$ per $\mathrm{kg} / \mathrm{soil}$ and $37,270 \mathrm{~kg}$ soil in the overlap region with $\mathrm{C} 3$ column has $5.97 \mathrm{~kg} \mathrm{KMnO}_{4}$ per $\mathrm{kg}$ soil. This translates to:

$3.64 \mathrm{~g} \mathrm{KMnO}_{4} / \mathrm{kg}$ soil $\times 37,270 \mathrm{~kg}$ soil $=135,663 \mathrm{~g} \mathrm{KMnO}_{4}$ in the $\mathrm{C} 1 / \mathrm{C} 2$ overlap region before $\mathrm{C} 2$ is mixed

$5.97 \mathrm{~g} \mathrm{KMnO}_{4} / \mathrm{kg}$ soil $\times 37,270 \mathrm{~kg}$ soil $=222,502 \mathrm{~g} \mathrm{KMnO}_{4}$ in the $\mathrm{C} 1 / \mathrm{C} 3$ overlap region before $\mathrm{C} 2$ is mixed

During the $\mathrm{C} 2$ mixing $11,689 \mathrm{~L} \mathrm{KMnO}_{4}$ at $3.4 \%\left(397,426 \mathrm{~g} \mathrm{KMnO}_{4}\right)$ was mixed in with $124,233.7 \mathrm{~kg}$ soil which yields a loading rate of $3.2 \mathrm{~g} \mathrm{KMnO}_{4} / \mathrm{kg}$ soil in $\mathrm{C} 2$. Therefore, the overlap regions have received an additional $3.2 \mathrm{~g} \mathrm{KMnO}_{4}$ per kg soil:

$3.2 \mathrm{~g} \mathrm{KMnO}_{4} / \mathrm{kg}$ soil $\times 37,270 \mathrm{~kg}$ soil $=119,227 \mathrm{~g} \mathrm{KMnO}_{4}$ $119,227 \mathrm{~g} \mathrm{KMnO}_{4}$ must be added to the $\mathrm{C} 1$ and $\mathrm{C} 3$ overlap regions to determine the total $\mathrm{KMnO}_{4}$ added:

$119,227 \mathrm{~g} \mathrm{KMnO}_{4}+135,663 \mathrm{~g} \mathrm{KMnO}_{4}$ in the $\mathrm{C} 1 / \mathrm{C} 2$ overlap region $=254,890 \mathrm{~g}$ total in the $\mathrm{C} 2 / \mathrm{C} 1$ overlap region 


\section{G-5}

$119,227 \mathrm{~g} \mathrm{KMnO}_{4}+222,502 \mathrm{~g} \mathrm{KMnO}_{4}$ in the $\mathrm{C} 1 / \mathrm{C} 3$ overlap region $=341,729 \mathrm{~g}$ total in the $\mathrm{C} 2 / \mathrm{C} 3$ overlap region

Loading rate for $\mathrm{C} 2$ calculated as follows:

$\mathrm{C} 2 / \mathrm{C} 1$ overlap region: $254,890 \mathrm{~g} \mathrm{KMnO}_{4} / 37,270 \mathrm{~kg}$ soil $=6.84 \mathrm{~g} \mathrm{KMnO}_{4} / \mathrm{kg}$ soil $\mathrm{C} 2 / \mathrm{C} 3$ overlap region: $341,729 \mathrm{~g} \mathrm{KMnO}_{4} / 37,270 \mathrm{~kg}$ soil $=9.17 \mathrm{~g} \mathrm{KMnO}_{4} / \mathrm{kg}$ soil $\mathrm{C} 2$ nonoverlap area is $3.2 \mathrm{~g} \mathrm{KMnO}_{4} / \mathrm{kg}$ soil

Weighted average loading rate for the $\mathrm{C} 2$ column: (30\%) $6.84 \mathrm{~g}+(30 \%) 9.17 \mathrm{~g}+$ $(40 \%) 3.2 \mathrm{~g}=6.1 \mathrm{~g} \mathrm{KMnO}_{4} / \mathrm{kg}$ soil 


\section{INTERNAL DISTRIBUTION}
1. B. Berven
2-6. S. R. Cline
7. J. H. Cushman
8 D. E. Fowler
9-13. F. G. Gardner
14. S. G. Hildebrand
15. G. K. Jacobs
16. P. Kanciruk
17-21. N. E. Korte
22. C. A. Little
23. J. M. Loar
24. R. Mann
25. T. E. Myrick
26. D. E. Reichle
27-31. R. L. Siegrist
32. D. S. Shriner

33-37. J. Strong-Gunderson

38-42. O.R. West

43. Central Research Library

44-46. ESD Library

47-48. Laboratory Records Dept.

49. Laboratory Records, ORNL-RC

\section{EXTERNAL DISTRIBUTION}

50. J. Baker, AlliedSignal, Inc., 2000 E. 95th Street, Kansas City, MO 64131

51. M. Broido, Director, Environmental Sciences Division, ER-74, Department of Energy, 19901 Germantown Road, Germantown, MD 20874

52. E. G. Cumesty, ORNL Site Manager, Department of Energy, Oak Ridge National Laboratory, P.O. Box 2008, Oak Ridge, TN 37831-6269

53. Michael C. MacCracken, Director, Office of the U.S. Global Change Research Program, Code YS-1, 300 E Street, SW, Washington, DC 20546

54. A. Patrinos, Associate Director, Office of Health and Environmental Research, ER-70, Department of Energy, 19901 Germantown Road, Germantown, MD 20874

55. Office of Assistant Manager for Energy Research and Development, U.S. Department of Energy Oak Ridge Operations, P.O. Box 2001, Oak Ridge, TN 37831-8600

55-57. Office of Scientific and Technical Information, P.O. Box 62, Oak Ridge, TN 37831 